\title{
ANÁLISE IN-SILICO DE INTEGRASES NO FITOPATÓGENO Xylella fastidiosa: DIVERSIDADE, SÍTIOS DE INTEGRAÇÃO E ASSOCIAÇÃO COM BACTERIÓFAGOS
}

\author{
ALESSANDRO DE MELLO VARANI
}

Tese (Doutorado) apresentada ao Programa

de Pós-Graduação Interunidades em Biotecnologia USP/ Instituto Butantan/ IPT, para obtenção do Título de Doutor em Biotecnologia.

São Paulo

2008 


\title{
ANÁLISE IN-SILICO DE INTEGRASES NO FITOPATÓGENO Xylella fastidiosa: DIVERSIDADE, SÍTIOS DE INTEGRAÇÃO E ASSOCIAÇÃO COM BACTERIÓFAGOS
}

\author{
ALESSANDRO DE MELLO VARANI
}

Tese (Doutorado) apresentada ao Programa de Pós-Graduação Interunidades em Biotecnologia USP/ Instituto Butantan/ IPT, para obtenção do Título de Doutor em Biotecnologia.

Área de concentração: Biotecnologia

Orientador:

Profa. Dra. Marie Anne Van-Sluys

São Paulo

2008 
DADOS DE CATALOGAÇÃO NA PUBLICAÇÃO (CIP)

Serviço de Biblioteca e Informação Biomédica do

Instituto de Ciências Biomédicas da Universidade de São Paulo

reprodução não autorizada pelo autor

\section{de Mello Varani, Alessandro.}

Análise in-silico de integrases no fitopatógeno Xylella fastidiosa: diversidade, sítios de integração e associação com bacteriófagos / Alessandro de Mello Varani. -- São Paulo, 2008.

Orientador: Marie Anne Van Sluys.

Tese (Doutorado) - Universidade de São Paulo. Instituto de Ciências Biomédicas. Programa de Pós-Graduação Interunidades em Biotecnologia USP/IPT/Instituto Butantan. Área de concentração: Biotecnologia. Linha de pesquisa: Genética de microorganismos.

Versão do título para o inglês: In silico analysis of integrases in the phytopathogen Xylella fastidiosa: diversity, integration sites and association with bacteriophages.

Descritores: 1. Bactérias fitopatogênica 2. Genomas 3. Fenômenos 4. Bacteriófagos I. Van Sluys, Marie-Anne II. Universidade de São Paulo. Instituto de Ciências Biomédicas. Programa de Pós-Graduação em Biotecnologia III. Título. 


\section{UNIVERSIDADE DE SAO PAULO \\ Programa de Pós-Graduação Interunidades em Biotecnologia}

Universidade de São Paulo, Instituto Butantan, Instituto de Pesquisas Tecnológicas

Candidato(a):

Título da Tese:

Orientador(a):
Alessandro de Mello Varani.

Análise in-silico de integrases no fitopatógeno Xylella fastidiosa: diversidade, sítios de integração e associação com bacteriófagos.

Marie Anne Van Sluys.

A Comissão Julgadora dos trabalhos de Defesa da Tese de Doutorado, em sessão pública realizada a .................., considerou

\section{( ) Aprovado(a) \\ ( ) Reprovado(a)}

$\begin{array}{ll}\text { Examinador(a): } & \text { Assinatura: } \\ & \text { Nome: ........ } \\ & \text { Instituição: .. } \\ \text { Examinador(a): } & \text { Assinatura: } \\ & \text { Nome: ........ } \\ & \text { Instituição: . } \\ \text { Examinador(a): } & \text { Assinatura: } \\ & \text { Nome: ......... } \\ & \text { Instituição: ... } \\ \text { Examinador(a): } & \text { Assinatura: } \\ & \text { Nome: ........ } \\ & \text { Instituição: ... }\end{array}$

Presidente: Assinatura:

Nome:

Instituição: 


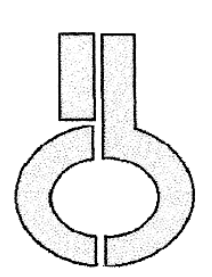

\section{CERTIFICADO DE ISENÇÃO}

Certificamos que o Protocolo CEP-ICB N ${ }^{\circ}$ 247/08, referente ao projeto intitulado: “Análise in-silico de proteínas com domínio integrase no fitopatógeno xylella fastidiosa: Diversidade, sítios de integração e associação com bacteriófagos" sob a responsabilidade de Alessandro de Mello Varani, foi analisado na presente data pela CEEA COMISSÃO DE ÉtiCA EM EXPERIMENTAÇÃO ANIMAL e pela CEPSH COMISSÃo DE Ética EM PESQUiSA COM SERES humanOS, tendo sido deliberado que o referido projeto não envolve manipulação animal ou humana que justifique uma aprovação quanto aos princípios éticos exigidos por ambas as Comissões.

São Paulo, 22 de abril de 2008.

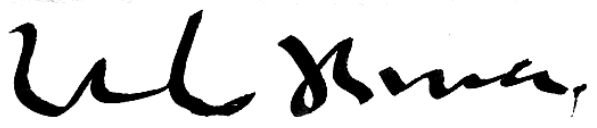

PROF. DR. WOTHAN TAVARES DE LIMA Coordenador da CEEA - ICB/USP
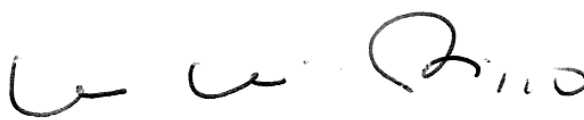

PROF. DR. LUIZ VICENTE RIZZO Coordenador da CEPsh - ICB/USP 


\section{DEDICATÓRIA}

Aos meus pais e irmão Obrigado por tudo! 


\section{AGRADECIMENTOS}

À Profa. Marie-Anne Van Sluys, pela orientação, apoio e paciência ao longo dos últimos cinco anos de trabalho e de excelente convivência profissional. Obrigado por ter me recebido em seu laboratório, e ter me fornecido a oportunidade de desenvolver este trabalho.

Às Profas. Magdalena Rossi, e Mariana Cabral de Oliveira pela ótima convivência profissional, amizade, conselhos e apoio em todas as fases de meu projeto.

À Profa. Cláudia Barros Monteiro-Vitorello, pelos conselhos científicos valiosos, e pela amizade.

À Profa. Ana Tereza Vasconcelos, por ter me recebido tão bem no LNCC e ter fornecido valiosa ajuda durante uma fase de desenvolvimento de meu projeto.

Aos atuais e antigos colegas de laboratório (GaTE/USP): Ana Paula Costa, Andrés, Breno, Bruno, Cíntia, Daniela Kajihara, Daniela Milstein, Douglas, Elis, Edgar, Érika, Fabiana, Guilherme, Hana, Jonas, Juliane Ishida, Juliana Nico, Leonor, Luiza, Marcelo, Maria Elisa, Marisa, Mayra, Myna, Nathalia, Nilo, Regina, Robson, Silvia, Úrsula, Vanessa, Vivian e Wanessa. Obrigado pela amizade, apoio e pelos anos de convivência, nunca me esquecerei de nenhum de vocês!

A toda equipe de bioinformática do LNCC, em especial ao Luiz Gonzaga, com a ajuda nos procedimentos de montagem de genomas; ao Rangel pela ajuda com as análises comparativas; e ao Roger por toda a ajuda em fazer as coisas funcionarem.

Ao Helder (Sinistro), por toda ajuda na análise dos dados de expressão gênica e pela amizade. Ao Paulo Cesar, pela amizade e convivência em diversas disciplinas da pós.

A Wa, por toda paciência e ajuda, muito obrigado!

Aos meus pais e irmão, obrigado por tudo!

A todos que contribuíram direta e indiretamente para realização deste trabalho, muito obrigado!!

Este trabalho foi realizado com o suporte financeiro da CAPES. 
"[...] estas são algumas das coisas de que átomos de hidrogênio são capazes, depois de 15 bilhões de anos de evolução do cosmos.

Esta frase soa como um mito épico, mas é simplesmente a descrição da evolução do cosmos revelada pela ciência de nossa época. E nós, nós que personificamos aqui os olhos, ouvidos, pensamentos e sentimentos do cosmos, começamos finalmente a investigar nossas origens [...]"

Carl Sagan - Cosmos, Episódio 13 - "Quem Pode Salvar a Terra?" 


\section{RESUMO}

Varani AM. Análise in-silico de integrases no fitopatógeno Xylella fastidiosa: diversidade, sítios de integração e associação com bacteriófagos [Tese de Doutorado]. São Paulo (Brasil): Instituto de Ciências Biomédicas da Universidade de São Paulo; 2008.

Os elementos genéticos móveis encontrados no genoma da bactéria Xylella fastidiosa (Xf) são representados principalmente por bacteriófagos (na forma de profagos inseridos no genoma) e ilhas genômicas. Em ambos os casos nota-se a presença de ORFs que codificam integrases. As integrases são responsáveis pelo processo de mobilização (integração e/ou excisão) destes elementos, através do mecanismo de recombinação sítio-específica. Bacteriófagos e ilhas genômicas estão associados a eventos de rearranjos genômicos e à aquisição e/ou interrupção de genes importantes para bactéria, tendo implicação direta na diversidade e organização genômica e, por conseqüência, na diferenciação entre linhagens. A extensão e o impacto desses eventos é o foco deste trabalho, através da análise in-silico das integrases e sua associação com regiões de profagos e ilhas genômicas, no genoma de quatro linhagens de Xf. Um total de 56 integrases, divididas em integrases de ilhas genômicas (que apresentam domínio INT-CP4) e integrases de fagos (que apresentam domínio de tirosina recombinase), foram identificadas, estando distribuídas em $60 \%$ dos casos na proximidade da região de término de replicação, local onde também se concentram a maioria dos rearranjos entre as linhagens. Oito tipos de tRNAs são identificados como alvo de integração. Estudos filogenéticos sugerem que as integrases de fagos de Xf estão associadas principalmente às integrases encontradas em bacteriófagos do tipo lambda. Analisando-se a composição de ORFs de cada região relacionada a profagos e ilhas genômicas, nota-se a presença de ORFs com provável função relacionada a patogenicidade e/ou virulência. Os dados aqui apresentados corroboram o papel das integrases e seus elementos genéticos móveis como agentes chaves no processo de diversidade e evolução da organização genômica entre as quatro linhagens de Xf.

Palavras-chave: Xylella fastidiosa; Bacteriófagos, Integrases, Transferência gênica lateral; Genômica comparativa 


\section{ABSTRACT}

Varani AM. In silico analysis of integrases in the phytopathogen Xylella fastidiosa: diversity, integration sites and association with bacteriophages [Ph.D. Thesis]. São Paulo (Brasil): Instituto de Ciências Biomédicas da Universidade de São Paulo; 2008.

The mobile genetic elements (MGEs) found in the genome of the bacterium Xylella fastidiosa (Xf) are mainly represented by bacteriophages (as prophages inserted into the genome) and genomic islands. In both cases they bear ORFs encoding integrases, proteins responsible for the process of mobilization (integration and/or excision) of the MGEs by the mechanism of site-specific recombination. Bacteriophages and genomic islands are associated with events of genomic rearrangements and acquisition and/or interruption of important genes for the bacteria, with direct involvement in the diversity and genomic organization and, consequently, in the differentiation between strains. The extent and impact of these events are the focus of this work, through in-silico analysis of integrases and their association with prophage regions and genomic islands in the genome of four strains of Xf. A total of 56 integrases, divided into integrases of genomic islands (with INT-CP4 domain) and integrases of phages (with tyrosine recombinase domain), have been identified and are distributed in $60 \%$ of cases near to the terminus of replication, where the majority of rearrangements between the strains occur. Eight types of tRNAs are identified as the integration site. Phylogenetic analysis suggests that phage integrases are mainly related to integrases found in lambda-like bacteriophages. Within the genomic islands and prophage regions, there are ORFs with putative function related to pathogenicity and/or virulence. The data here presented support the role of integrases and their associated MGEs as key players in the process of evolution and diversity of the genomic organization between the four strains of Xf.

Keywords: Xylella fastidiosa; Bacteriophages, Integrases, Lateral gene transfer; Comparative genomics 


\section{LISTA DE ABREVIATURAS E SIGLAS}

attB: Sítio de ligação/reconhecimento da bactéria,

attP: Sítio de ligação/reconhecimento do fago,

CDD: do inglês, Conserved Domain Database,

DR: do inglês, direct repeats; repetições diretas,

EGMs: elementos genéticos móveis,

FS/SCF: do inglês, frameshift / stop codon in frame,

HMM: do inglês, hidden markov models,

HQD: do inglês, high quality discrepancies,

ISs: do inglês, insertion sequence elements; Seqüências de Inserção,

IGs: ilhas genômicas,

IPs: ilhas de patogenicidade,

LGT: do inglês, lateral gene transfer,

LQD: do inglês, low quality discrepancies,

MGEs: do inglês, mobile genetic elements,

NCBI: do inglês, National Center for Biotechnology Information,

ORI: Origem de Replicação,

ORF: do inglês, open reading frame; quadro aberto de leitura,

PAI: do inglês, pathogenicity island; ilha de patogenicidade,

PDB: do inglês, Protein Data Base,

RTIs: repetições terminais invertidas,

RSE: Recombinação sítio específica,

TGL: transferência gênica lateral,

TIRs: do inglês, terminal inverted repeats,

Xf: Xylella fastidiosa,

Xf-AL: Xf linhagem Dixon,

Xf-CVC: Xf linhagem 9a5c, causadora da clorose variegada dos citros,

Xf-OL: Xf linhagem Ann1,

Xf-PD: Xf linhagem Temecula1, causadora do mal de Pierce. 


\section{LISTA DE FIGURAS}

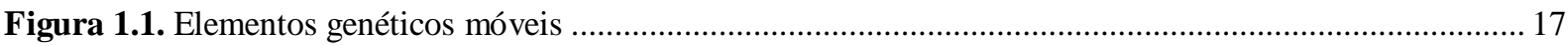

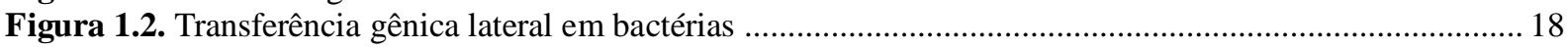

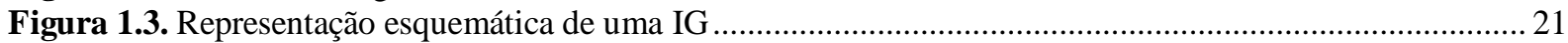

Figura 1.4. Representação esquemática do ciclo lítico e ciclo lisogênico do bacteriófago lambda .........................22

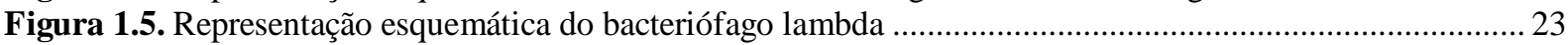

Figura 1.6. Modelo de integração e excisão do genoma do fago lamda ao cromossomo bacteriano...................... 26

Figura 1.7. Modalidades de eventos de transdução (generalizada e especializada) ...............................................2 27

Figura 1.8. Representação dos mecanismos de recombinação sítio-específica ...................................................... 28

Figura 1.9. Representação do mecanismo de recombinação das tirosinas recombinases ....................................... 31

Figura 1.10. Representação do mecanismo de recombinação das serinas recombinases ....................................... 31

Figura 1.11. Representação esquemática dos domínios catalíticos das integrases de fagos ....................................33

Figura 1.12. Estrutura 3D e modelo teórico de interação com DNA da integrase do fago lambda ........................33

Figura 1.13. Árvore de rRNA 16S, mostrando a posição do gênero Xylella dentro do grupo de Bactérias .......... 36

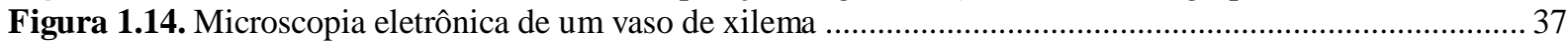

Figura 1.15. Fotografias ilustrativas dos sintomas identificados em plantas infectadas por $\mathrm{Xf}$........................... 38

Figura 1.16. Representação esquemática das regiões colineares e alinhamento entre Xf-CVC e Xf-PD.............. 41

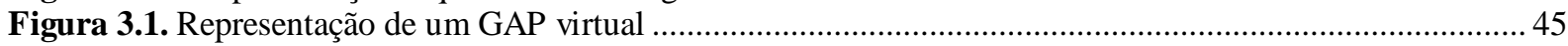

Figura 3.2. Representação de montagem colapsada devido à presença de repetições ........................................... 46

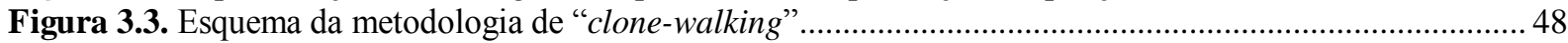

Figura 4.1. Distribuição das integrases de fagos ao longo dos cromossomos das linhagens de $\mathrm{Xf}$.......................57

Figura 4.2. Distribuição das integrases de fagos ao longo do cromossomo de cada linhagem de $\mathrm{Xf}$....................58

Figura 4.3. Classificação das integrases, computadas através de árvore de distância ........................................... 61

Figura 4.4. Análise de agrupamento das integrases pelo método de Network …………….................................. 62

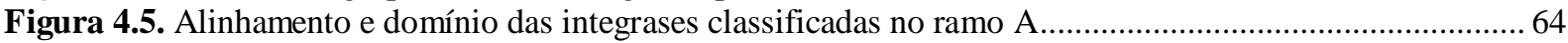

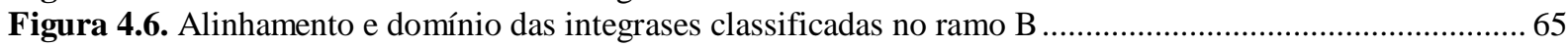

Figura 4.7. Alinhamento e domínio das integrases classificadas no ramo $C$....................................................... 66

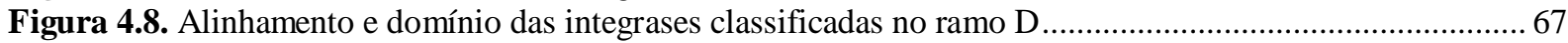

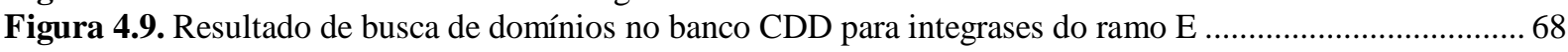

Figura 4.10. Resultado de busca de domínios no banco CDD para integrases do ramo E .................................... 68

Figura 4.11. Resultado de busca de domínios no banco CDD para integrases giCVC e giPD ............................... 69

Figura 4.12. Árvore de distância das integrases de Xf com 184 integrases de fagos .......................................... 72

Figura 4.13. Árvore de distância pelo método de neighbor-joining referente ao ramo I....................................... 74

Figura 4.14. Árvore de distância pelo método de neighbor-joining referente ao ramo II ...................................... 76

Figura 4.15. Árvore de distância pelo método de neighbor-joining referente ao ramo III ..................................... 77

Figura 4.16. Árvore de distância pelo método de neighbor-joining referente ao ramo IV .................................... 79

Figura 4.17. Árvore de distância das integrases de Xf com 84 ortólogos identificados por BLAST ..................... 83

Figura 4.18. Árvore de distância entre as integrases de IGs com 40 ortólogos .................................................... 85

Figura 4.19. Esquema das formas de ocorrência dos tRNAs no genoma de $\mathrm{Xf}$................................................... 89

Figura 4.20. Esquema de tRNA associado aos elementos xfp6 e xap9 ............................................................ 90

Figura 4.21. Esquema de tRNA associado aos elementos xfp2, xap1, xap4 e xap10 .........................................92

Figura 4.22. Esquema da região remanescente cvc-r4 ………………………………………….................. 93

Figura 4.23. Alinhamento pelo programa MUMmer entre os genomas das quatro linhagens de $X f$.................. 95

Figura 4.24. Representação comparativa entre as quatro linhagens de $X$. fastidiosa............................................. 96

Figura 4.25. Distribuição das ORFs em regiões de profagos .......................................................................... 99

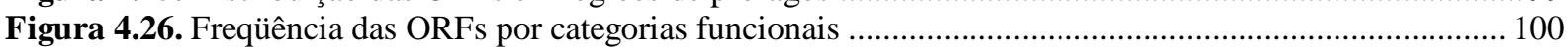

Figura 4.27. Frequiência de BBHs de ORFs estruturais associadas com famílias de fagos ................................. 107

Figura 4.28. Análise comparativa entre as regiões de profagos (A, B, C, D e E) ................................................ 109

Figura 4.29. Análise comparativa entre as regiões de profagos (1) ............................................................ 114

Figura 4.30. Análise comparativa entre as regiões de profagos (2) ............................................................. 115

Figura 4.31. Análise comparativa entre as regiões de profagos (3) ............................................................ 115

Figura 5.1. Hipótese de quebra com reconstituição do tRNA-ASN ................................................................. 126

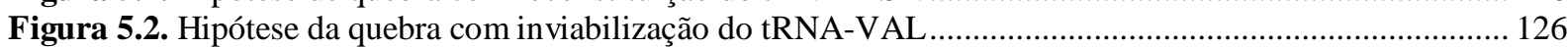

Figura 5.3. Estrutura primária e secundária do tRNA-GLY [GCC] não relacionado a EGMs ........................... 127

Figura 5.4. Distribuição dos tRNAs identificados em 81 fagos depositados no NCBI ...................................... 128

Figura 5.5. Mecanismo de recombinação e diversificação de fagos .................................................................. 133 


\section{LISTA DE TABELAS}

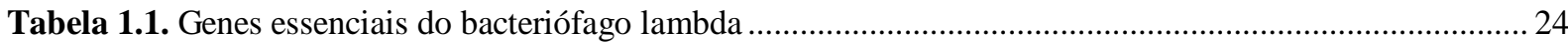

Tabela 1.2. Exemplo das duas famílias de recombinases sítio-específicas ....................................................29

Tabela 1.3. Principais características entre as integrases de fagos............................................................. 34

Tabela 1.4. Principais características genômicas identificadas nos genomas de Xf seqüenciados ...................... 39

Tabela 3.1. Domínios identificados para as tirosinas e serinas recombinases, pelo banco InterPro ...................49

Tabela 3.2. Domínios identificados para as tirosinas e serinas recombinases, pelo banco CDD........................50

Tabela 3.3. Categorias funcionais utilizadas pela ferramenta Phage-Navigator ........................................... 52

Tabela 4.1. Identificação de integrases de fagos e IGs nas quatro linhagens de Xf.......................................54

Tabela 4.2. Identificação de regiões de profagos e IGs nas quatro linhagens de Xf.......................................55

Tabela 4.3. Estruturas PDB relacionadas a integrases e recombinases de fagos e bactérias.............................. 70

Tabela 4.4. Estruturas PDB associadas às integrases de Xylella fastidiosa ................................................... 70

Tabela 4.5. Conjunto de BBHs formados a partir de análise pelo phage-navigator-comparative...................... 71

Tabela 4.6. Gêneros de fagos que apresentam integrases associadas às integrases de Xf ...............................73

Tabela 4.7. Posicionamento e localização dos tRNAs ao longo do cromossomo, nas quatro linhagens de $X f$.....87

Tabela 4.8. tRNAs e correlação como sítio de inserção para regiões de profagos e IGs ................................... 88

Tabela 4.9. Associação dos tRNAs com regiões de profagos e IGs ........................................................... 89

Tabela 4.10. Conteúdo e freqüência das ORFs das regiões de profagos e IGs ............................................. 101

Tabela 4.11. Conteúdo e freqüência das ORFs consideradas específicas/exclusivas ......................................102

Tabela 4.12. Toxinas e anti-toxinas identificadas nas regiões de profagos ................................................ 105

Tabela 4.13. Regiões de profagos candidatas a serem consideradas fagos completos................................... 106

Tabela 4.14. Posicionamento das regiões de profagos em relação ao contexto genômico ................................. 108

Tabela 5.1. Número de ORFs específicas para cada linhagem e a qual região relacionada a fago pertence ....... 120

Tabela 5.2. Correlação entre as formas de integrases identificadas em Xf e regiões de profagos .....................121

Tabela 5.3. Anti-códons do tRNA-GLY encontrado no genoma de Xf .................................................... 125

Tabela 5.4. Lista dos fagos que apresentam tRNA-Gly no genoma ............................................................ 128

Tabela 5.5. Regiões de profagos com ORFs relacionadas à virulência e patogenicidade................................ 131

Tabela 5.6. Compilação dos resultados referente às integrases de fagos ........................................................ 134

Tabela 5.7. Compilação dos resultados referente às integrases de IGs ..................................................... 134 


\section{SUMÁRIO}

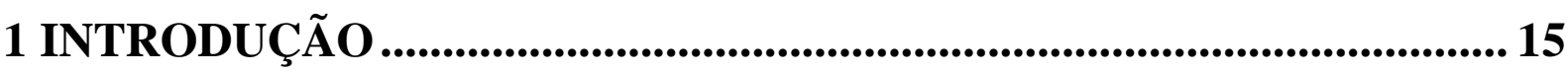

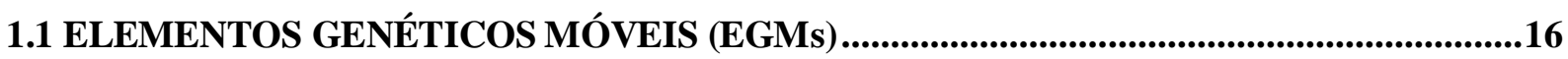

1.2 TRANSFERÊNCIA GÊNICA LATERAL EM BACTÉRIA...................................................18

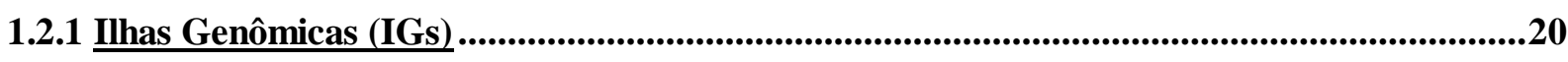

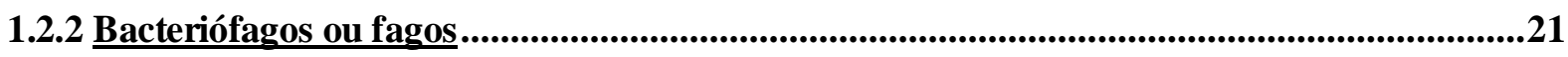

1.3 RECOMBINAÇÃO SÍTIO-ESPECÍFICA E A FAMÍLIA DAS RECOMBINASES ..............27

1.3.1 Tirosinas Recombinases ...................................................................................................................29

1.3.2 Serinas Recombinases ......................................................................................................................30

1.3.3 Integrases de fagos ..............................................................................................................................32

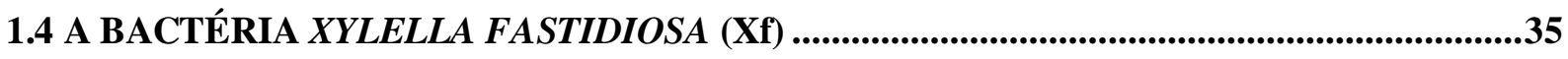

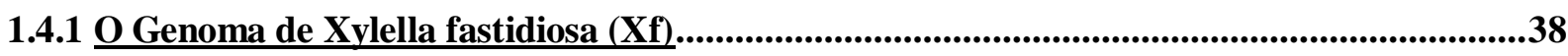

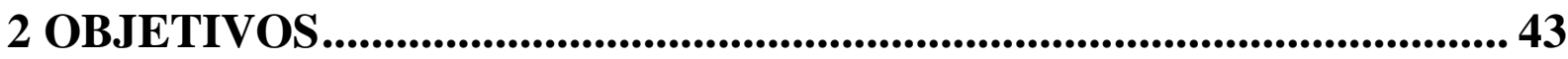

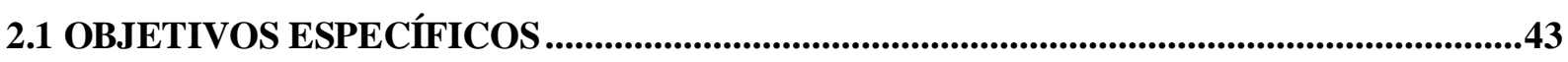

3 MATERIAIS E MÉTODOS ........................................................................ 46

3.1 MONTAGEM DE REgIÕES RELACIONADAS A PROFAGOS NA MOLÉCULA

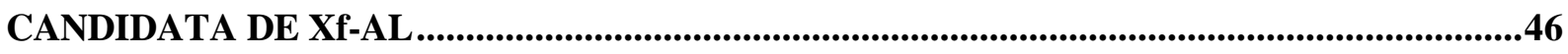

3.2 CARACTERIZAÇÃO DAS INTEGRASES DE PROFAgOS: DISTRIBUIÇÃO, CLASSIFICAÇÃO E DOMÍNIO CATALÍTICO ...........................................................48

3.3 FERRAMENTAS "PHAGE NAVIGATOR" E "PHAGE NAVIGATOR COMPARATIVE" E O BANCO DE DADOS “INTEGRASE_DB”......................................51

4 RESULTADOS.......................................................................53

4.1 IDENTIFICAÇÃO DO NÚMERO, ASSOCIAÇÃO E DISTRIBUIÇÃO DAS INTEGRASES DE PROFAGOS

4.2 CLASSIFICAÇÃO E RELAÇÕES ENTRE AS INTEGRASES: ANÁLISE DO DOMÍNIO CATALÍTICO

4.2.1 Análise do Domínio Catalítico: Famílias Serina ou Tirosina Recombinases ........................63

A. Integrases de fagos associadas a tirosinas recombinases (Ramos $A, B, C$ e D)..............................64

B. Integrases de fagos associadas a serinas recombinases (Ramo E) ...............................................67

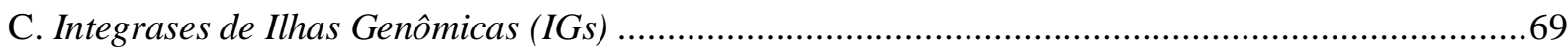

4.2.2 Domínios Catalíticos Associados ao PDB (Protein Data Bank) ..............................................69 
4.3 ASSOCIAÇÃO DAS INTEGRASES DE Xf COM BACTERIÓFAGOS.................................71

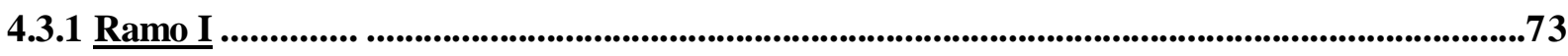

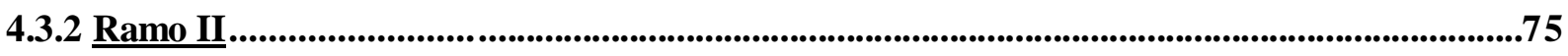

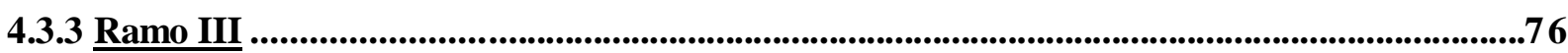

4.3.4 Ramo IV

4.4 ASSOCIAÇÃO DAS INTEGRASES DE Xf COM BACTÉRIAS....................................82

4.5 SÍTIOS DE INSERÇÃO DE INTEGRASES DE FAGOS ASSOCIADOS A tRNAS .............86 4.6 REARRANJOS GENÔMICOS E MAPA GENÔMICO COMPARATIVO ENTRE AS

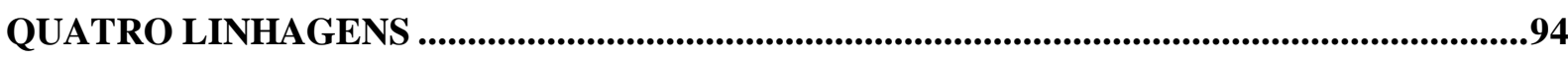

4.7 ANÁLISE DO CONTEÚDO GÊNICO PREDITO NAS REGIÕES RELACIONADAS A

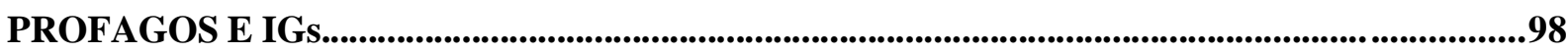
4.8 ANÁLISE COMPARATIVA DAS REGIÕES RELACIONADAS A PROFAGOS .............108

5 DISCUSSÃO.

5.1 ASSOCIAÇÃO DOS FAgOS E IGs NA EVOLUÇÃO ESTRUTURAL DO

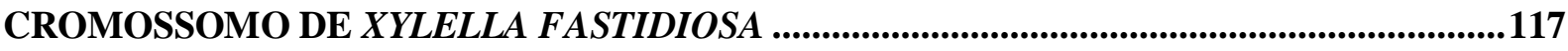

5.2 DIVERSIDADE DAS INTEGRASES: SÍTIOS DE INSERÇÃO E EGMS ASSOCIADOS .121

5.2.1 Integrases de Fagos .........................................................................................................................121

5.2.2 Integrases de Ilhas Genômicas ...........................................................................................129

5.3 REGIÕES RELACIONADAS A PROFAGOS E IGs: PROVÁVEL RELAÇÃO COM A

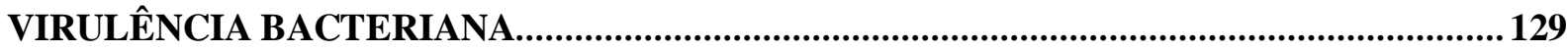

5.4 DIVERSIDADE DAS REGIÕES RELACIONADAS A PROFAGOS: ORIGEM E

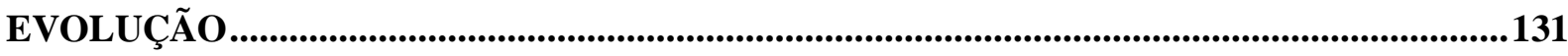

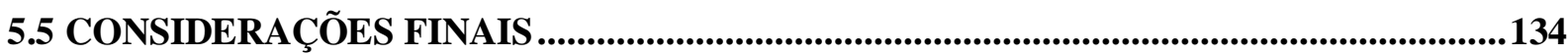

6 PERSPECTIVAS ........................................................................... 136

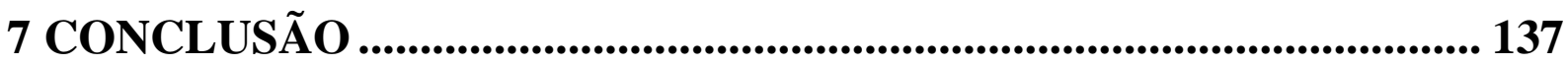

REFERÊNCIAS BIBLIOGRÁFICAS ...................................................... 138

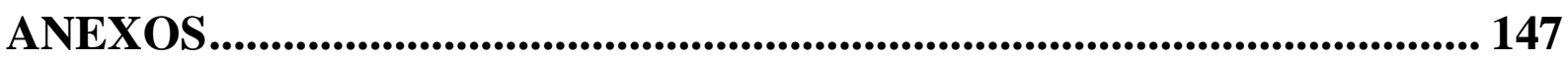

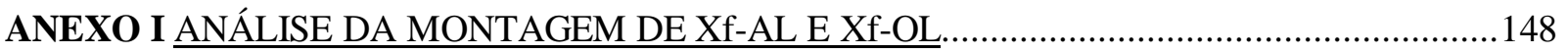

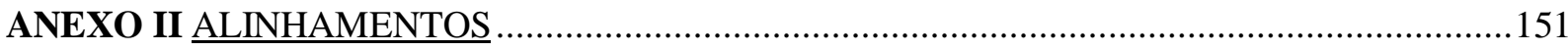

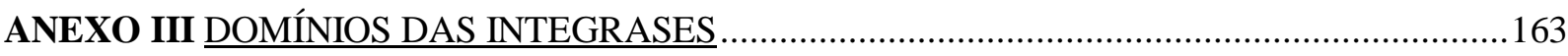

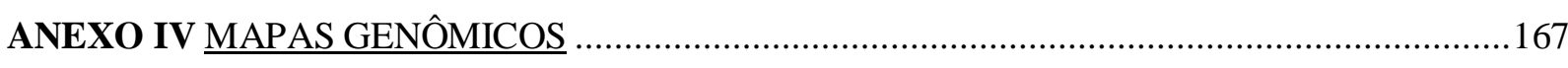

ANEXO V MANUSCRITO: Xylella fastidiosa prophage-like regions study reveals their origin, dynamics and their association to genome differentiation 


\section{INTRODUÇÃO}

Em razão do tamanho reduzido dos genomas procarióticos, que geralmente apresentam, salvo raras exceções, um tamanho médio menor que $5 \mathrm{Mb}$, centenas de genomas completos de várias espécies e cepas bacterianas foram publicados na última década. Atualmente (e esse número aumenta dia-a-dia), há mais de 650 genomas de bactérias publicados e quase 500 em processo de seqüenciamento (fonte: NCBI - Microbial Genomes Resources). Como resultado desse imenso volume de informação disponível, houve um avanço significativo na compreensão de temas importantes, como diversidade bacteriana, elementos genéticos móveis (EGMs) e processos de transferência gênica lateral (TGL) (Binnewies et al., 2006).

A ação dos EGMs em genomas foi constatada primeiramente por Barbara McClintock, em 1950, analisando a atividade de transposons em milho (ainda que naquela época os mecanismos que atuavam nas mudanças genéticas observadas não fossem completamente conhecidos). Evidências de processos de transferência gênica entre organismos também remontam de décadas atrás: em 1975, Falkow descreveu como a resistência a antibióticos em bactérias podia ser mediada por genes presentes em plasmídeos. No entanto, ambos processos sempre foram considerados mais como exceção do que regra, no estudo da evolução procariótica.

Atualmente, tal panorama mudou drasticamente, principalmente após a chamada "revolução genômica". Devido aos diversos avanços científicos decorrentes do desenvolvimento de técnicas moleculares e da análise do imenso volume de dados provenientes dos genomas seqüenciados, já foram descritos diversos tipos de EGMs que apresentam as mais diversas particularidades biológicas, e foi possível determinar o seu papel como mediadores de eventos de transferência gênica em procariotos. Tais eventos de TGL são tidos, hoje em dia, como responsáveis pela geração de grande parte da diversidade genética bacteriana (Dobrindt et al., 2004).

Assim, ao longo das últimas décadas, estudos focados em evolução bacteriana, principalmente nos processos mediados por elementos exógenos (como EGMs ou genes provenientes de outros organismos), presenciaram grandes avanços, impulsionados pela publicação (numa taxa exponencial) de genomas completos a partir da segunda metade da década de 90, e atualmente constituem-se em um campo de estudo essencial para a compreensão dos processos moleculares e evolutivos atuantes nos genomas bacterianos (Binnewies et al., 2006). 


\subsection{ELEMENTOS GENÉTICOS MÓVEIS (EGMs)}

Os elementos genéticos móveis (EGMs, ou MGEs, do inglês mobile genetic elements) são elementos genéticos cuja principal característica é sua capacidade de mobilização dentro de um genoma ou ainda entre genomas distintos, numa ação mediada por proteínas codificadas pelo próprio elemento. Em função dessa atividade móvel, eles não são tidos como parte integrante do "genoma central" de um organismo; ao contrário, eles são principalmente considerados como DNA exógeno, adquiridos por processos de transferência gênica lateral de outros organismos doadores (procariotos ou até mesmo eucariotos) (Binnewies et al., 2006; Frost et al., 2005).

Genomas bacterianos são compactos e carregam apenas genes responsáveis pela sobrevivência e reprodução. A reprodução é garantida por um conjunto de genes envolvidos em funções básicas, tais como metabolismo energético e processamento da informação genética; tais funções dependem da interação de um grupo de proteínas codificadas por estes genes, que correspondem ao que é definido como "componentes essenciais de um genoma mínimo", caracterizando a porção "estável" do genoma, através da qual é possível traçar sua história evolutiva, por exemplo (Liu et al., 1999; Monteiro-Vitorello et al., 2005). A sobrevivência, por outro lado, é garantida por um conjunto de genes relacionados à capacidade de adaptação às mudanças no meio ambiente; este conjunto de genes, muitas vezes, é proveniente de outros organismos, sendo introduzidos no genoma por eventos de transferência gênica lateral, mediados por EGMs, promovendo assim a diversidade genética necessária para sua adaptação e sobrevivência ao meio ambiente. As funções relacionadas à sobrevivência estão ligadas a genes específicos para adaptação ao meio, fatores associados à patogenicidade ou relacionados à interação bactéria-hospedeiro, caracterizando desta forma a porção “instável” do genoma, o alvo de estudos no campo dos EGMs (Figura 1.1) (Monteiro-Vitorello et al., 2005; Sullivan e Ronson, 1998; Wong e Golding et al., 2003).

Os EGMs encontrados em bactérias são representados principalmente por plasmídeos, integrons, transposons, bacteriófagos e ilhas genômicas (IGs). A principal característica estrutural encontrada nos EGMs é a presença de segmentos de DNA que codificam enzimas com atividade recombinase, isto é, responsáveis pela sua inserção no cromossomo (Frost et al., 2005). 


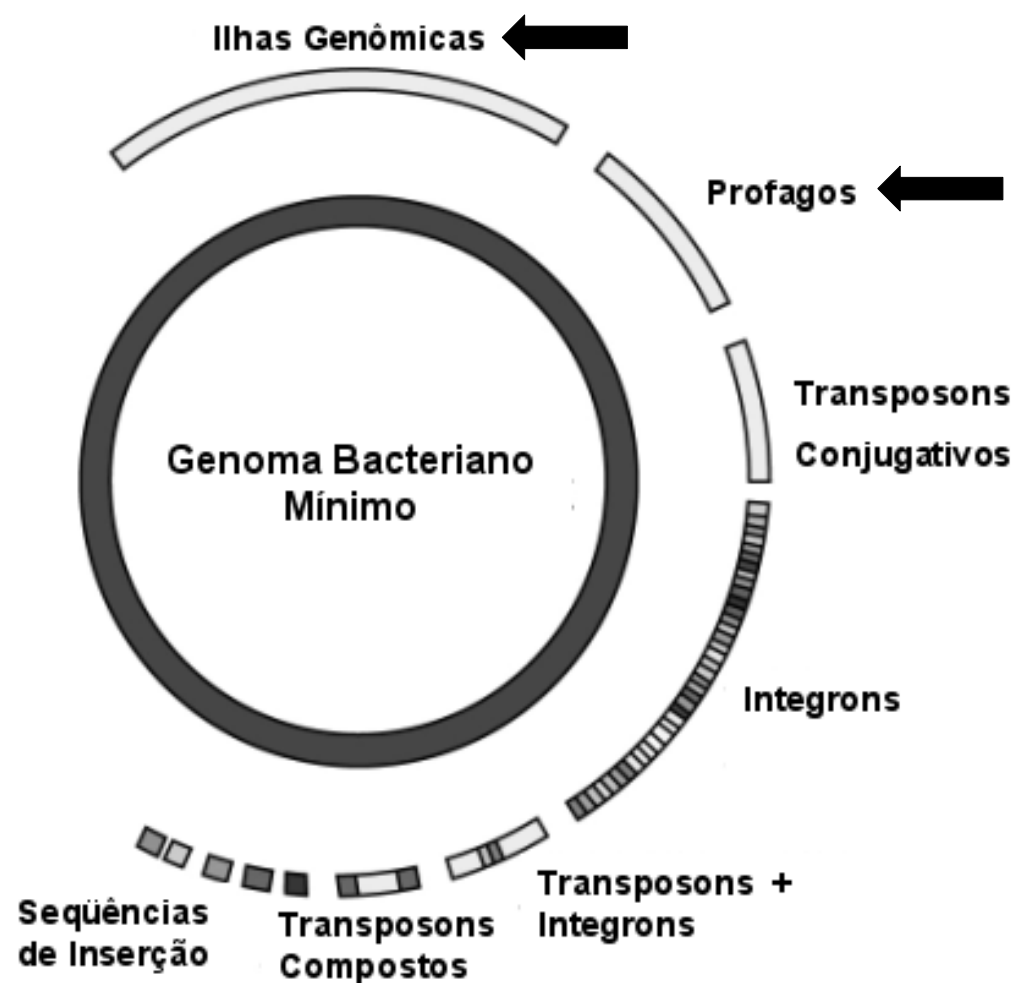

Figura 1.1. Elementos genéticos móveis. Ilustração esquemática da porção “estável” (Genoma Bacteriano Mínimo) e porção "variável" (ilhas genômicas, profagos, transposons e integrons) de um genoma bacteriano. As setas indicam os principais EGMs encontrados na bactéria Xylella fastidiosa. Obs.: plasmídeos não estão representados nesta figura (Adaptado de Michael Chandler, http://www-lmgm.biotoul.fr/ equipes/grpchand/).

Os plasmídeos são segmentos de DNA, usualmente circulares, que podem tanto se manter em uma forma extra-cromossomal, com capacidade auto-replicativa, como podem se inserir no cromossomo hospedeiro. Os integrons são elementos que apresentam uma proteína recombinase sítio-específica e um sítio de reconhecimento adjacente, contendo genes conhecidos como insertos, que serão expressos por um promotor localizado a jusante (downstream) dos genes; esses elementos estão freqüentemente associados à aquisição de resistência de antibióticos pela bactéria.

Os transposons são seqüências de DNA que apresentam a capacidade de se transporem dentro do genoma, pela ação direta de uma transposase. Eles estão divididos em várias categorias, todas apresentando repetições terminais invertidas (RTIs, ou TIRs, do inglês terminal inverted repeats), que são o alvo para a clivagem pela transposase durante a reação de transposição. Os elementos do tipo IS (do inglês insertion sequence elements) são transposons consistindo em geral de apenas um gene que codifica para uma transposase. Transposons

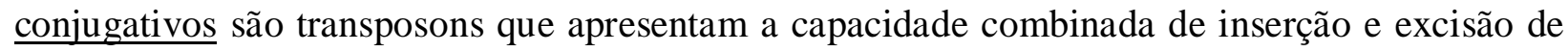
um cromossomo bacteriano, assim como a capacidade de serem propagados como um plasmídeo e portanto serem transferidos por conjugação entre bactérias através do contato direto entre elas. 
Bacteriófagos são vírus que infectam bactérias, atuando como veículos de transferência de segmentos de DNA entre bactérias de espécies distintas (através do processo de transdução). As ilhas genômicas são grandes regiões cromossômicas que geralmente carregam atributos de virulência, patogenicidade ou adaptação, e que podem ser transferidas entre bactérias, estando presentes em certos gêneros de bactérias e ausentes na maioria de suas linhagens próximas (Dobrindt et al., 2004).

\subsection{TRANSFERÊNCIA GÊNICA LATERAL EM BACTÉRIAS}

Por definição, transferência gênica lateral (TGL, ou LGT, do inglês lateral gene transfer) é o nome que designa processos envolvendo trocas de DNA entre organismos de espécies diferentes, mesmo entre linhagens evolutivamente distantes, em contraposição à herança clonal, onde os genes são passados entre gerações por processos de simples divisão celular (Eisen, 2000). Três são os mecanismos que garantem o intercâmbio de material genético entre bactérias: transformação, transdução e conjugação (Figura 1.2) (Frost et al., 2005; Furuya e Lowy, 2006).

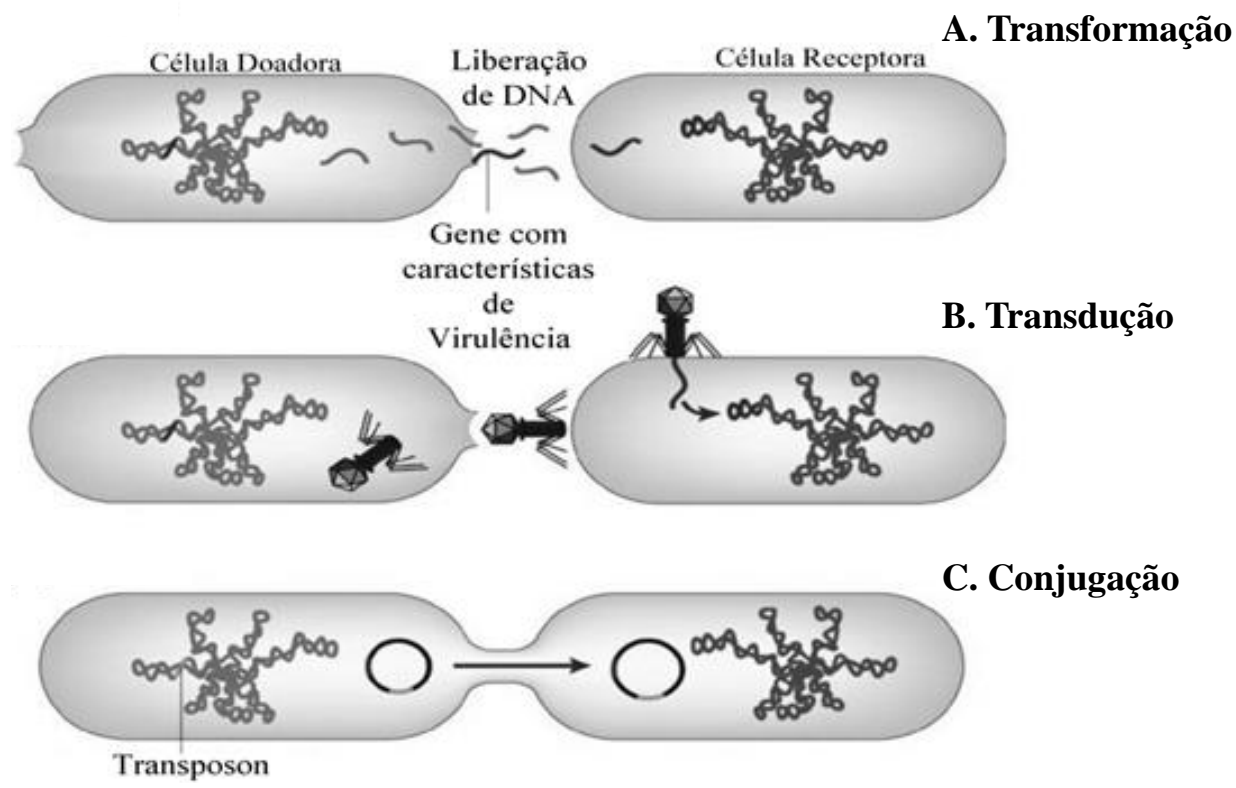

Figura 1.2. Transferência gênica lateral em bactérias. Ilustração dos três mecanismos de TGL em bactérias. A, transformação; B, transdução e C, conjugação (Adaptado de Furuya e Lowy, 2006).

A transformação é um mecanismo que envolve o intercâmbio de segmentos de DNA liberados pelo processo de lise celular entre uma célula doadora e uma célula receptora capaz de 
captar estes segmentos de DNA liberados no meio. Foi o primeiro mecanismo de TGL descrito em células procariontes, sendo observado pela primeira vez em 1928 por Frederick Griffith, sendo que somente em 1944 a molécula de DNA foi descrita como responsável por este processo (Avery et al., 1944; Ottolenghi e Macleod, 1963). É um processo que não exige, em termos espaciais-temporais, a presença simultânea das células doadora e receptora no meio, sendo que por esta razão apresenta potencial de transmitir segmentos de DNA entre microorganismos filogeneticamente distantes (Furuya e Lowy, 2006).

O processo de transdução é intermediado por bacteriófagos ou fagos, e dependente de um processo de infecção celular no qual ocorre um mecanismo de reconhecimento entre a célula a ser infectada e o fago. Apesar dos fagos infectarem um grande grupo de hospedeiros, podendo assim facilitar a transferência de material genético entre organismos distantes filogeneticamente, isso de fato não ocorre, devido ao estreito espectro de infecção apresentado pela maioria (Droge et al., 1998).

O processo de conjugação requer o contato direto entre a célula doadora e a célula receptora, e é característico dos mecanismos de propagação de plasmídeos capazes de realizar sua replicação e mobilização autônoma no cromossomo hospedeiro. Este processo envolve a formação de uma estrutura tubular, denominada pilus, codificada pelo plasmídeo (ou cromossomo) da célula doadora. Esta estrutura tem a função de ligar a célula receptora e a doadora a fim de permitir a transferência de segmentos de DNA entre as células de bactérias, plantas e fungos (Droge et al., 1998; Frost et al., 2005).

Nos três mecanismos de TGL, há a possibilidade de que genes relacionados à virulência e patogenicidade sejam integrados no cromossomo ou plasmídeos da célula receptora (Furuya e Lowy, 2006). Um exemplo é a aquisição do gene que codifica para isoleucina-tRNA sintetase, relacionado à resistência a antibióticos, por diversas espécies bacterianas, a partir de um doador eucarionte (Koonin et al., 2001). Portanto, os elementos genéticos mediadores de processos de TGL podem ser considerados como agentes chave na evolução de genomas bacterianos (Williams, 2002).

Devido à promiscuidade de intercâmbio de segmentos de DNA entre organismos filogeneticamente próximos e distantes, o mecanismo de TGL é tido como responsável por grande parte das similaridades e diferenças genômicas observadas entre os microorganismos, e muitos trabalhos exploram o seu papel inclusive no surgimento de novas espécies procarióticas (Campbell, 2000; Ochman et al., 2005). Alguns autores consideram os eventos de transferência lateral mais como o padrão do que a exceção em organismos procariontes, em razão da grande proporção de segmentos de DNA com características atípicas encontrados nos genomas de bactérias (Eisen, 2000; Gogarten et al., 2002; Ochman et al., 2000). 
Os principais EGMs identificados no genoma da bactéria Xylella fastidiosa são representados por bacteriófagos e ilhas genômicas (IGs); ambos são dependentes da presença de genes que codificam uma proteína recombinase sítio-específica responsável pela sua integração no genoma. A esta proteína recombinase sítio-específica é atribuído o nome de integrase quando associada às IGs e integrase de fagos quando associadas aos fagos (Groth e Calos, 2004; Hacker e Carniel, 2001; Simpson et al., 2000).

\subsubsection{Ilhas Genômicas (IGs)}

As ilhas genômicas (IGs) são EGMs presentes no genoma de bactérias que apresentam um conjunto de genes flexível em sua constituição, ligados geralmente com atributos de patogenicidade e virulência ou adaptação da bactéria ao meio. As características normalmente associadas às ilhas incluem: (i) presença no genoma de várias espécies bacterianas, porém ausentes no genoma de espécies ou linhagens próximas; (ii) estruturalmente, apresentam em média de 10 a 200 quilobases $(\mathrm{kb}$ ) (ainda que pequenos insertos de 1 a $10 \mathrm{~kb}$ possam ser encontrados, denominados "genomic islets"); (iii) apresentam divergência no conteúdo GC e no uso de códons, quando comparadas ao restante do genoma; (iv) são flanqueadas por repetições diretas (DR), geradas após integração no genoma do organismo receptor; (v) em 75\% das ocorrências, as IGs estão associadas com sítios de tRNAs, que atuam como alvo para integração; (vi) apresentam ORFs que podem codificar para proteínas associadas a EGMs, como por exemplo genes de bacteriófagos, transposases, integrases, sequiências de inserção e origem de replicação (ORI); (vii) são regiões instáveis, podendo ocorrer sua deleção via as DR presentes em suas bordas, através de ISs ou via recombinação homóloga (Hacker e Carniel, 2001; Hacker e Kaper, 2000). São identificadas através de determinação in-silico de composição nucleotídica atípica, inferências filogenéticas e presença de genes relacionados à mobilidade (recombinases/integrases) e tRNAs (Hsiao et al., 2003; Lima et al., 2005). A figura 1.3 mostra a representação esquemática de uma ilha genômica.

As ilhas genômicas podem ser classificadas de acordo com as vantagens que agregam à bactéria, sendo subdivididas em: (a) ilhas adaptativas (fitness islands): possuem genes cujos produtos promovem um aumento na adaptação do organismo recipiente ao meio, incluindo aumento na sobrevivência, dispersão e transmissão do organismo dentro de um nicho ecológico específico; (b) ilhas de patogenicidade (IPs): possuem genes cujos produtos contribuem para virulência da bactéria, como por exemplo toxinas; (c) ilhas de simbiose: possuem genes 
relacionados a processos de interações simbióticas com outros organismos; (d) ilhas de resistência: possuem genes responsáveis pela degradação de antibióticos ou outros compostos tóxicos para a célula (Hentschel et al., 2001).
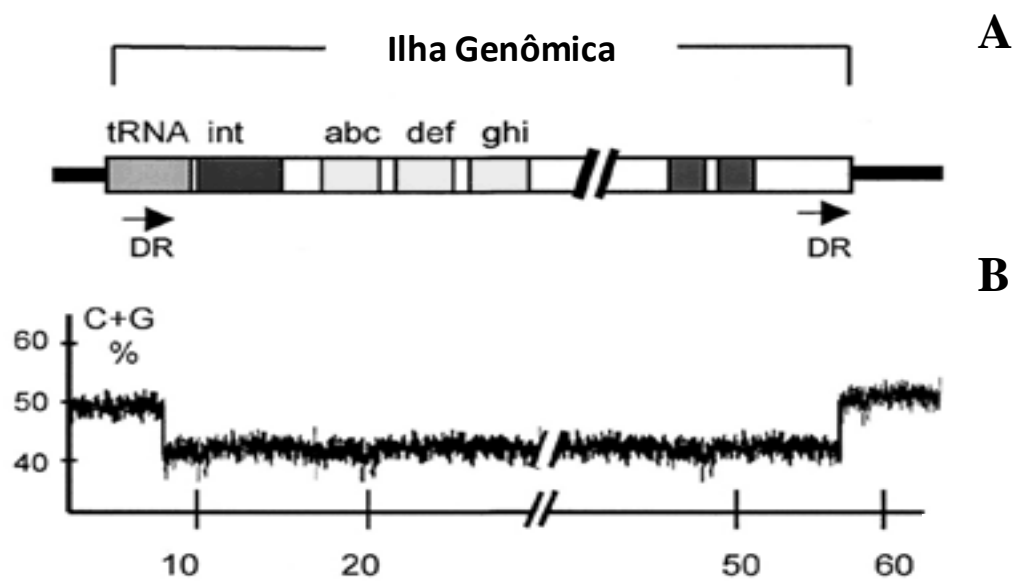

Figura 1.3. Representação esquemática de uma IG. A, IG inserida no cromossomo bacteriano, flanqueada por repetições diretas (DR) e um tRNA utilizado como alvo preferencial de inserção, e contendo a integrase e vários genes relacionados a patogenicidade e virulência. B, Freqüência GC da região da ilha genômica, apontando a diferença com relação ao cromossomo bacteriano. Abreviações: int, integrase; abc, def, ghi genes com funções específicas; (extraído e adaptado de Hacker e Carniel, 2001).

\subsubsection{Bacteriófagos ou fagos}

Bacteriófagos ou fagos designam um grupo específico de vírus que infectam bactérias, utilizando a maquinaria celular das mesmas para produção de novas partículas infecciosas (Groth e Calos, 2004). Os fagos foram as primeiras entidades biológicas utilizadas em pesquisas na área de biologia molecular e genômica (Fiers et al., 1976; Sanger et al., 1982), sendo que atualmente apresentam potencial para aplicação biotecnológica, como por exemplo na terapia antibacteriana e nanotecnologia (Merril et al., 2003; Zhang, 2003). São considerados como as entidades biológicas de vida livre mais abundante $\left(\sim 10^{30}\right.$ partículas) e com replicação mais rápida $\left(\sim 10^{25}\right.$ infecções por segundo) presentes na biosfera (Frost et al., 2005; Rohwer e Edwards, 2002).

O genoma dos fagos pode ser composto por uma molécula de DNA ou RNA de simples-fita ou dupla-fita, podendo atingir o tamanho de várias centenas de quilobases, codificando proteínas para a replicação e montagem de uma nova partícula viral. O genoma é protegido por um envoltório protéico, cujas proteínas são codificadas pelo próprio genoma do fago, denominado capsídeo (Frost et al., 2005). 
Os fagos apresentam diversos ciclos de vida: lítico, lisogênico e infecção crônica. No

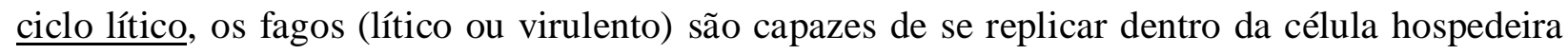
provocando a lise; para isso, redirecionam o metabolismo do hospedeiro para a produção de novos fagos. No ciclo lisogênico, o genoma do fago (temperado ou lisogênico) normalmente permanece no hospedeiro em um estágio inativo/dormente (profago), e se replica junto com o genoma do hospedeiro, até que o ciclo lítico seja induzido. A "decisão lisogênica", de estabelecer ou não um estado de profago, é feita pelo fago temperado após a infecção. Um fago temperado pode, por exemplo, se tornar virulento, devido a alterações nas condições fisiológicas do meio na qual a bactéria estiver presente ou por fatores físicos, como por exemplo, exposição à luz ultravioleta (UV) (Lwoff, 1953). Uma infecção crônica ocorre quando uma célula é infectada e a progênie do fago é constantemente liberada por extrusão ou brotamento, sem, no entanto, ocorrer lise celular. A figura 1.4 ilustra o ciclo lítico e lisogênico do fago lambda.

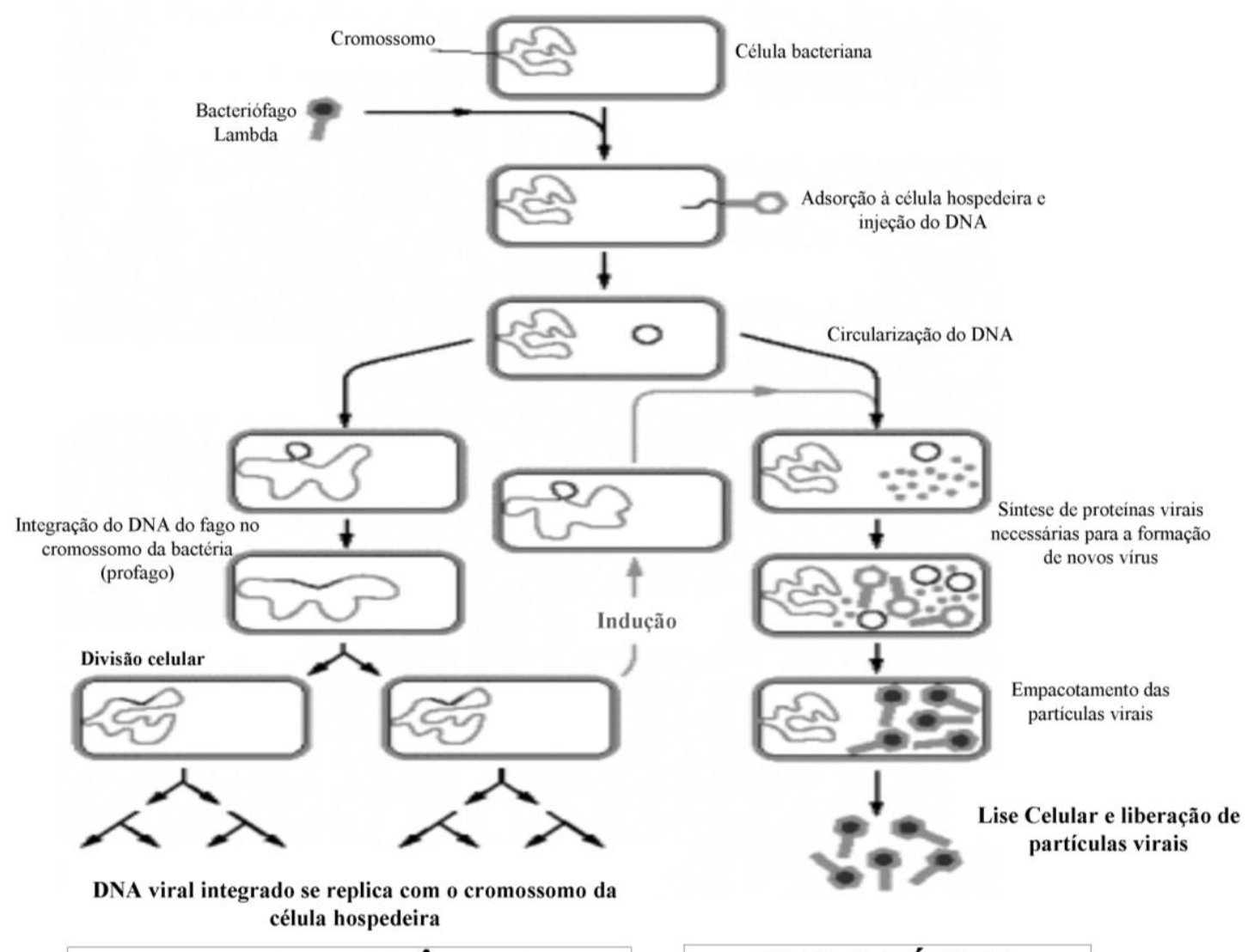

CICLO LISOGÊNICO

CICLO LÍTICO

Figura 1.4. Representação esquemática do ciclo lítico e ciclo lisogênico do bacteriófago lambda (Adaptado de Alberts et al., 2002). 
O bacteriófago lambda é um fago temperado que infecta a bactéria Escherichia coli, sendo um dos mais estudados na literatura. O fago lambda foi descoberto pelo pesquisador Esther Lederberg em 1951, e seu genoma foi completamente seqüenciado no início da década de 80; apresenta DNA dupla-fita, sem estágio de RNA, com tamanho de $48 \mathrm{~kb}$, codificando 71 proteínas (Sanger et al., 1982). Atualmente, existem mais de 450 genomas de fagos completamente seqüenciados (http://www.ncbi.nlm.nih.gov). A representação esquemática da estrutura e do genoma do fago lambda é apresentada na figura 1.5.

\section{Fago Lambda ( $\phi \lambda)$}

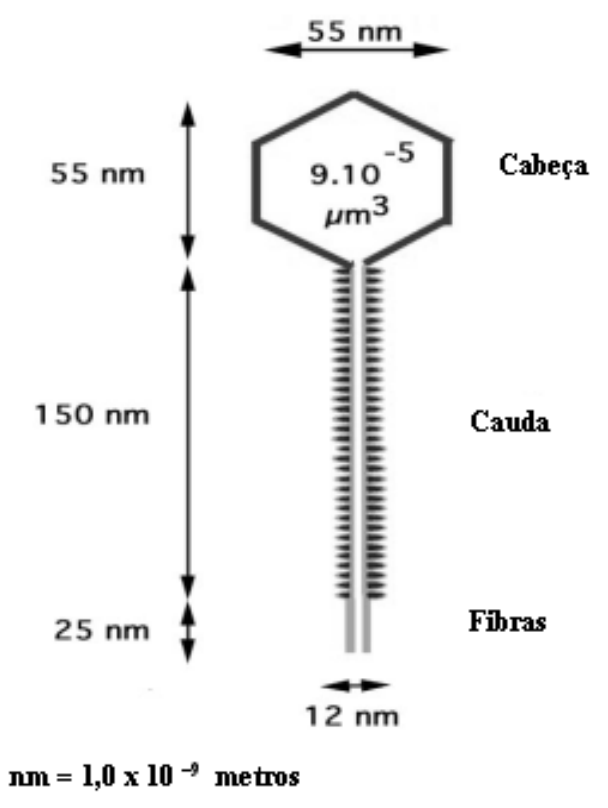

A 
O genoma do fago lambda possui tanto genes do ciclo lítico como genes do ciclo lisogênico; ambos compõem o conjunto de genes essenciais para fagos (Tabela 1.1). Os genes do ciclo lítico estão relacionados à regulação da expressão dos genes do próprio fago, replicação do genoma viral, componentes estruturais, montagem da partícula viral e lise celular, que ocasionam a liberação de fagos no meio. No ciclo lisogênico, em linhas gerais, apenas é necessária a expressão de dois grupos de genes, responsáveis pela integração do genoma do fago ao genoma da bactéria hospedeira: o primeiro está relacionado à atividade de regulação do fago entre ciclo lisogênico e lítico; e o segundo relacionado à integração do genoma do fago ao cromossomo bacteriano (Casjens, 2003).

Tabela 1.1. Genes essenciais do bacteriófago lambda *

\begin{tabular}{|c|c|c|}
\hline Papel & Gene(s) & Função \\
\hline RECOMBINAÇÃO & $\begin{array}{l}\text {-integrase (Int) } \\
\text {-Exciosinase (Xis) }\end{array}$ & $\begin{array}{l}\text {-Integrase, responsável pela integração/excisão do DNA do fago. } \\
\text {-Exciosinase, reguladora da atividade de int, e responsável pela } \\
\text { atividade de excisão do genoma do fago. }\end{array}$ \\
\hline $\begin{array}{l}\text { REGULAÇÃO } \\
\text { ENTRE O CICLO } \\
\text { LÍTICO E } \\
\text { LISOGENICO }\end{array}$ & $\begin{array}{l}-\mathrm{cI} \\
\text { - cro } \\
\text { - cII }\end{array}$ & $\begin{array}{l}\text { - Proteína de ligação. Protege cII da degradação por proteases do } \\
\text { hospedeiro. } \\
\text { - Reguladora da transcrição do genoma do fago. Proteína de ligação } \\
\text { ao RNA e cofator para RNA polimerase. } \\
\text { - Repressor, responsável pelo ciclo lisogênico. Em baixas } \\
\text { concentrações, inibe o promotor de cro. } \\
\text { - Anti-repressor, responsável pelo ciclo lítico. Em baixas } \\
\text { concentrações, inibe o promotor de cI. } \\
\text { - Ativador da transcrição de genes que regulam o ciclo. Apresenta } \\
\text { baixa estabilidade celular, pode ser degradado por proteases. }\end{array}$ \\
\hline $\begin{array}{c}\text { REGULAÇÃ̃O DA } \\
\text { REPLICAÇÃ O }\end{array}$ & $-\mathrm{Q}$ & - Proteína de ligação ao DNA e cofator para RNA/DNA polimerase. \\
\hline REPLICAÇÃO & $-\mathrm{OP}$ & - Gene responsável pela replicação do DNA do fago. \\
\hline LISE & - S, R & $\begin{array}{l}\text { - Genes responsáveis pela lise celular e liberação das partículas de } \\
\text { fagos no meio. }\end{array}$ \\
\hline ESTRUTURAIS & $\begin{array}{l}-\mathrm{A}, \mathrm{B}, \mathrm{C}, \mathrm{D}, \mathrm{E}, \mathrm{F} \\
-\mathrm{Z}, \mathrm{U}, \mathrm{V}, \mathrm{G}, \mathrm{T}, \mathrm{H} \\
\mathrm{M}, \mathrm{L}, \mathrm{K}, \mathrm{I}, \mathrm{J}\end{array}$ & $\begin{array}{l}\text {-Codificam estruturas da cabeça do fago. } \\
\text {-Codificam estruturas da cauda e fibras do fago. }\end{array}$ \\
\hline
\end{tabular}

* Dados obtidos de Casjens, 2003 e Sanger et al., 1982.

Várias etapas presentes no ciclo de infecção do fago lambda são comuns a todas outras classes de vírus: adsorção, separação dos ácidos nucléicos do envelope protéico, expressão e replicação dos ácidos nucléicos, montagem e liberação da partícula viral e transmissão. A adsorção do fago ocorre em duas etapas: o primeiro passo de adsorção a uma estrutura celular definida (após o contato inicial) é reversível e pode indicar uma possibilidade de "decisão" do fago em relação à infecção. Durante o segundo passo, ocorre uma ligação irreversível entre uma estrutura do fago (como as fibras da cauda) e um receptor no hospedeiro. Após a adsorção, a 
parede celular bacteriana fica penetrável (por exemplo, pela ação de enzimas do fago, presentes na cauda ou capsídeo) e o ácido nucléico viral é transportado para dentro da célula, enquanto o capsídeo permanece no lado externo. Em seguida à injeção do material genético, este se integra no genoma do hospedeiro ou permanece livre no citoplasma. Independente do tipo de vírus, há um estágio em que o genoma do fago está dissociado do genoma bacteriano (mas ainda dentro da célula hospedeira), e seu genoma pode se replicar de forma independente ao cromossomo bacteriano, porém dependente do aparato celular da célula hospedeira, de forma semelhante a um plasmídeo circular ou linear. É nessa fase que ocorrem expressão dos genes virais, replicação do genoma e morfogênese, com formação dos genomas e capsídeos (e caudas), e empacotamento do material genético (Casjens, 2003; Weinbauer, 2004).

Para que ocorra a integração, o fago temperado codifica uma enzima integrase, que medeia a recombinação entre uma seqüência curta de DNA do fago (o sítio de ligação attP) e uma sequiência curta de DNA da bactéria (o sítio de ligação attB). Cada integrase reconhece sequiências distintas. Algumas delas agem de modo autônomo, enquanto outras agem com o auxílio de outras proteínas do fago ou de fatores codificados pela bactéria hospedeira. Um fago integrado em um genoma hospedeiro é flanqueado por dois sítios híbridos, attL e attR, cada um consistindo de metade da seqüência de $a t t P$ e metade de $a t t B$. Essas seqüências att híbridas se tornam substrato para excisão por recombinação, geralmente mediada pelas integrases e uma proteína adicional do fago, chamada exciosinase, além de fatores adicionais. A reação de excisão pode ser induzida por vários fatores ambientais. O fago, ao ser liberado, reinicia o ciclo lítico. A habilidade das integrases dos fagos em recombinar de modo unidirecional duas seqüências curtas de DNA as tornam ferramentas úteis para propósito biotecnológico, geralmente para uso em engenharia genética (Groth e Calos, 2004). A figura 1.6 ilustra o mecanismo de integração do genoma de um fago lambda ao genoma bacteriano.

Fagos líticos são freqüentemente isolados de ambientes marítimos e no solo, sendo que 65\% dos fagos isolados em ambientes marítimos são líticos (Moebus, 1983; Moebus e Nattkemper, 1981). Em 80\% das linhagens da bactéria Pseudomonas aeruginosa isoladas em sedimentos de rio são identificados fagos líticos (Lammers, 1992). A mortalidade de bactérias por infecções induzidas por fagos líticos atinge $58 \%$ em ambientes marítimos e $25 \%$ em ambientes costeiros (Weinbauer, 2004). Em isolados contendo diversos gêneros de bactérias, os fagos lisogênicos são encontrados com uma freqüência de 47\% (Ackermann e DuBow, 1987), sendo que $86 \%$ dos isolados que apresentaram fagos lisogênicos podem sofrer indução do ciclo lítico quando submetidos à luz UV (Weinbauer, 2004). 


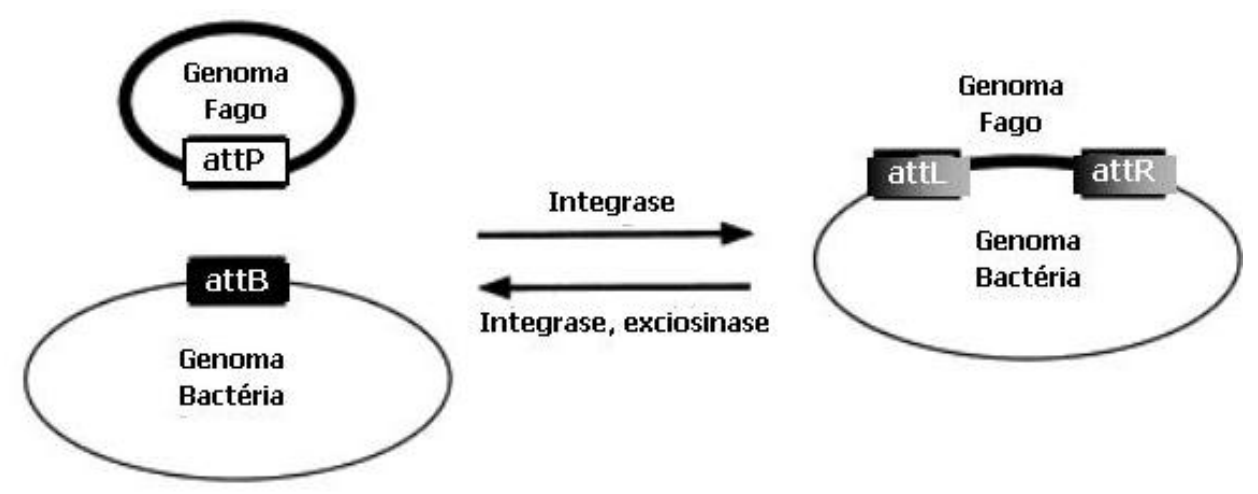

Figura 1.6. Modelo de integração e excisão do genoma do fago lambda ao cromossomo bacteriano (proposto por Campbell, 1992). As moléculas de DNA estão representadas por um círculo maior (bactéria) e menor (fago). O evento de integração origina-se a partir da associação entre regiões de reconhecimento da bactéria $(a t t B)$ e fago $(a t t P)$. Uma vez integrado ao genoma da bactéria, o genoma do fago é flanqueado por sequiências att híbridas ( $a t t L$, do inglês left, esquerda; $a t t R$, do inglês right, direita) (Adaptado de Groth e Calos, 2004).

Os fagos possuem um papel importante no processo de TGL entre bactérias. Um fago lisogênico, quando induzido ao ciclo lítico, no momento da excisão, pode carregar genes adjacentes ao sítio de integração devido a uma excisão imperfeita. Neste caso, uma versão modificada do fago original será formada, caracterizando um evento chamado de transdução

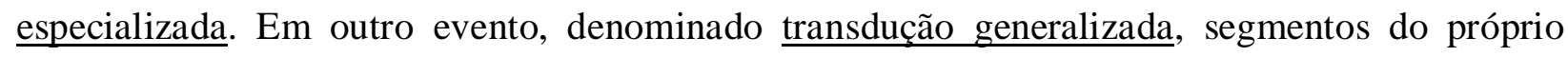
cromossomo bacteriano distantes do sítio de integração podem ser capturados no momento da montagem do capsídeo e empacotados no bacteriófago. Em ambos os casos, existe a possibilidade de que a informação contida no cromossomo bacteriano original seja incorporada por outra bactéria susceptível ao mesmo fago em um evento de infecção futura (Figura 1.7). Desta forma, o fago pode carregar, além dos genes essenciais (genes do ciclo lítico e ciclo lisogênico), um conjunto de genes não essenciais, não relacionados ao processo de infecção viral, e que podem ser transferidos lateralmente a outros organismos em infecções posteriores (Casjens, 2003). Portanto, o processo de transdução contribui para geração de variedade genética nas populações de bactérias que, além de ser um pré-requisito para mudanças evolutivas, também influencia na dinâmica de populações do hospedeiro (Weinbauer, 2004). 


\subsection{RECOMBINAÇÃO SÍTIO-ESPECÍFICA E A FAMÍLIA DAS RECOMBINASES}

Recombinação sítio-específica (RSE, ou SSR, do inglês site-specific recombination) é o nome usado para descrever uma série de processos de recombinação, que envolvem trocas recíprocas entre sítios específicos na seqüência de DNA. A RSE envolve: (a) dois parceiros de DNA, (b) uma proteína recombinase específica responsável pelo reconhecimento dos sítios e pela quebra e re-ligação do DNA, e (c) um mecanismo que envolve a quebra e união do DNA com conservação da energia da ligação fosfodiéster. Os processos-modelo de RSE são (1) a integração do bacteriófago lambda no cromossomo de E. coli, (2) a resolução de cointegrados derivados da transposição de transposons família Tn3, e (3) as inversões de DNA responsáveis pela variação de fase flagelar em Salmonella (Grindley et al., 2006).

A
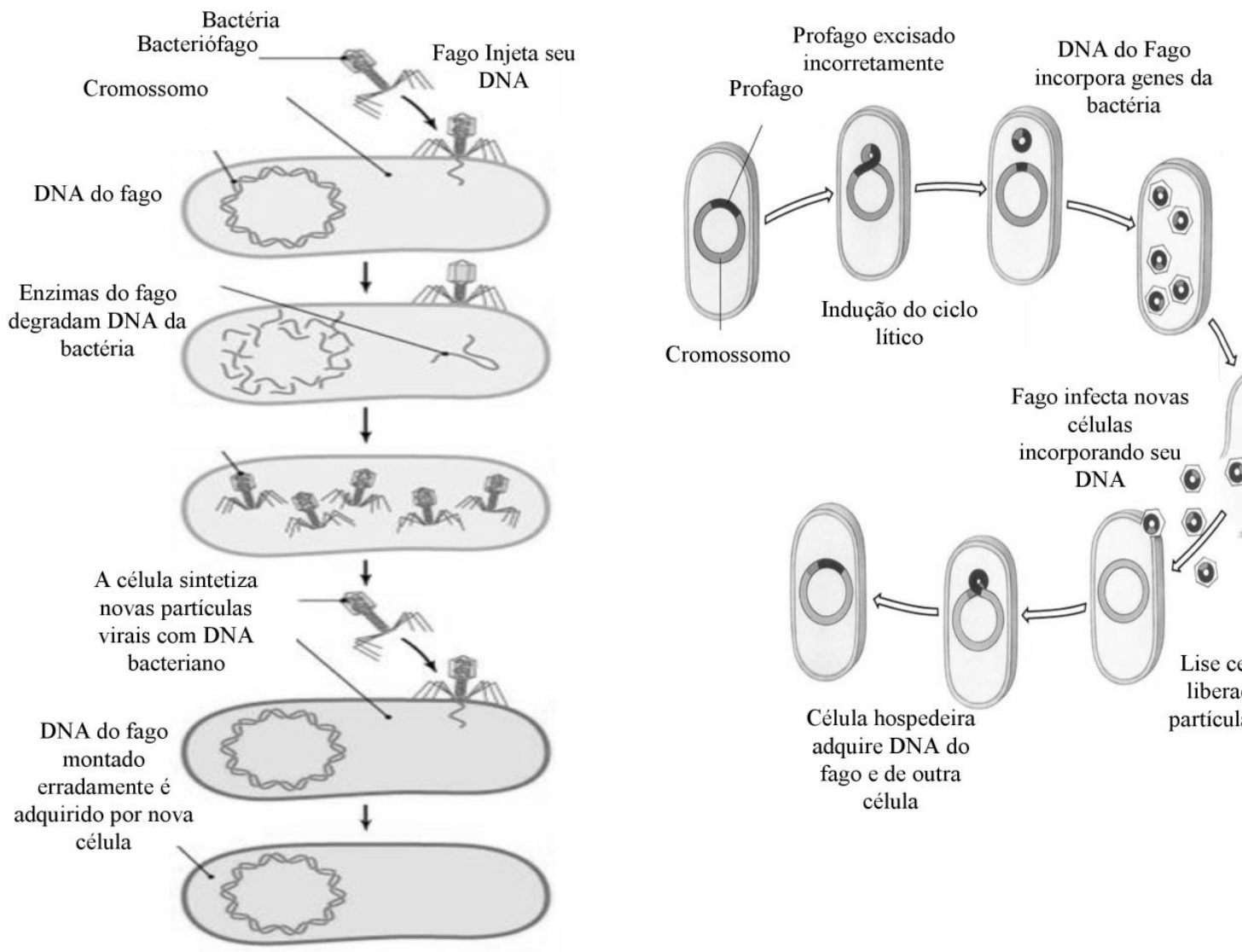

Cromossomo

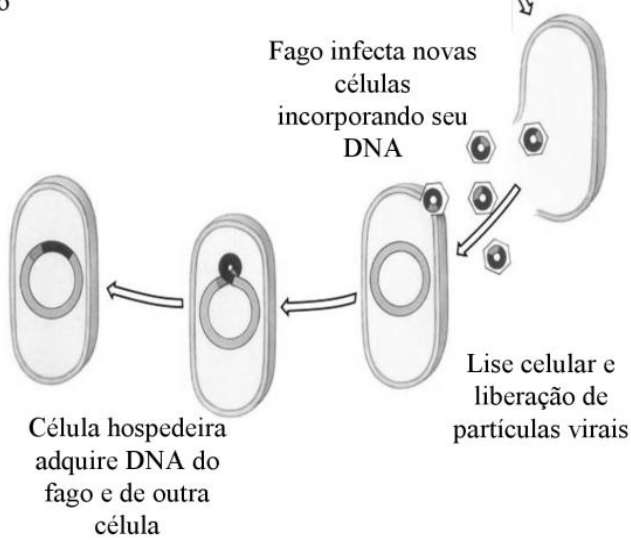

Figura 1.7. Modalidades de eventos de transdução. Figura A, transdução generalizada; Figura B, transdução especializada (adaptado de http://faculty.ircc.edu). 
Dependendo do arranjo inicial dos sítios de recombinação parentais, a recombinação pode resultar em integração, excisão ou inversão (Figura 1.8). A integração resulta da recombinação entre sítios em moléculas de DNA distintas (sendo que ao menos uma delas deve estar na forma circular) e ocorre com uma orientação única definida. Para sítios localizados no mesmo cromossomo, o resultado da recombinação depende da orientação relativa dos sítios. A excisão resulta da recombinação entre sítios em uma orientação “head-to-tail”, enquanto a inversão resulta de trocas entre sítios invertidos (head-to-head). Os três processos são usados para uma grande variedade de objetivos nos sistemas biológicos, mas de modo geral a RSE é usada por um organismo ou um elemento genético primariamente para unir ou separar fisicamente segmentos de DNA. No entanto, esse processo também é usado para ativação ou modulação da expressão gênica ou para gerar diversidade genética através da aquisição de genes ou segmentos gênicos (Grindley et al., 2006).

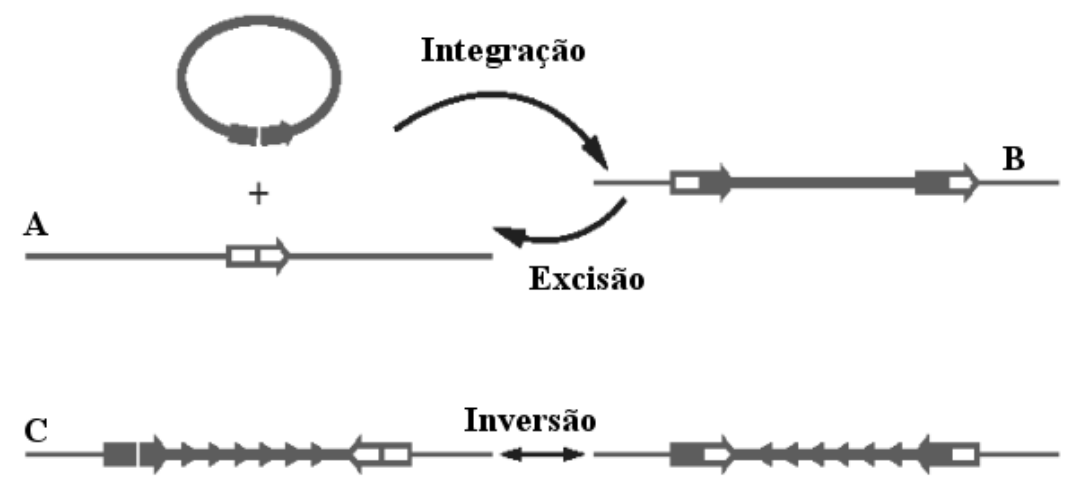

Figura 1.8. Representação dos mecanismos de recombinação sítio-específica. A, integração. B, excisão. C, inversão (Adaptado de Grindley et al., 2006).

Os componentes mínimos para RSE são uma recombinase e um par de sítios de recombinação. Os sítios mais simples são segmentos curtos de DNA dupla-fita, com 20 a 30 pb de comprimento, que contêm um par invertido de seqüências de reconhecimento, e se ligam a um dímero (ou dois monômeros) da recombinase. Tais sítios contêm em seu centro o ponto de quebra e ligação do DNA, e esses são denominados sítios de "crossover". O processo de RSE pode ser dividido, conceitualmente, em uma série de passos simples. A recombinase se liga aos dois sítios de recombinação. As duas recombinases ligadas aos sítios no DNA se emparelham, formando um complexo sináptico com sítios justapostos. A recombinase então catalisa a clivagem, troca de fitas e re-ligação do DNA ao complexo. Por fim, o complexo sináptico é quebrado, liberando os produtos recombinantes (Grindley et al., 2006). 
Apesar das distintas funções biológicas da RSE e do grande número de sistemas identificados, comparações das seqüências de aminoácidos das recombinases indicam que elas formam duas grandes famílias: as tirosinas recombinases e as serinas recombinases (Tabela 1.2) (Grindley et al., 2006).

\subsubsection{Tirosinas Recombinases}

As tirosinas recombinases são as mais difundidas entre os procariotos, mas também são encontradas em árqueas e eucariotos, compartilhando um domínio catalítico com motivos facilmente reconhecidos. Estudos da estrutura protéica indicam que o dobramento do domínio catalítico é conservado mesmo quando a identidade de seqüência fora da região do sítio ativo é insignificante (Grindley et al., 2006).

Tabela 1.2. Exemplo das duas famílias de recombinases sítio-específicas (Extraído e adaptado de Grindley et al., 2006).

\begin{tabular}{cll}
\hline \multicolumn{2}{c}{ Recombinases } & \\
\hline Família das tirosinas recombinases & \multicolumn{1}{c}{ Função Biológica } \\
- & Integrases do fago Lambda $(*)$ & Integração e excisão no genoma de fagos (Ex. fago lambda de E. coli) \\
- & Int Tn916/Tn1545 & Integração e excisão: transposição de transposons circulares \\
- & IntI & Integração e excisão de cassetes gênicos de integrons \\
- & Cre & Excisão (Ex. Fago P1) \\
- & XerC / XerD & Excisão \\
- & TnpI de Tn4430 & Excisão \\
- & FimB, FimE & Inversão \\
- & Rci de R64 & Inversão de fragmentos do plasmídeo R64 \\
- & XisA, XisC & Excisão \\
- & Flp & Inversão \\
\hline Família das serinas recombinases & \\
- & TnpR (transposons) & Excisão: resolução de cointegrados resultantes da transposição \\
- & Sin ( S. aureus) & Excisão \\
- & ParA de RP4 & Excisão \\
- & Hin & Inversão \\
- & Gin, Cin & Inversão \\
- & OrfA do IS607 / IS1535 & Integração e Excisão \\
- & Integrase do Fago phi $(*)$ & Integração e Excisão no genoma de fagos (Ex. Fago phi de Streptomyces) \\
- & TnpX do Tn4451 & Integração e Excisão \\
- & SpoIVCA (CisA) & Excisão \\
- & XisF & Excisão \\
\hline
\end{tabular}

(*) Destaque para as integrases de fagos

Cada tirosina recombinase tem um sítio de DNA específico, e compreende no mínimo um par de sítios invertidos de ligação à enzima, separados por um espaçador de 68 pb. A 
recombinação tem início quando uma fita de cada duplex é clivada por uma tirosina nucleofílica, criando ligações fosfotirosina covalentes DNA-proteína nas extremidades 3' do DNA e hidroxilas livres nas extremidades 5'. A energia da ligação fosfodiéster da cadeia de DNA é transferida à fosfotirosina. Ainda que a recombinação exija a sinapse dos dois sítios, a clivagem de uma única fita, ao menos em alguns casos, requer apenas um dímero. O próximo passo envolve uma troca onde a extremidade 5' livre ataca a fosfotirosina 3' do substrato de DNA oposto, formando uma junção Holliday. O complexo pode então isomerizar, e os monômeros inativos se tornarão ativos, e vice-versa. Isso permite que o processo se repita, ou seja, a segunda fita, não-alterada, é atacada e a nova extremidade 5' ataca as ligações fosfotirosina 3', liberando a recombinase, resolvendo a junção Holliday e completando a reação (Figura 1.9).

\subsubsection{Serinas Recombinases}

As serinas recombinases são um grupo mais heterogêneo de proteínas, podendo variar de 180 a 800 aminoácidos em seu tamanho, e mostram uma grande variedade de organização do domínio protéico. A maior parte das informações sobre estrutura do domínio e função dessas proteínas vem da recombinase protótipo $\gamma \delta$-resolvase, que foi caracterizada extensivamente bioquímica e estruturalmente. Essa proteína possui 183 resíduos, com um domínio N-terminal de 100 aminoácidos, ligados por uma longa (36 resíduos) $\alpha$-hélice (ou E-hélice) a um domínio HTH (helix-turn-helix), típico de ligação ao DNA na porção C-terminal. A serina nucleofílica, típica do grupo, se localiza no resíduo 10.

Os processos catalíticos de quebra de DNA e troca de fitas normalmente ocorrem dentro do complexo sináptico com dois sítios de crossover e quatro subunidades da recombinase. Nos complexos sinápticos formados pelas serinas recombinases, os sítios de crossover se localizam na parte de fora, separados pelos domínios catalíticos, em contraste com o que ocorre nos complexos formados pelas tirosinas recombinases.

Uma vez que o complexo sináptico é formado, as quatro subunidades da recombinase são ativadas pelo ataque dos sítios de crossover, formando duas quebras dupla-fita (Figura 1.10). Esta reação liga covalentemente as quatro subunidades através de uma ligação fosfoserina às quatro extremidades $5^{\prime}$ das fitas quebradas, deixando hidroxilas livres nas extremidades 3'. O espaçamento dos fosfatos é tal que a clivagem deixa uma extensão simples-fita de duas bases em cada extremidade $3 '$. 


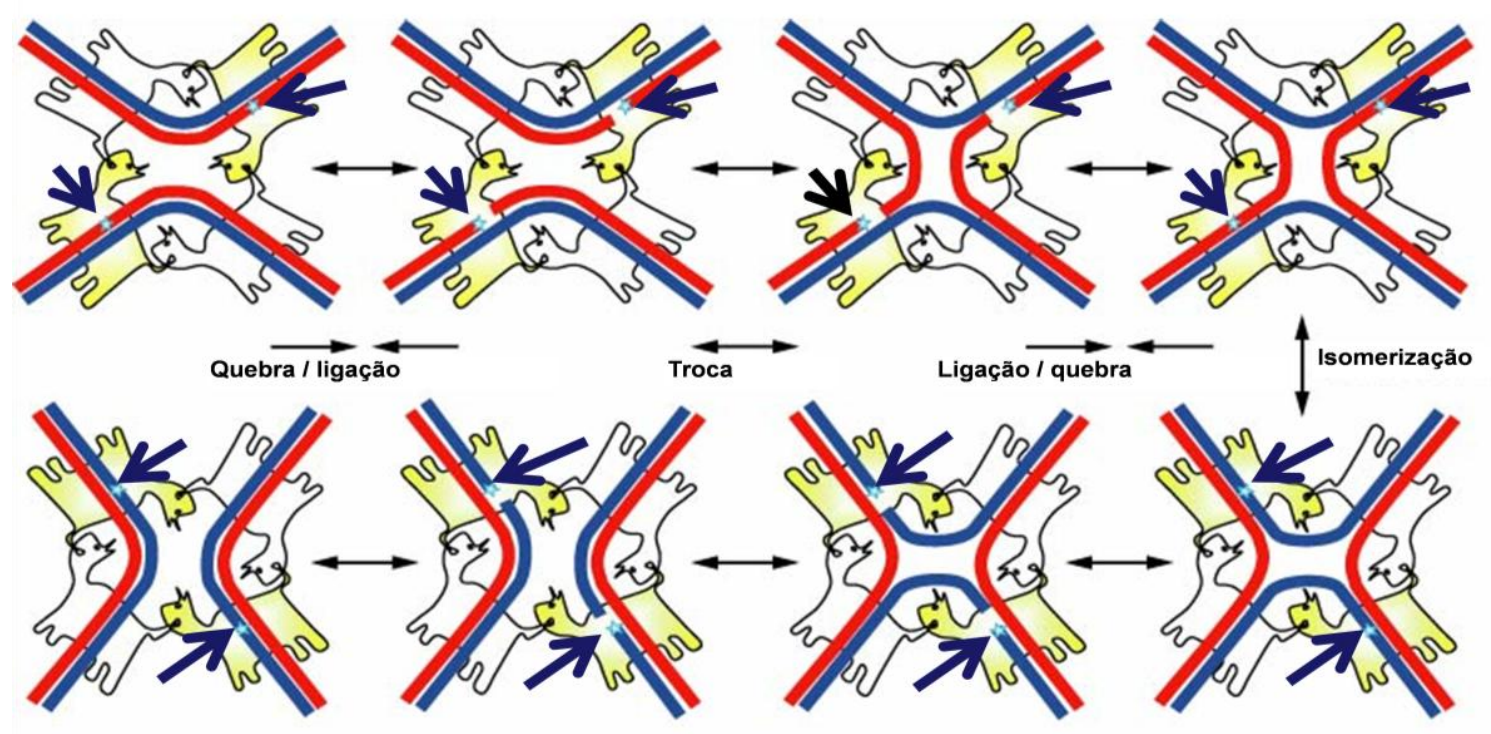

Figura 1.9. Representação do mecanismo de recombinação das tirosinas recombinases. O complexo sináptico é formado pela ligação de dois duplex de DNA a cinco promotores de recombinases montados em formato "heat-to-tail". As setas em azul escuro indicam os centros catalíticos dos promotores ativos (representados na cor amarela). Uma fita de cada duplex é quebrada, recombinada e ligada através de uma junção Holliday. A isomerização desta junção alterna a atividade catalítica entre os dois pares de promotores (adaptado de Grindley et al., 2006).
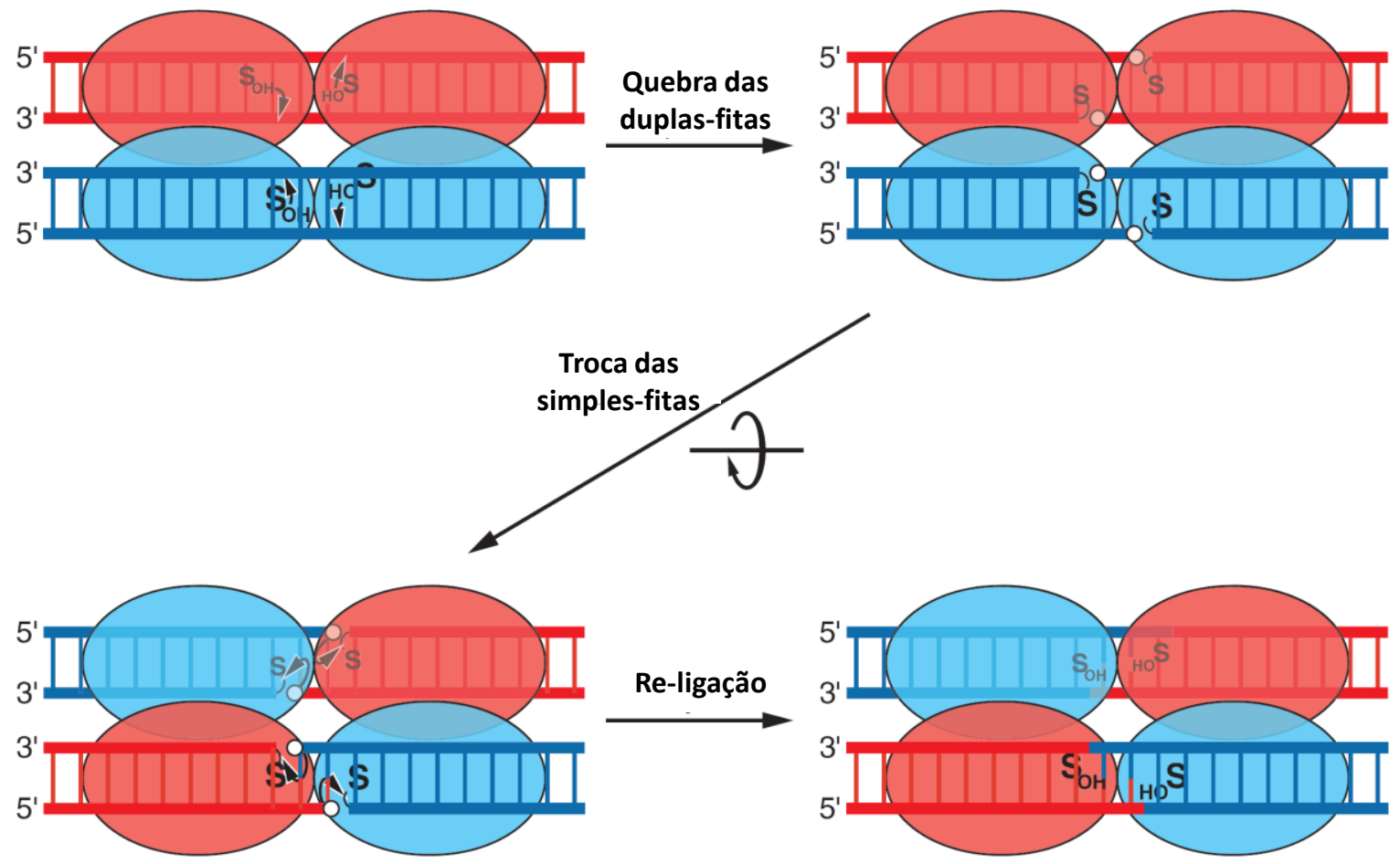

Figura 1.10. Representação do mecanismo de recombinação das serinas recombinases. A figura ilustra o complexo sináptico formado pelo par "recombinase- sítio de crossover". Apenas o domínio catalítico da recombinase é mostrado; eles são os responsáveis pelo pareamento e separação de duas moléculas de DNA. O resíduo nucleofílico de serina é representado por "Sон" quando livre ou "S" quando ligado à extremidade 5' do DNA. O grupo OH livre na porção 3' no ponto de quebra do DNA é representando como pequenos círculos brancos. Durante a recombinação das fitas de DNA, os domínios catalíticos e as moléculas de DNA estão unidos por uma ligação covalente (adaptado de Grindley et al., 2006). 


\subsubsection{Integrases de fagos}

$\mathrm{Na}$ infecção por fagos, a atividade enzimática responsável pelo corte do DNA bacteriano e pela inserção do DNA viral no cromossomo é realizada por proteínas com domínio integrase. As integrases de fagos são uma subfamília dentro da família das recombinases sítioespecíficas, sendo também divididas em tirosinas e serinas recombinases, segundo o domínio catalítico e a similaridade da sequiência de aminoácidos (Tabela 1.3). A figura 1.11 ilustra o esquema das integrases, com destaque para os domínios catalíticos entre as serinas e tirosinas recombinases.

As tirosinas recombinases de fagos, durante o processo de integração ou excisão, são auxiliadas por outros cofatores ou proteínas codificados pelo fago ou fornecido pela bactéria hospedeira. A integrase do fago lambda requer a expressão do fator IHF, assim como os fagos HK022 e HP1. O fator IHF é formado por duas subunidades codificadas pelos genes himA e hip atuando com a função de ligar os sítios attP na molécula de DNA. Já para as serinas recombinases não existem evidências de requerimento de cofator (Groth e Calos, 2004).

O membro das tirosinas recombinases de fagos mais estudado é a integrase presente no fago lambda, composta por 356 aminoácidos (Figura 1.11). O domínio N-terminal inclui 64 resíduos, e é responsável pela ligação dos sítios arm da attP. O domínio C-terminal contém o sítio catalítico, e possui duas regiões com atividades distintas. Os resíduos 65-169 são responsáveis pela ligação aos sítios centrais (core-sites), e os resíduos 170-356 constituem o domínio catalítico. A tirosina catalítica e os resíduos "RKHRH" estão nessa região. As duas regiões, C- e N-terminal, contribuem para as interações proteína-proteína entre os monômeros das integrases. O sítio de inserção, na bactéria, é flanqueado por repetições inversas (IR) imperfeitas denominadas principais sítios de ligação (do inglês core-bindind site, cbs) possuindo tamanho entre 9 e 13 pb. O sítio de inserção no genoma do fago é mais complexo, formado por vários sítios chamados de braços de ligação (do inglês arm-type site, AS), que apresentam sítios de ligação para outros fatores envolvidos na integração e excisão (Groth e Calos, 2004).

A estrutura cristalográfica do domínio catalítico da tirosina recombinase integrase do fago lambda já foi elucidada na resolução de 1,9 ̊ (Figura 1.12). A estrutura desta integrase mostrou-se conservada de árqueas a fungos, sendo um modelo para estudos de interações entre proteínas integrases com a molécula de DNA. A quebra e re-ligação da ligação fosfodiéster ocorrem através de uma ligação covalente de fosfotirosina intermediada pelo resíduo tirosina na posição 342 (Tyr342) da proteína com a porção 3' fosfato da molécula de DNA (Kwon et al., 1997). 


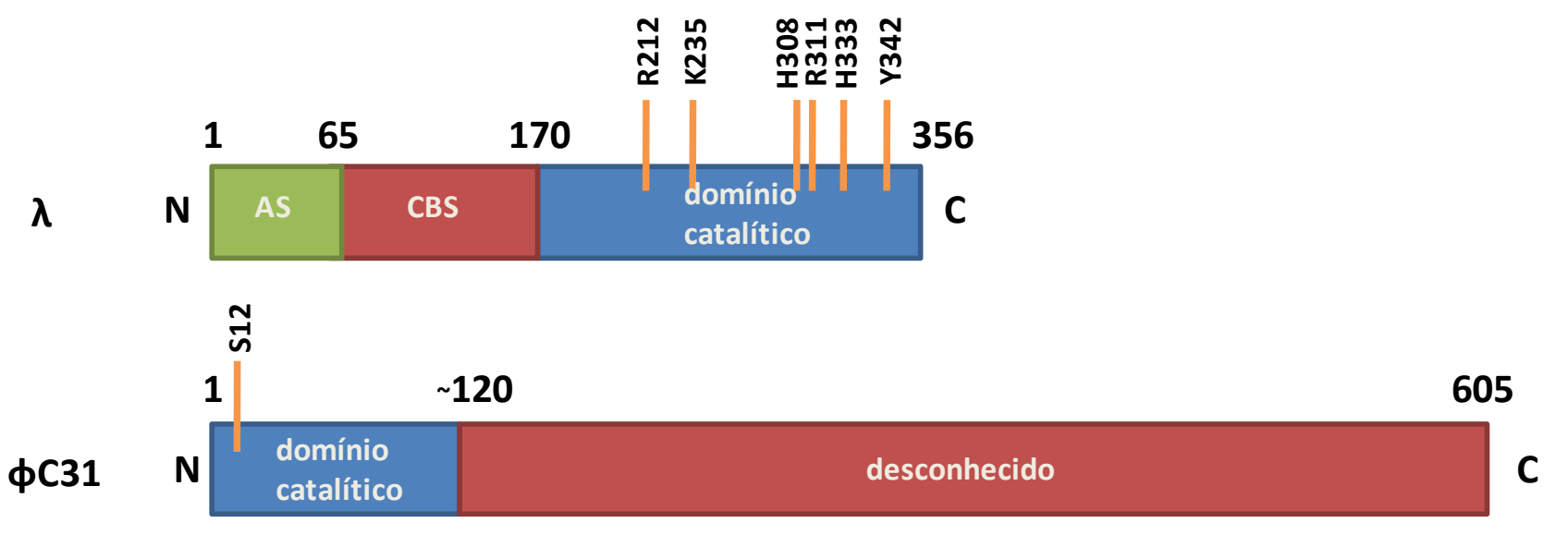

Figura 1.11. Representação esquemática dos domínios catalíticos das integrases de fagos, através dos modelos mais estudados na literatura (lambda para tirosina recombinase e ФС31 para serina recombinase). Detalhe para o posicionamento dos resíduos de aminoácidos responsáveis pela atividade catalítica. Abreviações: AS, braços de ligação; CBS, principais sítios de ligação ao cromossomo bacteriano (modificado de Groth e Calos, 2004).

A
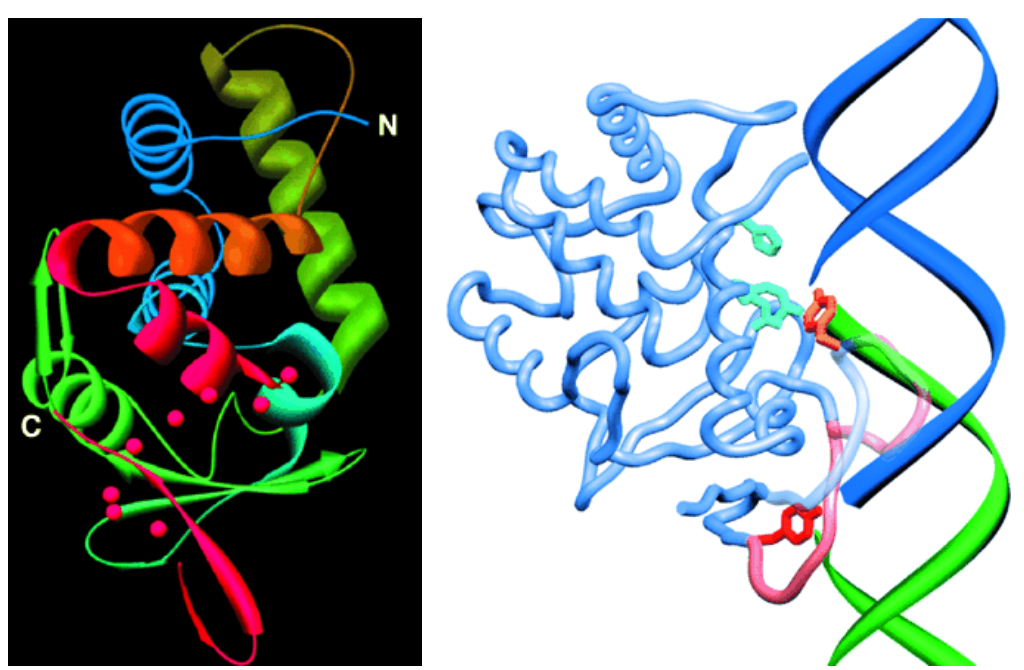

Figura 1.12. Estrutura $3 \mathrm{D}$ e modelo teórico de interação com DNA da integrase do fago lambda. A, Estrutura tridimensional do domínio catalítico da integrase do fago lambda; em destaque as porções $\mathrm{N}$ - e Cterminal. B, Modelo teórico da interação entre o domínio catalítico da integrase lambda com a molécula de DNA; a integrase quebra a ligação fosfodiéster da molécula de DNA pela formação de ligação covalente fosfotirosina entre a porção 3' fosfato e entre a hidroxila livre a porção 5' (extraído de Kwon et al., 1997).

Na família das serinas recombinases de fagos, os membros mais estudados são uma resolvase e uma invertase, que apresentam menos de 200 resíduos e dois domínios distintos. O 
domínio N-terminal, composto por aproximadamente 120 aminoácidos, é responsável pelas interações proteína-proteína e catálise, enquanto o domínio C-terminal possui um motivo HTH (helix-turn-helix) com função de ligação ao DNA. O domínio N-terminal é similar ao encontrado em outras proteínas da família das resolvases/invertases, mas os resíduos adicionais encontrados na região C-terminal contém baixa similaridade com as seqüências das outras resolvases. Com base na similaridade de seqüência e estudos com mutantes, o sítio catalítico dessas integrases foi identificado na porção $\mathrm{N}$-terminal, sendo sua assinatura a presença do resíduo de aminoácido serina entre a posição 10 e 20 e também por diversos resíduos cisteína ao longo da porção amino-terminal. O sítio de inserção na bactéria e no genoma do fago apresenta em média 3 pb, flanqueada geralmente por dois IR imperfeitos (Groth e Calos, 2004).

A especificidade das integrases de fagos a uma determinada região no cromossomo bacteriano não é completamente elucidada, mas sabe-se da associação das integrases de fagos, assim como das integrases de IG, a regiões no genoma de bactérias onde RNA transportadores (tRNAs) estão presentes, utilizando-os como sítios de inserção através do pareamento de segmentos entre attP e $a t t B$ (Williams, 2002). Em algumas ocasiões, o evento de integração provoca interrupção do tRNA; em outras, o profago carrega parte de tRNA necessária para a reconstituição do mesmo no cromossomo bacteriano, sendo que alguns fagos podem carregar cópias inteiras de tRNAs (Brussow et al., 2004; Campbell 1992; Canchaya et al., 2003a).

Tabela 1.3. Principais características entre as integrases de fagos (tirosinas e serinas recombinases) (adaptado de Groth e Calos, 2004).

\begin{tabular}{|c|c|c|}
\hline & Tirosinas Integrases & Serinas integrases \\
\hline $\begin{array}{l}\text { Resíduo } \\
\text { Catalítico }\end{array}$ & Tirosina & Serina \\
\hline Mecanismo & Formação e resolução da junção holliday & $\begin{array}{l}\text { 2-pb cortados e ligados após rotação em } \\
180^{\circ}\end{array}$ \\
\hline attB & $\begin{array}{c}\text { Curtas, com sobreposição flanqueada por } \\
\text { pequenos IR imperfeitos }\end{array}$ & $\begin{array}{l}\text { Curtas, com sobreposição geralmente } \\
\text { flanqueada por pequenos IR imperfeitos }\end{array}$ \\
\hline attP & $\begin{array}{l}\text { Extensa, múltiplos sítios de integração para } \\
\text { integrases, fatores do hospedeiro e cofatores }\end{array}$ & $\begin{array}{l}\text { Curtas, com sobreposição geralmente } \\
\text { flanqueada por pequenos IR imperfeitos }\end{array}$ \\
\hline Sobreposição & $6-8 \mathrm{pb}$ & $3-12 \mathrm{pb}$ \\
\hline Cofator & $\operatorname{Sim}($ ex. HimA-IHF) & Não \\
\hline
\end{tabular}




\subsection{A BACTÉRIA XYLELLA FASTIDIOSA (Xf)}

Numerosas espécies de bactérias podem ser isoladas de plantas, porém apenas um pequeno número de espécies habita exclusivamente o xilema de plantas, sendo o termo bactéria limitada ao xilema (do inglês xylem-limited bacteria) utilizado para descrever este grupo de bactérias. Algumas dentre estas são patogênicas e apresentam difícil isolamento pelos procedimentos bacteriológicos padrões (Purcell e Hopkins, 1996). Neste grupo, encontram-se as espécies Xylella fastidiosa (Wells et al., 1987), Pseudomonas syzygii (Roberts et al., 1990) e Leifsonia xyli subsp. xyli (Davis et al., 1984). O gênero Xylella está classificado dentro do grupo das proteobactérias, na classe das gama-proteobactérias, dentro da ordem Xanthomonadales (Wheeler et al., 2007) (Figura 1.13).

Xylella fastidiosa (Xf) é uma bactéria gram-negativa, que não apresenta flagelo e, quando submetida a condições de estresse fisiológico, não é capaz de formar esporos. Apresenta forma de bastonete reto e curvo, com 3-5 $\mu \mathrm{m}$ de comprimento por 0,3-0,5 $\mu \mathrm{m}$ de diâmetro, estritamente aeróbio e que somente cresce em meio de cultura especial, pois exige vários aminoácidos, micronutrientes e macronutrientes para garantir seu desenvolvimento pleno (Wells et al., 1987). A figura 1.14 ilustra vasos xilemáticos repletos de colônias da bactéria.

Em 1978, Davis e colaboradores, usando um meio de cultura bacteriano, conseguiram pela primeira vez o isolamento da linhagem associada ao mal de Pierce (Xf-PD). Em 1987, foi identificada oficialmente no Brasil em pomares do Triângulo Mineiro e do Norte e Noroeste do Estado de São Paulo (http://www.fundecitrus.com.br). Até 1993, acreditava-se que era restrita ao continente americano; entretanto, relatos de sua presença na Ásia (Leu e Su, 1993) e na Europa (Berisha et al., 1998) demonstram que essa bactéria apresenta distribuição global.

O gênero apresenta dois grupos de hospedeiros, um grupo no reino animal pertencente à família das cigarras (Hemiptera), e outro grupo no reino vegetal, sendo esse último relativamente amplo em termos taxonômicos (Hopkins, 1989; Purcell e Hopkins, 1996).

A transmissão é realizada no momento em que o inseto se alimenta, através do mecanismo de sucção presente em sua peça bucal, que é capaz de penetrar nos vasos lenhosos dos vegetais, possibilitando acesso ao xilema, e neste momento passa a alojar a bactéria na porção anterior de seu tubo digestivo. Insetos adultos podem transmiti-la logo após a sua aquisição, não necessitando de um estado latente. Uma vez infectivos, esses insetos adultos são capazes de transmitir a bactéria eficientemente pelo resto de sua vida, até que ocorra a muda, quando então só serão capazes de transmitir Xf se forem novamente infectados. 


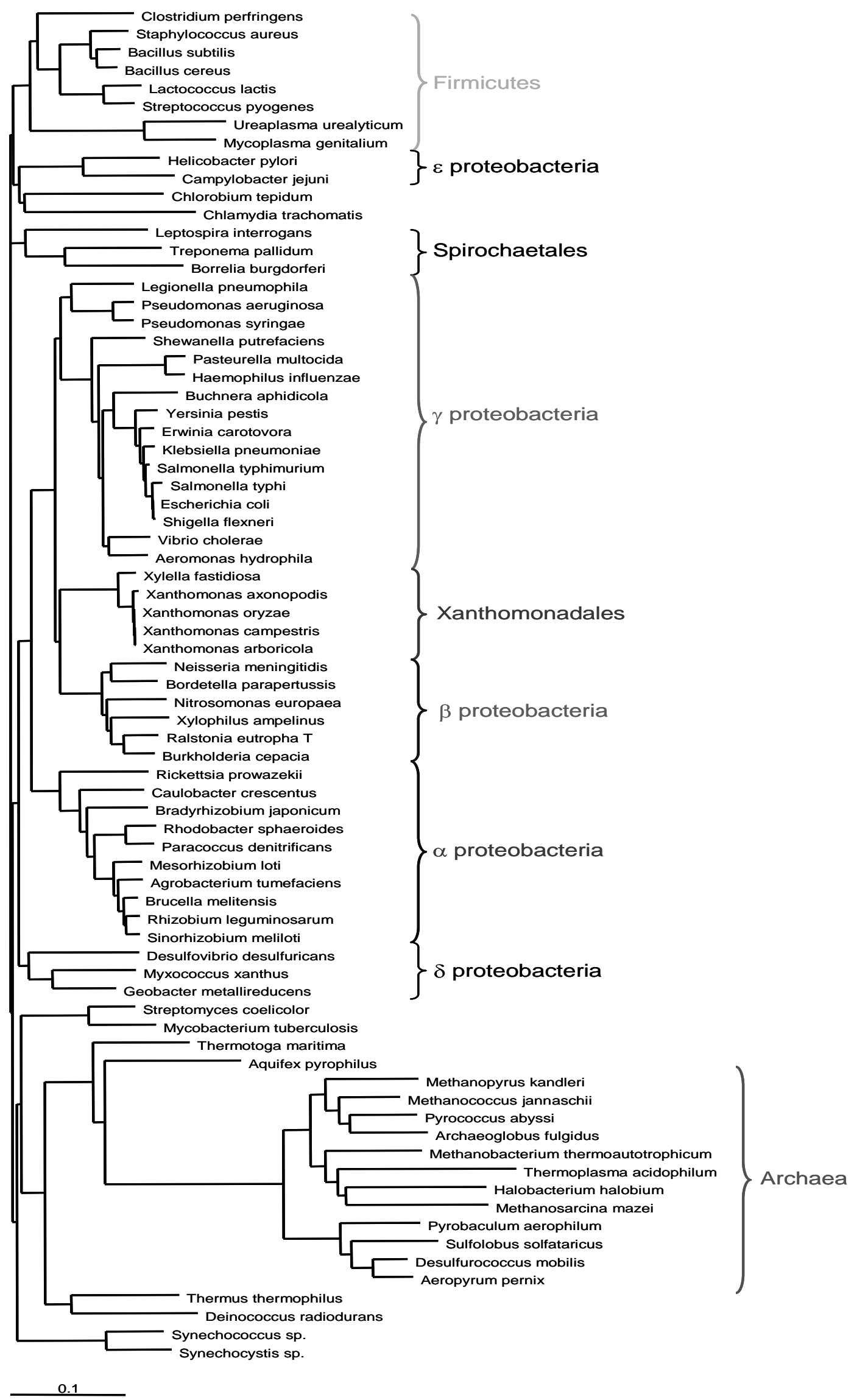

Figura 1.13. Árvore de rRNA 16S, mostrando a posição do gênero Xylella dentro do grupo de Bactérias. Árvore obtida pelo método de neighbor-joining através do Ribosomal Database Project (Cole et al., 2003) (http://rdp.cme.msu.edu) (extraído e adaptado de Lima et al., 2005). 


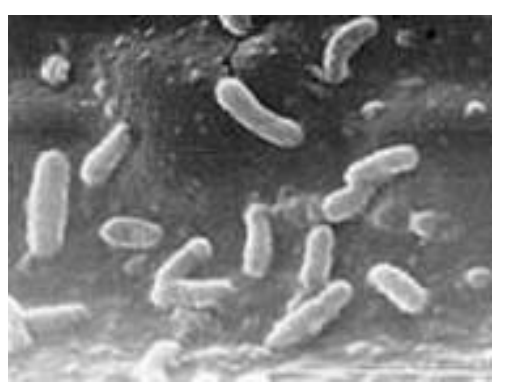

A

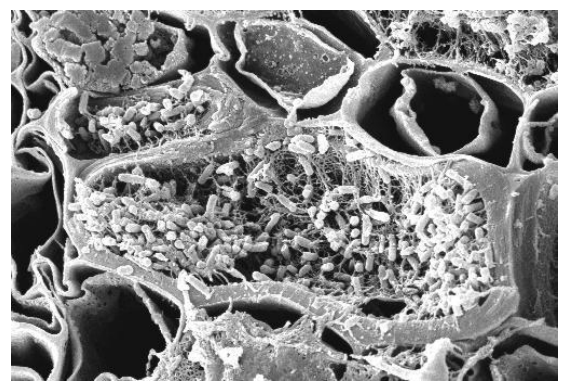

Figura 1.14. Microscopia eletrônica de um vaso de xilema. Figura A, Detalhe de Xf aderida ao xilema (ca x 8,000) (http://www.fundecitrus.com.br). Figura $\mathbf{B}$, Colônias de Xf aderida às paredes do xilema (ca x 4,000) (http://aeg.lbi.ic.unicamp.br/xf)

Dentre o grupo dos hospedeiros de Xf do reino vegetal incluem-se ao menos 28 famílias de plantas mono e dicotiledôneas (Purcell e Hopkins, 1996), sendo mais de 22 espécies de gramíneas relatadas como hospedeiras (Hopkins, 1989). As principais etiologias descritas são encontradas em plantas frutíferas e ornamentais. Entre as doenças de maior importância econômica, destacam-se a Clorose Variegada dos Citros (CVC) (Rosseti et al., 1990) e o mal de Pierce (PD) em videiras (Davis et al., 1978). Há também outras linhagens que infectam amendoeira e espirradeira, ameixas, carvalho, café e diversas outras espécies vegetais (Hartung et al., 1994; Purcell e Hopkins, 1996). Plantas infectadas podem apresentar sintomas variados, sendo que algumas podem até se mostrar assintomáticas, apesar de apresentarem todos os vasos infectados, enquanto outras plantas apresentam quadro sintomatológico grave (Purcell e Hopkins, 1996).

No caso das laranjeiras, os sintomas da CVC incluem clorose internerval, redução do tamanho da folha, frutos duros e com menor tamanho (Rosseti et al., 1990); em videiras e amendoeira, os sintomas incluem necrose marginal das folhas, redução do crescimento, maturação irregular e secamento dos frutos e folhas (Davis et al., 1978); em espirradeira, os sintomas incluem necrose marginal com halos cloróticos que evoluem para o interior das folhas e diminuição no tamanho das folhas. Em todos os casos, estes sintomas podem evoluir para toda a planta levando as mais susceptíveis a morte. A figura 1.15 ilustra alguns dos sintomas identificados em plantas infectadas.

Diversos autores divergem em relação aos prováveis mecanismos de patogênese. Existem diferentes hipóteses, incluindo disfunções do sistema condutor de água, produção de fitotoxinas e alteração na concentração de reguladores de crescimento (Hopkins et al., 1995). O quadro sintomatológico de plantas infectadas oferece evidências de que a primeira hipótese seja mais provável. Embora outros mecanismos possam estar envolvidos, o principal mecanismo de patogênese é relacionado à oclusão dos vasos do xilema devido a agregados de bactérias; reações de resistência como a deposição de goma, pectina; formação de tilose pelo hospedeiro (Fry e 
Millholand, 1990; Mollenhauer e Hopkins, 1976); e formação de cristais de cálcio nos vasos (Tyson et al., 1985) que resultam em estresse hídrico e possivelmente causam cavitação com embolia (Schultz e Mattews, 1988). A agregação da bactéria parece estar ligada à produção de um biofilme constituído de polissacarídeos, responsável pela adesão de outras bactérias. Este agregado de bactérias funciona como uma rede no xilema, que apresenta a função de reter íons e nutrientes para a colônia bacteriana, resultando em otimização da atividade enzimática da colônia, com conseqüente multiplicação bacteriana. Isto resulta em deficiências nutricionais para a planta, mesmo apresentando poucos vasos obstruídos (Leite et al., 2004).

A

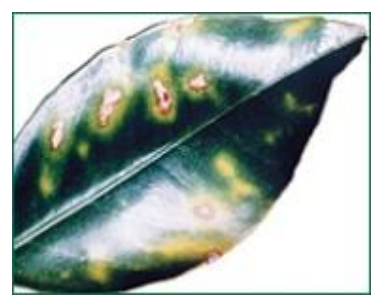

B

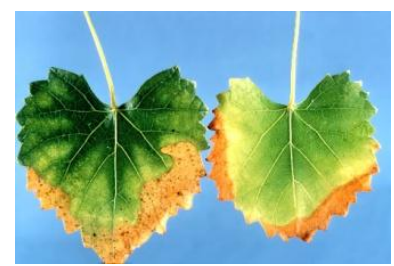

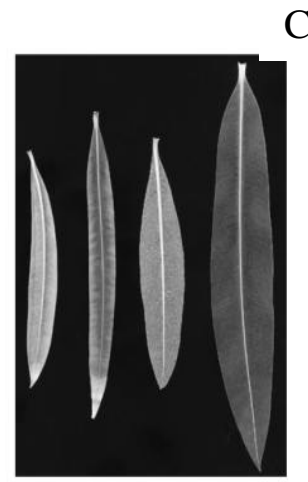

Figura 1.15. Fotografias ilustrativas dos sintomas identificados em plantas infectadas por Xf. A, detalhe de clorose internerval em CVC (http://www.fundecitrus.com.br). B, detalhe de necrose foliar em PD (http://nature.berkeley.edu/xylella). C, detalhe da diminuição do tamanho de folhas em plantas de Espirradeira infectadas, seguindo escala da esquerda para direita, sendo a última folha da direita não infectada, utilizada como controle negativo (Purcell e Hopkins, 1996).

\subsubsection{O Genoma de Xylella fastidiosa (Xf)}

O estudo de um genoma é uma tarefa complexa, envolvendo diversas etapas com a finalidade de determinar a seqüência de bases do organismo em estudo, com posterior identificação e caracterização de seu potencial codificante. Para chegar a este fim, os projetos genomas costumam seguir duas metodologias. A primeira visa determinar a seqüência completa ou parcial de bases do genoma em estudo, e a segunda pretende identificar pequenas seqüências expressas, sendo esta etapa geralmente empregada em estudo de genomas de organismos eucariontes (Binneweis et al., 2006)

Xf-CVC (linhagem 9a5c, origem São Paulo, Brasil) foi o primeiro fitopatógeno a ter seu genoma completamente seqüenciado (Simpson et al., 2000). Hoje, há mais de 21 genomas completos de bactérias fitopatogênicas seqüenciadas (http://www.ncbi.nlm.nih.gov). Dentre estes genomas, destaca-se o seqüenciamento parcial das linhagens Xf-AL (linhagem Dixon) e Xf-OL 
(linhagem Ann1) realizados em 2002 (Bhattacharyya et al., 2002), e o seqüenciamento completo de Xf-PD (linhagem Temecula1, origem Califórnia, EUA) em 2003 (Van Sluys et al., 2003) (Tabela 1.4). As quatro linhagens de Xf sequienciadas apresentam plasmídeos em forma epissomal. Xf-CVC carrega um plasmídeo maior e circular (pXF51) e outro menor (pXF1.3). Xf-PD apresenta apenas o plasmídeo pequeno (pXFPD1.3). Xf-AL e Xf-OL apresentam plasmídeo circular (pXF30 e pXF31, respectivamente) seqüenciados completamente. Análises comparativas a partir da seqüência de nucleotídeos apontam que pXF30 não apresenta similaridade de seqüência em relação à pXF51 e pXF31, indicando independência em sua origem (Bhattacharyya et al., 2002; Monteiro-Vitorello et al., 2005).

Tabela 1.4. Principais características genômicas identificadas nos genomas de Xf. A, Xf-CVC e Xf-PD (Van Sluys et al., 2003). B, Plasmídeos de linhagens de Xf seqüenciadas (Monteiro-Vitorello et al., 2005). C, XfOL e Xf-AL (Bhattacharyya et al., 2002)

\begin{tabular}{l|c|c}
\hline Principais Características & Xf-PD & Xf-CVC \\
\hline Tamanho (em pares de bases; pb) & 2.519 .802 & 2.679 .305 \\
\hline Conteúdo de Guanina/Citosina (GC\%) & $51,8 \%$ & $52,7 \%$ \\
\hline Quantidade de Quadros Abertos de Leitura (ORFs) & 2.066 & 2.249 \\
\hline Tamanho Médio de cada ORF (em pb) & 979 & 964 \\
\hline ORFs com provável função identificada & $65,9 \%$ & $57,2 \%$ \\
\hline tRNA & 49 & 49 \\
\hline
\end{tabular}

\begin{tabular}{c|c|c|c|c}
\hline Linhagem & Plasmídeo & Tamanho (pb) & GC\% & Número de ORFs Preditas \\
\hline \multirow{2}{*}{ Xf-CVC } & pXF51 & 51.158 & $49,6 \%$ & 65 \\
& pXF1.3 & 1.285 & $55,6 \%$ & 2 \\
Xf-PD & pXFPD1.3 & 1.345 & $53,0 \%$ & 2 \\
Xf-OL & pXF30 & 30.270 & $49,0 \%$ & 46 \\
Xf-AL & pXF31 & 31.572 & $49,0 \%$ & 36 \\
\hline
\end{tabular}

\begin{tabular}{l|c|c}
\hline Principais Características & Xf-OL & Xf-AL \\
\hline Tamanho Estimado (em pares de bases; pb) & 2.625 .581 & 2.434 .849 \\
\hline Seqüências Contíguas (Contigs) & 93 & 121 \\
\hline Conteúdo de Guanina/Citosina (GC\%) & $52,0 \%$ & $52,0 \%$ \\
\hline Cobertura & $\sim 8,1 \mathrm{X}$ & $\sim 9,4 \mathrm{X}$ \\
Número de ORFs Identificadas & 2.870 & 2.681 \\
\hline ORFs com provável função identificada & $1.713(62 \%)$ & $1.593(62 \%)$ \\
\hline
\end{tabular}


Xf-CVC foi isolada na cidade de Macaubal (São Paulo, Brasil) em 21 de maio de 1992, onde infectava pomares de laranjas, sendo que as plantas acometidas apresentavam sintomas típicos de CVC. Xf-PD foi isolada de videiras infectadas no condado de Temecula (Califórnia, EUA) em 1998, causando a moléstia de Pierce, que resulta em frutos sem valor comercial. XfOL e Xf-AL foram isoladas pela primeira vez no extremo sul do estado da Califórnia, EUA, em 1994, e representam os agentes etiológicos de cancro em folhas de uma espécie de planta ornamental chamada espirradeira e de amendoeiro, respectivamente (Bhattacharyya et al., 2002).

Das 2.066 ORFs identificadas em Xf-PD, um total de 2.025 (98\%) também está presente em Xf-CVC, sendo que 94,5\% das ORF compartilhadas entre estas linhagens apresentam ao menos $80 \%$ de identidade entre seus resíduos de aminoácidos, com uma média geral de 95,7\% de identidade (Van Sluys et al., 2003). Apenas 41 ORFs (1,9\%) são específicas a Xf-PD, assim como 152 ORFs (6,8\%) são para Xf-CVC. Deste grupo, mais da metade são ORFs hipotéticas ou hipotéticas conservadas, sendo algumas relacionadas a elementos genéticos móveis. Um total de 29 e 16 ORFs apresentam frameshift (FS) ou stop codon in frame (SCF) em Xf-PD e Xf-CVC, respectivamente; merece destaque a ORF que codifica para o gene precursor da poligalacturonase, intacto em Xf-PD mas com FS/SCF em Xf-CVC; este gene pode estar relacionado a processos de virulência e poderia em parte explicar a razão pela qual a Xf-PD é mais agressiva em suas interações (Van Sluys et al., 2003).

As demais diferenças entre essas linhagens consistem em 159.503 pb a mais em XfCVC e ausência de plasmídeo pXF51 em Xf-PD. Porém, apesar do alto índice de identidade de ORFs compartilhadas, a colinearidade cromossômica ao longo destas duas linhagens não é conservada (Figura 1.16A). Alinhando-se o cromossomo de Xf-CVC contra Xf-PD a partir da origem de replicação, observam-se três grandes rearranjos (translocações e inversões) cromossômicos, além de outros rearranjos pequenos (Figura 1.16B), sendo todos flanqueados em suas bordas por integrases de fagos. Xf-CVC e Xf-PD apresentam oito e quatro sítios de inserção de fagos respectivamente (Simpson et al., 2000; Van Sluys et al., 2003). Xf-OL e Xf-AL apresentam o genoma seqüenciado de forma parcial e não foi possível realizar um estudo de colinearidade entre as quatro linhagens (Bhattacharyya et al., 2002).

Xf-CVC e Xf-PD apresentam IGs específicas (Van Sluys et al., 2003). A giCVC possui 66.562 pb com conteúdo GC\% de 63,3\% e composta por 72 ORFs. Sua inserção ocorreu junto a um tRNA-Gly e apresenta uma integrase em uma de suas bordas. Merece destaque a presença de um íntron contendo uma ORF que pode codificar para uma transcriptase reversa, porém apresentando FS/SCF (Van Sluys et al., 2003). A giPD possui 15.778 pb e 61,2\% de conteúdo GC\%, carrega 6 ORFs, com destaque para uma ORF que pode expressar uma hemaglutinina, 
eventualmente relacionada ao mecanismo de interação bactéria-planta (porém também apresentando FS/SCF). Apresenta uma integrase em uma de suas bordas, e está inserida dentro do profago xpd2, sem tRNA em suas proximidades (Van Sluys et al., 2003).

Xf-CVC apresenta 209 ORFs similares a genes de fagos distribuídas em 5 regiões (xfP1, xfP2, xfP3, xfP4), denominadas regiões relacionadas a profagos. Xf-PD possui 296 ORFs similares a genes de fagos, agrupadas em 8 profagos $(x p d 1, x p d 2, x p d 3, x p d 4, x p d 5, x p d 6, x p d 7$ e $x p d 8)$,. As regiões de profagos entre Xf-CVC e Xf-PD que apresentam maior índice de identidade de aminoácidos entre suas ORFs são o profago xpd1 comparado a xfP1 e xfP2 que apresentam $83 \%$ e $78 \%$ de identidade, respectivamente. As demais regiões de profagos possuem menos de 50\% de identidade, sendo que três profagos são específicos de Xf-PD (Van Sluys et al., 2003). Foram identificadas ORFs relacionadas a processos de virulência provenientes de bactérias filogeneticamente distintas ao gênero Xylella, provavelmente provenientes de eventos de TGL, mediados pelo mecanismo de transdução do fago (Van Sluys et al., 2003).

A
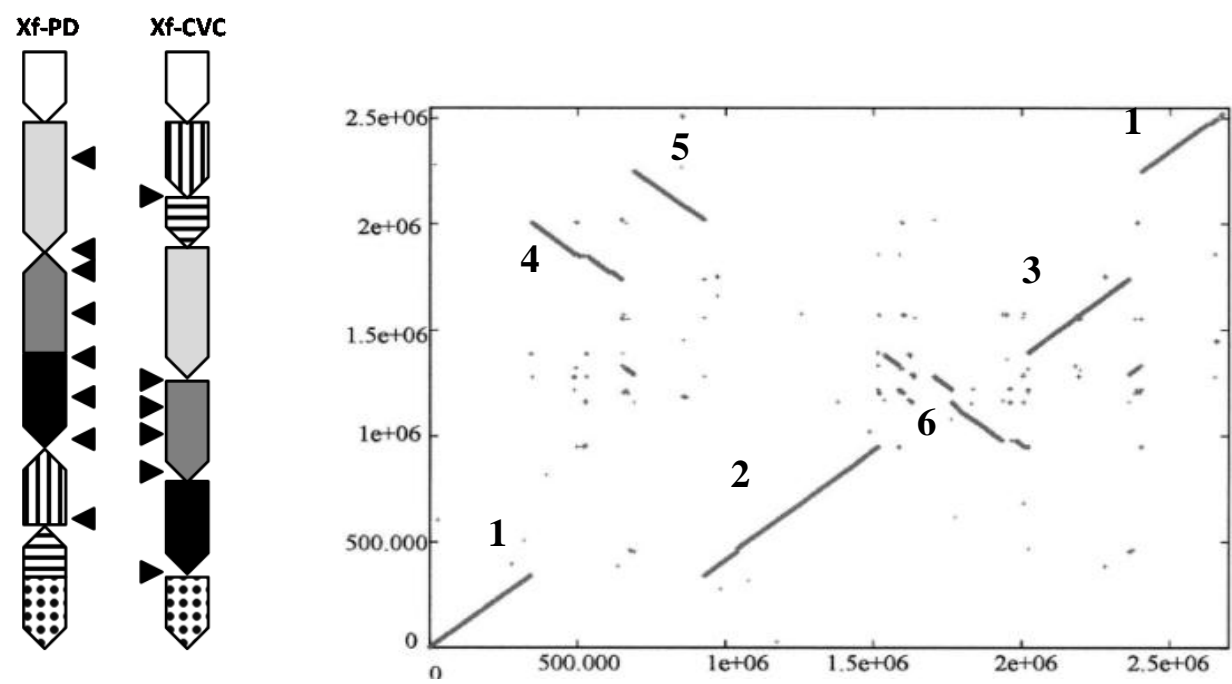

Figura 1.16. Representação esquemática das regiões colineares e alinhamento entre os cromossomos de Xf-CVC e Xf-PD. A, Detalhe (nos triângulos) da posição, tamanho e orientação de regiões colineares entre os genomas (triângulos em preto representam regiões relacionadas a profagos e ilhas genômicas). B, Alinhamento, a partir da origem de replicação, da sequiência de nucleotídeos entre as linhagens (modificado de Van Sluys et al., 2003)

As informações do seqüenciamento completo de Xf-CVC e Xf-PD demonstraram que as principais diferenças genômicas entre as linhagens estão relacionadas ao número e posição de regiões relacionadas a bacteriófagos e por inserções e deleções ocasionados pela presença de ilhas genômicas, indicando a existência de EGMs relacionados a mecanismos de TGL neste grupo de fitopatógenos (Simpson et al., 2000; Van Sluys et al., 2003). 
Além disso, mesmo com o seqüenciamento de dois genomas completos e dois parciais, o mecanismo de patogenicidade das várias linhagens de Xylella fastidiosa, nas interações (XfPlanta) e (Xf- Vetor), permanece como principal ponto de desconhecimento. Com a publicação do genoma da Xf-CVC, sugeriu-se que o envolvimento de toxinas como hemolisinas, bacteriocinas e colicinas; genes relacionados ao metabolismo de ferro; fímbrias, adesinas, hemaglutininas; genes relacionados à degradação da parede celular como endoglucanases e genes com função transportadora, estariam relacionados com o mecanismo de patogenicidade (Meidanis et al., 2002; Simpson et al., 2000; Van Sluys et al., 2002).

Assim, apesar do conhecimento amplo acerca do conteúdo genômico das linhagens de Xylella fastidiosa, várias questões relacionadas à patogenicidade, virulência, metabolismo e evolução permanecem em aberto. A questão da evolução e organização genômica e a influência dos elementos genéticos móveis no genoma de diferentes linhagens de Xf são tópicos abordados nesse trabalho. 


\section{OBJETIVOS}

O objetivo do presente trabalho é avaliar a associação de genes que codificam integrases em Xylella fastidiosa com regiões relacionadas a profagos e ilhas genômicas. Através de um estudo comparativo in silico, averiguar o envolvimento potencial destas regiões na diversificação de quatro linhagens distintas.

\subsection{OBJETIVOS ESPECÍFICOS}

Considerando-se os dados publicados pelos projetos de seqüenciamento completo de XfCVC e Xf-PD e parcial de Xf-OL e Xf-AL, os objetivos específicos foram:

- Identificar os genes com domínio Integrase;

- Classificar o domínio catalítico;

- Verificar a associação das integrases com regiões de profagos e ilhas genômicas;

- Identificar os sítios de inserção associados a tRNAs nas regiões relacionadas a profagos e ilhas genômicas;

- Analisar o padrão de agrupamento das integrases de Xylella e sua relação filogenética com integrases presentes em genomas completos de Bacteriófagos.

- Análise estrutural da organização e composição gênica das regiões relacionadas a profagos;

- Desenvolvimento de banco de dados com interface em Word Wide Web para estudos em genômica comparativa das regiões relacionadas a profagos (Ferramentas phagenavigator e phage-navigator-comparative). 


\subsection{MONTAGEM DE REGIÕES RELACIONADAS A PROFAgOS NA MOLÉCULA CANDIDATA DE Xf-AL}

A molécula candidata de Xf-AL foi montada com base nos procedimentos realizados para Xf-OL desenvolvidos no LABINFO (coordenado pela Dra Ana Tereza de Vasconcelos) em parceira com o GaTE lab. Esta montagem foi dividida em três fases.

$\underline{\mathbf{1}^{\mathrm{a}} \text { Fase: Montagem da molécula candidata de Xf-AL, exceto regiões relacionadas a profagos }}$

Nesta etapa, foi realizada a filtragem dos reads relacionados a regiões de profagos, pelo programa cross_match, através de comparação com as regiões de profagos previamente descritas em Xf-CVC e Xf-PD. Um total de 31.564 reads ou 15.782 clones (58\% do total de reads) pertencentes a regiões não relacionadas a profagos foram submetidos ao programa Phrap para buscas de similaridade e posterior agrupamento. Foram formadas 44 seqüências contíguas (contigs) com tamanho mínimo de 10.000 pb e máximo de 86.000 pb. Os programas GENSCAFF (Setubal e Werneck, 2001) e CONSED (Gordon et al., 1998) informaram a presença de 43 GAPs, sendo 24 GAPs virtuais e 23 reais. A maioria dos GAPs reais estava relacionada à proximidade de regiões de profagos, sendo que apenas 4 GAPs reais não estavam envolvidos em regiões desta natureza.

Os GAPs virtuais foram fechados incluindo-se "NNs" (notação que representa qualquer um dos quatro nucleotídeos, segundo normas IUPAC), com base em informação de posicionamento de clones, pontas de BACs e por análise comparativa contra o genoma de XfCVC e Xf-PD. A figura 3.1 ilustra um exemplo de GAP virtual na montagem de Xf-AL. Os critérios para fechamento por inserção de "NNs" nos GAPs Virtuais seguiram a seguinte ordem: (a) Quantidade mínima de cinco clones na região de GAP; (b) Presença de pontas de BACs abrangendo a região em questão; (c) Região do GAP em questão apresentar colinearidade entre as linhagens 9a5c (Xf-CVC) e Temecula1 (Xf-PD). Para fechamento dos 4 GAPs reais, foram utilizados apenas os itens (b) e (c).

Regiões que não alcançaram estes três critérios foram estudadas individualmente. A inclusão de "NNs" nestes casos foi realizada da forma mais conservadora possível, isto é, a região de GAP em estudo deveria ao menos apresentar colinearidade entre as outras linhagens e não se tratar de região relacionada ou nas proximidades de elemento genético móvel. Os 4 GAPs reais que não estavam envolvidos em regiões de profagos foram analisados contra o genoma de 
Xf-CVC e Xf-PD, onde apresentavam-se como regiões colineares, sendo portanto fechados pela inclusão de "NNs". Os demais GAPs reais serão tratados na terceira fase.

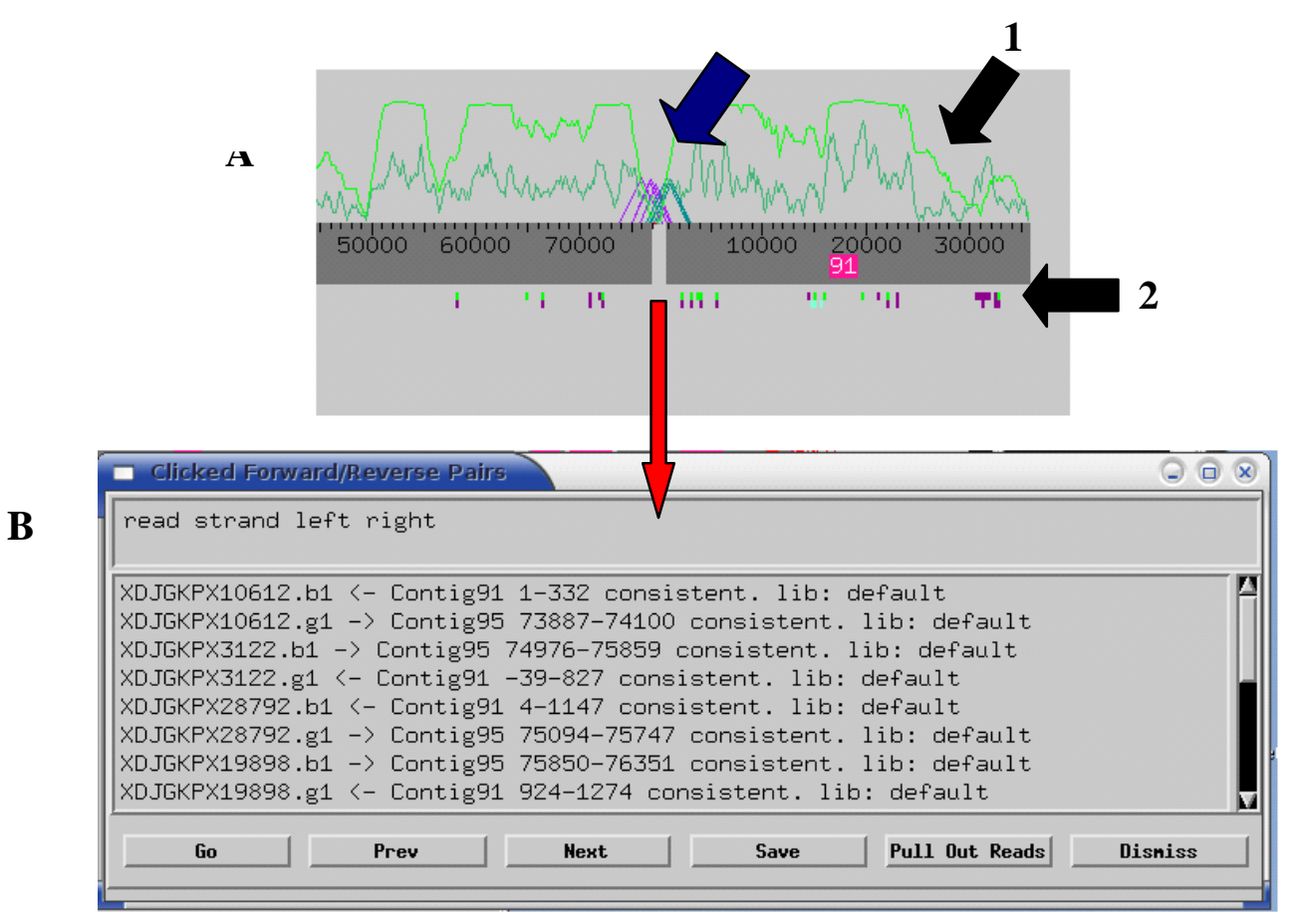

A

B

Figura 3.1. Representação de um GAP virtual, visualizado pelo programa CONSED. A, região com a presença de GAP virtual entre duas seqüências contíguas; a seta azul indica a existência de clones (representados em forma de traços verdes e vermelhos) que cobrem a região do GAP. A seta preta $\mathrm{n}^{\circ} 1$ aponta para linhas na cor verde escura (que representam a cobertura de reads do contig) e verde clara (que representam a qualidade). A seta em preto $\mathrm{n}^{\circ} 2$ informa regiões do contig contendo reads com mais de uma região possível para ancoramento (geralmente associados com regiões contendo repetições). B, Lista de clones que englobam a região do GAP em questão, informando o posicionamento e consistência. O tamanho do GAP virtual foi estimado a partir de alinhamento pelo programa cross_match frente ao genoma de Xf-CVC e Xf-PD .

$\underline{\mathbf{2}^{\mathbf{a}} \text { Fase: Montagem das regiões relacionadas a profagos em Xf-AL }}$

Nesta etapa, estabeleceu-se uma nova estratégia devido à extrema dificuldade encontrada na montagem automática destas regiões pelos procedimentos padrões. As regiões de profagos previamente descritas em Xf-CVC e Xf-PD apresentam repetições, e estas repetições configuram um complicado problema de montagem. Os programas de montagem (Phrap ou CAP3 [Huang e Madan, 1999]) não conseguem distinguir tais repetições e, no processo de montagem, ao invés de montar duas regiões repetidas, montam apenas uma região, sobrepondo e/ou colapsando as duas, e até em alguns casos mais de três regiões em apenas uma região. Devido às evidências encontradas em Xf-CVC e Xf-PD, cogitou-se que o mesmo poderia ocorrer em Xf-AL e Xf-OL. 


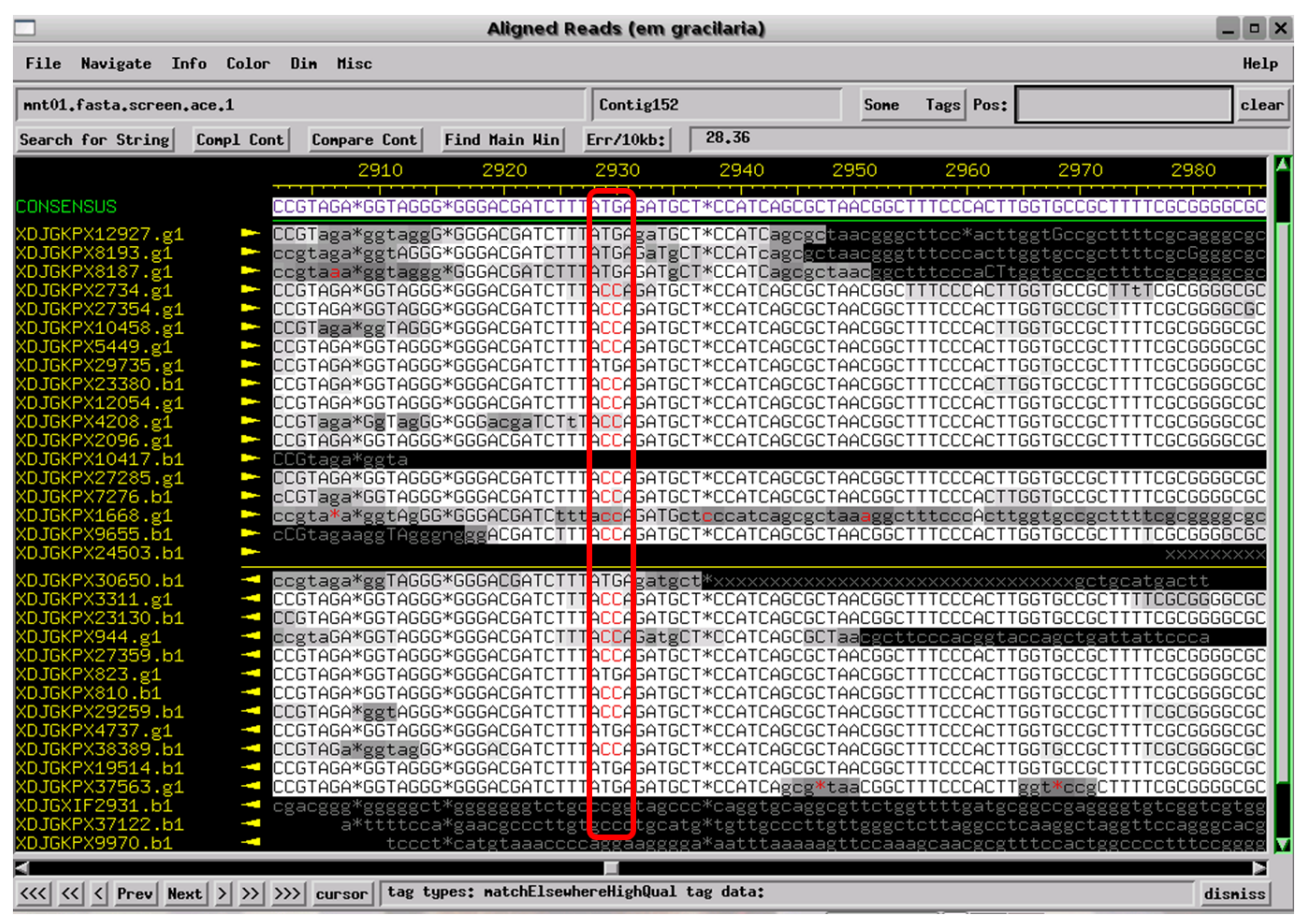

A

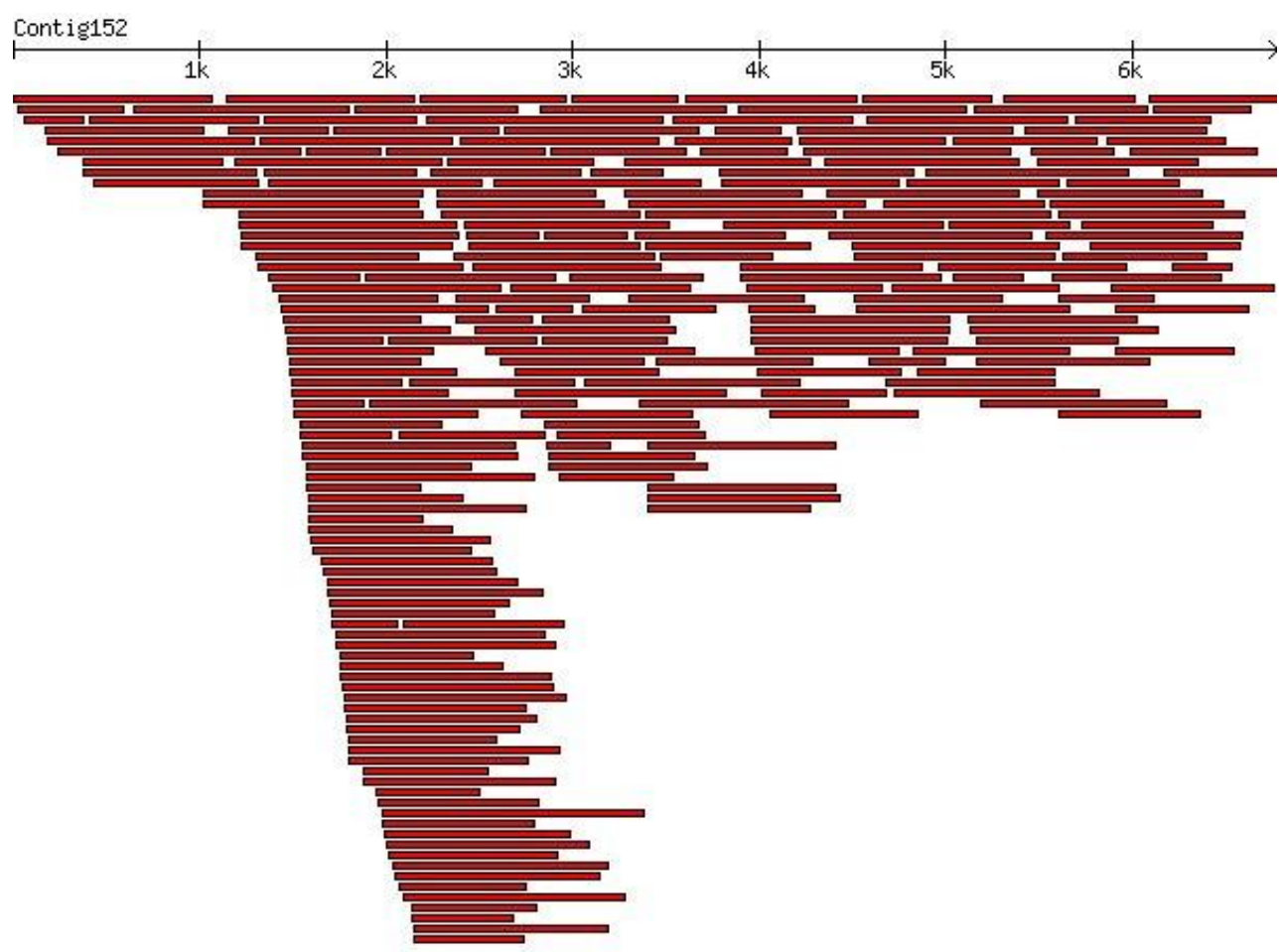

B

Figura 3.2. Representação de montagem colapsada devido à presença de repetições. As regiões relacionadas a profagos em Xf-AL apresentam grande quantidade de repetições. Neste exemplo, o contig, formado por 231 reads, possui tamanho de $6,1 \mathrm{~kb}$, quando na média um contig com essa quantidade de reads apresenta um tamanho próximo a $15 \mathrm{~kb}$; esse é o primeiro indicativo de colapso de montagem. A, Regiões com HQDs, indicando tratar-se de duas regiões colapsadas em um único contig pelo programa montador (phrap). B, Densidade de reads que compõe a montagem deste contig. Notar que o colapso das regiões ocorre entre a posição 1 kb e 3 kb. 
As primeiras tentativas de montagem das regiões de profagos em Xf-AL e Xf-OL, utilizando os procedimentos padrões dos programas, confirmou o problema, resultando em uma montagem com a formação de contigs que apresentavam grande densidade de reads em relação ao seu tamanho e, quando visualizados pelo programa CONSED, notava-se a presença de regiões com HQDs (high quality discrepancies), evidência de sobreposição de montagem. A figura 3.2 ilustra um caso típico de montagem de um contig de fagos sobreposto à sua repetição.

Portanto, em razão da dificuldade no processo de montagem das regiões de profagos (pela presença de repetições), uma nova forma de montagem teve que ser pensada para desenvolvimento deste projeto. A solução foi a criação de uma ferramenta de bioinformática a partir de modificações do código fonte do programa SABIÁ (System for Automated Bacterial Integrated Annotation) (Almeida et al., 2004a). Esta ferramenta, denominada "Phage Navigator Assembly", foi escrita na linguagem de programação PHP (http://www.php.net) e PERL (http://www.perl.com), utilizando o banco de dados mySQL (http://www.mysql.com). Esta ferramenta permitiu esclarecer a quantidade de contigs e os scaffolds das regiões de profagos e também das repetições sobrepostas em um único contig, para posterior análise manual da montagem e inclusão de "NNs" em regiões de GAPs, conforme descrito na fase anterior.

Seguiram-se os mesmos critérios adotados na fase anterior de montagem; porém, para evitar a montagem de seqüências contínuas discrepantes e sobrepostas, foi executada a montagem pela inclusão de clone a clone, individualmente e de forma incremental, uma técnica denominada "clone walking” (Figura 3.3). O incremento na montagem foi feito utilizando-se os últimos 500 pb na ponta de cada contig como material para comparação no banco de reads de seqüências de profagos. A inclusão de clones foi determinada pelo programa cross_match com os seguintes parâmetros: minmatch 30; minscore 50. Nesse processo, foram utilizados dois programas de montagem (phrap e CAP3); em razão dos diferentes algoritmos de cada programa, em alguns casos contigs colapsados pelo phrap são montados corretamente com o CAP3, desta forma estabelecendo um meio de solucionar a montagem de regiões colapsadas e discrepantes. No total, foram submetidos ao processo de montagem 23.046 reads ou 11.523 clones (42\% do total de reads) relacionados a regiões de fagos.

Como esta metodologia envolvia um passo de inspeção visual a cada nova montagem para incremento do contig, os reads que configuravam polimorfismos de base única (SNPs), discrepâncias de alta qualidade (HQD) e baixa qualidade (LQD) foram excluídos individualmente a fim de evitar a formação de contigs discrepantes, ou seja, contendo reads que pertenciam a priori a outra posição do genoma. 


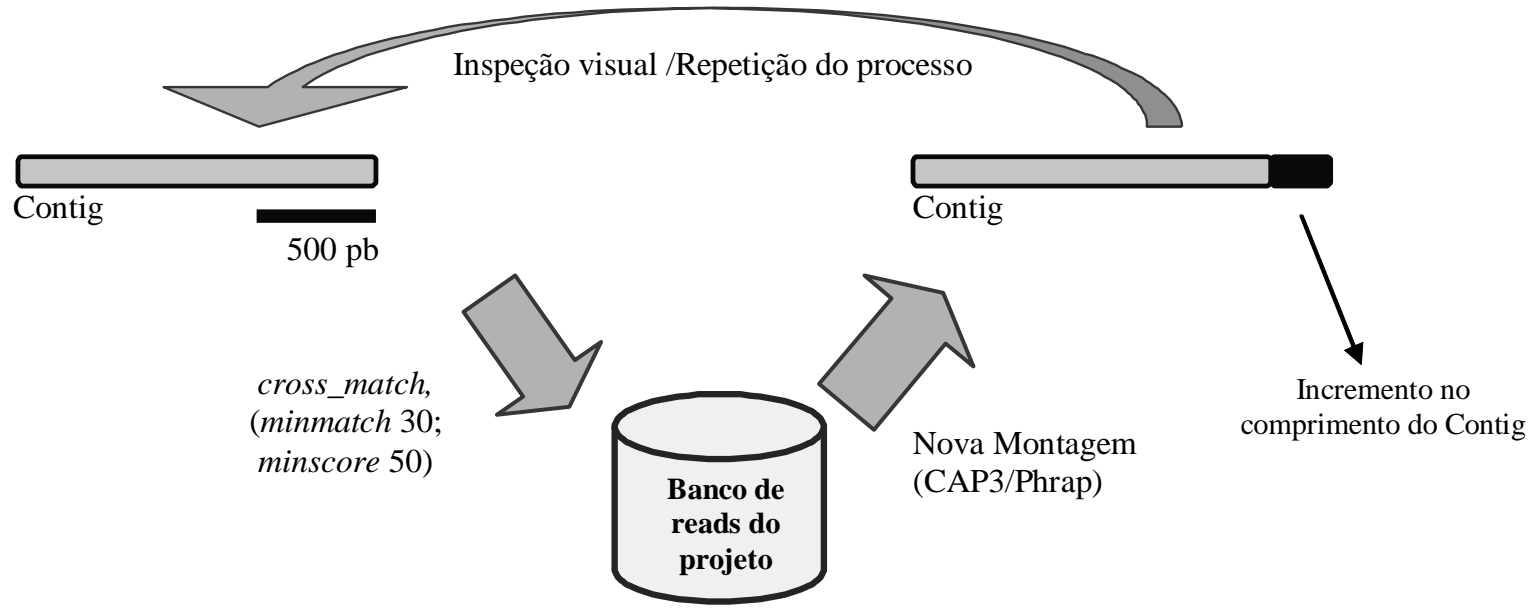

Figura 3.3. Esquema da metodologia de "clone-walking" utilizada para montagem das regiões de profagos em XfAL.

$\underline{3^{a} \text { Fase: União da montagem de regiões de profagos com a montagem do cromossomo }}$

Nesta etapa, realizou-se a união das seqüências contínuas (contigs) geradas nas fases anteriores, com finalidade de recuperar a molécula candidata de Xf-AL. Posteriormente, foi feita a análise do resultado final de montagem por metodologia de GC-Skew e mapeamento de todas as regiões cobertas por "NNs" no procedimento de montagem (este mapeamento pode ser visualizado no Anexo IV), para futura etapa de finalização (finishing) das moléculas candidatas (que, no entanto, não é escopo deste trabalho). Para esta fase, utilizaram-se exclusivamente os programas cross_match e CONSED.

Uma análise detalhada sobre o procedimento de montagem das moléculas candidatas de Xf-OL e Xf-AL está apresentada no Anexo I.

\subsection{CARACTERIZAÇÃO DAS INTEGRASES DE FAGO: DISTRIBUIÇÃO, CLASSIFICAÇÃO E DOMÍNIO CATALÍTICO}

Os programas utilizados para identificação das integrases nos genomas das linhagens de Xf foram cross_match (Ewing e Green, 1998) e BLAST (Basic Local Alignment Search Tool) (Altschul et al., 1997) e os bancos de dados PFAM (Sonnhammer et al., 1997) e Swiss-Prot (Bairoch e Boeckmann, 1994). Para classificação, foram utilizados os programas CLUSTALX 2.0 (Thompson et al., 1994), MUSCLE (Edgar, 2004), GENEDOC (Nicholas et al., 1997) e BioEDIT (Hall, 1999) e métodos de inferências filogenéticas pelo algoritmo de Neighbor-joining 
(Saitou e Nei, 1987), com um teste de bootstrap de 1000 réplicas e exclusão de posições com gaps. As análises filogenéticas foram conduzidas com os programas MEGA 4.0 (Kumar et al., 2004) e PHYLIP 3.6 (Felsenstein, 2005). As análises de network foram adaptadas das metodologias descritas para o programa InterView (Holden et al., 2007), onde as inter-relações entre seqüências de proteínas foram determinadas pelo programa BLASTP com e-value de $\mathrm{e}^{-05}$, e distâncias calculadas pelo programa PROTDIST (Felsenstein, 2005) utilizando-se matriz Jones Taylor Thornton (JTT).

A análise do domínio, tirosina ou serina recombinase, foi realizada seguindo modelo proposto por Groth e Calos (2004), por inspeção visual dos resíduos de aminoácidos, nas regiões responsáveis pela atividade enzimática, com a utilização dos bancos PDB (Protein Data Bank) (Kouranov et al., 2006), INTERPRO (Mulder et al., 2007) e CDD (Conserved Domain Database) (Marchler-Bauer et al., 2005). As tabelas 3.1 e 3.2 apresentam os domínios de integrases identificados nos bancos InterPRO e CDD e utilizados neste trabalho.

Tabela 3.1 Domínios identificados para as tirosinas e serinas recombinases, pelo banco InterPro.

\begin{tabular}{c|c|c|l}
\hline \multicolumn{2}{l}{ Domínios InterPro das Tirosinas Recombinases } \\
\hline Domínio & Banco associado & Nome & \multicolumn{1}{c}{ Descrição } \\
\hline IPR011010 & SSF56349 & DNA_brk_join_enz & $\begin{array}{l}\text { Enzima de quebra e re-ligação do DNA, domínio } \\
\text { catalítico. }\end{array}$ \\
\hline IPR010998 & SSF47823 & L_intgrse_like_N & Integrase do fago lambda, domínio N-terminal. \\
\hline IPR002104 & PF00589 & Phage_integrase & Integrases de fago, domínio catalítico \\
\hline IPR013762 & G3DSA:1.10.443.10 & Phage_intgr_like & Integrases de fago, domínio catalítico \\
\hline
\end{tabular}

\begin{tabular}{l|c|c|l}
\hline \multicolumn{2}{l}{ Domínios InterPro das Serinas Recombinases } \\
\hline IPR006118 & $\begin{array}{l}\text { PS00397 } \\
\text { PS00398 }\end{array}$ & $\begin{array}{l}\text { RECOMBINASES_1 } \\
\text { RECOMBINASES_2 }\end{array}$ & $\begin{array}{l}\text { Recombinase sítio-específica, família resolvase, } \\
\text { domínio catalítico N-terminal e domínio HTH C- } \\
\text { terminal. }\end{array}$ \\
\hline IPR006119 & PF00239 & Resolvase & Resolvase, domínio N-terminal \\
\hline IPR006120 & PF02796 & HTH_7 & $\begin{array}{l}\text { Domínio HTH (helix-turn-helix) das resolvases, C- } \\
\text { terminal. }\end{array}$ \\
\hline
\end{tabular}

Para o estudo da distribuição das integrases de fagos e regiões de profagos, foi modificada uma ferramenta de bioinformática (utilizada pelos projetos genomas do grupo AEG/FAPESP), que ilustra na forma de mapa genômico o posicionamento de cada ORF, indicando a posição de cada região relacionada a fago. Esta ferramenta foi escrita na linguagem de programação PERL (http://www.perl.com), e seu resultado pode ser visualizado em http://gracilaria.ib.usp.br/integraseDB. 
Tabela 3.2 Domínios identificados para as tirosinas e serinas recombinases, pelo banco CDD.

\section{Domínios CDD das Tirosinas Recombinases}

Todos os domínios fazem parte de superfamília de enzimas de quebra e re-ligação de DNA, onde as tirosinas recombinases se encontram. Nessa classe de enzimas, o sítio catalítico conservado está na região C-terminal, enquanto a região N-terminal é variável, e pode ser responsável por outras atividades (geralmente de ligação a DNA).

\begin{tabular}{|c|c|c|}
\hline Domínio & Nome & Descrição \\
\hline $\operatorname{cd} 00397$ & DNA_BRE_C & $\begin{array}{l}\text { Domínio geral das enzimas de quebra e re-ligação do DNA, incluindo tirosinas } \\
\text { recombinases e topoisomerases tipo IB. O mecanismo de ação envolve a } \\
\text { clivagem de DNA simples fita pelo ataque nucleofílico de uma tirosina catalítica, } \\
\text { gerando adutos DNA-proteína 3'-fosfotirosil, que são atacados então por um } \\
\text { terminal 5'-hidroxil, gerando DNA dupla-fita. }\end{array}$ \\
\hline $\operatorname{cd} 01182$ & INT_REC_C & $\begin{array}{l}\text { Domínio geral das integrases/recombinases com atividade de quebra e re-ligação } \\
\text { do DNA. Membros incluem integrase do fago lambda, recombinases Cre e } \\
\text { XerCD. }\end{array}$ \\
\hline $\operatorname{cd} 00798$ & INT_XerDC & $\begin{array}{l}\text { Integrases XerC e XerD, domínios N- e C-terminais. Integrases envolvidas na } \\
\text { integração e excisão de bacteriófagos lisogênicos, transposição de transposons } \\
\text { conjugativos e herança plasmidial estável no genoma hospedeiro. }\end{array}$ \\
\hline COG0582 & $\mathrm{XerC}$ & Tirosina recombinase XerC \\
\hline PRK00236 & XerC & Tirosina recombinase XerC \\
\hline PRK00283 & XerD & Tirosina recombinase XerD \\
\hline $\operatorname{cd} 00796$ & INT_Rci & $\begin{array}{l}\text { Recombinase Rci, domínio catalítico C-terminal. Encontradas em plasmídeos } \\
\text { Incl1. A recombinase do plasmídeo R64 promove recombinação de segmentos de } \\
\text { DNA altamente móveis (shufflon) encontrados na região C-terminal do gene pilV } \\
\text { (envolvido em conjugação). }\end{array}$ \\
\hline cd00799 & INT_Cre & $\begin{array}{l}\text { Recombinase Cre, domínio catalítico C-terminal. Promove a recombinação sítio- } \\
\text { específica entre dois sítios loxP. }\end{array}$ \\
\hline $\operatorname{cd} 00797$ & HP1_INT_C & $\begin{array}{l}\text { Integrase do fago HP1, domínio catalítico C-terminal. Promove a recombinação } \\
\text { entre o DNA cromossomal da bactéria e o genoma do HP1. }\end{array}$ \\
\hline $\operatorname{cd} 00800$ & INT_Lambda_C & $\begin{array}{l}\text { Integrase do fago lambda, domínio catalítico C-terminal. Realiza integração e } \\
\text { excisão de fagos temperados e outros elementos genéticos móveis presentes nos } \\
\text { genomas bacterianos. }\end{array}$ \\
\hline $\operatorname{cd} 00801$ & INT_P4 & $\begin{array}{l}\text { Integrase do fago P4. Encontradas em fagos temperados, plasmídeos integrativos, } \\
\text { ilhas genômicas e outros elementos genéticos móveis. Promove a recombinação } \\
\text { entre dois sítios (chamados sítios de ligação) presentes no cromossomo } \\
\text { bacteriano (e geralmente associados a um tRNA) e no genoma do fago } \\
\text { (geralmente, próximos à integrase). }\end{array}$ \\
\hline cd01192 & INT_P22_C & Integrase do fago P22, domínio catalítico C-terminal. \\
\hline PRK09692 & INT_CP4 & Integrase do fago CP4 \\
\hline $\operatorname{cd} 01185$ & INT_Tn4399 & $\begin{array}{l}\text { Integrase do transposon Tn4399 (transposon mobilizável de Bacteroidetes), } \\
\text { domínios N- e C-terminais. }\end{array}$ \\
\hline cd01190 & INT_SG5 & Integrases/recombinases do subgrupo 5, domínios N- e C-terminais. \\
\hline
\end{tabular}

\section{Domínios CDD das Serinas Recombinases}

Domínios presentes nas famílias das resolvases, invertases, integrases e transposases. O sítio catalítico conservado está na região N-terminal, enquanto a região C-terminal é responsável pela ligação a DNA. Essas enzimas catalisam a recombinação sítio-específica por um mecanismo de quebra e re-ligação das 4 fitas de DNA, ao mesmo tempo, em um passo que envolve uma ligação fosfoserina transiente entre o DNA e a enzima.

\begin{tabular}{c|c|l}
\hline Domínio & Nome & \multicolumn{1}{c}{ Descrição } \\
\hline cd03768 & SR_ResInv & $\begin{array}{l}\text { Família das serinas recombinases, subfamília das invertases/resolvases, domínio } \\
\text { catalítico. }\end{array}$ \\
\hline cd00338 & Ser_Recombinase & Família das serinas recombinases, domínio catalítico. \\
\hline pfam00239 & Resolvase & $\begin{array}{l}\text { Resolvase, domínio N-terminal. Esse domínio contém o sítio ativo e a interface } \\
\text { para o dímero. }\end{array}$ \\
\hline pfam02796 & HTH_7 & Domínio HTH (helix-turn-helix) das resolvases, C-terminal \\
\hline
\end{tabular}




\subsection{FERRAMENTAS "PHAGE NAVIGATOR" E "PHAGE NAVIGATOR COMPARATIVE" E O BANCO DE DADOS "INTEGRASE_DB"}

Duas ferramentas foram originadas nesse projeto, "Phage navigator" e "Phage navigator comparative", a partir de modificações do código fonte do programa SABIÁ Comparative (Almeida et al., 2004b) e tiveram como objetivos: (a) análise comparativa das regiões de profagos; e (b) análise da associação de integrases com profagos e ilhas genômicas.

Para identificação de regiões de profagos, foram utilizados os programas prophage_finder (Bose e Barber, 2006) e phage_Finder (Fouts, 2006) com os critérios: (a) Região candidata com tamanho mínimo de 10.000 pb (não foi estabelecido um tamanho máximo); (b) Presença de mais de $80 \%$ de ORFs na região candidata com função relacionada a fagos; (c) Inspeção manual de cada região selecionada em a) e b) a fim de excluir falsos positivos. Do mesmo modo, para evitar falsos negativos, procedeu-se uma busca em regiões próximas a tRNAs e integrases que no processo anterior não foram associadas a uma região candidata, sendo utilizado o programa tRNAscan-SE (Lowe e Eddy, 1997) para a identificação dos tRNAs. Regiões que não alcançaram esses critérios foram analisadas individualmente a fim de identificar e catalogar regiões que nesse trabalho foram classificadas como "regiões remanescentes".

Phage Navigator compreende um conjunto de scripts na linguagem de programação PHP utilizando banco de dados em mySQL, modificado a partir da ferramenta de anotação SABIÁ. Através desta ferramenta, é possível acessar informações acerca do conteúdo de ORFs dos fagos, sítios de inserção, e visualização em forma de mapas genômicos gerados por scripts em PERL, adaptados do programa de mapa genômico do grupo AEG. Esta ferramenta pode ser acessada pelo endereço do projeto do banco de dados: http://gracilaria.ib.usp.br/integraseDB.

Phage Navigator Comparative também foi modificado a partir do código fonte da ferramenta SABIÁ Comparative (Almeida et al., 2004b), com a finalidade de análise genômica comparativa de todos os genes de fagos, em especial as integrases, pela metodologia de BBH (Bi-direcional Best Hit) (Overbeek et al., 1999). A estrutura do banco de dados do SABIÁ Comparative foi adaptada para comportar a entrada de genomas de fagos. Foram utilizados para a comparação 402 genomas de fagos depositados no GenBank (http://www.ncbi.nlm.nih.gov/ genomes/static/phg.html) até a data de 18/06/2007. Os parâmetros para construção dos BBHs foram: mínimo de $60 \%$ de cobertura de alinhamento e $e$-value de 0.00001 . A lista completa dos 402 genomas de fagos utilizados pode ser acessada pela própria ferramenta no seguinte 
endereço: http://gracilaria.ib.usp.br/integraseDB/webpage/services/phage_navigator_ comparative/pnc_prod/orgs_table.html.

Para determinação do conjunto de genes essenciais de bacteriófagos, a fim de definir quais fagos de Xf estariam completos, as ORFs identificadas nas regiões de profagos foram categorizadas funcionalmente conforme apresentado na tabela 3.3. Esta categorização funcional foi elaborada especificamente para este projeto e utilizada pelas ferramentas Phage Navigator e Phage Navigator Comparative.

As análises comparativas entre os quatro genomas e de suas regiões de profagos foram conduzidas com os programas M-GCAT (Treangen e Messeguer, 2006) e MUMmer (Delcher et al., 2002), sendo as figuras e imagens trabalhadas pelos programas GIMP (http://www.gimp.org) e Inkscape (http://www.inkscape.org). Demais análises computacionais foram realizadas com o pacote de programas EMBOSS (Olson, 2002).

O banco de dados "Integrase_DB" foi desenvolvido em linguagem HTML (HyperText Markup Language) e PHP para acesso em forma de página de internet, sendo as informações guardadas no banco de dados mySQL. A interface é acessível pelo seguinte endereço: http://gracilaria.ib.usp.br/integraseDB, mediante uso de uma senha de acesso.

Tabela 3.3. Categorias funcionais utilizadas pela ferramenta Phage-Navigator e Phage-Navigator Comparative.

\begin{tabular}{l|l}
\hline \multicolumn{1}{c|}{ Categoria } & \multicolumn{1}{c}{ Descrição } \\
\hline & A- Função Integrase \\
& B- Função Lisozima \\
& C- Função Helicase e ligação ao DNA \\
& D- Função DNA polimerase e metilase \\
& E- Função regulatória da transcrição (repressor e anti-repressor) \\
& F- Função relacionada a genes estruturais \\
& G- Função desconhecida associada a fagos \\
\hline \multirow{2}{*}{ Genes não essenciais para fagos } & A- Genes não associados a fagos \\
& B- Funções relacionadas à patogenicidade e virulência \\
\hline \multirow{2}{*}{ Hipotéticas / Hipotéticas Conservadas } & A- Hipotética \\
& B- Hipotética Conservada \\
\hline
\end{tabular}




\section{RESULTADOS}

\subsection{IDENTIFICAÇÃO DO NÚMERO, ASSOCIAÇÃO E DISTRIBUIÇÃO DAS INTEGRASES DE PROFAGOS}

Nos últimos 10 anos, a comunidade científica tem se apoiado em três metodologias básicas para identificação de ORFs nos genomas seqüenciados, sejam eles pertencentes a espécies de Bacteria, Archaea ou Eukarya: (a) identificação de quadros abertos de leitura; (b) busca por ortólogos com base na similaridade, em banco de dados nucleotídicos ou protéicos, e (c) utilização de métodos matemáticos e probabilísticos, como Cadeias Ocultas de Markov (HMM) (Brent, 2005). Com base nestas metodologias, foram analisados os genomas completos de duas linhagens (Xf-CVC e Xf-PD) e moléculas candidatas de outras duas linhagens (Xf-AL e Xf-OL) de Xylella fastidiosa, em busca de ORFs cujo melhor alinhamento tenha se dado com proteínas integrases depositadas em bancos de dados relacionados.

Ao todo, 56 genes que potencialmente codificam para integrases foram identificados em Xf. As proteínas preditas se apresentam em três formas distintas, conforme listado na tabela 4.1: (a) forma completa potencialmente funcional, apresentando aproximadamente 325 resíduos de aminoácidos (segundo o banco de dados PFAM, número de acesso PF00589); (b) forma completa apresentando FS/SCF (frameshift / stop codon in frame); e (c) forma incompleta (ou fragmentos), isto é, apresentando tamanho menor que 280 resíduos de aminoácidos (valor arbitrário atribuído nesse trabalho). Todas as integrases identificadas estão associadas e contidas dentro de regiões de profagos e IGs ou dispersas no cromossomo em regiões classificadas como 'remanescentes de profagos' (Tabela 4.2). Xf-CVC apresenta 14 integrases, sendo 7 completas, 2 em FS/SCF e 5 fragmentos; Xf-PD apresenta 12 integrases, sendo 7 completas, 3 em FS/SCF e 2 fragmentos; Xf-OL apresenta 13 integrases, sendo 9 completas, 3 em FS/SCF e 1 fragmento; XfAL apresenta 17 integrases, sendo 10 completas, 2 em FS/SCF e 5 fragmentos. A tabela 4.1 lista todas as ORFs cujos produtos preditos são integrases, com sua respectiva posição genômica, domínio catalítico e a qual EGM (profago ou IG) está associada, e a tabela 4.2 complementa as informações, indicando as principais características das regiões relacionadas a profagos e IGs. 
Tabela 4.1 Identificação de integrases de fagos e IGs nas quatro linhagens de Xf *

\begin{tabular}{|c|c|c|c|c|c|}
\hline Linhagem & $\begin{array}{c}\text { Nomenclatura / } \\
\text { Observações }\end{array}$ & $\begin{array}{l}\text { Coordenadas } \\
\text { Genômicas }\end{array}$ & Tamanho (bp) & Fago / IG & Assinatura \\
\hline \multirow[t]{14}{*}{ Xf-CVC } & xfp6 & $487.057 \ldots 488.367$ & 1.311 & xfp6 & Tirosina \\
\hline & cve-r1 & $607.242 \ldots 608.483$ & 1.242 & cve-r1 & Tirosina \\
\hline & xfp1 & $649.115 \ldots 650.278$ & 1.164 & xfp1 & Tirosina \\
\hline & cvc-r2_frag (fragmento) & $926.826 \ldots 927.659$ & 834 & cve-r2 & Tirosina \\
\hline & $\mathrm{xfp} 3(\overline{\mathrm{FS}} / \mathrm{SCF})$ & $1.514 .347 \ldots 1.515 .383$ & 1.020 & xfp3 & Tirosina \\
\hline & xfp4 & $1.585 .980 \ldots 1.586 .999$ & 1.020 & $\mathrm{xfp} 4$ & Tirosina \\
\hline & giCVC & $1.638 .946 \ldots 1.640 .907$ & 1.962 & giCVC & Tirosina - INT-CP4 \\
\hline & giCVC_frag (fragmento) & $1.673 .842 \ldots 1.674 .468$ & 626 & giCVC & Não determinado \\
\hline & giCVC_frag_2 (fragmento) & $1.705 .455 \ldots 1.705 .613$ & 159 & giCVC & Não determinado \\
\hline & xfp5 (FS/ SCF) & $2.021 .351 \ldots 2.022 .372$ & 1.020 & xfp5 & Tirosina \\
\hline & cve-r4 & $2.177 .071 \ldots 2.178 .132$ & 1.062 & cve-r4 & Tirosina \\
\hline & xfp2_frag (fragmento) & $2.361 .085 \ldots 2.361 .492$ & 408 & $\mathrm{xfp} 2$ & Não determinado \\
\hline & $\mathrm{xfp} 2$ & $2.403 .249 \ldots 2.404 .268$ & 1.020 & $\mathrm{xfp} 2$ & Tirosina \\
\hline & cvc_r3_frag (fragmento) & $2.653 .288 \ldots 2.653 .572$ & 285 & cve-r3 & Não determinado \\
\hline \multirow[t]{12}{*}{ Xf-PD } & $\mathrm{xpd} 3$ & $466.592 \ldots 467.611$ & 1.020 & $\mathrm{xpd} 3$ & Tirosina \\
\hline & pd-r1 & $946.367 \ldots 947.386$ & 1.020 & pd-r1 & Tirosina \\
\hline & giPD & $1.194 .756 \ldots 1.195 .988$ & 1.233 & giPD & Tirosina - INT-CP4 \\
\hline & $\mathrm{xpd} 2$ & $1.216 .888 \ldots 1.217 .907$ & 1.020 & xpd2 & Tirosina \\
\hline & xpd1_2 & $1.276 .043 \ldots 1.277 .374$ & 1.332 & xpd1_2 & Tirosina \\
\hline & xpd1_frag (fragmento) & $1.279 .530 \ldots 1.279 .742$ & 213 & xpd1 & Não determinado \\
\hline & xpd1 & $1.330 .522 \ldots 1.331 .541$ & 1.020 & xpd1 & Tirosina \\
\hline & xpd4 & $1.391 .744 \ldots 1.392 .763$ & 1.020 & xpd4 & Tirosina \\
\hline & xpd6 (FS/SCF) & $1.548 .922 \ldots 1.549 .963$ & 1.041 & xpd6 & Tirosina \\
\hline & pd-r2 (fragmento) & $1.737 .843 \ldots 1.738 .253$ & 411 & pd_r2 & Não determinado \\
\hline & xpd8 (FS/SCF) & $1.855 .876 \ldots 1.857 .049$ & 1.173 & $\mathrm{xpd} 8$ & Tirosina \\
\hline & xpd7 (FS/SCF) & $2.019 .327 \ldots 2.020 .421$ & 1.094 & xpd7 & Tirosina \\
\hline \multirow[t]{13}{*}{ Xf-OL } & xop2 & $765.492 \ldots 766.553$ & 1.062 & xop2 & Tirosina \\
\hline & xop3 & $931.782 \ldots 932.843$ & 1.063 & xop3 & Tirosina \\
\hline & xop4 & $1.090 .793 \ldots 1.091 .812$ & 1.020 & xop4 & Tirosina \\
\hline & xop5 & $1.180 .934 \ldots 1.181 .911$ & 978 & xop5 & Tirosina \\
\hline & xop6_1 & $1.271 .654 \ldots 1.272 .781$ & 1.128 & xop6 & Tirosina \\
\hline & xop6_2 & $1.311 .474 \ldots 1.312 .658$ & 1.185 & xop6 & Tirosina \\
\hline & xop7 (FS/SCF) & $1.387 .712 \ldots 1.388 .730$ & 1.018 & xop7 & Tirosina \\
\hline & xop7_frag (fragmento) & $1.410 .241 \ldots 1.411 .068$ & 828 & xop7 & Tirosina \\
\hline & ol-r1 (FS/SCF) & $1.616 .985 \ldots 1.618 .004$ & 1.019 & ol-r1 & Tirosina \\
\hline & xop10 & $1.703 .261 \ldots 1.704 .322$ & 1.062 & xop10 & Tirosina \\
\hline & xop8 (FS/SCF) & $2.015 .770 \ldots 2.017 .047$ & 1.277 & xop8 & Tirosina \\
\hline & xop8 & $2.036 .592 \ldots 2.037 .611$ & 1.020 & xop8 & Tirosina \\
\hline & xop9 & $2.124 .338 \ldots 2.125 .432$ & 1.095 & xop9 & Tirosina \\
\hline \multirow[t]{17}{*}{$\mathbf{X f - A L}$} & xap1 & $203.963 \ldots 204.982$ & 1.020 & xap1 & Tirosina \\
\hline & xap1_frag (fragmento) & $245.178 \ldots 245.585$ & 408 & xap1 & Não determinado \\
\hline & xap2 & $585.243 \ldots 586.262$ & 1.020 & xap2 & Tirosina \\
\hline & xap3 & $856.059 \ldots 857.078$ & 1.020 & xap3 & Tirosina \\
\hline & xap10_frag (fragmento) & $1.001 .238 \ldots 1.002 .068$ & 831 & xap10 & Tirosina \\
\hline & xap4_2 & $1.074 .035 \ldots 1.075 .345$ & 1.311 & xap4 & Tirosina \\
\hline & xap4_1 & $1.093 .112 \ldots 1.094 .185$ & 1.074 & xap4 & Tirosina \\
\hline & al-r3 & $1.261 .633 \ldots 1.262 .865$ & 1.233 & al-r3 & Tirosina \\
\hline & xap5_frag (fragmento) & $1.300 .648 \ldots 1.301 .259$ & 612 & xap5 & Não determinado \\
\hline & xap5 & $1.302 .172 \ldots 1.303 .332$ & 1.165 & xap5 & Tirosina \\
\hline & xap6 & $1.621 .068 \ldots 1.622 .087$ & 1.020 & xap6 & Tirosina \\
\hline & al-r1_frag (fragmento) & $1.681 .777 \ldots 1.682 .148$ & 372 & al-r1 & Não determinado \\
\hline & xap7 & $1.759 .838 \ldots 1.760 .857$ & 1.020 & xap7 & Tirosina \\
\hline & al_r2_FS (FS/SCF) & $1.909 .860 \ldots 1.910 .882$ & 1.020 & al_r2 & Tirosina \\
\hline & xap9 (FS/SCF) & $2.084 .289 \ldots 2.085 .210$ & 921 & xap9 & Tirosina \\
\hline & xap9 & $2.128 .347 \ldots 2.129 .540$ & 1.194 & xap9 & Tirosina \\
\hline & xap11_frag (fragmento) & $2.605 .021 \ldots 2.605 .305$ & 285 & xap11 & Não determinado \\
\hline
\end{tabular}

* A nomenclatura atribuída para cada integrase é semelhante à nomenclatura da região relacionada a profago, remanescentes ou IG a qual está associada. 
Tabela 4.2 Identificação de regiões relacionadas a profagos e IGs nas quatro linhagens de Xf

\begin{tabular}{|c|c|c|c|c|}
\hline Xf-CVC & Tamanho (pb) & GC\% & ORFs & Coordenadas Genômicas \\
\hline xfp1 & 42.178 & 57,0 & 54 & $648.815 \ldots 691.593$ \\
\hline xfp2 & 43.708 & 57,0 & 58 & $2.360 .260 \ldots 2.404 .668$ \\
\hline xfp3 & 26.940 & 58,0 & 44 & $1.514 .047 \ldots 1.541 .687$ \\
\hline xfp4 & 45.930 & 55,0 & 69 & $1.585 .480 \ldots 1.631 .556$ \\
\hline xfp5 & 18.184 & 56,0 & 31 & $2.003 .888 \ldots 2.022 .672$ \\
\hline xfp6 & 43.585 & 58,0 & 57 & $486.557 \ldots 530.942$ \\
\hline giCVC & 67,058 & 66,0 & 78 & $1.638 .517 \ldots 1.705 .575$ \\
\hline cve-r1 & 14,946 & 55,0 & 8 & $600.874 \ldots 615.820$ \\
\hline cvc-r2 & 1,682 & 53,0 & 1 & $926,826 \ldots 928,508$ \\
\hline cve-r3 & 6,919 & 54,0 & 13 & $2.535 .339 \ldots 2,546.406$ \\
\hline cve-r4 & 14,561 & 43,0 & 20 & $1.777 .003 \ldots 1,791.564$ \\
\hline cve-r5 & 16,819 & 54,0 & 22 & $2.177 .071 \ldots 2,193.890$ \\
\hline Xf-PD & Tamanho (pb) & GC\% & ORFs & Coordenadas Genômicas \\
\hline xpd1 & 55.498 & 55,0 & 76 & $1.275 .043 \ldots 1.331 .941$ \\
\hline xdp2 $§$ & 62.087 & 57,0 & 85 & $1.155 .491 \ldots 1.218 .042$ \\
\hline giPD & 15.698 & 62,8 & 7 & $1.180 .707 \ldots 1.196 .405$ \\
\hline xpd3 & 13.911 & 56,0 & 22 & $453.607 \ldots 468.384$ \\
\hline xpd4 & 16.295 & 57,0 & 24 & $1.376 .361 \ldots 1.392 .833$ \\
\hline xpd5 & 24.192 & 43,0 & 41 & $1.117 .991 \ldots 1.142 .683$ \\
\hline xpd6 & 27.651 & 52,0 & 45 & $1.548 .922 \ldots 1.576 .573$ \\
\hline xpd7 & 17.795 & 54,0 & 29 & $2.002 .926 \ldots 2.020 .821$ \\
\hline xpd8 & 15.302 & 59,0 & 21 & $1.845 .748 \ldots 1.861 .050$ \\
\hline pd-r1 & 6,613 & 58,0 & 8 & $946.370 \ldots 952.983$ \\
\hline pd-r2 & 407 & 53,0 & 1 & $1.737 .843 \ldots 1.738 .250$ \\
\hline Xf-OL & Tamanho (pb) & GC\% & ORFs & Coordenadas Genômicas \\
\hline xop1 & 17.201 & 56,0 & 24 & $449.722 \ldots 467.735$ \\
\hline xop2 & 32.742 & 57,0 & 39 & $765.192 \ldots 798.534$ \\
\hline xop3 & 41.771 & 56,0 & 60 & $890.800 \ldots 933.043$ \\
\hline xop4 & 22.988 & 55,0 & 40 & $1.090 .593 \ldots 1.113 .981$ \\
\hline xop5 & 17.738 & 52,0 & 36 & $1.164 .000 \ldots 1.182 .911$ \\
\hline xop6 & 41.004 & 57,0 & 59 & $1.271 .454 \ldots 1.312 .958$ \\
\hline xop7 & 38.303 & 45,0 & 63 & $1.387 .512 \ldots 1.426 .215$ \\
\hline xop8 & 40.886 & 56,0 & 72 & $1.996 .525 \ldots 2.037 .811$ \\
\hline xop9 & 43.551 & 57,0 & 66 & $2.081 .681 \ldots 2.125 .632$ \\
\hline xop10 & 32.915 & 51,0 & 65 & $1.703 .061 \ldots 1.736 .376$ \\
\hline ol-r1 & 10,484 & 57,0 & 7 & $1.611 .891 \ldots 1.622 .375$ \\
\hline Xf-AL & Tamanho (bp) & GC\% & ORFs & Coordenadas Genômicas \\
\hline xap1 & 41.622 & 57,0 & 62 & $203.763 \ldots 245.685$ \\
\hline xap2 & 22.978 & 54,0 & 29 & $585.043 \ldots 608.421$ \\
\hline xap3 & 48.027 & 55,0 & 76 & $808.851 \ldots 857.278$ \\
\hline xap4 & 20.150 & 56,0 & 32 & $1.073 .835 \ldots 1.094 .385$ \\
\hline xap5 & 37.661 & 56,0 & 59 & $1.301 .972 \ldots 1.340 .033$ \\
\hline xap6 & 39.002 & 56,0 & 54 & $1.582 .885 \ldots 1.622 .287$ \\
\hline xap7 & 26.309 & 58,0 & 42 & $1.734 .248 \ldots 1.761 .157$ \\
\hline xap8 & 42.407 & 57,0 & 63 & $1.987 .889 \ldots 2.030 .896$ \\
\hline xap9 & 45.251 & 55,0 & 73 & $2.084 .089 \ldots 2.129 .840$ \\
\hline xap10 & 18,200 & 48,0 & 27 & $1.001 .200 \ldots 1.019 .400$ \\
\hline xap11 & 14,923 & 59,0 & 21 & $2.605 .021 \ldots 2.619 .944$ \\
\hline al-r1 & 2,740 & 50,0 & 2 & $1.680 .424 \ldots 1.683 .164$ \\
\hline al-r2 & 10,691 & 54,0 & 14 & $1.909 .860 \ldots 1.920 .551$ \\
\hline al-r3 & 8,536 & 60,0 & 10 & $1.261 .633 \ldots 1.270 .169$ \\
\hline
\end{tabular}

\footnotetext{
* A letra "r" antecedida de um número é abreviação para região remanescente de profago.

$\S$ A ilha genômica de Temecula1 (giPD) encontra-se inserida em xpd2.
} 
Comparando-se com as regiões de profagos já descritas na literatura (Simpson et al., 2000; Van Sluys et al., 2003), em Xf-PD não foi encontrada nenhuma nova região; porém, foram identificadas duas regiões remanescentes. Em Xf-CVC foram identificadas duas novas regiões de profagos, sendo uma região já descrita (xfp6; Canchaya et al., 2003b) e uma nova região não descrita na literatura (xfp5) e mais cinco regiões remanescentes. IGs similares às previamente descritas em Xf-CVC e Xf-PD não foram identificadas em Xf-OL e Xf-AL. As regiões de profagos identificadas em Xf-OL e Xf-AL, assim como as regiões remanescentes identificadas nas quatro linhagens e a região xfp5 de Xf-CVC, constituem resultados inéditos deste trabalho. Cabe ressaltar que os cromossomos das linhagens Xf-OL e Xf-AL usados no presente trabalho ainda são considerados moléculas candidatas devendo ser validadas em algumas ligações (detalhes sobre a montagem das moléculas candidatas no anexo I).

Em termos numéricos, somando-se o tamanho (em pb) de cada região relacionada a profago e de cada região remanescente, encontram-se os valores de: 342.510 pb (12,53\%), 239.751 pb (9,50 \%), 339.583 pb (12,97\%) e 378.497 pb (14,39\%) para Xf-CVC, Xf-PD, XfOL e Xf-AL, respectivamente (em parênteses está o valor proporcional ao tamanho do genoma de cada linhagem). A média nas quatro linhagens é 325.085 pb ou 12,38\% do genoma. Subtraindo-se as regiões de profagos e IGs, as linhagens apresentam respectivamente: 2.389.283 pb, 2.281.416 pb, 2.278.021 pb e 2.251.300 pb, ou média de 2,3 Mb, que pode ser atribuído como tamanho médio do genoma do gênero Xylella (excetuando-se os EGMs).

Com o intuito de avaliar a posição relativa dos genes que codificam as integrases, e por conseqüência dos EGMs associados, no cromossomo bacteriano, esse foi dividido arbitrariamente em três porções de $900 \mathrm{~Kb}$. A figura 4.1 ilustra essa distribuição no genoma das quatro linhagens de Xf. A figura 4.2 ilustra a distribuição das integrases ao longo do genoma das quatro linhagens de Xf em relação aos seus tamanhos (pb) e permite visualizar que, em média, há um distanciamento de pelo menos $205 \mathrm{~kb}$ e $25 \mathrm{~kb}$ da origem de replicação (base 1) respectivamente para integrases completas (regiões de profagos) e fragmentos (regiões remanescentes). Se considerarmos a distribuição relativa entre as ORFs e a sua forma (completa, com FS ou incompleta), verifica-se que há uma tendência de que as proteínas completas, assim como as maiores $(\mathrm{pb})$ regiões de profagos, se acumularem na porção próxima à região de término de replicação. 


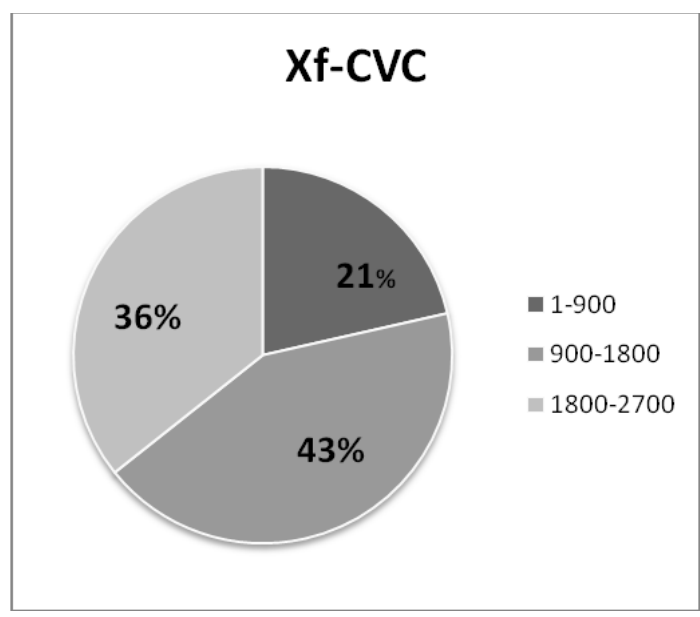

Porção A - 3 Completas.

Porção B - 2 Completas, 1 FS/SCF e 3 Fragmentos.

Porção C - 2 Completas, 1 FS/SCF e 2 Fragmentos.

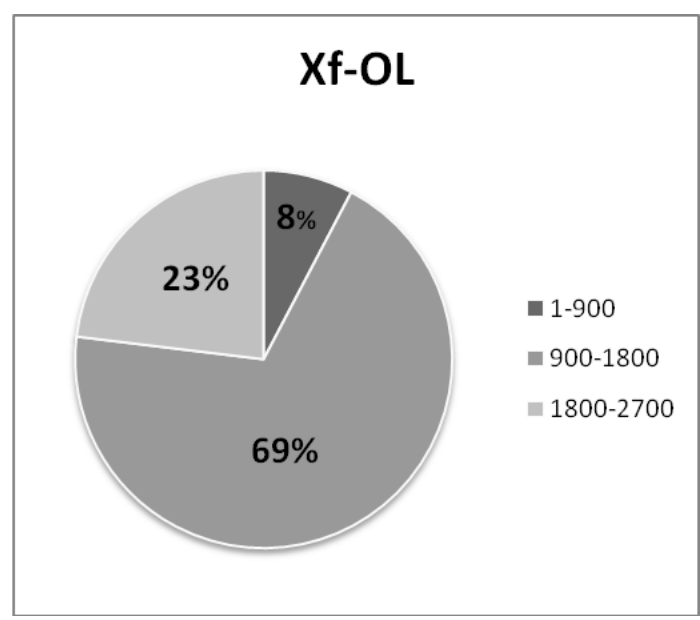

Porção A - 1 Completa

Porção B - 6 Completas, 2 FS/SCF e 1 Fragmento

Porção C - 2 Completas e 1 FS/SCF

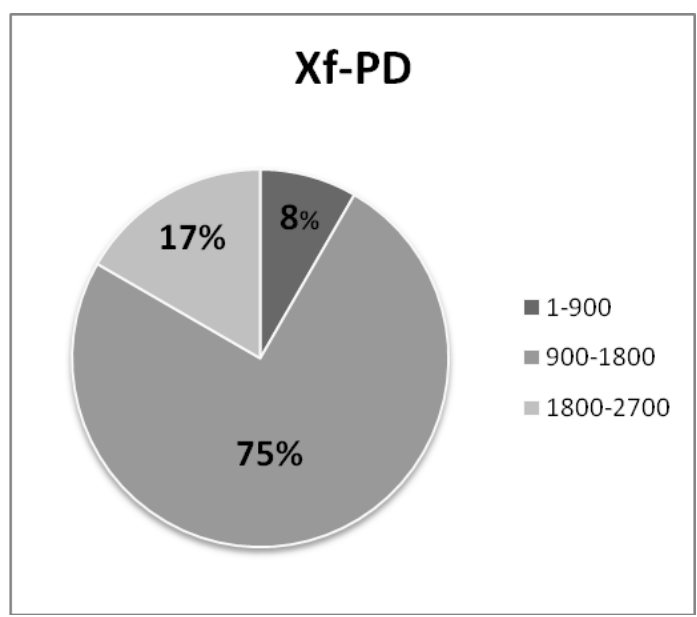

Porção A - 1 Completa.

Porção B - 6 Completas, 1 FS/SCF e 2 Fragmentos.

Porção C -2 FS/SCF.

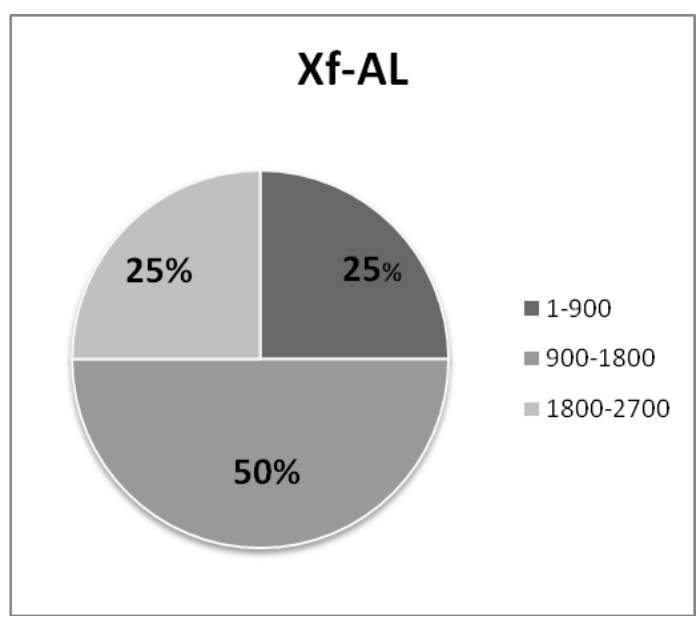

Porção A - 3 Completas e 1 Fragmento

Porção B - 6 Completas e 3 Fragmentos

Porção C - 1 Completa, 2 FS/SCF e 1 Fragmento

Figura 4.1. Distribuição das integrases de fagos (completas, FS/SCF e fragmentos) ao longo dos cromossomos das linhagens de Xf. Legenda: Porção A: base 1 até $900 \mathrm{~Kb}$ (em cinza escuro); Porção B: $900 \mathrm{~Kb}$ até 1,8 $\mathrm{Mb}$ (em cinza); Porção C: 1,8 Mb até 2,7 Mb (fim do genoma) (em cinza claro). 


\section{Xf-CVC}

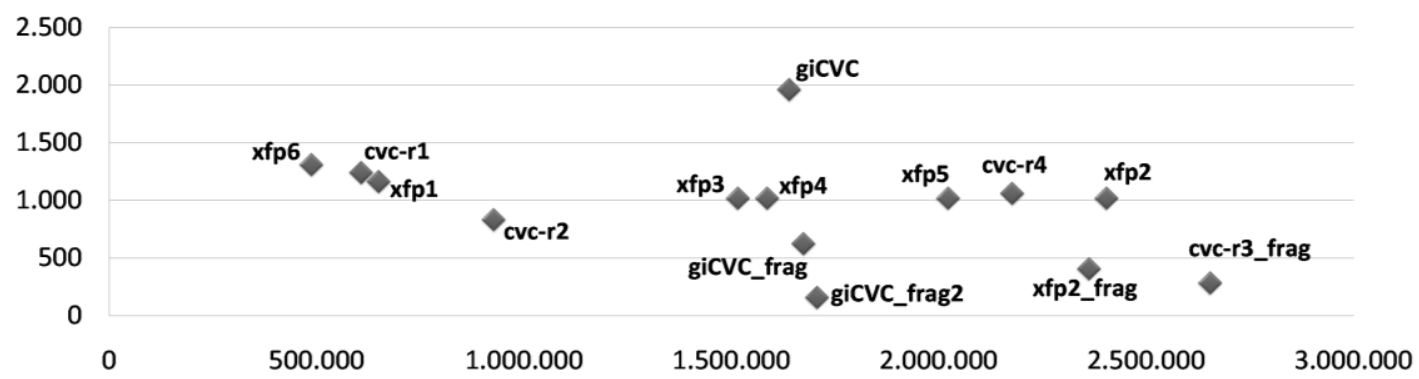

\section{Xf-PD}

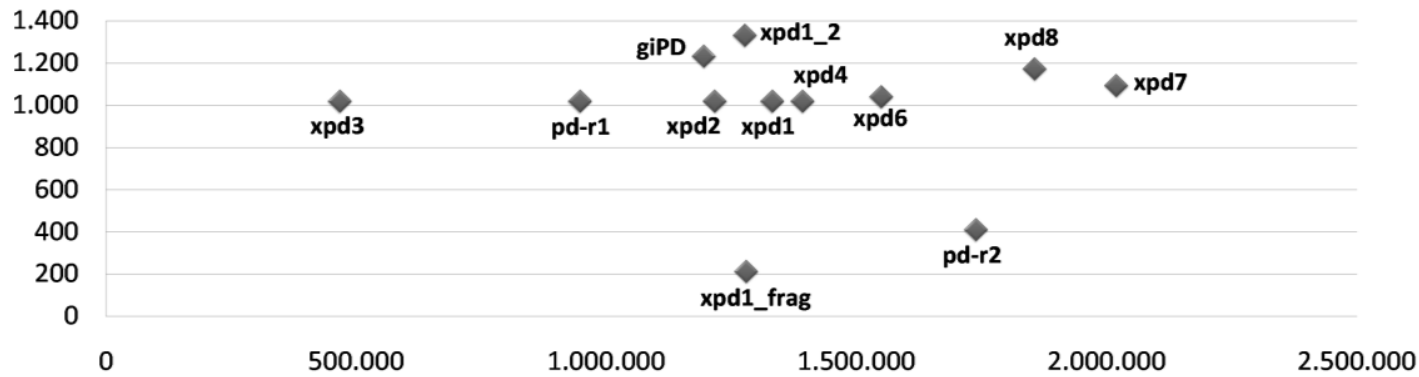

\section{$\mathbf{X f - O L}$}

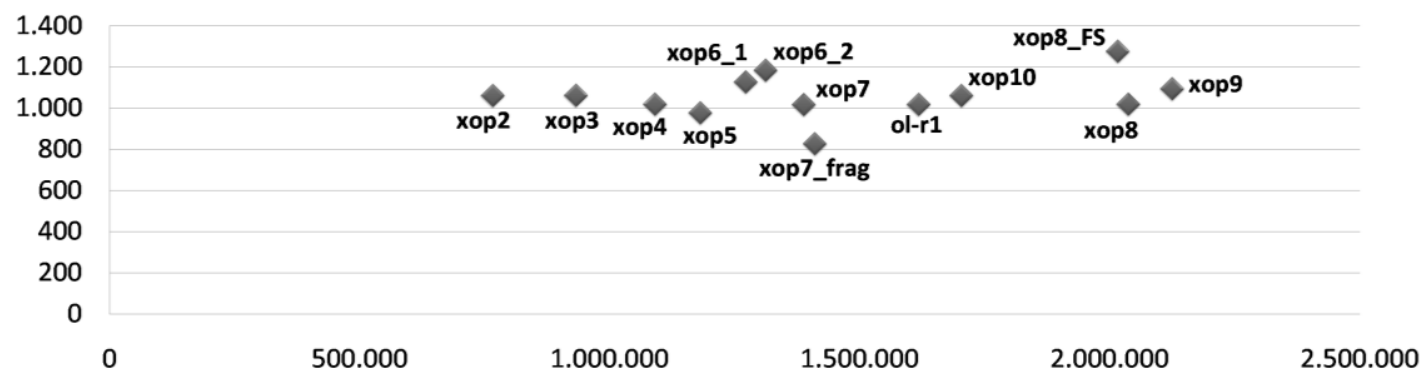

\section{Xf-AL}

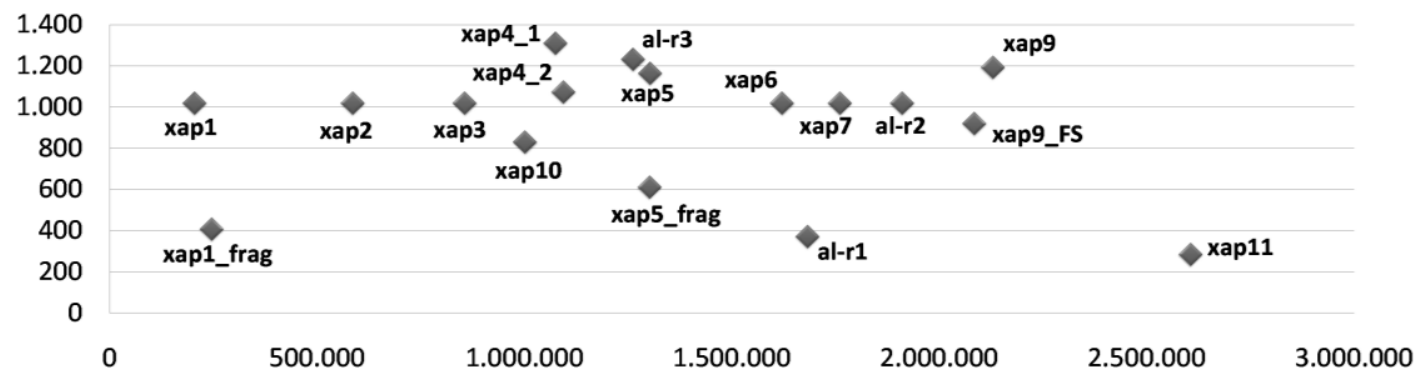

Figura 4.2. Distribuição das integrases de fagos ao longo do cromossomo de cada linhagem de Xf. O eixo X representa o cromossomo a partir da base 1 (dnaA) e o eixo Y representa o tamanho em pb de cada integrase. 
Com relação aos resultados apresentados, a primeira constatação está relacionada ao genoma de Xf-OL que, apesar de apresentar aproximadamente $100 \mathrm{~kb}$ de diferença quando comparado a Xf-PD, se subtraídas as sequiências de fagos e IG, os dois genomas apresentam o mesmo tamanho quase em exatidão (diferença de aproximadamente $3 \mathrm{~kb}$ ), sendo que também apresentam número e distribuição similar de integrases (completas, FS/SCF e fragmentos) ao longo de seus genomas. Essas semelhanças podem sugerir que estas duas linhagens possam estar mais próximas no contexto evolutivo dos quatro genomas em estudo.

A segunda constatação está associada aos resultados encontrados para Xf-AL, que é a linhagem que apresenta a maior quantidade e as maiores regiões de profagos, assim como maior número de integrases, em particular integrases completas (10), com distribuição ao longo de quase toda a molécula candidata. Esta constatação pode sugerir que Xf-AL seja uma linhagem que foi, ou é, mais susceptível à infecção por fagos.

Por último, as linhagens Xf-CVC e Xf-AL apresentam a maior quantidade de fragmentos de integrases (5 para cada linhagem), enquanto que Xf-PD e Xf-OL apresentam maior quantidade de integrases em FS/SCF (3 para cada linhagem), sendo que ao menos uma região relacionada a profagos em cada linhagem não apresenta integrase. A princípio isso pode significar que as regiões correspondentes poderiam estar "estáveis" no genoma, ou seja, incapazes de se mobilizarem, sugerindo que: (a) as regiões poderiam estar em processo de decaimento genômico; ou (b) as regiões poderiam ser importantes ou trazer alguma vantagem para a bactéria, que as manteve integradas e "estáveis" no genoma. Ambas hipóteses sugerem um papel importante das integrases e regiões associadas com a evolução e diversificação das linhagens de Xf. 


\subsection{CLASSIFICAÇÃO E RELAÇÕES ENTRE AS INTEGRASES: ANÁLISE DO DOMÍNIO CATALÍTICO}

Para a classificação, foi realizado alinhamento completo das seqüências de aminoácidos de 48 integrases de Xf pelo programa CLUSTALX (as integrases menores que 140 resíduos de aminoácidos foram excluídas desta análise), sendo que o alinhamento completo pode ser visualizado no anexo II. De modo a realizar uma primeira avaliação da eventual relação destas regiões de profagos das quatro linhagens de Xylella com bacteriófagos bem caracterizados na literatura, incluíram-se neste alinhamento as seqüências das integrases-modelo propostas por Groth e Calos (2004): R4 do fago de Streptomyces parvulus e phiC31 do fago de Streptomyces lividans (para as serinas recombinases); e HK022 e Lambda do fago de Escherichia coli e L5 do fago de Mycobacterium smegmatis (para as tirosinas recombinases). Posteriormente, estes alinhamentos passaram por uma edição manual (uso do programa GENEDOC), com exclusão das regiões contendo GAPs, para geração de uma árvore de distância não enraizada pelo método de Neighbor Joining (NJ) (Figura 4.3).

A figura 4.3 apresenta a árvore de distância resultante e pode-se notar claramente a existência de 5 ramos (identificados pelas letras A-E). As integrases do ramo $\mathbf{A}, \mathbf{B}$ e $\mathbf{C}$ estão relacionadas com tirosinas recombinases provenientes dos fagos Lambda e HK022; as integrases do ramo $\mathbf{D}$ estão relacionadas com a tirosina recombinase proveniente do fago L5; e apenas as integrases do ramo $\mathbf{E}$ estão relacionadas às serinas recombinases. Cabe ressaltar que as integrases de ilhas genômicas estão presentes em dois ramos distintos: ramos $\mathbf{C}$ (giPD) e D (giCVC). Estes resultados sugerem que as regiões de profagos contendo as integrases possam ter sido originadas a partir de ao menos três ancestrais comuns, pertencentes à família dos fagos do tipo lambda (ramos A, B e C), L5 (ramo D) e phiC31 (ramo E).

Com o objetivo de refinar as relações de agrupamento, o alinhamento gerado anteriormente foi submetido ao método network adaptado de Holden e colaboradores (2007), onde as inter-relações entre as integrases foram computadas por BLASTP e matriz de distância JTT (Figura 4.4). Com esta metodologia, visualiza-se a rede de relações possíveis entre as integrases em termos de seqüência de aminoácidos, acrescentando informação de similaridade e distância, sendo um método de agrupamento alternativo à abordagem de NJ. 


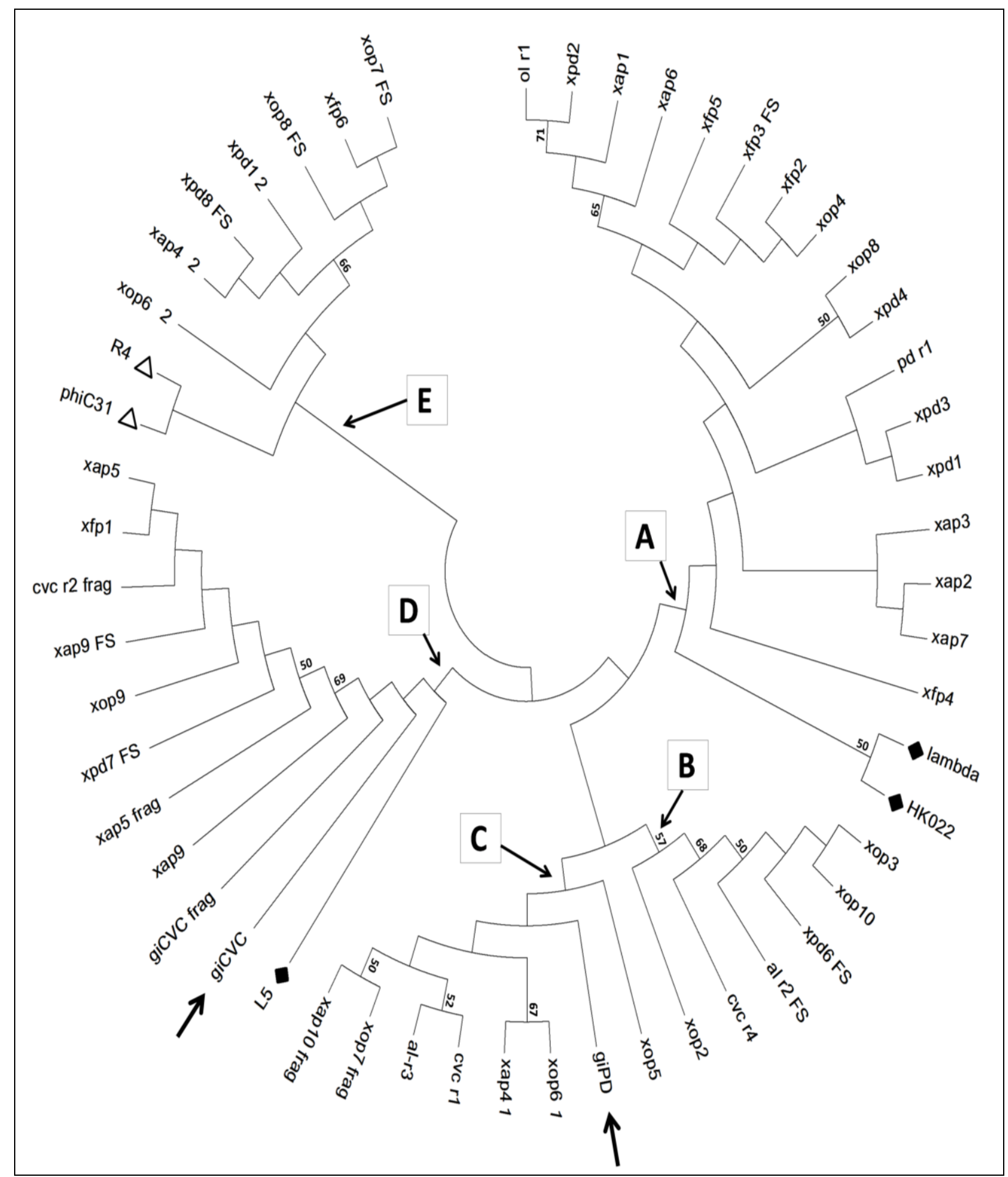

Figura 4.3 Classificação das integrases, computadas através de árvore de distância (método de neighbor-joining, com bootstrap de 1.000 réplicas). Serinas recombinases modelo: triângulos brancos (R4: integrase do fago de Streptomyces parvulus; phiC31: integrase do fago de Streptomyces lividans); Tirosinas recombinases modelo: losangos em preto (lambda: integrase do fago lambda; HK022: integrase do fago de Escherichia coli; e L5: integrase do fago de Mycobacterium smegmatis). Integrases de IGs estão indicadas pelas setas negras. Ao todo 48 integrases de Xf estão divididas em cinco ramos principais, indicados pelas letras (Fragmentos menores que 140 resíduos de aminoácidos não foram incluídos nesta árvore, vide tabela 4.1). 


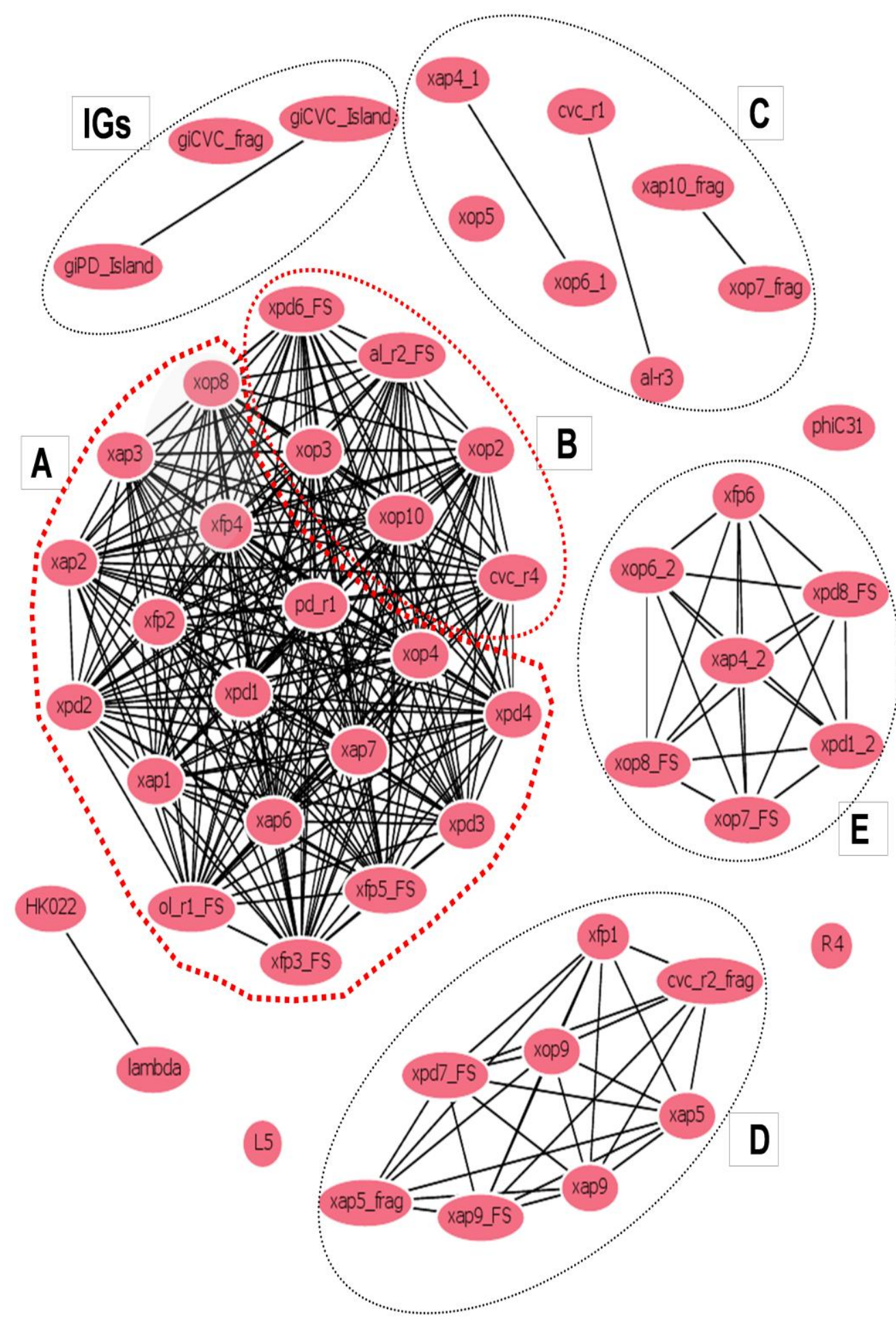

Figura 4.4. Análise de agrupamento pelo método Network das integrases previamente apresentadas na figura $\mathbf{4 . 3}$ (incluindo Serinas e Tirosinas recombinases modelos). As linhas pretas indicam a existência de interrelação entre as integrases por BLASTP, sendo as distâncias computadas por matriz Jones Taylor Thornton (JTT). Os ramos de integrases previamente identificados na figura 4.3 estão identificados nos círculos pontilhados em preto, junto às caixas de texto indicando o ramo ao qual pertencem. $\mathrm{O}$ grupo $\mathbf{A}$ e B estão destacados em círculos pontilhados na cor vermelha. 
A análise dos resultados obtidos por network (Figura 4.4) também sugere a existência de 5 agrupamentos. No entanto, as relações entre as proteínas são um pouco distintas. Todas as proteínas contidas no ramo $\mathbf{A}$ se mantém relacionadas, porém o ramo $\mathbf{B}$ é incorporado à mesma rede de relações. As integrases do ramo $\mathbf{C}$ apresentam poucas inter-relações, sendo que a integrase xop5 não apresenta nenhuma inter-relação, sugerindo tratar-se de uma integrase diferenciada das demais em termos de seqüência de aminoácidos (Anexo II). As integrases associadas às ilhas genômicas encontram-se separadas do restante. Os ramos $\mathbf{D}$ e $\mathbf{E}$ também são consistentes considerando-se as duas abordagens de agrupamento. É importante notar que a análise de network também evidencia que nenhuma integrase-modelo apresenta inter-relação com as integrases de Xf.

Portanto, de uma forma geral, as abordagens utilizadas corroboram a classificação de cinco ramos de integrases, onde $41(86 \%)$ integrases estão relacionadas a tirosinas recombinases (ramos A, B, C e D) e 7 (14\%) integrases estão relacionadas a serinas recombinases modelos (ramo E), sendo necessária uma análise mais acurada dos domínios catalíticos para confirmar esta hipótese. Esta análise está descrita a seguir.

\subsubsection{Análise do Domínio Catalítico: Famílias Serina ou Tirosina Recombinases}

Domínios protéicos são regiões presentes nas proteínas relacionadas com sua estrutura tridimensional, função e/ou evolução (George et al., 2004). Com base nessa proposta, cada ramo apresentado na figura 4.3 foi estudado individualmente, assim como as integrases de IGs, a fim de identificar o domínio catalítico (conforme o modelo proposto por Groth e Calos, 2004). De modo geral, as tirosinas recombinases apresentam assinatura em sua porção carboxila terminal com os seguintes resíduos: R[212], K[225], H[308], R[311], H[333] e Y[342]; e as serinas recombinases apresentam assinatura catalítica em sua porção amino-terminal, com o resíduo $\mathrm{S}[12]$ e presença de vários resíduos de cisteína.

Nesse trabalho, a identificação dos domínios em cada integrase de Xf foi realizada com base em buscas nos bancos de domínios conservados CDD (Conserved Domain Database), InterPRO (Database of Protein Families) e o banco de estruturas PDB (Protein Data Bank). Estas análises estão descritas a seguir, e apresentadas em detalhes no Anexo III. 


\section{A. Integrases de fagos associadas a tirosinas recombinases (Ramos A, B, C e D)}

As integrases de Xf associadas aos modelos com domínio tirosina recombinase estão representadas em quatro ramos, conforme apresentado na figura 4.3. O primeiro ramo (Ramo A) é formado por 17 integrases (5 de Xf-PD e Xf-AL, 4 de Xf-CVC e 3 de Xf-OL), sendo 14 completas e 3 em FS/SCF. As integrases deste grupo apresentam como principal domínio conservado CDD INT_lambda_C; este domínio representa a porção carboxila terminal da proteína, responsável pela atividade catalítica desta integrase, e está presente em bacteriófagos temperados, em particular no bacteriófago lambda. Apresentam também o domínio CDD INT_P4, abrangendo as regiões N- e C-terminais; este domínio, característico do fago P4, também é encontrado em fagos temperados, plasmídeos integrativos, ilhas genômicas e outros elementos genéticos móveis (Anexo III e Figura 4.5B). Todas as integrases pertencentes a este ramo foram classificadas como tirosinas recombinases; apesar de não apresentarem o resíduo H (histidina) esperado na posição 308, apresentam os demais resíduos que caracterizam o domínio tirosina recombinase em suas posições esperadas (Figura 4.5A).

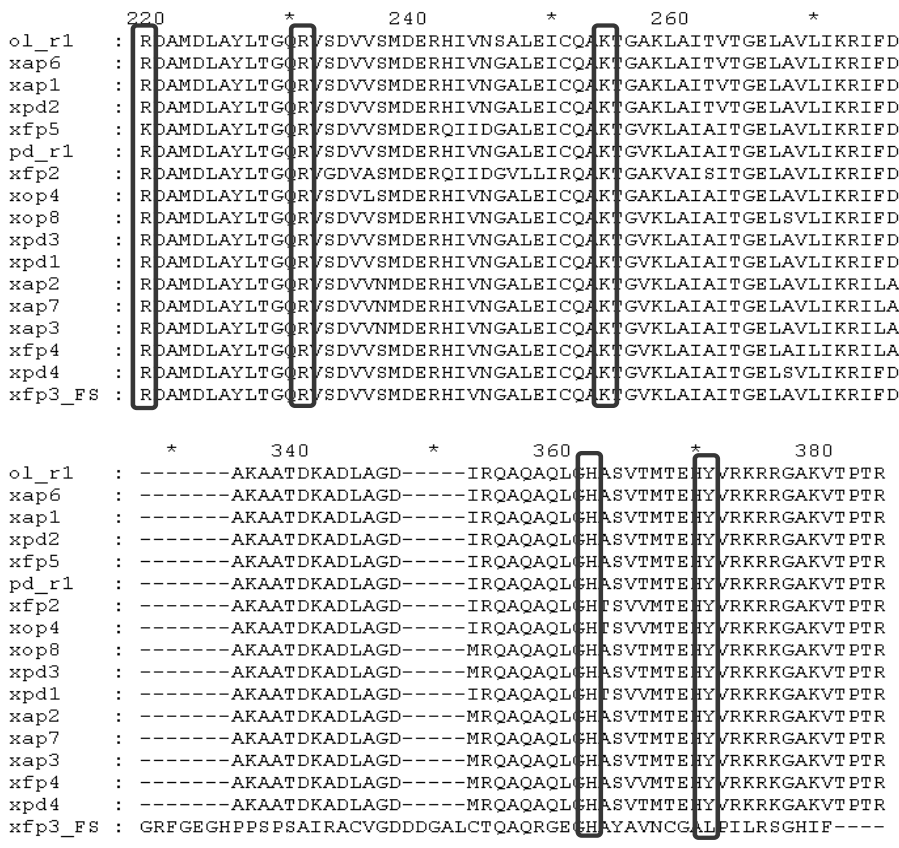

$280-300$

$300 \quad * \quad 320$

\begin{tabular}{|c|c|c|c|c|}
\hline & & & HVNS: & \\
\hline & & & & \\
\hline ap1 & & MDLAYLTG $R$ & VSMDERHIVNGALEICQA & GAKLAITVTGE LAVLIKRI \\
\hline$d 2$ & & AMDLAYLTG $\mathrm{R}$ & ISDVVSMDE RHIVNGALEICQA & GAKLAITVTGELAVLIKR \\
\hline & & DAMDLAYLTG & SDVVSMDERQIIDGALEICQA & GVKLAIAITGELAVLIKR \\
\hline$r 1$ & & PAMDLAYLTG R & SDVVSMDERHIVNGALEICQA & GVKLAIAITGELAVLIKRJ \\
\hline 2 & & PAMDLAYLTG $R$ & GDVASMDERQIIDGVLLIRQA & GAKVAI SITGE LAVLI KR \\
\hline 4 & : & RAMDLAYLTG $\$ R$ & SSDL SMDERHIVNGALEICQA & GAKLAIAITGE LAVLIKRI \\
\hline & & PAMDLAYLTG $\$ R$ & SDVVSMDERHIVNGALEICQA & GVKLAIAITGELSVLIKRI \\
\hline & & DAMDLAYLTG RR & SDVVSMDERHIVNGALEICQA & GVKLAIAITG \\
\hline & : & AMDLAYLTG R & SSDVSMDERHIVNGALEICQA & GVKLAIAITGELAVLIKR] \\
\hline & & AMI & & $t^{2}$ \\
\hline & & & RHIVNGALEICQ! & GVK \\
\hline & : & a) & ISDVVNMDERHIVNGALEICQA & GVKLAIAI \\
\hline & & & & \\
\hline & & DAML & $\mathrm{SD}$ & GVK \\
\hline & & & & \\
\hline & & 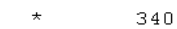 & * & \\
\hline & & & & \\
\hline & & - A.KA.A. & -IRQAQAQL & VTMTE HY /RKRRGAI \\
\hline & & - A.KA.T.T D & AGD-----IRQAQAQLL & SVTMTE HY /RKRRGAI \\
\hline & & $--A_{1}$ & AQAQL & SVTMTEHY/VRKRF \\
\hline & & ---- AKAATD & KADLAGD-----IRQAQAQL & SVTMTE HY/RKRRGAK \\
\hline & & - -AKAATD & KADLAGD-----IRQAQAQL & ASVTMTE HY /RKRRGAI \\
\hline & & $--A . K$ & KADLAGD-----IRQAQAQL & SVVMTE HY /RKRF \\
\hline & & --AKAATD & KADLAGD-----IRQAQAQL & FVVMTE FY /RKRKGAKVT P \\
\hline & & - AKAATD & KADLAGD-----MRQAQAQL & ASVTMTEFY/VRKRF \\
\hline & & ---- AKA.TA & KADLAGD-----MRQAQAQL & SVTMTE EY /RKR \\
\hline & & -- A. & $-I$ & SVMMTE: \\
\hline & & ---- A.KA.ATD & KADLAGD----MRQA.QAQL & SVTMTE IY /RKRRGA \\
\hline & & ---- AKA.ATD & KADLAGD----MRQAQAQL & SVTMTE IY /RRRRG \\
\hline & & 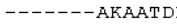 & $\mathrm{K}$ & SVTMTE: \\
\hline & & ---- AKAATD & KADLAGD-----MRQA & SVVMTE EY /RKRKGAKVT \\
\hline & & ---- AKAATD & KADLAGD-----MRQAC & KRKGAKVT \\
\hline & & & & \\
\hline
\end{tabular}

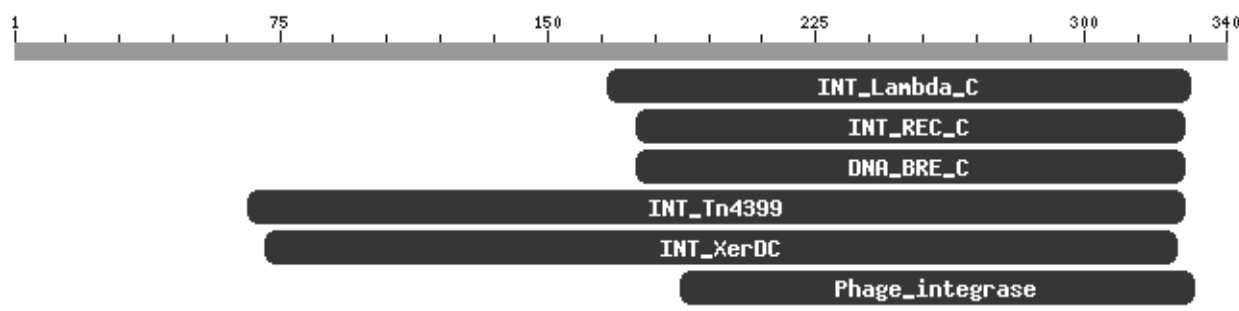

Figura 4.5. A, Alinhamento da porção C-terminal das integrases classificadas no ramo A. Nos blocos em destaque, os sítios catalíticos conservados com outras proteínas da família das tirosinas recombinases. B, Resultados de busca de domínios no banco CDD. Para lista completa dos domínios CDD e InterPro em todas integrases, ver Anexo III (A-D). 
Os ramos B e C são formados por 13 integrases ( 2 de Xf-CVC, 1 de Xf-PD, 6 de Xf-OL e 4 de Xf-AL), sendo 9 completas, 2 em FS/SCF e 2 fragmentos. As integrases do ramo $\mathbf{B}$ apresentam como domínios conservados CDD INT_lambda_C e INT_P4 e, assim como observado pela figura 4.3, estão próximas as integrases do ramo $\mathbf{A}$, porém apresentam pequenas diferenças de alinhamento (Anexo II), sendo também classificadas como tirosinas recombinases (Anexo III e Figura 4.6). As integrases do ramo B não apresentam o resíduo $\mathrm{H}$ esperado na posição 308, porém apresentam todos demais resíduos que caracterizam as tirosinas recombinases (Figura 4.6). As integrases xpd6 e al-r2, apesar de apresentarem FS/SCF, possuem todos os resíduos que caracterizam o domínio catalítico, sendo aparentemente funcionais.

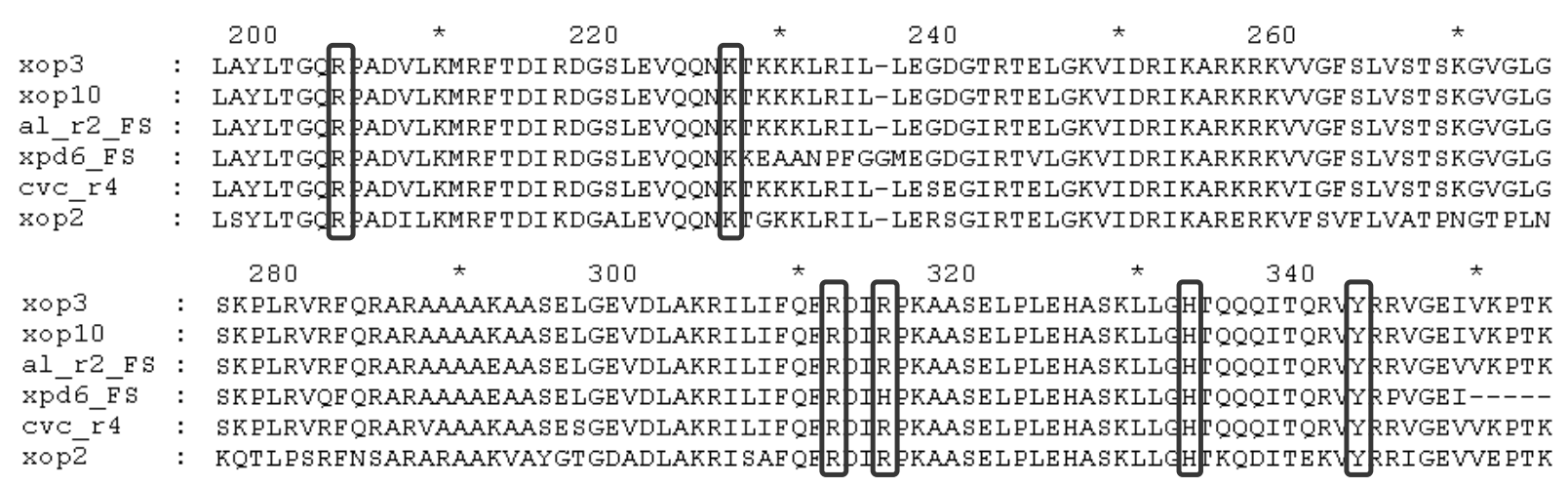

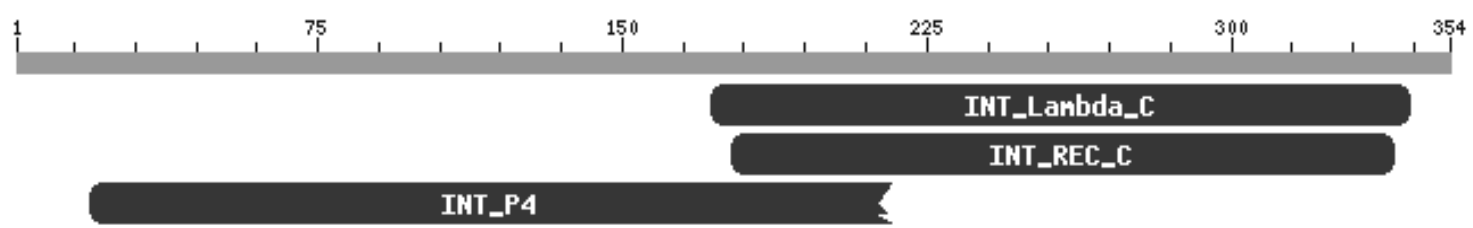

Figura 4.6. A, Alinhamento da porção C-terminal das integrases classificadas no ramo B. Nos blocos em destaque, os sítios catalíticos conservados com outras proteínas da família das tirosinas recombinases. B, Resultados de busca de domínios no banco CDD. Para lista completa dos domínios CDD e InterPro em todas integrases, ver Anexo III (A-D).

Dentre as integrases da subdivisão C, xop6_1, xap4_1, al-r3 e cvc-r1 apresentam todos os domínios catalíticos para as tirosinas recombinases; no entanto, a baixa similaridade das seqüências neste ramo, conforme foi apontada pela análise de network, produziu um alinhamento de baixa qualidade, e alguns dos resíduos, apesar de presentes, podem estar erroneamente identificados no alinhamento produzido (Figura 4.7). As principais diferenças entre o ramo $\mathbf{C}$ com A e B está relacionado com o alinhamento da porção amino-terminal, conforme pode ser observado no anexo II. Os principais domínios CDD identificados em C são INT_P4 para as 
integrases al-r3 e cvc-r1, domínio INT_Rci/Cre para as integrases xop6_1 e xap4_1 (domínio encontrado na recombinase do plasmídeo R64, relacionada a inversões cromossômicas) e domínio INT-P22-C para xop7 e xap10_frag (domínio presente nos bacteriófago APSE-1 e DLP12, responsáveis por infectar Acyrthosiphon pisum e Escherichia coli, respectivamente) (Anexo III e Figura 4.7).

A

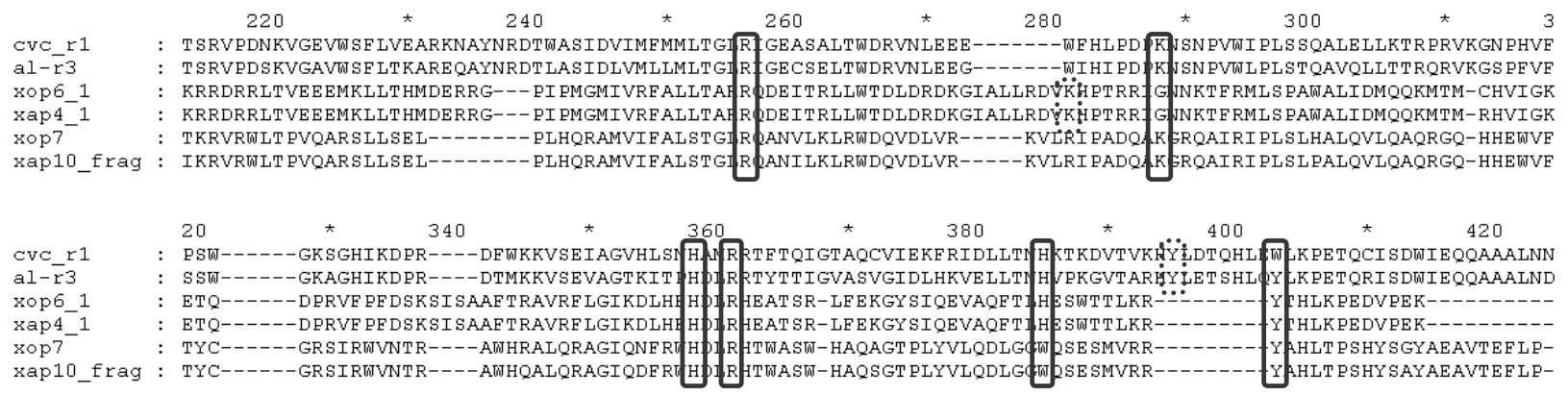

B

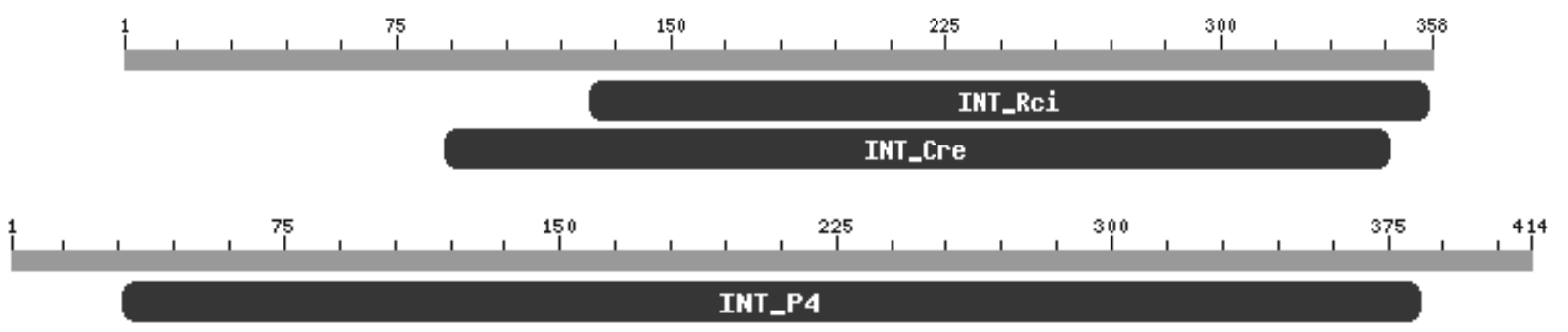

Figura 4.7. A, Alinhamento da porção C-terminal das integrases classificadas no ramo C. Nos blocos em destaque, os sítios catalíticos conservados com outras proteínas da família das tirosinas recombinases. Blocos pontilhados indicam potenciais resíduos alinhados erroneamente. B, Resultados de busca de domínios no banco CDD. Para lista completa dos domínios CDD e InterPro em todas integrases, ver Anexo III (A-D).

O ramo $\mathbf{D}$ é formado por 8 integrases $(2$ de Xf-CVC, 1 de Xf-PD, 1 de Xf-OL e 4 de Xf-AL), sendo 4 completas, 2 em FS/SCF e 2 fragmentos. Com exceção dos fragmentos, todas foram classificadas como tirosinas recombinases. Apresentam como principal domínio conservado CDD INT_XerDC, presente nas integrases/recombinases da família XerC e XerD. Essas últimas estão associadas ao evento de resolução das fitas de DNA ao final da replicação de um cromossomo bacteriano circular. Por outro lado, diversas integrases relacionadas à integração e excisão sítio específica de bacteriófagos lisogênicos, mobilização de transposons conjugativos e manutenção de plasmídeos estáveis também apresentam o mesmo motivo (Anexo III e Figura $4.8)$. 


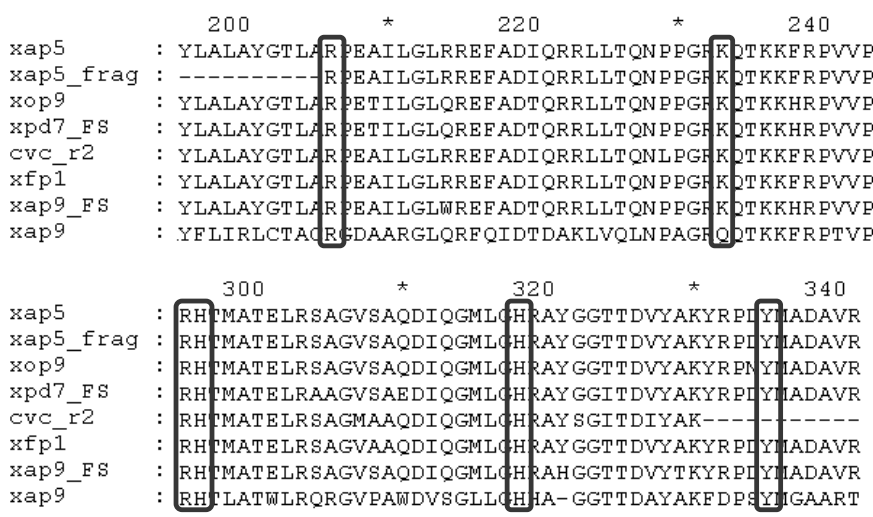

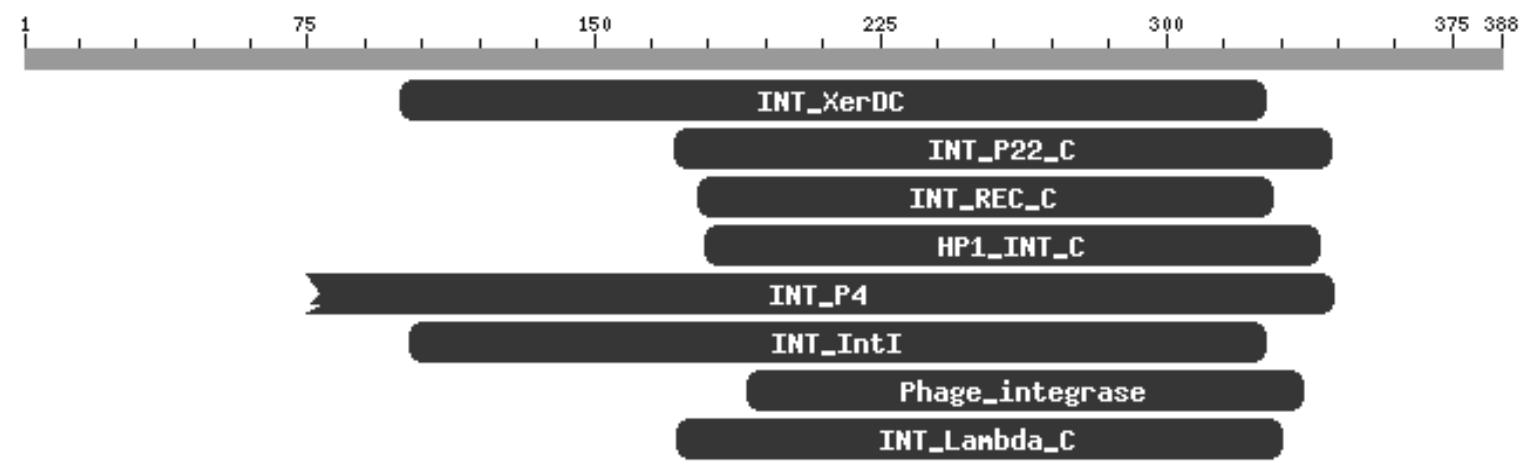

Figura 4.8. A, Alinhamento da porção C-terminal das integrases classificadas no ramo D. Nos blocos em destaque, os sítios catalíticos conservados com outras proteínas da família das tirosinas recombinases. B, Resultados de busca de domínios no banco CDD. Para lista completa dos domínios CDD e InterPro em todas integrases, ver Anexo III (A-D).

\section{B. Integrases de fagos associadas a serinas recombinases (Ramo E)}

O ramo E, agrupado na figura $4.3 \mathrm{com}$ as serinas recombinases modelo, é formado por 7 integrases ( 1 de Xf-CVC, 2 de Xf-PD, 3 de Xf-OL e 1 de Xf-AL), sendo 4 completas e 3 em FS/SCF. Não apresentam domínios CDD característicos de integrases tirosinas recombinases (como INT_lambda ou INT_P22) identificados anteriormente nos outros ramos; apresentam o domínio geral CDD, INT_BRE_C, relacionado com enzimas de quebra e re-ligação do DNA, dos quais as tirosinas recombinases fazem parte. A comparação com os domínios CDD característicos de serinas recombinases modelos (phiC31 e R4) revela que as integrases pertencentes a esse ramo não apresentam nenhum domínio em comum com as serinas recombinases, sugerindo que as integrases deste ramo não poderiam ser enquadradas nessa família (Anexo III e figura 4.9). Além disso, também apresentam todos resíduos catalíticos característicos de tirosinas recombinases (Figura 4.10). Portanto, apesar de agrupadas às serinas 
recombinases, as integrases do ramo $\mathbf{E}$ apresentam todos os indícios de pertencer à família das tirosinas recombinases.

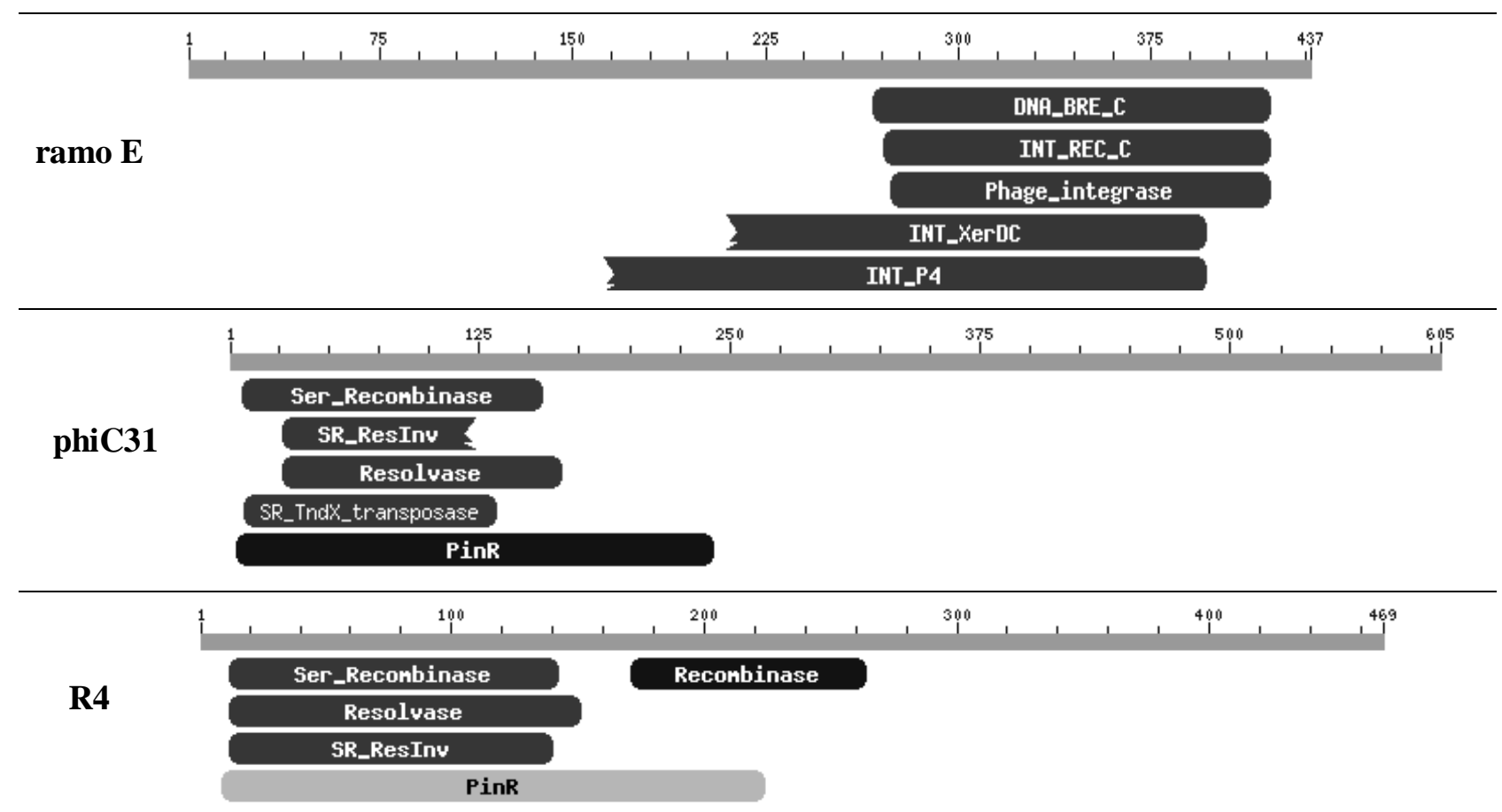

Figura 4.9. Resultado de busca de domínios no banco CDD para integrases do ramo E, bem como para duas serinas recombinases modelos (phiC31 e R4). As integrases do ramo $\mathbf{E}$ não apresentam domínio CDD pertencente às serinas recombinases. Para lista completa dos domínios CDD e InterPRO em todas integrases, ver Anexo III (A-D).

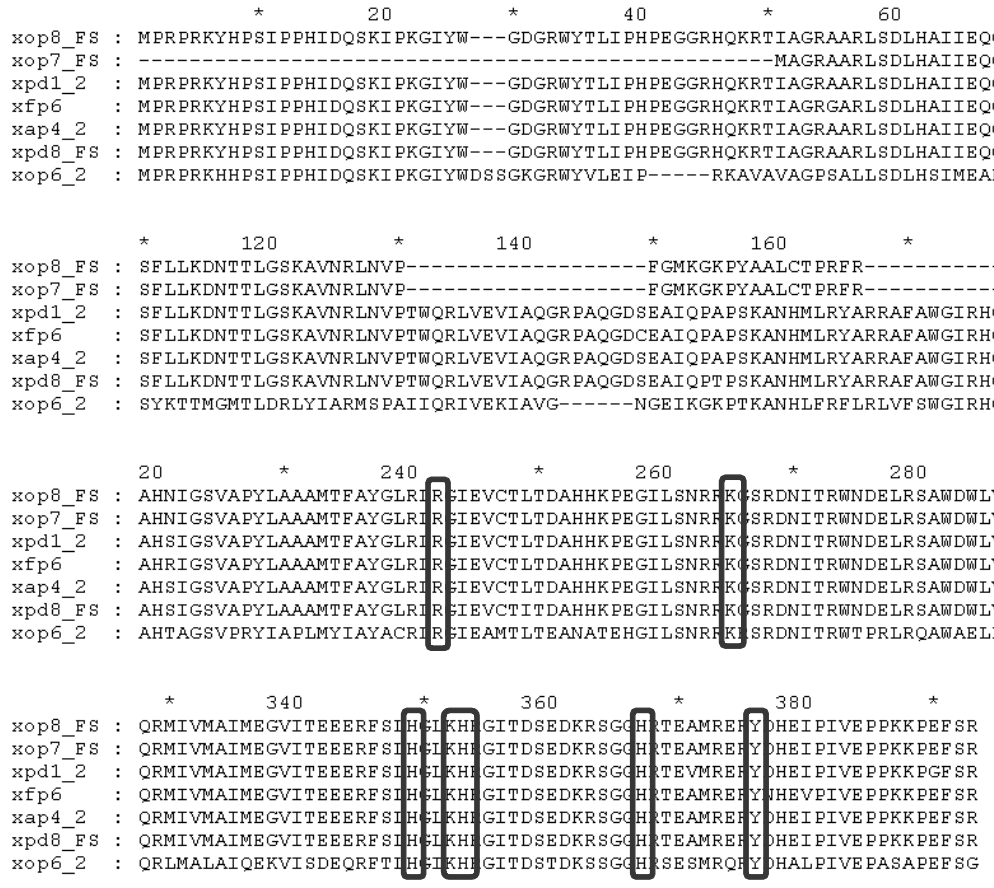

Figura 4.10. Alinhamento das integrases classificadas no ramo E. Nos blocos em destaque, os sítios catalíticos conservados com outras proteínas da família das tirosinas recombinases. 


\section{Integrases de Ilhas Genômicas (IGs)}

As integrases presentes em IGs apresentam o domínio catalítico tirosina recombinase, porém não apresentam a mesma assinatura catalítica e similaridade de resíduos de aminoácidos com as demais integrases encontradas nas regiões de profagos . Estas integrases apresentam domínio conservado CDD INT-P4, também encontrado nas integrases pertencentes aos outros ramos, e o domínio INT_CP4 (PRK09692), encontrado em integrases de profagos presentes no genoma de enterobactérias, em particular em E. coli (Figura 4.11 e Anexo III).

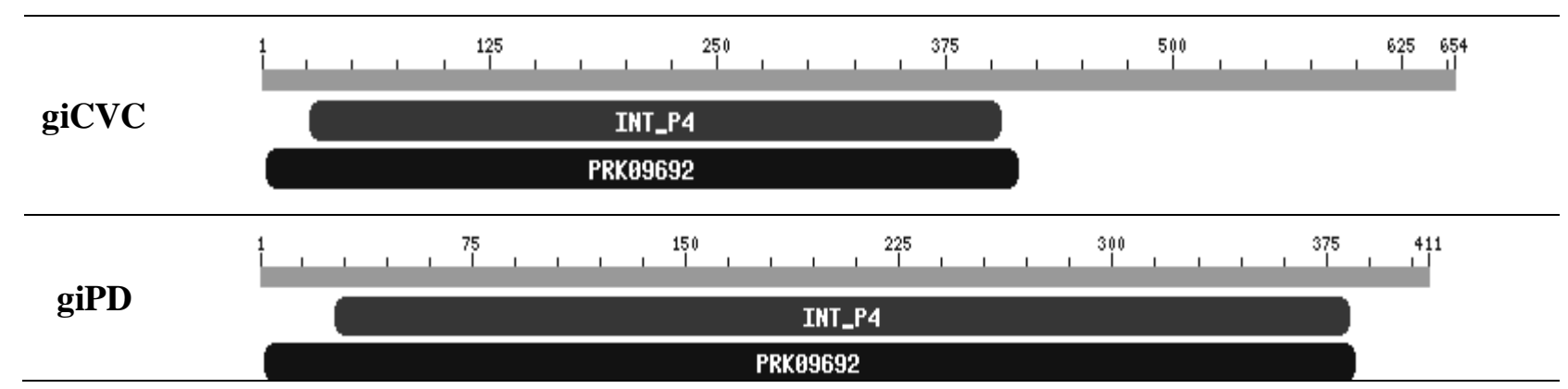

Figura 4.11. Resultado de busca de domínios no banco CDD para integrases giCVC e giPD (vide também Anexo III).

\subsubsection{Domínios Catalíticos Associados ao PDB (Protein Data Bank)}

Várias estruturas tridimensionais, depositadas no banco de dados PDB (Protein Data Bank) estão associadas a recombinases e integrases. Uma busca de similaridade, via BLASTP, com as integrases de Xf contra o banco PDB revelou que estas estão associadas a quatro diferente estruturas, sendo duas integrases de bacteriófagos e duas recombinases bacterianas (Tabela 4.3). A tabela 4.4 aponta os domínios PDB identificados para cada integrase de Xf, indicando que 23 (40\%) integrases (11 completas, 3 FS/SCF e 9 fragmentos) não apresentam PDB relacionado; outras 23 (40\%) (20 completas e 3 FS/SCF) apresentam PDB relacionado com a estrutura do fago lambda, 9 (16\%) integrases (4 completas, 2 FS/SCF e 3 fragmentos) apresentam PDB relacionado à integrase do fago HP1 e 2 (4\%) integrases $(1$ completa e 1 fragmento) apresentam PDB associado a recombinases sítio específicas.

Os resultados mostram que as integrases dos ramos $\mathbf{C}, \mathbf{E}$ e giPD não estão associadas a estruturas PDB, enquanto integrases dos ramos A e $\mathbf{B}$ estão associadas à estrutura da integrase do fago lambda que infecta $E$. coli, e as integrases do ramo $\mathbf{D}$ estão associadas com a integrase do fago HP1 que infecta Haemophilus influenzae (pertencente à família dos fagos da família P2). A 
integrase giCVC está associada à estrutura de recombinases sítio-específicas em geral. Portanto, a análise das estruturas PDB sugere que ao menos duas famílias de fagos estão presentes na história evolutiva de Xf. A primeira família é a Siphoviridae (fago lambda), relacionada a fagos que não apresentam longa cauda retrátil (long non-contractile tails), sendo esta família formada por 9 subfamílias (C2, L5, Lambda, N15, phiC31, psiM1, T1, T5 e os não classificados). A segunda família é a Myoviridae (fago HP1), relacionada a fagos que apresentam cauda retrátil (contractile tails); esta família é formada por 7 subfamílias $(\mathrm{Mu}, \mathrm{P} 1, \mathrm{P} 2$, phiH, SPO1, T4 e os não classificados).

Tabela 4.3. Estruturas PDB relacionadas a integrases e recombinases de fagos e bactérias

\begin{tabular}{l|l|l}
\hline Entrada PDB & Descrição & Organismo \\
\hline $1 \mathrm{~A} 0 \mathrm{P}$ & Recombinase sítio-específica XerD & Escherichia coli \\
\hline $1 \mathrm{AIH}$ & Hp1 integrase, sítio catalítico & Bacteriófago Hp1 \\
\hline $1 \mathrm{AE} 9$ & Integrase Lambda, sítio catalítico & Bacteriófago lambda \\
\hline 1P7D & Integrase Lambda ligada ao DNA & Bacteriófago lambda \\
\hline 1Z19/1Z1B & Integrase Lambda, dímero ligado ao sítio & Bacteriófago lambda \\
\hline $1 \mathrm{Z1G}$ & Integrase Lambda, tetrâmero ligado a junção Holliday & Bacteriófago lambda \\
\hline $2 \mathrm{~A} 3 \mathrm{~V}$ & Recombinase sítio-específica IntI4 & Vibrio cholerae \\
\hline
\end{tabular}

Tabela 4.4. Estruturas PDB associadas às integrases de Xylella fastidiosa

\begin{tabular}{|c|c|c|}
\hline \multirow{4}{*}{ Integrases sem PDB relacionado } & $\mathrm{Xf}-A L$ & al_r1_frag, al-r3, xap4_1, xap4_2, xap11_frag \\
\hline & $\mathrm{Xf}-C V C$ & $\begin{array}{l}\text { cvc_r1, cvc_r2_frag, cvc_r3, giCVC_frag, giCVC_frag2, } \\
\text { xfp2_frag, xfp6 }\end{array}$ \\
\hline & $\mathrm{Xf}-\mathrm{Ol}$ & xop5, xop6_2, xop6_1, xop7_frag, xop7_FS, xop8_FS \\
\hline & $\mathrm{Xf}-P D$ & pd_r2_frag, giPD, xpd1_2, xpd1_frag, xpd8_FS \\
\hline \multirow{4}{*}{$\begin{array}{l}\text { Integrases relacionadas à integrase } \\
\text { lambda, associadas ou não com } \\
\text { recombinases sítio-específicas }\end{array}$} & $\mathrm{Xf}-A L$ & al_r2_FS, xap1, xap2, xap3, xap6, xap7 \\
\hline & $\mathrm{Xf}-C V C$ & cvc_r4, xfp2, xfp3_FS, xfp4, xfp5 \\
\hline & $\mathrm{Xf}-\mathrm{Ol}$ & ol_r1, xop2, xop3, xop4, xop8, xop10 \\
\hline & $\mathrm{Xf}-P D$ & pd_r1, xpd1, xpd2, xpd3, xpd4, xpd6_FS \\
\hline \multirow{4}{*}{$\begin{array}{l}\text { Integrases relacionadas à integrase } \\
\text { HP1, associadas ou não com } \\
\text { recombinases sítio-específicas }\end{array}$} & $\mathrm{Xf}-A L$ & xap5, xap5_frag, xap9, xap9_FS, xap10_frag \\
\hline & $\mathrm{Xf}-C V C$ & $\mathrm{xfp} 1$ \\
\hline & $\mathrm{Xf}-\mathrm{Ol}$ & xop7_frag, xop9 \\
\hline & $\mathrm{Xf}-P D$ & xpd7_FS \\
\hline \multirow{2}{*}{$\begin{array}{c}\text { Apenas PDB de recombinases sítio- } \\
\text { específicas }\end{array}$} & $\mathrm{Xf}-A L$ & xap1_frag \\
\hline & $\mathrm{Xf}-C V C$ & giCVC \\
\hline
\end{tabular}




\subsection{ASSOCIAÇÃO DAS INTEGRASES DE Xf COM BACTERIÓFAGOS}

Conjuntos de genes conservados que apresentam similaridade de seqüência são características proeminentes em cromossomos bacterianos (Overbeek et al., 1999). As linhagens de Xf apresentam conjuntos de integrases relacionadas a profagos e ilhas genômicas, e associados com rearranjos genômicos e aquisição de elementos genéticos móveis, estando relacionadas diretamente ao mecanismo de diferenciação destas linhagens (Van Sluys et al., 2002). Para analisar a relação entre as integrases encontradas em Xf com as integrases encontradas em bacteriófagos, foi adaptada uma ferramenta de bioinformática, denominada phage-navigator-comparative (adaptada do programa SABIÁ-Comparative), que utiliza metodologia de construção de melhores alinhamentos locais bidirecionais (BBH). Por esta ferramenta, foi possível associar por metodologia de BBH todas as integrases de $\mathrm{Xf}$ com as integrases encontradas em 402 genomas de bacteriófagos. A partir da construção dos conjuntos de BBHs, as integrases de fagos foram divididas em nove conjuntos, apresentados na tabela 4.5. Os conjuntos 9 e 10 são exclusivos das integrases de Xf, e são formados por fragmentos de integrases. O conjunto 5 é composto por 39 integrases de fagos e 2 integrases de IGs de Xf (compreendendo todas as integrases de Xf, exceto os fragmentos). A partir do conjunto 5, foi gerada uma árvore de distância pelo método de neighbor-joining (Figura 4.12), onde é possível visualizar a proximidade e associação das integrases de Xf com as integrases de bacteriófagos.

Tabela 4.5. Conjunto de BBHs formados a partir de análise pelo phage-navigator-comparative *

\begin{tabular}{cc}
\hline Conjunto & Quantidade \\
\hline 1 & 2 \\
2 & 22 \\
3 & 2 \\
4 & 3 \\
$\underline{\mathbf{5}}$ & $\underline{\mathbf{1 8 4}}$ \\
6 & 4 \\
7 & 2 \\
8 & 2 \\
$\underline{\mathbf{9}}$ & $\underline{\mathbf{7}}$ \\
$\underline{\mathbf{1 0}}$ & $\underline{\mathbf{2}}$ \\
$\mathbf{1 1}$ & 22 \\
\hline TOTAL & $\mathbf{2 5 2}$ \\
\hline
\end{tabular}

* Os conjuntos foram determinados pelo parâmetro de $60 \%$ de cobertura mínima de alinhamento e e-value de $10^{-5}$. Em destaque, os conjuntos contendo as integrases de fagos de Xf . 


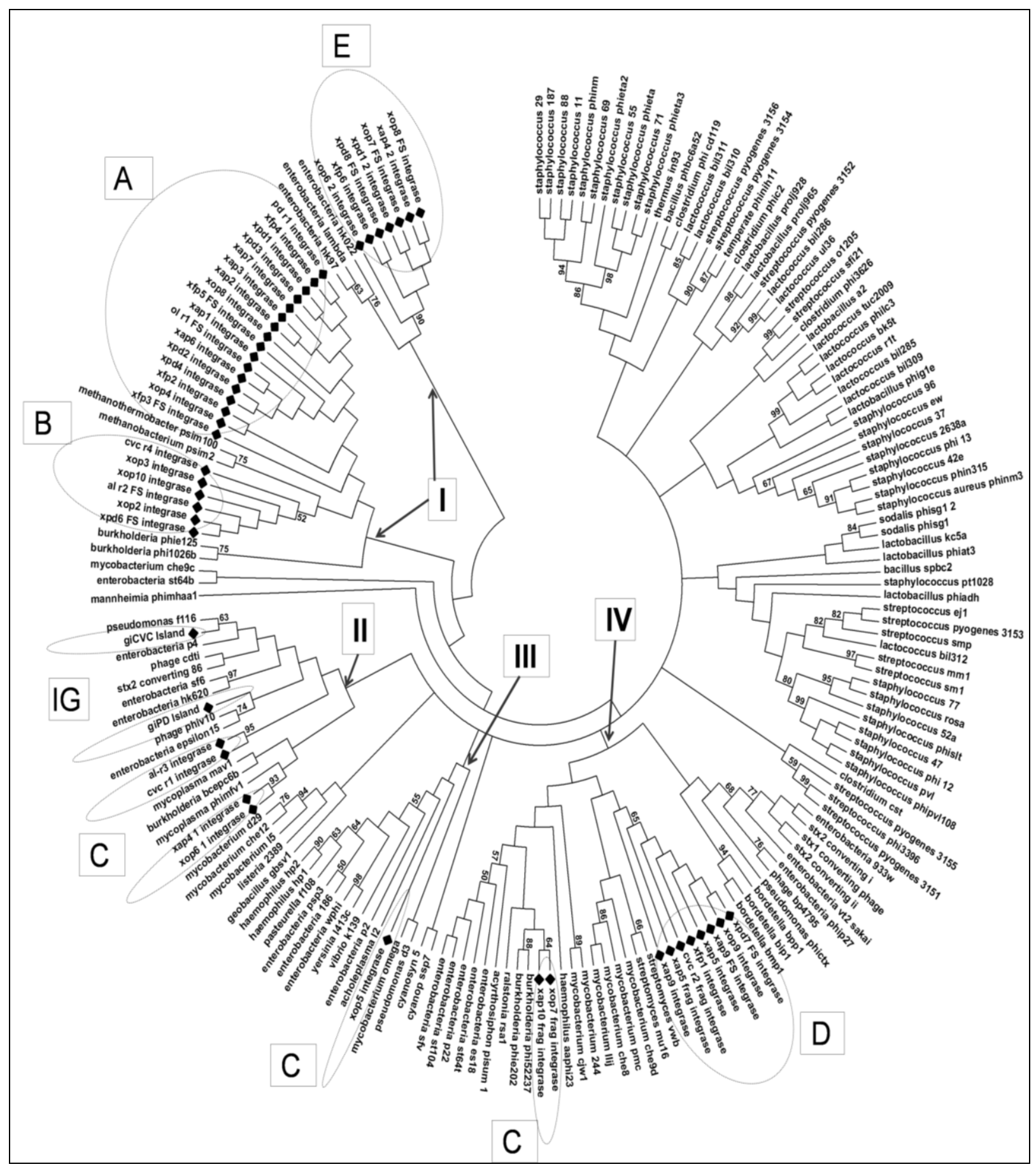

Figura 4.12. Árvore de distância pelo método de neighbor-joining (com teste de bootstrap de 1.000 réplicas) do conjunto de integrases $\mathbf{5}$. Os losangos em preto informam o posicionamento das integrases de fagos e IGs de Xf. As caixas de texto indicam a qual classificação as integrases de Xf pertencem (conforme figura 4.3 ; círculos pontilhados). As setas indicam onde as integrases de Xf se associam com integrases de fagos que infectam outros microorganismos.

As integrases de Xf apresentam associação direta com integrases contidas em genomas de fagos que apresentam DNA dupla fita, sem estágio de RNA (indicação em setas pretas na figura 4.12) da ordem dos Caudovirales, dividida em três famílias: Myoviridae (fagos com cauda 
retrátil), Podoviridae (fagos com caudas curtas), Siphoviridae (fagos com longas caudas nãoretráteis) e também pelos Caudovirales não classificados (Tabela 4.6). Também foi identificada uma única associação com o gênero dos Plasmaviridae (Plasmavirus). As demais integrases virais que não apresentam associação direta com as integrases de Xf são integrases pertencentes na grande maioria (> 80\%) a fagos do gênero dos Siphoviridae que infectam bactérias gram positivas. A fim de estabelecer uma correlação entre as integrases de Xf com as integrases de fagos e possivelmente com os fagos completos, cada ramo da árvore (indicados pelas setas na figura 4.12, e denominados I, II, III e IV) foi analisado individualmente, assim como as integrases de fagos que estão localizadas na árvore em posição intermediárias, entre os ramos I, II, III e IV, sendo os resultados apresentados a seguir.

Tabela 4.6. Gêneros de fagos que apresentam integrases associadas às integrases de Xf (Ordem Caudovirales) (fonte: ICTVdB - The Universal Virus Database, version 4)

\begin{tabular}{|c|c|c|c|}
\hline Caudovirales: Famílias: & Myoviridae & Podoviridae & Siphoviridae \\
\hline & T4-like & T7-like & Lambda-like \\
\hline & - P1-like & - P22-like & T1-like \\
\hline \multirow[t]{4}{*}{ Principais gêneros } & - $\quad$ P2-like & Phi29 & - T5-like \\
\hline & - Mu-like & & - $\quad$ L5-like \\
\hline & - $\quad$ SPO1-like & & - c2-like \\
\hline & - $\quad$ PhiH-like & & - M1-like \\
\hline
\end{tabular}

\subsubsection{Ramo I}

O ramo I contém o maior número de integrases de Xf (integrases classificadas como $\mathbf{A}$, B e E), estando associado às integrases de fagos da família Siphoviridae, em particular com integrases presentes em fagos do tipo lambda (Figura 4.13). As integrases classificadas como A e B estão associadas principalmente às integrases do fago que infecta Methanobacterium (psiM2) e ao profago de Methanothermobacter wolfeii (psiM100), ambas árqueabactérias. Análises comparativas entre psiM2 e psiM100 indicam que apresentam média de 27 kb compartilhando 70,8\% de identidade de nucleotídeos, e que são fagos defectivos, originados a partir de deleções do fago psiM1 (Luo et al., 2001). Também apresentam associação com as integrases dos fagos phiE125 e phi1026b que infectam a bactéria Burkholderia, sendo que estes fagos apresentam média de $49 \mathrm{~kb}$. O fago phiE125 utiliza como sítio de inserção um tRNA-prolina, apresenta organização genética muito similar a fagos e profagos do gênero lambda, apesar de apresentar genes relacionados à replicação e lisogênese diferentes; portanto, é considerado como um novo membro do grupo dos fagos lambda (Woods et al., 2002) (Figura 4.13). 
Análises de alinhamento global e local não apontam para similaridade entre as seqüências de nucleotídeos dos fagos psiM2, psiM100, phiE125 e phi1026b com os profagos de Xf que contém as integrases classificadas como $\mathbf{A}$ e $\mathbf{B}$, indicando que a princípio a associação é restrita apenas às integrases.

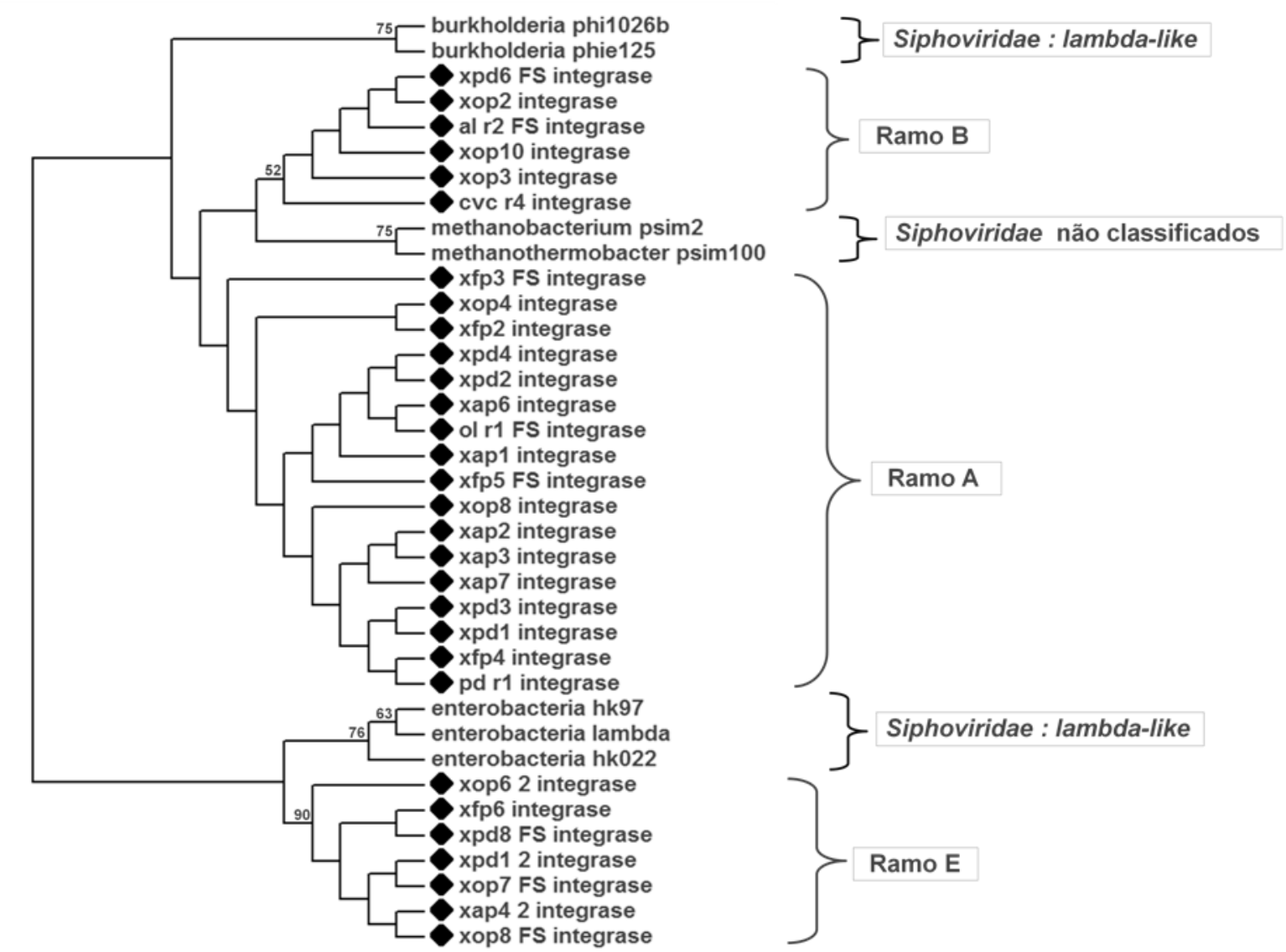

Figura 4.13. Árvore de distância pelo método de neighbor-joining (com teste de bootstrap de 1.000 réplicas) referente ao ramo $\mathbf{I}$.

As integrases classificadas no ramo $\mathbf{E}$ estão associadas principalmente às integrases dos fagos HK022, HK97 e lambda, que infectam enterobactérias, em particular Escherichia coli. Quando comparados HK022 e HK97 com outros fagos do gênero lambda, os resultados apontam que se tratam de mosaicos genéticos e que também carregam genes provenientes da bactéria por processos de erros de transdução, indicando que processos de transferência gênica lateral podem ser o principal agente no mecanismo de diversificação neste grupo de vírus. Isso sugere um modelo de evolução nestes fagos relacionado com a diversidade de processos de recombinações homóloga e ilegítima (Juhala et al., 2000) (Figura 4.13).

As regiões de profagos que contém as integrases classificadas como $\mathbf{E}$ não apresentam similaridade de seqüência por alinhamento global e local com os fagos HK022, HK97 e lambda, indicando mais uma vez que a princípio a associação é restrita apenas às integrases. 


\subsubsection{Ramo II}

O ramo II contém integrases de Xf classificadas como $\mathbf{C}$ e IGs, sendo que se associam com integrases de fagos das três famílias (Siphoviridae, Myoviridae e Podoviridae) (Figura 4.14). As integrases xop6_1 e xap4_1, classificadas como $\mathbf{C}$, estão associadas principalmente às integrases dos fagos BCEPC6B (que apresenta $42 \mathrm{~kb}$ e infecta Burkholderia cepacia) e phiMFV1 e MAV1, que apresentam em média $15 \mathrm{~kb}$ com 95\% de similaridade de sequiência por alinhamento global, e infectam Mycoplasma fermentans e Mycoplasma arthritidis, respectivamente. As principais diferenças entre os fagos phiMFV1 e MAV1 são que MAV1 apresenta uma ORF codificando uma lipoproteína, responsável por ocasionar artrite em ratos, enquanto phiMFV1 apresenta uma ORF que codifica uma proteína de superfície, mas ambas não estão relacionadas ao ciclo biológico do fago e sim são responsáveis por promover adaptação de Mycoplasma ao meio, indicando que estes fagos apresentam um importante papel na evolução genômica deste gênero (Röske et al., 2004; Voelker e Dybvig, 1999).

As integrases cvc-r1 e al-r3, também classificadas como $\mathbf{C}$, apresentam proximidade com as integrases de IGs, sendo que a integrase giPD está relacionada ao fago epsilon15 de Salmonella e ao fago phiV10, que apresentam 39.104 pb e 39.671 pb respectivamente. O fago epsilon15 apresenta GC\% de 50\%, é formado por 51 ORFs, e é estruturalmente similar a diversos fagos, em especial ao vírus do herpes humana, sugerindo um ancestral em comum (Jiang et al., 2006). Já o fago phiV10 apresenta GC\% de $48 \%$ sendo composto por 56 ORFs; apresenta habilidade lisogênica em Escherichia coli, e é utilizado em estudos de transgênese neste gênero de bactéria (Waddell e Poppe, 2000). A análise de alinhamento global indicou que giPD apresenta menos de $40 \%$ de identidade com estes fagos.

A árvore de distância indica que a integrase de giCVC está relacionada principalmente à integrase do fago F116 de Pseudomonas, que apresenta 65.195pb e tem GC\% de 63,2\%. O fago F116 apresenta característica de duplicação em forma epissomal, como um plasmídeo, durante o desenvolvimento do ciclo lisogênico (Miller et al., 1977) e apresenta habilidade de transdução generalizada, sendo que em algumas ocasiões incorpora DNA da bactéria durante a montagem da partícula viral. Ele é composto por 70 ORFs, sendo que apenas 16 apresentam similaridade com genes de fagos e com genes específicos do gênero Pseudomonas (Byrne e Kropinski, 2005). Análises de alinhamento global indicam que a seqüencia de nucleotídeos completa de F116 apresenta $50 \%$ de identidade com a sequiência de nucleotídeos completa de giCVC; porém, as regiões de similaridade estão restritas apenas a pequenas porções de nucleotídeos, e eles não compartilham outras ORFs além das integrases. A giCVC também está relacionada com integrases presente nos fagos P4, STX2-86, CDTI, HK620 e SF6, que apresentam 11.624 pb, 
60.238 pb, 47.021 pb, 38.297 pb e 39.043 pb respectivamente, sendo que HK620 e SF6 infectam Escherichia coli e Shigella flexneri respectivamente, onde apresentam similaridade de $34 \%$ entre suas seqüências de nucleotídeos e são mosaicos genéticos (Casjens et al., 2004). O fago STX286 apresenta capacidade de transdução generalizada, enquanto CDTI é considerado um fago lítico, e apenas contém resquícios de ORFs relacionadas com o ciclo lisogênico (Clark et al., 2001; Dhillon et al., 1998; Tremblay e Moineau, 1999).
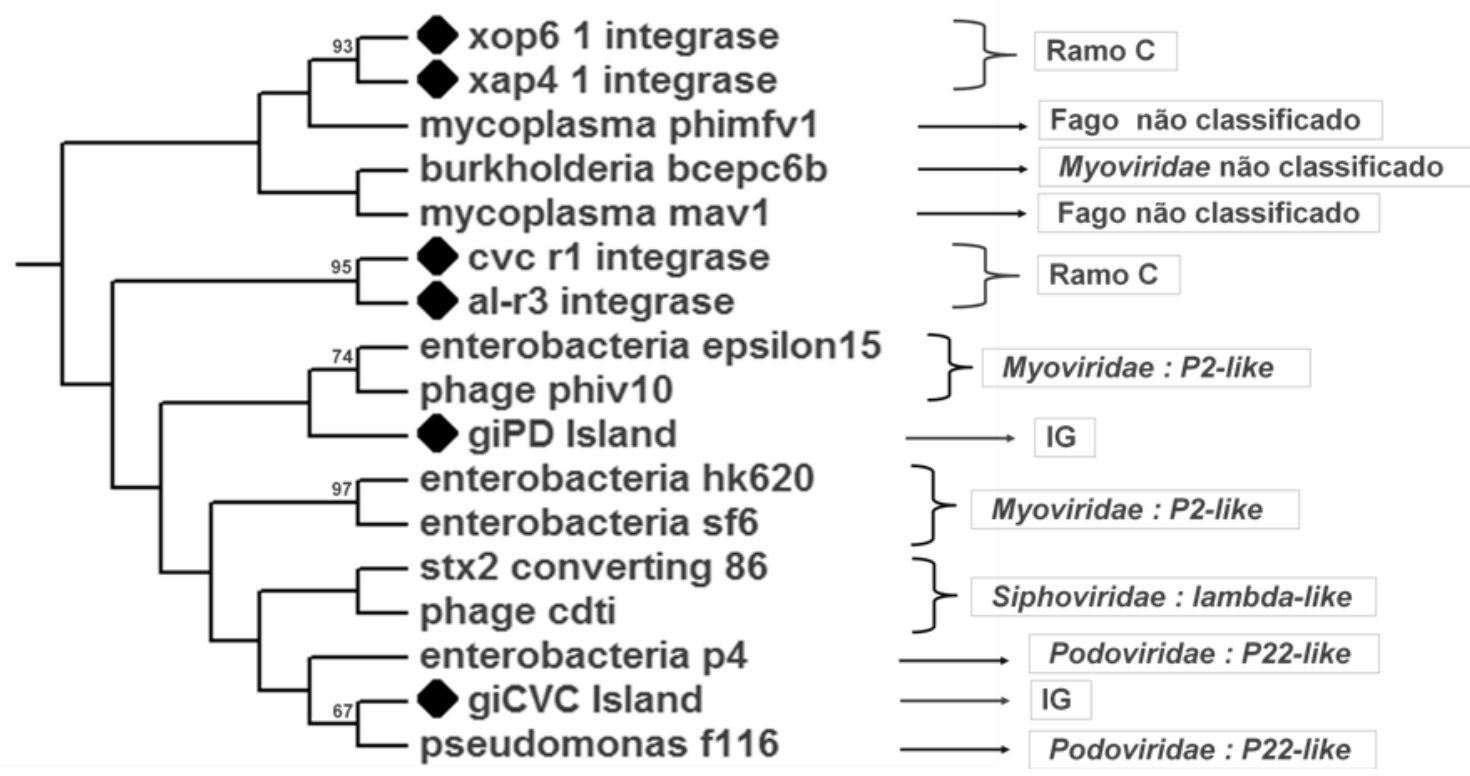

Figura 4.14. Árvore de distância pelo método de neighbor-joining (com teste de bootstrap de 1.000 réplicas) referente ao ramo II.

\subsubsection{Ramo III}

A integrase xop5, classificada como $\mathbf{C}$, figura como única integrase de Xf no ramo III, indicando mais uma vez tratar-se de uma integrase diferenciada dentre as estudadas nas quatro linhagens; ela apresenta-se associada a integrases de fagos das famílias Siphoviridae, Myoviridae e Plasmaviridae (Figura 4.15).

Dentre as integrases de fagos que se associam com xop5, destaca-se a integrase do fago D3, que apresenta aproximadamente 56 kb e infecta o gênero Pseudomonas; a disposição de suas ORFs apresenta organização similar à encontrada no fago lambda, onde sua característica principal está relacionada à capacidade conversão de sorotipo em seu hospedeiro, Pseudomonas aeruginosa (Kropinski, 2000). O fago OMEGA apresenta mosaicismo genético (Pedulla et al., 2003), enquanto o fago L2 apresenta apenas $11 \mathrm{~kb}$ e infecta o gênero Mycoplasma (Maniloff et 
al., 1994). Os demais fagos: P2, K139, Wphi, 186, PSP3, F108, HP1 e HP2 apresentam tamanho médio de 30 kb, e infectam as enterobactérias Vibrio cholerae, Pasteurella multocida e o gênero Haemophilus, respectivamente. A literatura cita que F108, HP1 e HP2 apresentam identidade em suas sequiências de nucleotídeos, indicando evidência de divergência recente entre estes fagos (Campoy et al., 2006; Williams et al., 2002).

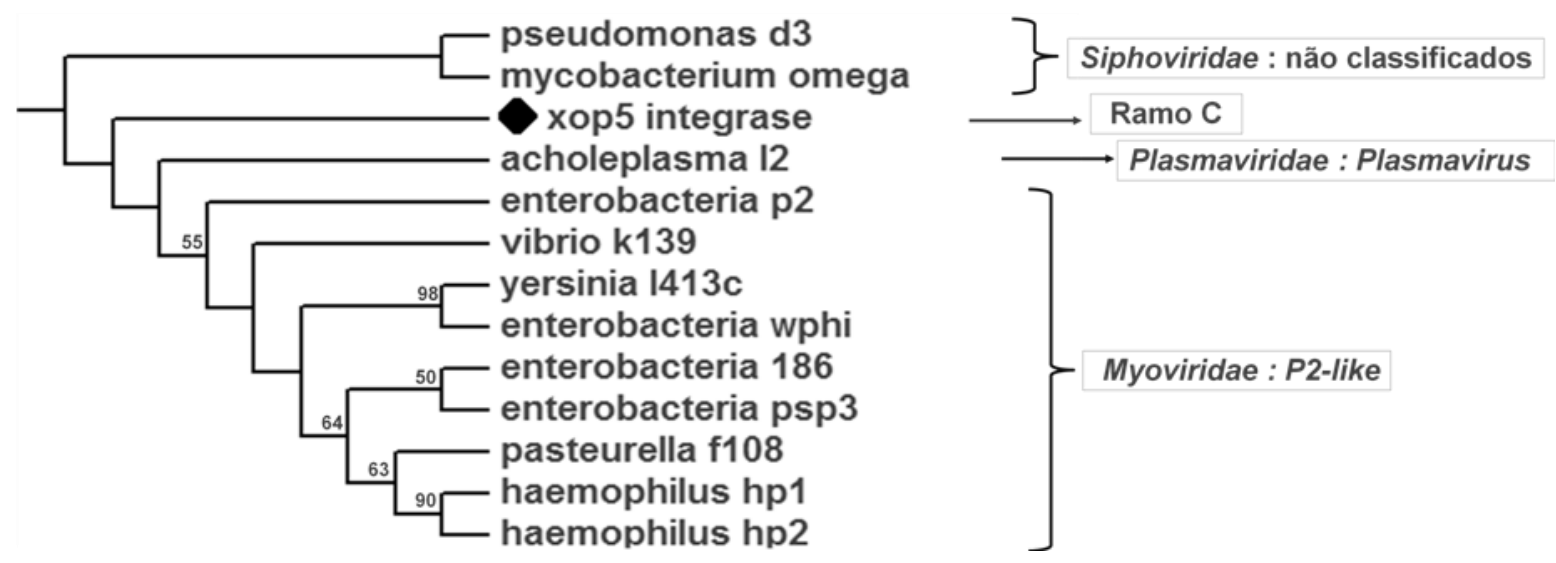

Figura 4.15. Árvore de distância pelo método de neighbor-joining (com teste de bootstrap de 1.000 réplicas) referente ao ramo III.

\subsubsection{Ramo IV}

O ramo IV contém integrases de Xf classificadas como $\mathbf{C}$ e $\mathbf{D}$, sendo que estas se associam com integrases de fagos das três famílias (Siphoviridae, Myoviridae e Podoviridae) (Figura 4.16).

As integrases $\mathbf{C}$ são fragmentos de integrases que estão associadas principalmente com as integrases dos fagos phi52237, phiE202 e RSA1, fagos que apresentam tamanho médio de $40 \mathrm{~kb}$ e responsáveis por infectar o gênero Ralstonia (phi52237 e phiE202) e Burkholderia (RSA1). Também estão próximas ao fago PISUM1, de $38 \mathrm{~kb}$, responsável por infectar um endossimbionte de ervilhas, Acyrthosiphon pisum (van der Wilk et al., 1999). O fago aaphi23 infecta a bactéria Actinobacillus actinomycetemcomitans, e segundo a literatura este fago é agente etiológico de inflamação de gengivas em humanos, responsável por transduzir marcadores e genes de resistência para antibióticos in vitro (Resch et al., 2004). Análises genômicas apontam para similaridade de nucleotídeos de aaphi23 com diversas regiões de fagos em Xf (principalmente com xfp3, xfp4, xpd2, xop9, xap3, xap7 e xap9); portanto, além de compartilhar sua integrase, também compartilham diversas ORFs, podendo indicar a existência de um ancestral em comum. 
Análises genômicas entre aos fagos ST104, ES18, ST64T, P22 e STF indicam um tamanho médio de $40 \mathrm{~kb}$; eles estão relacionados a infecções em E. coli, Salmonella typhimurium e Shigella flexneri. ST104, ST64T e P22 apresentam similaridade em suas seqüências de nucleotídeos e genes em comuns com os fagos HK97 e lambda; ES18 apresenta ainda habilidade para desencadear transdução generalizada (Alisson et al., 2002; Casjens et al., 2005; Mmolawa et al., 2003; Tanaka et al., 2004).

As integrases classificadas como $\mathbf{D}$ estão associadas com integrases dos fagos VWB e MU16 (que infectam Streptomyces venezuelae e Streptomyces aureofaciens respectivamente, apresentando média de $40 \mathrm{~kb}$ ), e também com as integrases dos fagos CHE9D, PMC, CHE8, IIJJ 244 e CJW1 (que infectam exclusivamente o gênero Mycobacterium, apresentando um genoma com características mosaicas que varia de $38 \mathrm{~kb}$ a $75 \mathrm{~kb}$ ). Alguns deles codificam tRNAs, que a princípio poderiam ser transferidos para a bactéria no processo de recombinação sítio-específica. Análises comparativas com os demais fagos de Mycobacterium também apontam como mosaicos genéticos, indicando a ocorrência de recombinação ilegítima no processo de transferência gênica lateral nesta família de fagos (Ford et al., 1998; Pedulla et al., 2003).

As integrases classificadas como $\mathbf{C}$ e $\mathbf{D}$ também estão relacionadas com integrases dos fagos BIP1, BMP1 e BPP1 que infectam Bordetella e apresentam média de 40 kb; são híbridos dos fagos P22 e T7, capazes de transduzir marcadores genéticos in vitro, utilizando-se para estes fins modelos animais (Liu et al., 2004). Também estão relacionadas com o fago phiCTX que infecta Pseudomonas aeruginosa, sendo que a organização genômica e metade das ORFs de phiCTX são similares a ORFs do fago P2 (média de 65,8\% de identidade), indicando que phiCTX é um fago do tipo P2 adaptado para o gênero Pseudomonas (Nakayama et al., 1999). Também estão relacionadas aos fagos STX1, STX2_1 e STX2_2, 933W, SAKAI, BP4795 e phiP27, que infectam diversas espécies de E. coli e Shiguella, apresentando média de $60 \mathrm{~kb}$; o fago $933 \mathrm{~W}$ apresenta três cópias de tRNAs. Segundo a literatura, trata-se de fagos temperados que carregam toxinas envolvidas em patologias em humanos (Shiga toxina 1 e 2). Suas principais diferenças estão relacionadas ao conjunto de genes relacionados com a regulação e replicação (genes: cI, cII, cIII, N, cro, O e P), indicando que eventos de recombinação entre esse grupo de fagos são freqüentes (Miyamoto et al., 1999; Plunkett et al., 1999; Recktenwald e Schmidt, 2002; Sato et al., 2003). 

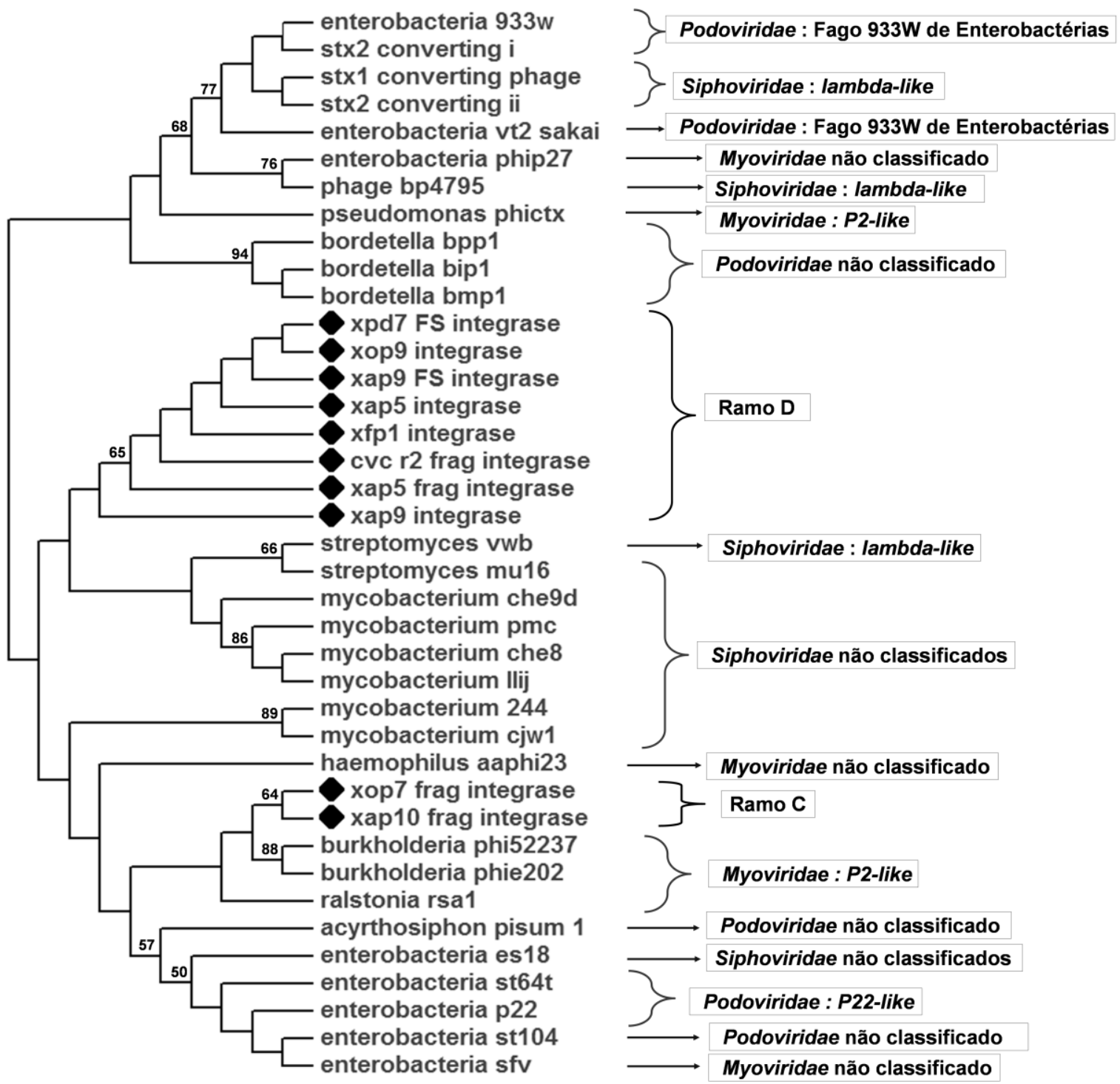

Figura 4.16. Árvore de distância pelo método de neighbor-joining (com teste de bootstrap de 1.000 réplicas) referente ao ramo IV.

Algumas integrases de fagos estão localizadas entre os ramos I, II, III e IV, e por estarem próximas aos ramos onde as integrases de Xf estão contidas, também foram analisadas, sendo descritas a seguir:

(1) As integrases dos fagos CHE9C, ST64B e phiMHAA1, estão localizadas entre os ramos I e II (Figura 4.12), sendo que estes fagos infectam Mycobacterium, Salmonella typhimurium e Mannheimia haemolytica respectivamente. O fago CHE9C é um mosaico genético (Pedulla et al., 2003), enquanto o fago ST64B apresenta organização genômica similar ao fago lambda, sendo que a maioria dos genes que codificam proteínas estruturais de cauda é similar aos genes do fago Mu. Porém, segundo a literatura, não são expressos devido à inserção 
de genes relacionados à virulência; este fato, associado à inabilidade de formação de placas em meio de cultura, quando inoculado em vários isolados, sugere que o ST64B é um fago defectivo que adquiriu estabilidade no cromossomo. Por outro lado, os genes que codificam para estruturas do capsídeo apresentam similaridade com os genes dos fagos HK022 e HK97 e para diversos outros fagos do tipo lambda que infectam os gêneros Escherichia, Pseudomonas, Agrobacterium, Caulobacter, Mesorhizobium e Streptomyces. Estes resultados sugerem que o fago ST64B é um mosaico genético que adquiriu porções de seu genoma provenientes de outras bactérias fora do gênero Salmonella (Mmolawa et al., 2003). E, por último, o fago phiMHAA1 apresenta $34.525 \mathrm{pb}$, sendo que $46 \%$ de seu proteoma é similar ao fago P2 (Highlander et al., 2006).

(2) As integrases dos fagos D29, CHE12, L5, 2389 estão localizadas entre os ramos II e III (Figura 4.12), sendo que estes fagos infectam os gêneros Mycobacteria e Listeria. A comparação entre os fagos D29, CHE12 e L5 aponta-os como mosaicos genéticos, sendo a principal diferença entre eles associadas à deleção do gene repressor (aproximadamente 3,5 kb) em D29, tornando-o um fago exclusivamente lítico (Ford et al., 1998). As integrases de D29 e L5, para efetuarem a recombinação sítio-específica, necessitam da transcrição, pela bactéria (Mycobacterium), de um fator de integração chamado de mIHF, formando um complexo de interação proteína-proteína denominado de intrasoma (Pena et al., 1999). As integrases pertencentes a D29 e L5 apresentam potencial interesse biotecnológico, pois são capazes de realizar recombinação sítio-específica in vitro (Lee e Hatfull, 1993).

(3) Integrases que infectam cianobactérias (SSP7 e Cyanosyn5) (Figura 4.12) estão localizadas entre os ramos III e IV. O fago SSP7 infecta o gênero Prochlorococcus, apresentando tamanho de $44 \mathrm{~kb}$, sendo que em seu genoma são identificadas ORFs relacionadas à fotossíntese, indicando que este fago apresenta capacidade de transduzir genes relacionados à capacidade de adaptação ao meio ambiente (Sullivan et al., 2005). O fago Cyanosyn5 infecta o gênero Synechococcus, apresenta tamanho de $46 \mathrm{~kb}$ e tem constituição similar a fagos do tipo T7 (Pope et al., 2007).

(4) A integrase do fago CST que infecta a bactéria Clostridum botulinum e as integrases dos fagos 3155, phi3396 e 3151 que infectam o gênero Streptococcus estão delimitando as integrases de Xf presentes dos quatro ramos com as demais integrases de fagos (Figura 4.12). O fago CST, apresenta-se, segundo a literatura, em forma de um profago circular, sendo que seu genoma contém uma ORF responsável por codificar a neurotoxina botulínica (Sakaguchi et al., 2005). Os fagos 3155, phi3396 e 3151 apresentam tamanho médio de 39 kb e são responsáveis pelas principais diferenças genômicas entre linhagens diferentes de Streptococcus do grupo A 
por codificar toxinas responsáveis por patologias em humanos (Beres et al., 2002; Davies et al., 2007).

De modo geral, os resultados acima mostram que as integrases de Xf apresentam associação com integrases de fagos que, em sua grande maioria, são mosaicos genéticos próximos ou pertencentes à família dos fagos lambda e que apresentam capacidade de realizar processos de transdução generalizada ou especializada, desempenhando papel fundamental na evolução e diferenciação genômica dos hospedeiros que infectam.

Por outro lado, as análises de similaridade entre as seqüências de nucleotídeos dos fagos acima mencionados contra os profagos de Xf apontam que, na maioria dos casos, apenas as integrases ou um número restrito de ORFs são compartilhadas, indicando uma enorme diversidade genética na população de fagos, em particular nos fagos de Xf. Isso demonstra que os bancos de dados de genomas de partículas de fagos ainda não apresentam um fago com similaridade aos profagos de Xf para que possa ser sugerido um ancestral comum. E, por último, a organização das integrases classificadas como $\mathbf{C}$ na árvore de distância sugere que este grupo é mais diverso das demais integrases de Xf; em particular, a integrase xop5 parece ser uma integrase com constituição diferente das demais integrases de Xf. 


\subsection{ASSOCIAÇÃO DAS INTEGRASES DE Xf COM BACTÉRIAS}

Com o intuito de analisar a relação entre as integrases encontradas em $\mathrm{Xf}$ com as integrases encontradas em regiões de profagos e IGs provenientes de outros microorganismos, foi gerada uma árvore de distância por método de neighbor-joining com 84 integrases homólogas, exclusivas de genomas bacterianos. Por esta árvore é possível visualizar a localização de cada ramo de integrase de Xf previamente classificado. De modo geral, a árvore indica que os principais homólogos são integrases de proteobactérias, e as integrases do ramo $\mathbf{C}$ são as mais diversas (Figura 4.17).

As integrases do ramo $\mathbf{A}$ apresentam similaridade de resíduos de aminoácidos (considerando-se uma cobertura maior ou igual a 90\% do alinhamento pelo programa BLASTP) com beta- e gama-proteobactérias que também não apresentam o resíduo $H[308]$ na posição esperada, como Nitrosomonas eutropha, Actinobacillus pleuropneumoniae e duas espécies de Pseudomonas. Segundo Stein e colaboradores (2007), N. eutropha é uma bactéria que realiza oxidação anaeróbica de amônia, cujo cromossomo apresenta diversos rearranjos quando comparado a outras espécies de Nitrosomonas; estes rearranjos são ocasionados pela inserção de profagos e plasmídeos, sendo que também possui uma ilha genômica linhagem-específica, apresentando assim características genômicas similares a Xf. A integrase de $A$. pleuropneumoniae está presente em uma ilha genômica específica para esta espécie (Xu et al., 2008), enquanto $P$. syringae, que também é um patógeno de plantas, apresenta esta integrase relacionada a uma região de profago com composição e organização de ORFs que assemelha-se ao genoma de um fago do tipo lambda que também infecta Shewanella oneidensis (Feil et al., 2005).

As integrases do ramo $\mathbf{B}$ apresentam similaridade de resíduos de aminoácidos (cobertura maior ou igual a 90\%) com três espécies de Pseudomonas. O genoma de P. putida apresenta quatro regiões de profagos, sendo uma bactéria habitualmente isolada do solo (Nelson et al., 2002). P. entomophila também é uma bactéria isolada de solo, sendo que quando ingerida por Drosophila melanogaster é capaz de provocar sua morte; apresenta ao menos três pequenas regiões de profagos que assemelham-se a fagos do tipo lambda e Mu (Vodovar et al., 2006). $P$. fluorescens é um comensal de plantas, apresenta uma ilha genômica e sete regiões relacionadas a profagos que apresentam constituição híbrida similar a fagos do tipo P2 e lambda; estas regiões representam aproximadamente $268 \mathrm{~kb}(3,78 \%)$ do genoma, e carregam ORFs que podem codificar enzimas relacionadas a conversão de sorotipo e bacteriocinas (Paulsen et al., 2005). 


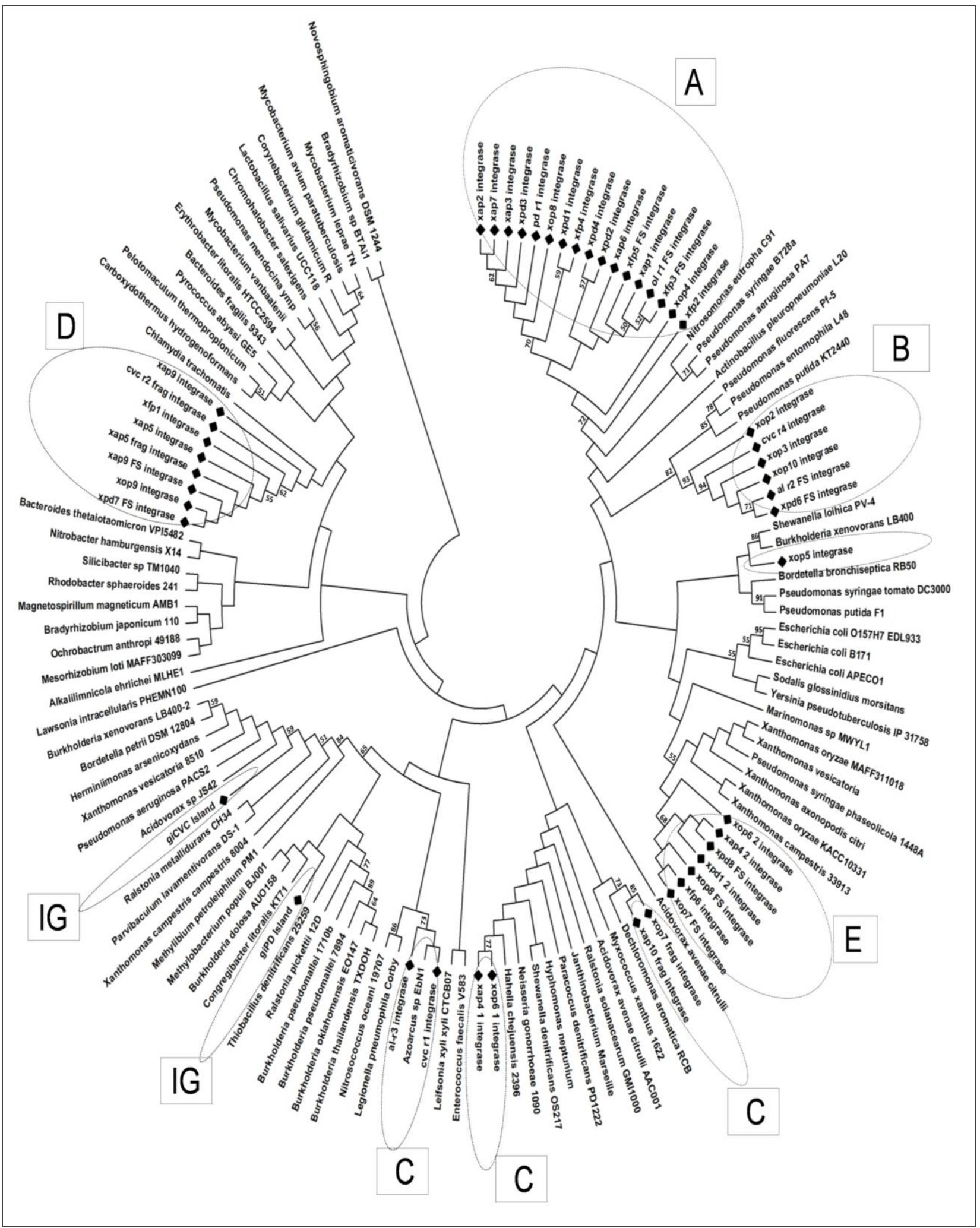

Figura 4.17. Árvore de distância pelo método de neighbor joining ( com bootstrap de 1.000 réplicas) das integrases de Xf e 84 ortólogos identificados por BLAST, exclusivos de genomas procariontes. As caixas de texto indicam a qual classificação as integrases de Xf pertencem (conforme Figura 4.3 e indicadas nesta figura pelos círculos pontilhados). 
A integrase xop5 é a única integrase completa em que está distante das demais integrases pertencentes ao seu ramo (C), apresentando $35 \%$ e $31 \%$ de identidade com as integrases das bactérias Shewanella loihica e Pseudomonas syringae pv. tomato, respectivamente (as demais bactérias ilustradas pela árvore apresentam identidade inferior a 30\%). P. syringae pv. tomato é um patógeno de Arabidopsis thaliana e de tomate, sendo que suas regiões de profagos representam $107 \mathrm{~kb}(1,67 \%)$ de seu genoma (Buell et al., 2003); por outro lado, não há na literatura informação a respeito dos elementos genéticos móveis de $S$. loihica.

As demais integrases completas do ramo $\mathbf{C}$ apresentam similaridade de resíduos de aminoácidos (cobertura maior ou igual a $60 \%$ do alinhamento) com integrases presentes em Hahella chejuensis, uma bactéria isolada de ecossistemas aquáticos, Neisseria gonorrhoeae, patógeno de humanos, e outras proteobactérias (para xap4_1 e xop6_1), enquanto al-r3 e cvc-r1 são relacionadas a regiões remanescentes de profagos, onde apresentam similaridade de resíduos de aminoácidos (cobertura maior ou igual a $60 \%$ do alinhamento) com integrases presentes em Azoarcus sp., uma bactéria fixadora de nitrogênio isolada de arroz e outra gramíneas; Legionella pneumophila, patógeno de humanos; e Nitrosococcus oceani, que também é isolado de ecossistemas aquáticos.

As integrases do ramo $\mathbf{E}$ apresentam similaridade de seqüências de aminoácidos (cobertura maior ou igual a 90\% do alinhamento) com integrases presentes em Xanthomonas oryzae pv. oryzae, Xanthomonas campestris pv. campestris, Xanthomonas axonopodis pv. citri, Xanthomonas campestris pv. vesicatoria e Pseudomonas syringae pv. phaseolicola, todos fitopatógenos. Este resultado indica que as integrases associadas às regiões relacionadas a profagos deste grupo apresentam origem em comum com as integrases de fagos presentes no gênero Xanthomonas, que é considerado grupo irmão de Xf juntamente com Stenotrophomonas, entre as gama-proteobactérias.

As integrases do ramo $\mathbf{D}$ apresentam similaridade de resíduos de aminoácidos (cobertura maior ou igual a $60 \%$ do alinhamento) com Chlamydia trachomatis, patógeno de humanos; Pyrococcus abyssi, arqueabactéria isolada de fossas hidrotermais; Magnetospirillum magneticum, isolada de ecossistemas aquáticos; e Bradyrhizobium japonicum, bactéria fixadora de nitrogênio isolada de grãos de soja; duas espécies de Mycobacterium relacionadas a patologias em humanos, e com outras proteobactérias com identidade inferior a $60 \%$.

A figura 4.17 ilustra que as integrases de IGs apresentam-se próximas às do ramo $\mathbf{C}$, sendo que para uma análise mais detalhada das integrases de IGs foi gerada uma árvore de distância pelo método de neighbor-joining, comparando as integrases de ilhas às 40 primeiras integrases homólogas presentes no banco de dados do GenBank (por metodologia de BLASTP) (Figura 4.18). 


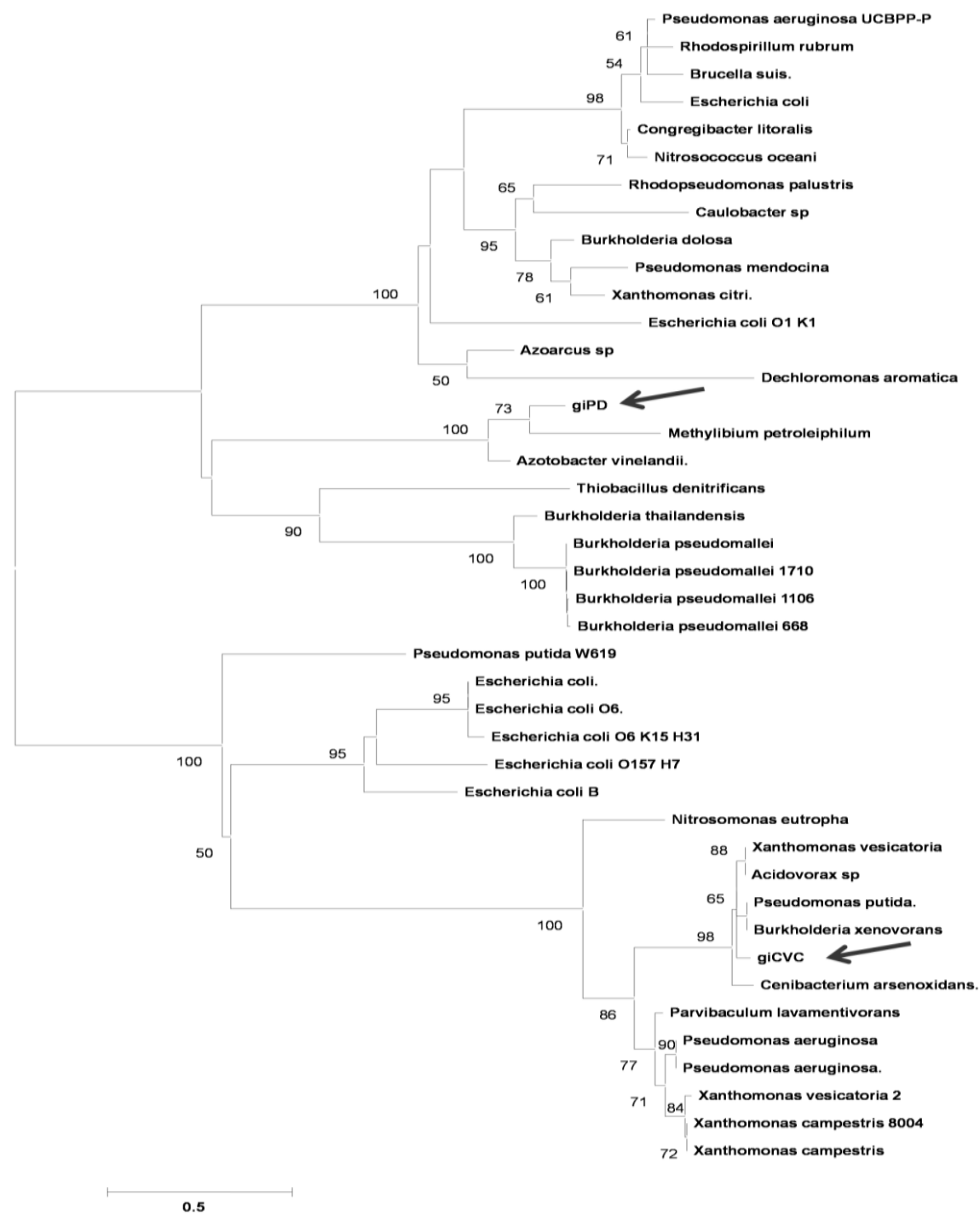

Figura 4.18. Árvore de distância pelo método de neighbor joining (com bootstrap de 1.000 réplicas) das integrases de ilhas genômicas e 40 ortólogos identificados por BLAST, exclusivos de genomas procariontes. Os números nos nós internos se referem ao valor percentual do bootstrap. As setas indicam a posição de giCVC e giPD na árvore.

Os resultados apresentados na árvore de distância indicam que giCVC teria uma origem comum com integrases presentes em ilhas de patogenicidade encontradas em diversas enterobactérias, em particular nas linhagens de Escherichia coli que causam doenças em humanos. Também mostra que está presente predominantemente em gama-proteobactérias, em particular em regiões de profagos e IGs, sendo os homólogos mais próximos integrases encontradas nos genomas de Xanthomonas campestris pv. vesicatoria, Pseudomonas aeruginosa PACS2, Burkholderia xenovorans e Pseudomonas putida, com média de $92 \%$ de identidade. A giPD apresenta principais homólogos em Methylibium petroleiphilum, isolada em compostos derivados do petróleo, sendo capaz de degradar anéis aromáticos (benzeno, tolueno e xileno) e Azotobacter vinelandii, uma bactéria fixadora de nitrogênio, com média de $70 \%$ de identidade entre suas seqüências de aminoácidos. 


\subsection{SÍTIOS DE INSERÇÃO DE INTEGRASES DE FAGOS ASSOCIADOS A tRNAS}

As integrases de fagos utilizam tRNAs como sítio preferencial de integração no genoma; como geralmente os tRNAs representam menos de $2 \%$ de um genoma bacteriano, há um restrito universo de sítios preferenciais para integração (Williams, 2002). Com o intuito de verificar uma possível associação entre os tRNAs como sítio preferencial de inserção pelas integrases, foi realizado um mapeamento dos tRNAs e de seus fragmentos nas quatro linhagens.

As quatro linhagens de Xf apresentam os mesmos 49 tRNAs, porém distribuídos em ordem distinta (Tabela 4.7). Quando se compara o posicionamento dos tRNAs entre as quatro linhagens, constata-se que Xf-OL e Xf-PD apresentam maior colinearidade de posicionamento de tRNAs em relação às outras linhagens, e que os pontos de divergência de posicionamento de tRNAs entre as quatro linhagens encontram-se na região que corresponde a $900 \mathrm{~Kb}$ a 1,8 Mb. Os conjuntos de tRNAs que estão rearranjados (invertidos e translocados) indicam o impacto da inserção de fagos ao longo do genoma, em particular na linhagem Dixon (Xf-AL), onde a partir da posição 170.260 já ocorre a inserção de fago em seu genoma responsável por um rearranjo, quando comparada às outras linhagens. Tanto a linhagem Xf-CVC como Xf-AL apresentam uma região remanescente muito próxima à região de origem de replicação; esta região está ao lado de um bloco de tRNAs (PRO, ARG, HIS e LYS) associado a fragmento de integrase, indicando que esta região relacionada a profagos pode ter sofrido uma degeneração.

Através do estudo de mapas genômicos, onde a posição de tRNAs, IGs e regiões de profagos estão demarcados, é possível identificar sítios de inserção no genoma relacionados a tRNAs. As figuras apresentadas no Anexo IV (A, B, C e D) ilustram os mapas genômicos de posicionamento de IGs e regiões de profagos nas quatro linhagens. Os resultados mostram que oito tipos de tRNAs estão localizados em bordas de regiões de profagos e IGs (Tabela 4.8). 
Tabela 4.7. Posicionamento e localização dos tRNAs ao longo do cromossomo, nas quatro linhagens de Xf. Sublinhado, destaque para colinearidade de posicionamento de tRNA entre as linhagens. Dentro dos parênteses está indicado a qual profago está associado o tRNA.

\begin{tabular}{|c|c|c|c|c|c|c|c|}
\hline \multicolumn{2}{|c|}{ Xf-CVC } & \multicolumn{2}{|c|}{ Xf-PD } & \multicolumn{2}{|c|}{ Xf-OL } & \multicolumn{2}{|c|}{ Xf-AL } \\
\hline Posição & tRNA & Posição & tRNA & Posição & tRNA & Posição & tRNA \\
\hline$\underline{20945}$ & MET & $\underline{20804}$ & MET & $\underline{20651}$ & MET & $\underline{20801}$ & MET \\
\hline$\overline{62407}$ & $\overline{\mathrm{ARG}}$ & $\overline{61898}$ & $\overline{\mathrm{ARG}}$ & $\overline{61749}$ & $\overline{\overline{\text { ARG }}}$ & $\overline{61948}$ & $\overline{\mathrm{ARG}}$ \\
\hline$\overline{68209}$ & $\overline{\underline{\mathbf{A L A}}}$ & $\overline{67692}$ & $\overline{\overline{\mathbf{A L A}}}$ & $\overline{67549}$ & $\overline{\mathbf{A L A}}$ & $\overline{66910}$ & $\underline{\overline{\mathbf{A L A}}}$ \\
\hline$\overline{68298}$ & ILE & $\overline{67781}$ & $\underline{\text { ILE }}$ & $\overline{67638}$ & $\underline{\underline{\text { ILE }}}$ & $\overline{66999}$ & $\underline{\underline{\text { ILE }}}$ \\
\hline$\overline{123996}$ & $\overline{\text { SER }}$ & $\overline{122451}$ & $\overline{\overline{\text { SER }}}$ & $\overline{122219}$ & $\overline{\text { SER }}$ & $\overline{121291}$ & $\overline{\overline{\text { SER }}}$ \\
\hline$\overline{173925}$ & $\overline{\overline{\mathrm{ALA}}}$ & $\overline{172775}$ & $\overline{\overline{\mathrm{ALA}}}$ & $\overline{172428}$ & $\overline{\overline{\mathbf{A L A}}}$ & $\overline{170171}$ & $\overline{\overline{\mathbf{A L A}}}$ \\
\hline$\overline{174014}$ & $\overline{\text { ILE }}$ & $\overline{172864}$ & $\overline{\text { ILE }}$ & $\overline{\mathbf{1 7 2 5 1 7}}$ & $\overline{\underline{\text { ILE }}}$ & $\overline{170260}$ & $\overline{\underline{\text { ILE }}}$ \\
\hline 224513 & $\overline{\overline{\mathbf{A L A}}}$ & 223245 & $\overline{\overline{\mathbf{A L A}}}$ & 222935 & $\overline{\overline{\mathbf{A L A}}}$ & 312212 & THR \\
\hline 236114 & GLU & 234838 & GLU & 234532 & GLU & 608086 & CYS (xap2) \\
\hline$\overline{242842}$ & $\overline{\text { MET }}$ & $\overline{241438}$ & $\overline{\text { MET }}$ & $\overline{241133}$ & $\overline{\text { MET }}$ & 791760 & LYS \\
\hline$\overline{\mathbf{3 0 8 6 4 3}}$ & $\overline{\text { PHE }}$ & $\overline{\mathbf{3 0 7 0 7 8}}$ & $\overline{\text { PHE }}$ & $\overline{\mathbf{3 0 4 9 7 8}}$ & $\overline{\text { PHE }}$ & 841324 & GLY (xap3) \\
\hline$\underline{\mathbf{3 1 9 0 5 8}}$ & LEU & $\underline{\mathbf{3 1 7 4 9 7}}$ & LEU & $\underline{\mathbf{3 1 5 3 1 3}}$ & LEU & 895835 & LEU \\
\hline$\overline{405834}$ & $\overline{\text { GLN }}$ & $\overline{431266}$ & $\overline{\overline{\mathbf{L E U}}}$ & $\overline{426988}$ & $\overline{\mathbf{L E U}}$ & 945109 & LEU \\
\hline 405956 & MET & 431472 & $\underline{\text { GLU }}$ & 427194 & GLU & 949607 & LEU \\
\hline 486925 & ASN (xfp6) & $\overline{431601}$ & $\overline{\overline{\mathbf{A L A}}}$ & $\overline{\mathbf{4 2 7 3 2 3}}$ & $\overline{\overline{\mathrm{ALA}}}$ & 956628 & VAL \\
\hline 615973 & SER (cvc-r1) & $\overline{506276}$ & $\overline{\overline{\mathbf{L E U}}}$ & $\overline{\mathbf{5 0 4 9 5 7}}$ & $\overline{\overline{\mathbf{L E U}}}$ & 956733 & ASP \\
\hline 649104 & VAL (xfp1) & $\overline{558377}$ & $\overline{\mathbf{L E U}}$ & $\overline{557091}$ & $\overline{\overline{\mathbf{L E U}}}$ & 1001263 & LYS \\
\hline 699322 & $\mathrm{PRO}$ & $\overline{562897}$ & $\overline{\overline{\mathbf{L E U}}}$ & $\overline{561529}$ & $\overline{\overline{\mathbf{L E U}}}$ & 1100709 & GLN \\
\hline 732147 & GLY & $\overline{569915}$ & $\underline{\overline{\text { VAL }}}$ & 568555 & $\overline{\mathrm{VAL}}$ & 1100831 & MET \\
\hline 816600 & PRO & $\overline{570020}$ & $\overline{\overline{\mathbf{A S P}}}$ & $\overline{568660}$ & $\overline{\mathbf{A S P}}$ & 1183416 & ASN \\
\hline 926649 & VAL (cvc-r2) & 617940 & $\underline{\mathrm{LYS}}$ & $\underline{616776}$ & $\underline{\mathrm{LYS}}$ & 1270322 & SER (al-r3) \\
\hline 1017939 & LEU & $\overline{953053}$ & CYS (pd-r1) & $\overline{1066185}$ & $\overline{\text { SER }}$ & 1300637 & VAL (xap5) \\
\hline 1018144 & GLU & 1142638 & LYS (xpd5) & 1182074 & ASN (xop5) & 1356509 & ALA \\
\hline 1018273 & ALA & 1263216 & SER & 1265419 & MET & 1367961 & GLU \\
\hline 1078913 & LEU & 1275932 & THR & 1265541 & GLN & 1374562 & MET \\
\hline 1131319 & LEU & 1279860 & GLY & 1312754 & LYS (xop6) & 1438507 & PHE \\
\hline 1135824 & LEU & 1287175 & ARG & 1375248 & SER & 1448935 & LEU \\
\hline 1142842 & VAL & 1417317 & SER & 1387601 & THR (xop7) & 1560543 & LEU \\
\hline 1142947 & ASP & 1556021 & GLY (xpd6) & 1391175 & GLY & 1560749 & GLU \\
\hline 1191317 & LYS & 1670178 & THR & 1398491 & $\mathrm{ARG}$ & 1560878 & ALA \\
\hline 1631333 & ARG (xfp4) & 1738264 & VAL (pd-r2) & 1611318 & CYS (ol-r1) & 1667714 & SER \\
\hline 1638644 & GLY (giCVC) & 1772646 & SER & 1710064 & GLY (xop10) & 1679779 & THR \\
\hline 1707587 & THR & 1861069 & ASN (xpd8) & 1824409 & THR & 1682092 & GLY (al-r1) \\
\hline 1720323 & SER & 1944465 & MET & 1892668 & VAL & 1689410 & ARG \\
\hline 1776435 & LYS (cve-r5) & 1944587 & GLN & 1925076 & $\underline{\text { SER }}$ & $\underline{1785293}$ & $\underline{\text { SER }}$ \\
\hline 2004768 & CYS (xfp5) & 2020502 & $\underline{\text { VAL }}(\operatorname{xpd} 7)$ & $\overline{2125513}$ & VAL (xop9) & $\overline{2129565}$ & VAL (xap9) \\
\hline 2047100 & SER & $\overline{2124945}$ & PRO & $\overline{2228589}$ & PRO & 2231012 & PRO \\
\hline 2194005 & GLY (cvc-r4) & $\overline{2210084}$ & $\overline{\text { GLY }}$ & $\overline{2313708}$ & $\overline{\text { GLY }}$ & $\overline{2315998}$ & $\overline{\text { GLY }}$ \\
\hline 2295229 & THR & $\overline{2239563}$ & $\overline{\text { PRO }}$ & $\overline{2343096}$ & $\overline{\overline{\text { PRO }}}$ & $\overline{2345319}$ & $\overline{\overline{\text { PRO }}}$ \\
\hline 2459885 & ARG & 2303865 & ARG & 2407447 & ARG & 2410837 & ARG \\
\hline 2524190 & TRP & 2368495 & TRP & 2472238 & TRP & 2475639 & TRP \\
\hline$\overline{2525616}$ & $\overline{\text { THR }}$ & $\overline{2369922}$ & $\overline{\text { THR }}$ & $\overline{2473665}$ & $\overline{\overline{\text { THR }}}$ & $\overline{2477066}$ & $\overline{\overline{\text { THR }}}$ \\
\hline$\underline{2525732}$ & GLY & $\underline{2370038}$ & GLY & 2473781 & $\overline{\text { GLY }}$ & $\underline{2477182}$ & GLY \\
\hline 2525851 & TYR & $\underline{2370157}$ & TYR & 2473900 & TYR & $\underline{2477301}$ & TYR \\
\hline 2529679 & GLN & $\underline{2373982}$ & GLN & $\underline{2477726}$ & GLN & $\underline{2481127}$ & GLN \\
\hline$\underline{2652606}$ & PRO & $\underline{2489453}$ & PRO & 2590521 & PRO & $\underline{2604333}$ & PRO \\
\hline$\overline{2652744}$ & $\overline{\overline{\mathrm{ARG}}}$ & $\overline{2489593}$ & $\overline{\overline{\mathrm{ARG}}}$ & $\overline{2590661}$ & $\overline{\overline{\mathrm{ARG}}}$ & $\overline{2604472}$ & $\overline{\overline{\mathrm{ARG}}}$ \\
\hline$\overline{2652862}$ & $\overline{\underline{\text { HIS }}}$ & $\overline{2489711}$ & $\overline{\underline{\text { HIS }}}$ & $\overline{2590779}$ & $\underline{\underline{\text { HIS }}}$ & $\overline{2604590}$ & $\overline{\underline{\text { HIS }}}$ \\
\hline$\overline{2653049}$ & LYS (cve-r3) & $\overline{2489898}$ & $\overline{\mathrm{LYS}}$ & $\overline{2590966}$ & $\overline{\underline{\mathrm{LYS}}}$ & 2604777 & LYS (xap11) \\
\hline
\end{tabular}


Tabela 4.8. tRNAs nas quatros linhagens de Xf e sua correlação como sítio de inserção para regiões de profagos e IGs (a associação contabiliza os tRNAs completos e fragmentos).

\begin{tabular}{l|c|c}
\hline \multicolumn{1}{c|}{ tRNA } & Quantidade & Associado a elementos em: \\
\hline Arginina (ARG) & 4 & Xf-CVC \\
Alanina (ALA) & 4 & - \\
Asparagina (ASN) & 1 & Xf-CVC / Xf-PD / Xf-OL / Xf-AL \\
Ácido Aspártico (ASP) & 1 & - \\
Cisteína (CYS) & 1 & Xf-CVC / Xf-PD / Xf-OL / Xf-AL \\
Glutamina (GLN) & 2 & - \\
Ácido Glutâmico (GLU) & 2 & - \\
Glicina (GLY) & 4 & Xf-CVC / Xf-PD / Xf-OL / Xf-AL \\
Histidina (HIS) & 1 & - \\
Isoleucina (ILE) & 2 & - \\
Leucina (LEU) & 5 & - \\
Lisina (LYS) & 3 & Xf-CVC / Xf-PD / Xf-OL / Xf-AL \\
Metionina (MET) & 3 & Xf-CVC / Xf-AL \\
Fenilalanina (PHE) & 1 & Xf-PD / Xf-OL \\
Prolina (PRO) & 3 & - \\
Serina (SER) & 4 & - \\
Treonina (THR) & 3 & Xf-CVC / Xf-PD / Xf-OL / Xf-AL \\
Triptofano (TRP) & 1 & 1 \\
Tirosina (TYR) & 3 & \\
Valina (VAL) & &
\end{tabular}

Em relação à ocorrência dos tRNAs como sítios preferências de inserção, há várias possibilidades de ocorrência (ilustradas na figura 4.19): (A) tRNAs estão localizados ao lado de integrases que representam a borda de determinada região relacionada a profago, sendo que em dois casos um fragmento do respectivo tRNA é encontrado na outra borda, indicando a ocorrência da inserção com reconstituição do tRNA; (B) tRNAs estão localizados na borda de regiões de profagos, sendo sua respectiva integrase localizada na outra borda; (C) tRNAs estão localizados na borda de regiões de profagos que não apresentam integrases em sua constituição; (D) Fragmentos de tRNAs estão localizados na borda de regiões de profagos que podem ou não conter integrases completas ou fragmentos, e (E) Regiões de profagos carregam tRNAs internamente, não sendo utilizados como sítios de inserção, porém são indicativos de serem adquiridos pela bactéria por mecanismos de TGL. A tabela 4.9 aponta a qual tRNA as regiões de profagos e ilhas estão associadas conforme as formas de ocorrência apresentadas. 

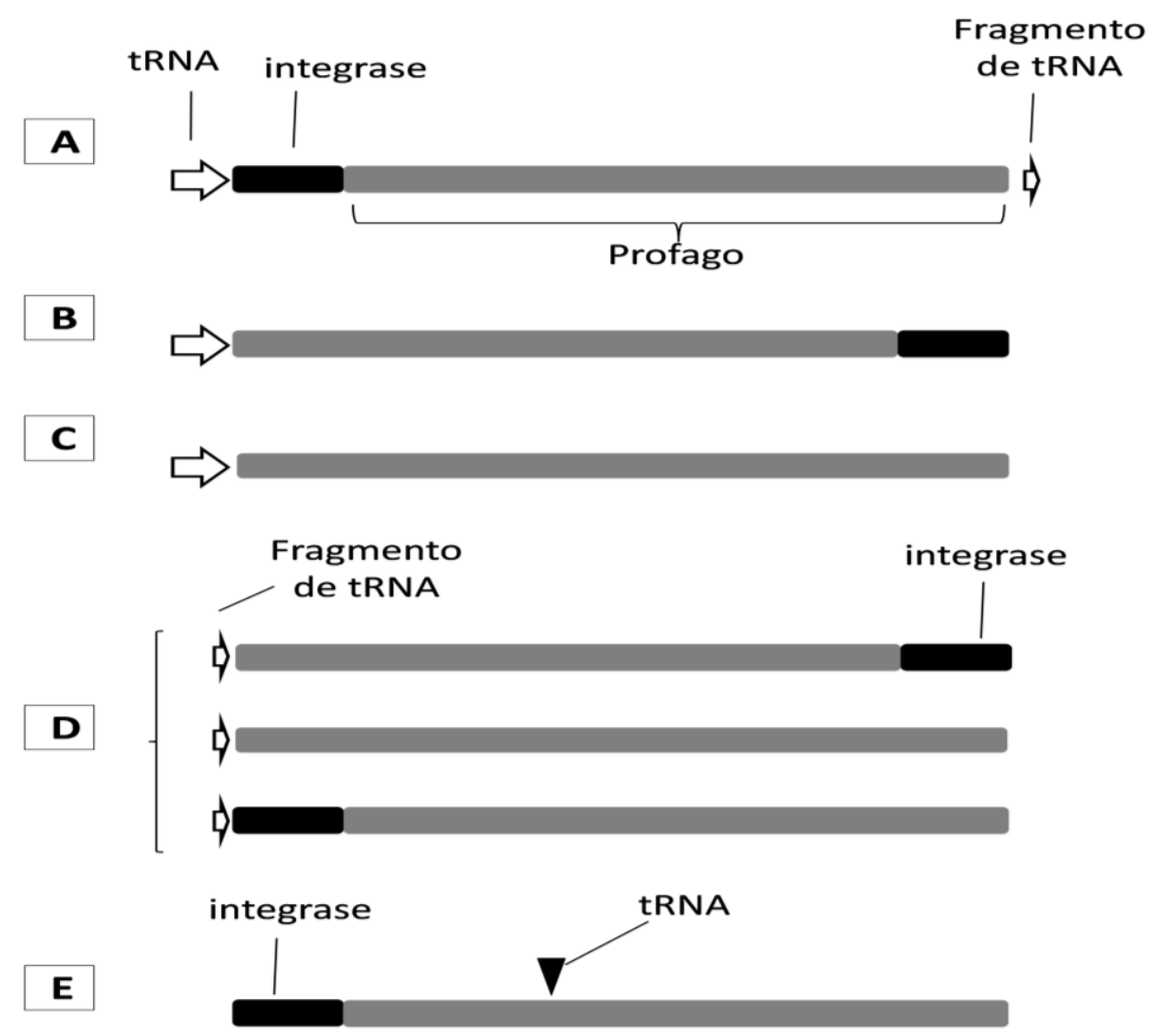

Figura 4.19. Formas de ocorrência dos tRNAs no genoma de Xf, quando associados a IGs e regiões de profagos. As integrases representadas podem ser completas, com FS /SCF ou fragmentos. No tipo A, apenas em duas ocorrências aparecem fragmentos de tRNA na outra ponta. O tipo E indica que a região relacionada a profago contém um tRNA interno.

Tabela 4.9. Associação dos tRNAs com regiões de profagos e IGs *

\begin{tabular}{|c|c|c|c|c|c|c|c|}
\hline \multicolumn{2}{|c|}{ Xf-CVC } & \multicolumn{2}{|c|}{ Xf-PD } & \multicolumn{2}{|c|}{ Xf-OL } & \multicolumn{2}{|c|}{ Xf-AL } \\
\hline Profago / IG & tRNA & Profago & tRNA & Profago & tRNA & Profago & tRNA \\
\hline xfp1 & VAL $\left({ }^{A}\right)$ & xpd1 & - & xop1 & - & xap1 & frag- VAL $\left({ }^{\mathrm{D}}\right)$ \\
\hline $\mathrm{xfp} 2$ & frag -VAL $\left({ }^{\mathrm{D}}\right)$ & $\mathrm{xpd} 2$ & - & xop2 & - & xар2 & CYS $\left({ }^{\mathrm{B}}\right)$ \\
\hline xfp3 & - & xpd3 & - & xop3 & - & xap3 & $\operatorname{GLY}\left({ }^{\mathrm{E}}\right)$ \\
\hline xfp4 & $\operatorname{ARG}\left({ }^{\mathrm{B}}\right)$ & xpd4 & - & xop4 & - & xap4 & frag $-\operatorname{ASN}\left({ }^{D}\right)$ \\
\hline xfp5 & CYS $\left({ }^{\mathrm{B}}\right)$ & xpd5 & $\operatorname{LYS}\left({ }^{\mathrm{C}}\right)$ & xop5 & $\operatorname{ASN}\left({ }^{\mathrm{A}}\right)$ & xap5 & $\operatorname{VAL}\left({ }^{\mathrm{B}}\right)$ \\
\hline xfp6 & $\operatorname{ASN}\left({ }^{A-f}\right)$ & xpd6 & $\operatorname{GLY}\left({ }^{\mathrm{E}}\right)$ & xop6 & $\operatorname{LYS}\left({ }^{\mathrm{A}}\right)$ & xap6 & - \\
\hline giCVC & GLY $\left({ }^{A}\right)$ & xpd7 & $\operatorname{VAL}\left({ }^{\mathrm{A}}\right)$ & xop7 & $\operatorname{THR}\left({ }^{\mathrm{A}}\right)$ & xap7 & - \\
\hline cvc-r-1 & $\operatorname{SER}\left({ }^{B}\right)$ & xpd8 & $\operatorname{ASN}\left({ }^{B}\right)$ & xop8 & - & xap8 & - \\
\hline cvc-r-2 & $\operatorname{VAL}\left({ }^{\mathrm{A}}\right)$ & pd-r-1 & $\operatorname{CYS}\left({ }^{\mathrm{B}}\right)$ & xop9 & $\operatorname{VAL}\left({ }^{\mathrm{A}}\right)$ & xap9 & $\operatorname{VAL}\left({ }^{\mathrm{A}-\mathrm{f}}\right)$ \\
\hline cvc-r-3 & $\operatorname{LYS}\left({ }^{\mathrm{A}}\right)$ & pd-r-2 & $\operatorname{VAL}\left({ }^{\mathrm{A}}\right)$ & xop10 & $\operatorname{GLY}\left({ }^{\mathrm{E}}\right)$ & xap10 & frag - LYS $\left({ }^{D}\right)$ \\
\hline cvc-r-4 & GLY $\left({ }^{\mathrm{E}}\right)$ & & & ol-r-1 & $\operatorname{CYS}\left({ }^{\mathrm{B}}\right)$ & xap11 & $\operatorname{LYS}\left({ }^{\mathrm{A}}\right)$ \\
\hline cvc-r-5 & $\operatorname{LYS}\left({ }^{\mathrm{C}}\right)$ & & & & & al-r-1 & $\operatorname{GLY}\left({ }^{\mathrm{A}}\right)$ \\
\hline & & & & & & al-r-2 & $\mathrm{P}$ \\
\hline & & & & & & al-r-3 & $\operatorname{SER}\left({ }^{\mathrm{B}}\right)$ \\
\hline
\end{tabular}

* Classificação referente à figura 4.18. A-f se refere à ocorrência do tipo A, mas com um fragmento de tRNA na borda oposta. Fragmentos de tRNA estão representados pela expressão "frag". 
Vinte e nove $(62 \%)$ das quarenta e sete regiões de profagos e IGs identificadas nas quatro linhagens apresentam associação com tRNAs, sendo que mais quatro $(8,5 \%)$ regiões estão associadas a fragmentos de tRNAs. No total, oito tipos de tRNAs estão envolvidos: VAL[9], GLY[6], LYS[6], CYS[4], ASN[4], SER[2], THR[1] e ARG[1].

Os resultados apontam que a ocorrência do tipo A é a mais freqüente: ocorre em todas as linhagens, estando presente 14 vezes (representa 41,17\%) e está associada a cinco tipos de tRNA (VAL[6], LYS[3], GLY[2], ASN[2] e THR[1]). Em apenas duas ocasiões há a identificação de fragmentos de tRNA na outra borda da região relacionada a profago (xfp6 [ASN] e xap9 [VAL]) (Figura 4.20), sendo que estes fragmentos apresentam pelo menos 50\% do tamanho do tRNA original (presente na outra borda) e ao lado da integrase, indicando que a hipótese de inserção com reconstituição do tRNA neste caso é válida (Williams et al., 2002).
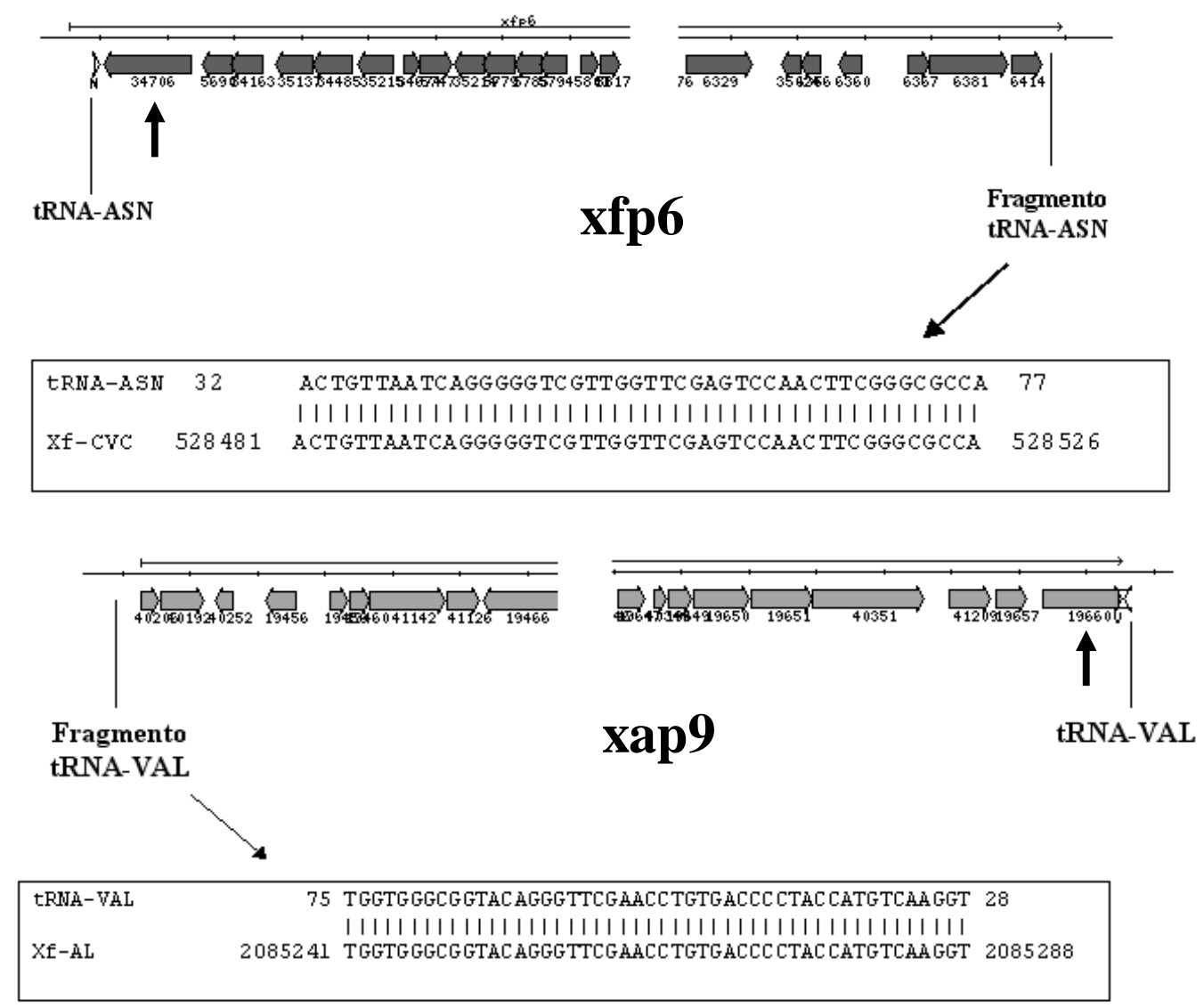

Figura 4.20. Esquema de tRNA associado aos elementos xfp6 e xap9 no genoma de Xf-CVC e Xf-AL, respectivamente. Ao lado de cada tRNA, há uma integrase (indicada pela seta). No detalhe, alinhamento dos fragmentos de tRNA (identificados na borda oposta) com o tRNA inteiro.

A ocorrência do tipo B está presente 9 vezes (representa 26,47\%): ocorre em todas as linhagens, e está associada a cinco tipos de tRNA (CYS[4], SER[2], VAL[1], ARG[1] e 
ASN[1]); o tRNA-CYS é exclusivo para esta forma de ocorrência de inserção no universo destas quatro linhagens. A ocorrência do tipo $\mathbf{C}$ está presente apenas duas vezes (5,88\%), uma em XfCVC e uma em Xf-PD, associada exclusivamente ao tRNA-LYS. A ocorrência do tipo D está presente quatro vezes $(11,76 \%)$ e ocorre apenas em Xf-CVC e Xf-AL, associada a três tRNAs (VAL[2], ASN[1] e LYS[1]); nesta ocorrência, apenas fragmentos de tRNAs estão associados a regiões de profagos, conforme pode ser visualizado na figura 4.21.

Por último, a ocorrência do tipo $\mathbf{E}$ está presente nas quatro linhagens e é exclusiva das regiões de profagos que carregam o tRNA-GLY em sua constituição(regiões cvc-r4, xpd6, xop10 e xap3). Os resultados apontam que, apesar do tRNA-GLY não estar associado diretamente como sítio de inserção, aparenta ser parte constituinte do fago, indicando que pode ter sido adquirido por um mecanismo de transdução. Em Xf-CVC, uma cópia do tRNA-Gly está associada como sítio de inserção para aquisição da ilha giCVC e sua outra cópia (que a priori seria a cópia relacionada com xpd6, xop10 e xap3, no mesmo contexto genômico) está localizada na região remanescente cvc-r4. Essa região não foi classificada como região relacionada a profagos por não cumprir todos os critérios estabelecidos de identificação, mas aparentemente trata-se de uma região degenerada ou um resquício de integração (Figura 4.22). Este resultado demonstra que o tRNA-GLY presente nestes elementos pode ter sido transferido horizontalmente para Xylella.

Em relação à análise da frequiência dos tRNAs e sua associação com fagos e IGs, os tRNAs CYS e ASN apresentam cópia única no genoma, indicando ser uma região essencial para a bactéria; no entanto, são também sítios de inserção para as regiões: xfp5, pd-r1, ol-r1, xap2 (tRNA-CYS) e xpd8, xop5, xfp6 (tRNA-ASN), respectivamente. Analisando minuciosamente estas regiões, constata-se que, com exceção de xfp6, todas as demais não apresentam conjunto de genes necessários para caracterizarem-se como profagos temperados, ou seja, capazes de ativar seu ciclo lítico. Uma hipótese que pode ser levantada é que, por serem tRNAs essenciais para a bactéria (por estarem em cópia única), seria interessante para a bactéria manter os profagos associados incapazes de acionar o ciclo lítico nesta região, desta forma protegendo esse sítio da invasão por outros fagos temperados, que eventualmente poderiam usar essas regiões com consequiências deletérias para a bactéria, caso a inserção ocasionasse quebra sem reconstituição deste tRNA (conforme observado no exemplo de forma de ocorrência $\mathbf{D}$ ). 

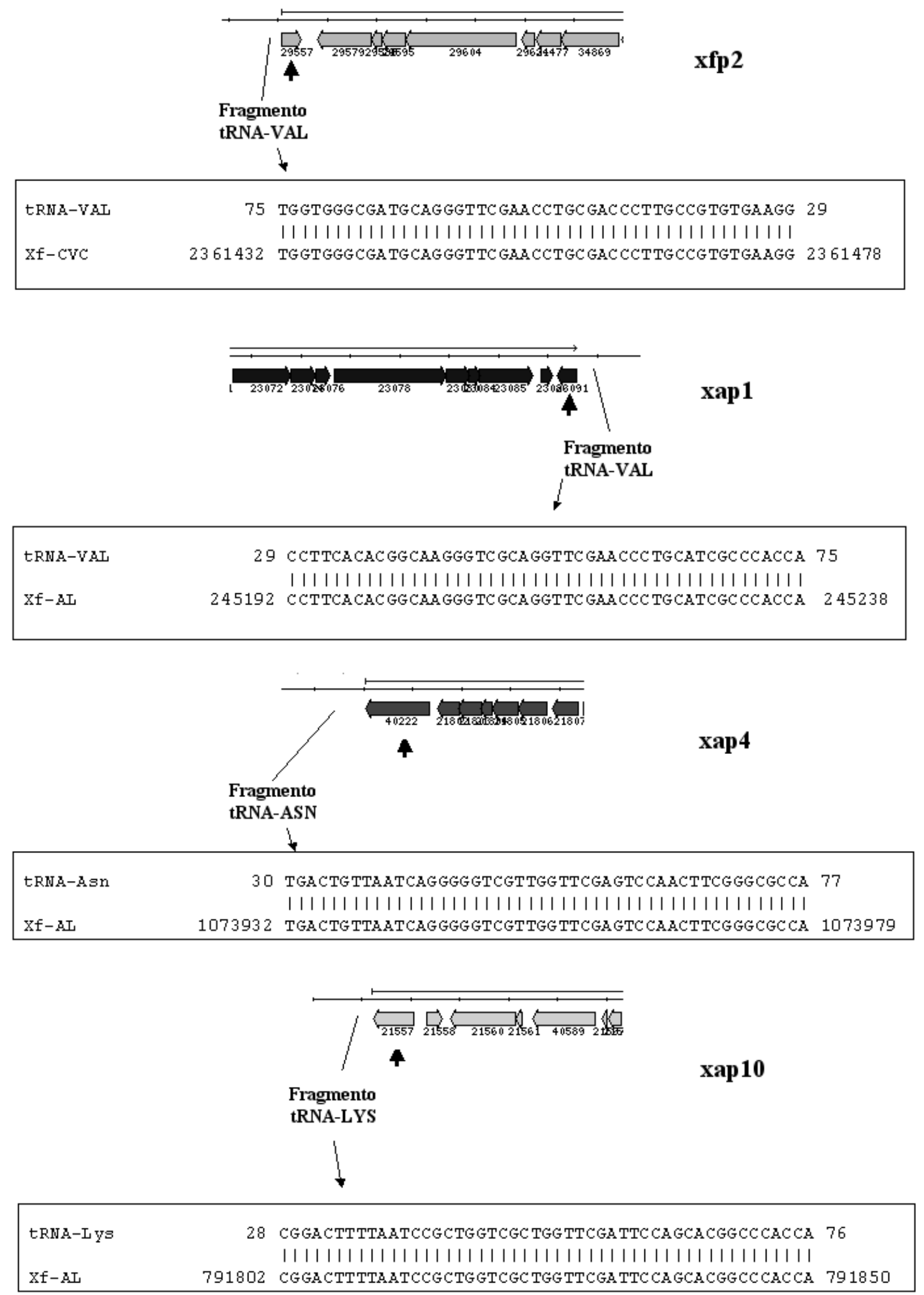

Figura 4.21. Esquema das ocorrências do tipo D. A figura ilustra apenas a borda dos elementos xfp2, xap1, xap4 e xap10 que contêm integrases associadas a fragmentos de tRNAs. As integrases estão indicadas pelas setas (apenas a integrase xap4 é completa, as demais são fragmentos). No detalhe, alinhamento dos fragmentos de tRNA com o tRNA inteiro. 
Dois exemplos merecem ser analisados com relação a esta hipótese: a região xfp6, que se inseriu e reconstituiu um tRNA-ASN, e xap4, associado a um fragmento de tRNA-ASN (indicando uma possível quebra desse tRNA durante a inserção do fago, em algum momento da história evolutiva de Xf-AL; no entanto, apresenta outra cópia de tRNA-ASN, aproximadamente $110 \mathrm{~kb}$ distantes).

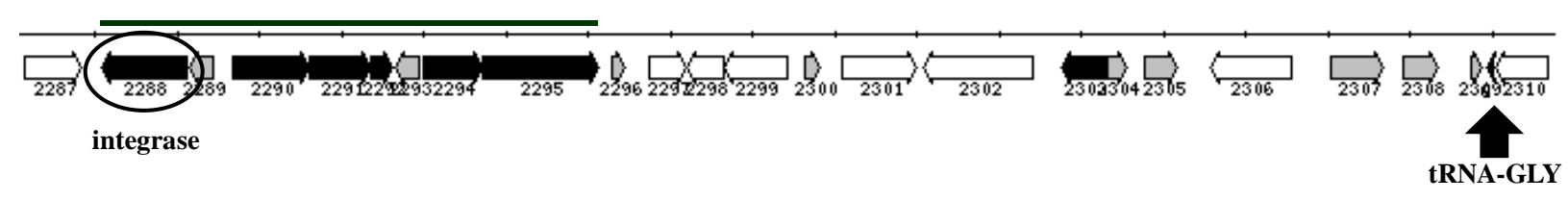

Figura 4.22. Região onde está localizado o tRNA-GLY de Xf-CVC (cvc-r4). As ORFs estão representadas em forma de setas, respeitando categorização funcional: PRETO: Genes relacionados a fagos; CINZA: Hipotética; BRANCO: metabolismo em geral. A seta na cor preta informa a posição do tRNA-GLY; o traço em preto indica a predição do programa prophageFinder $(\sim 6,5 \mathrm{~kb}$, fora dos critérios de inclusão de região relacionada a profagos, porém classificada como resquício).

E, por último, doze regiões não estão associadas a tRNAs $(x f p 3, x p d 2, x p d 3, x p d 4$, xор1, хор2, хор3, хор4, хор8, хар6, хар7, хар8 e al-r2), sendo que xfp3 e al-r2 apresentam integrases em FS/SCF e xop1 e xap8 não apresentam integrases; as demais regiões apresentam integrases completas com domínio catalítico tirosina recombinase.

Estes resultados demonstram que aproximadamente $71 \%$ das regiões relacionadas a profagos e IGs identificadas nas quatro linhagens apresentam associação com tRNA como sítio de inserção. De modo interessante, as regiões relacionadas aos profagos maiores (em pb) e que apresentam o conjunto de ORFs essenciais (porção não-estrutural e estrutural) estão associadas a tRNAs com maior número de cópias no cromossomo, indicando um possível mecanismo preferencial de inserção nestas regiões. 


\subsection{REARRANJOS GENÔMICOS E MAPA GENÔMICO COMPARATIVO ENTRE AS QUATRO LINHAGENS}

Rearranjos e deleções genômicas em larga escala são considerados eventos importantes na evolução de genomas bacterianos. No passado, estas mudanças em larga escala eram estudadas por técnicas citogenéticas, mas atualmente é possível estudar estes eventos por técnicas de genômica comparativa (Eisen, 2000). A análise dos rearranjos e deleções entre os genomas de cada linhagem foi realizada pelo programa MUMmer (Figura 4.23); os alinhamentos foram realizados a partir da origem de replicação. Posteriormente, com a identificação das regiões de profagos nas quatro linhagens e com o uso do programa M-GCAT, foi possível analisar a sintenia, entre as quatro Xylellas, associada com o posicionamento das regiões de profagos e ilhas (Figura 4.24). Esta figura ilustra o alinhamento global entre os genomas das quatro linhagens, indicando as regiões que apresentam sintenia e a localização de cada região relacionada a profago e IG.

Quando comparados entre si, os genomas das 4 linhagens de Xf apresentam grande conservação de seqüência, e a colinearidade é quebrada principalmente pela presença de fagos e integrases. A comparação genômica entre as quatro linhagens de Xf revela a presença de até 16 blocos conservados, cujas bordas delimitam as regiões de quebras de colinearidade (Figura 4.24, representado pelas letras $\mathrm{A}-\mathrm{M})$.

A molécula candidata de Xf-AL aparece como a linhagem que apresenta maior número de regiões de quebra de colinearidade, quando comparada às outras três linhagens (16 quebras no total), seguida por Xf-CVC com 14 quebras e por Xf-PD e Xf-OL com 13 quebras. Além de XfAL apresentar maior número de quebras, também é a linhagem que apresenta maior quantidade de regiões de profagos distribuídas de forma homogênea no genoma. Em contrapartida, as linhagens que apresentam maior colinearidade quando comparadas são Xf-OL e Xf-PD. Aparentemente, Xf-OL e Xf-PD apresentam regiões de profagos similares em tamanho, posicionamento e contexto genômico, assim como posicionamento de tRNA e número e distribuição de integrases, sugerindo que, em termos de organização genômica, a divergência entre estas linhagens tenha sido mais recente, quando comparadas às demais linhagens. 

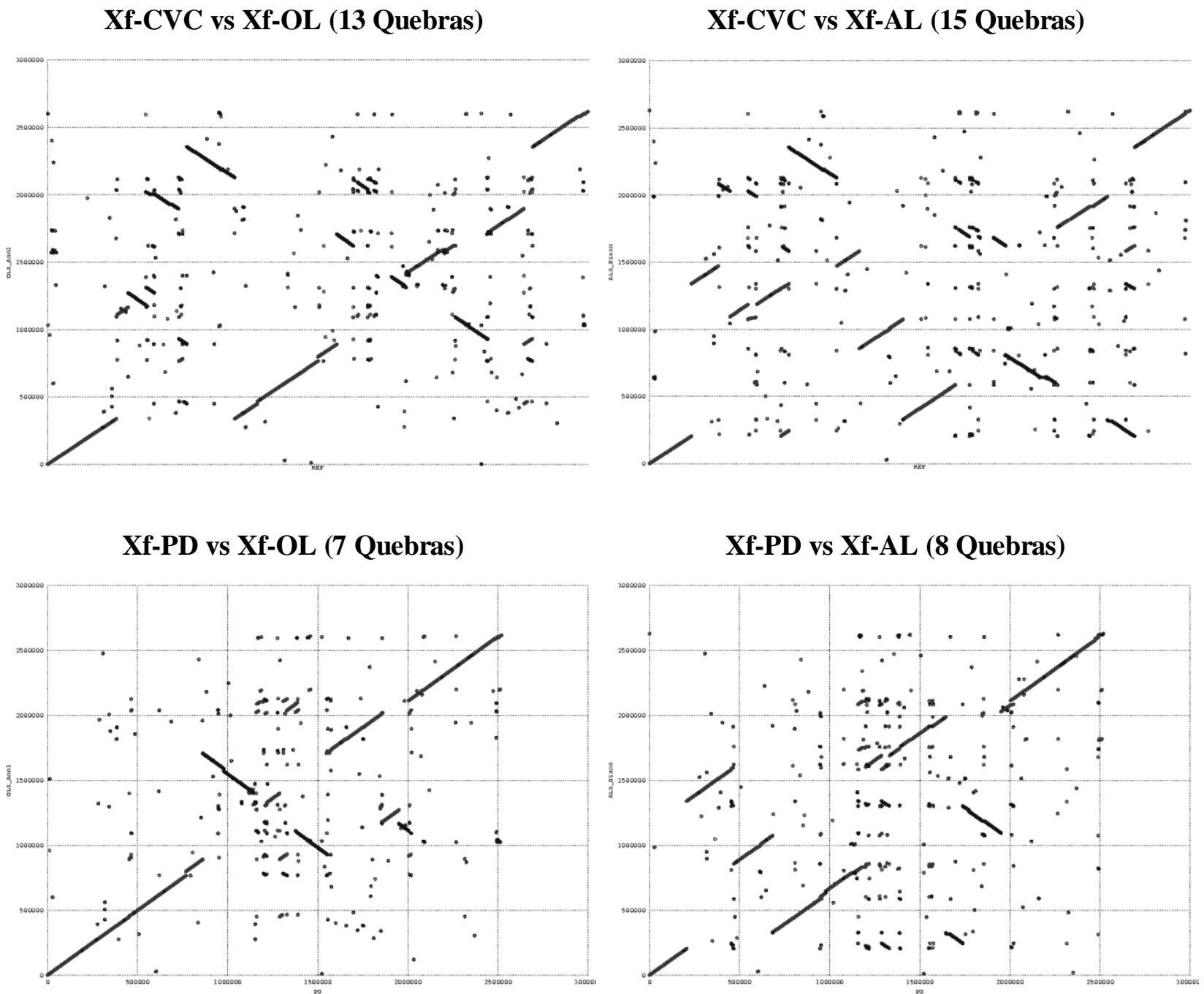

Xf-CVC vs Xf-PD (8 Quebras)

Xf-AL vs Xf-OL (15 Quebras)
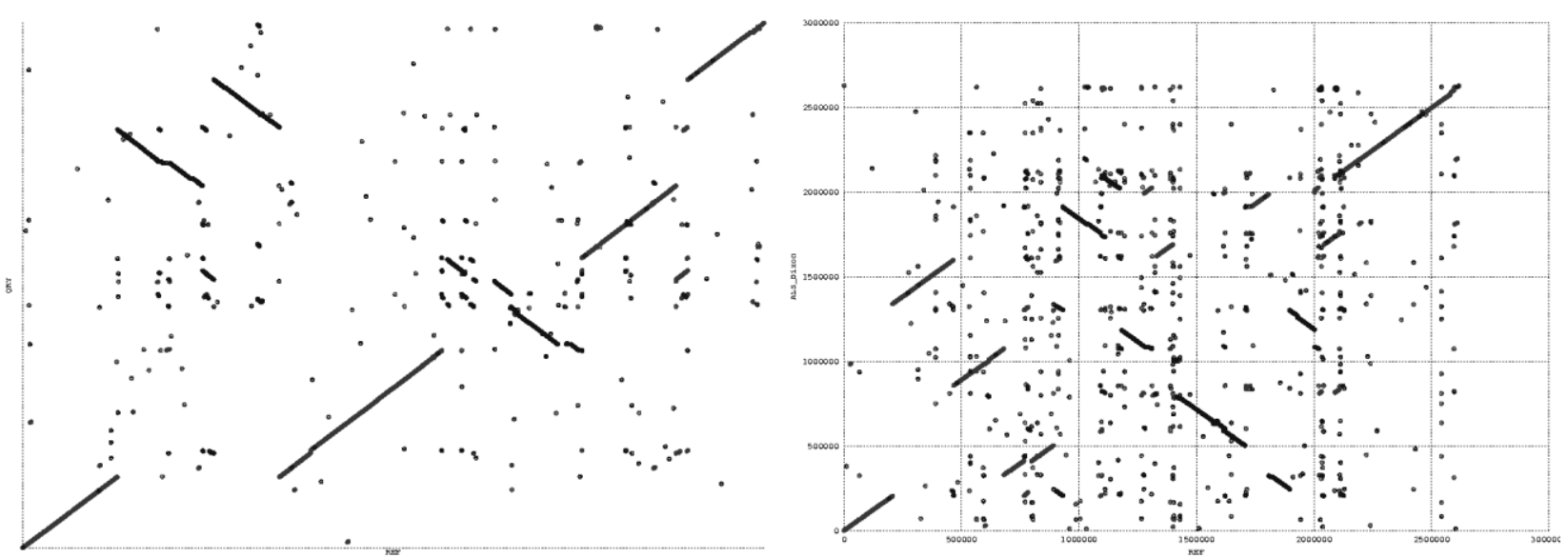

Figura 4.23. Alinhamento, em forma de Dot-plot, entre os genomas das quatro linhagens de Xf. 


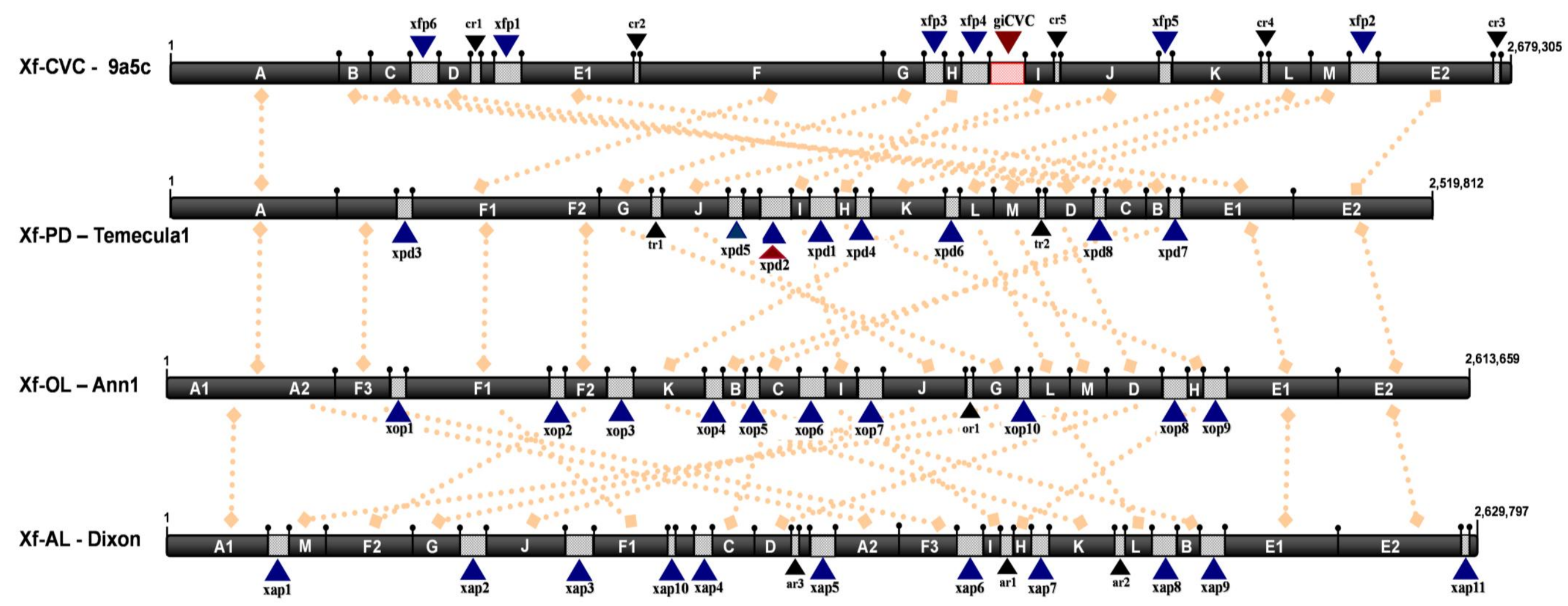

Figura 4.24. Representação comparativa entre as quatro linhagens de $X$. fastidiosa. As letras (A-M) representam regiões colineares entre as quatro linhagens, com similaridade de sequiências de nucleotídeos acima de $80 \%$ (as regiões colineares entre as linhagens também são indicadas pelos traços pontilhados). Os triângulos em azul representam a exata localização das regiões de profagos, os triângulos em vermelho representam as IGs e os triângulos menores em preto representam o posicionamento das regiões remanescentes de profagos. Figura gerada a partir dos resultados do programa M-GCAT. 
A região nas proximidades da origem de replicação (a posição "1" representa o gene dnaA e provável origem de replicação, considerando o genoma circular e seguindo orientação no sentido horário) é a única que apresenta sintenia entre as quatro linhagens (entre 2,3 Mb e 203 $\mathrm{kb}$ ). De um total de 47 regiões de profagos e IGs (incluindo as regiões remanescentes) nas quatro linhagens, 28 ( 60\%) encontram-se na região entre a base $900 \mathrm{~kb}$ até 1,6 Mb, onde está contido o término de replicação (determinado por análises de GC skew), sendo esta a região onde ocorre a maioria dos rearranjos entre as linhagens. Este resultado sugere que os fagos lisogênicos vão se integrar preferencialmente neste trecho (entre $900 \mathrm{~kb}$ e 1,6 Mb), sugerindo uma correlação entre ciclo de infecção com o tempo gasto em que o DNA encontra-se em simples fita, durante o evento de replicação, no momento da resolução da Holliday junction, assim como foi observado em outros genomas procariontes por Grigoriev (1998). Isso é um indicativo de que as regiões de profagos encontradas nesta porção do genoma podem representar recentes aquisições.

De um modo geral, os resultados apresentados nas figuras 4.23 e 4.24 evidenciam que as integrases de fagos e ilhas associadas a seus elementos (profagos e IGs) são responsáveis por todos os rearranjos genômicos identificados entre as quatro linhagens, sendo que atuam como agentes chaves no processo de evolução da organização genômica nas quatro linhagens de Xf. 


\subsection{ANÁlise DO CONTEÚdo GÊNICO PREDITO NAS REGIÕES RELACIONADAS A PROFAGOS E IGs}

Através da ferramenta de bioinformática desenvolvida para análise de genômica comparativa (phage-navigator comparative), foi possível analisar por metodologia de BBH o conteúdo das ORFs de todas as regiões de profagos e IGs identificadas nas quatro linhagens. Há 1.803 ORFs relacionadas a regiões de profagos e IGs nas quatro linhagens, sendo que 290 grupos ou clusters (1.388 ORFs) foram formados por metodologia de $\mathrm{BBH}$ (60\% de cobertura de alinhamento e e-value de 0.00001). Um total de 415 ORFs não apresenta BBHs e, por consequiência, não se agruparam em clusters, sendo que são nas IGs onde está contida a maior porcentagem de ORFs órfãs (acima de 96\% das ORFs de cada ilha não apresentam BBHs). A seguir, são apresentados os principais resultados das regiões de profagos, sendo seguidos pelos resultados das IGs.

As ORFs das regiões de profagos estão divididas em: (a) ORFs essenciais para fagos; (b) ORFs não essenciais para fagos e (c) ORFs hipotéticas e/ou hipotéticas conservadas (todas ORFs possuem uma categorização funcional definida por esse projeto; vide Materiais e Métodos). A figura 4.25A ilustra a freqüência de ORF essenciais, não-essenciais e hipotéticas/ hipotéticas conservadas para as quatro linhagens; a figura 4.25B mostra o mesmo resultado, mas considerando-se apenas as ORFs específicas de cada linhagem, ou seja, aquelas que não se agruparam em clusters de BBHs (os dados relativos às figuras 4.25A e B se encontram nas tabelas 4.10 e 4.11 , respectivamente).

A figura 4.26 ilustra a freqüência das ORFs de regiões de profagos por categorias funcionais. Mapas genômicos contendo informações sobre a anotação funcional e categorização de cada ORF podem ser visualizados no endereço eletrônico do banco de dados deste projeto (http://gracilaria.ib.usp.br/integraseDB). Estes mapas são interligados ao banco de dados de análises comparativas (phage-navigator-comparative), sendo possível realizar buscas por BBHs a partir de palavras-chaves.

De um modo geral, dentro do grupo de ORFs essenciais, foram identificadas ORFs relacionadas a proteínas não estruturais (integrases, helicases, polimerases, primases, repressores, anti-repressores e lisozimas); ORF estruturais, relacionadas com a montagem da partícula viral (placa da base, cauda, fibras da cauda e capsídeo) e, por último, ORFs relacionadas a fagos porém com função indefinida (anotadas como phage-related proteins). No grupo de ORFs não essenciais, foram identificadas as ORFs com conteúdo predito não relacionado a funções do fago, sugerindo que foram adquiridas durante o processo de transdução. 
A) Freqüência de ORFs relacionadas a fagos entre as quatro linhagens

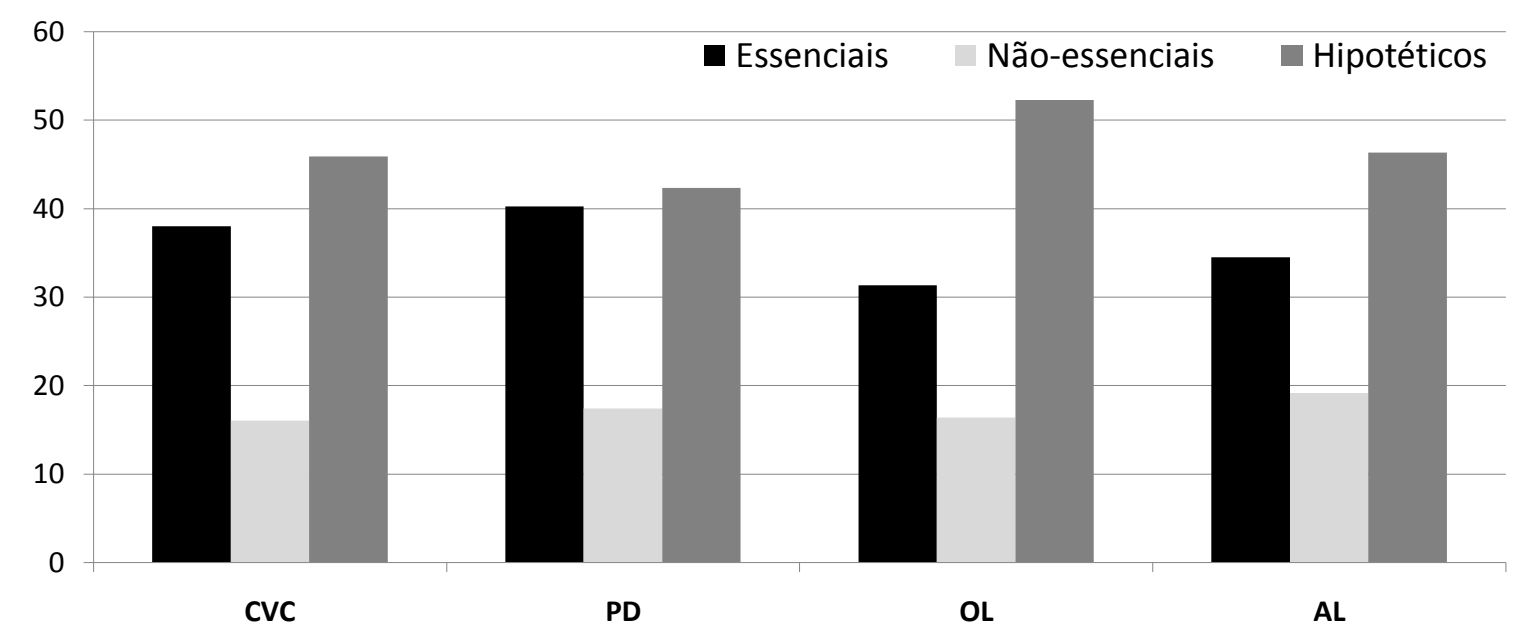

\section{B) Freqüência de ORFs específicas relacionadas a fagos entre as quatro linhagens}

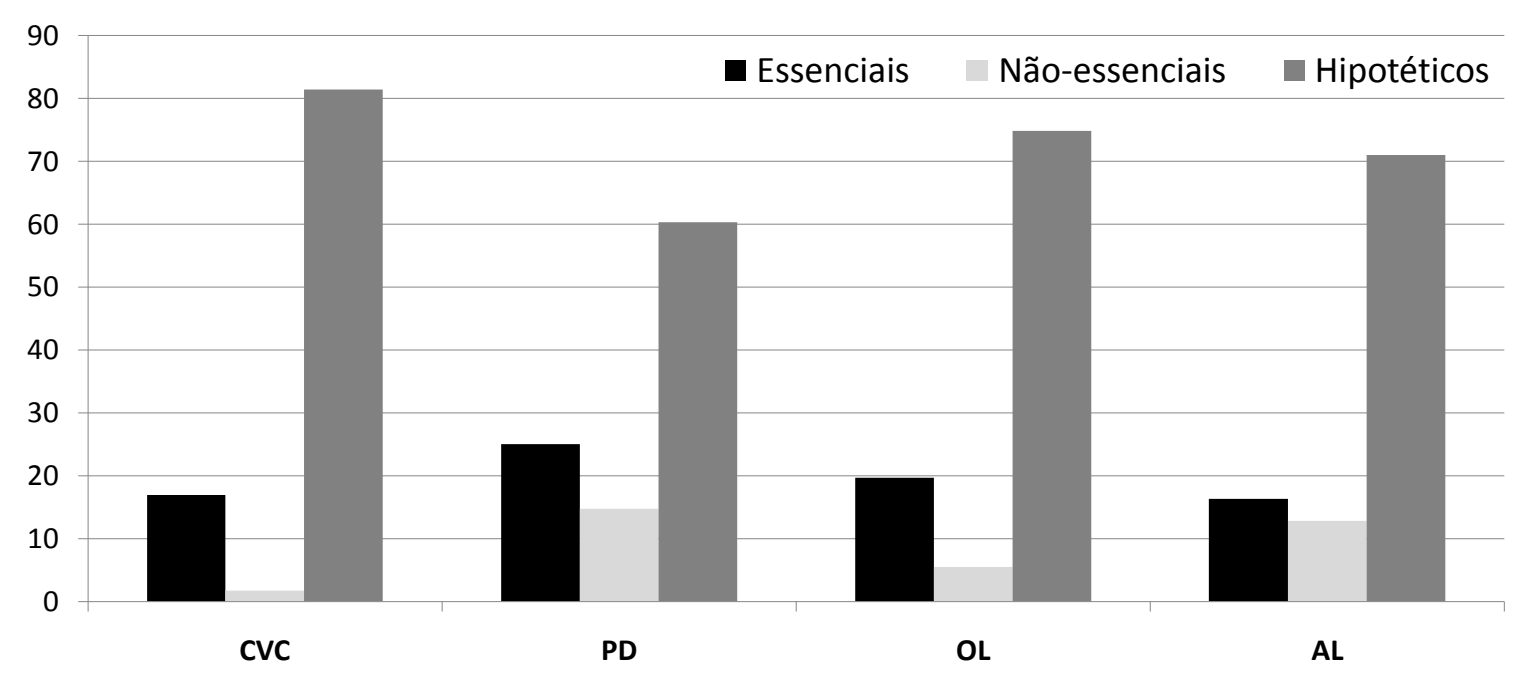

Figura 4.25. Distribuição das ORFs em regiões de profagos (ORFs essenciais, não essenciais e hipotéticas/hipotéticas conservadas). A, frequiência de ORFs relacionadas às regiões de profagos; B, freqüência das ORFs específicas. Não foram contabilizadas as ORFs de IGs.

As ORFs que compõem os 290 grupos ou clusters de BBHs são formadas na grande maioria por ORFs hipotéticas e essenciais para fagos (Figura 4.25A); no entanto, merecem destaque algumas ORFs não essenciais para fagos, com provável produto relacionado a virulência e/ou patogenicidade (freqüência de até 5\% para cada linhagem), que de certa forma poderiam estar conferindo alguma característica especial para a bactéria. Entre elas, destacam-se: (a) Phage-related PI protein (Zonular occludens toxin like protein), presente em xop7, xap10 e xpd5; e (b) virulence-associated protein E, presente em xfp5, xfp6, xpd8, xop6, xop8 e xap8. 


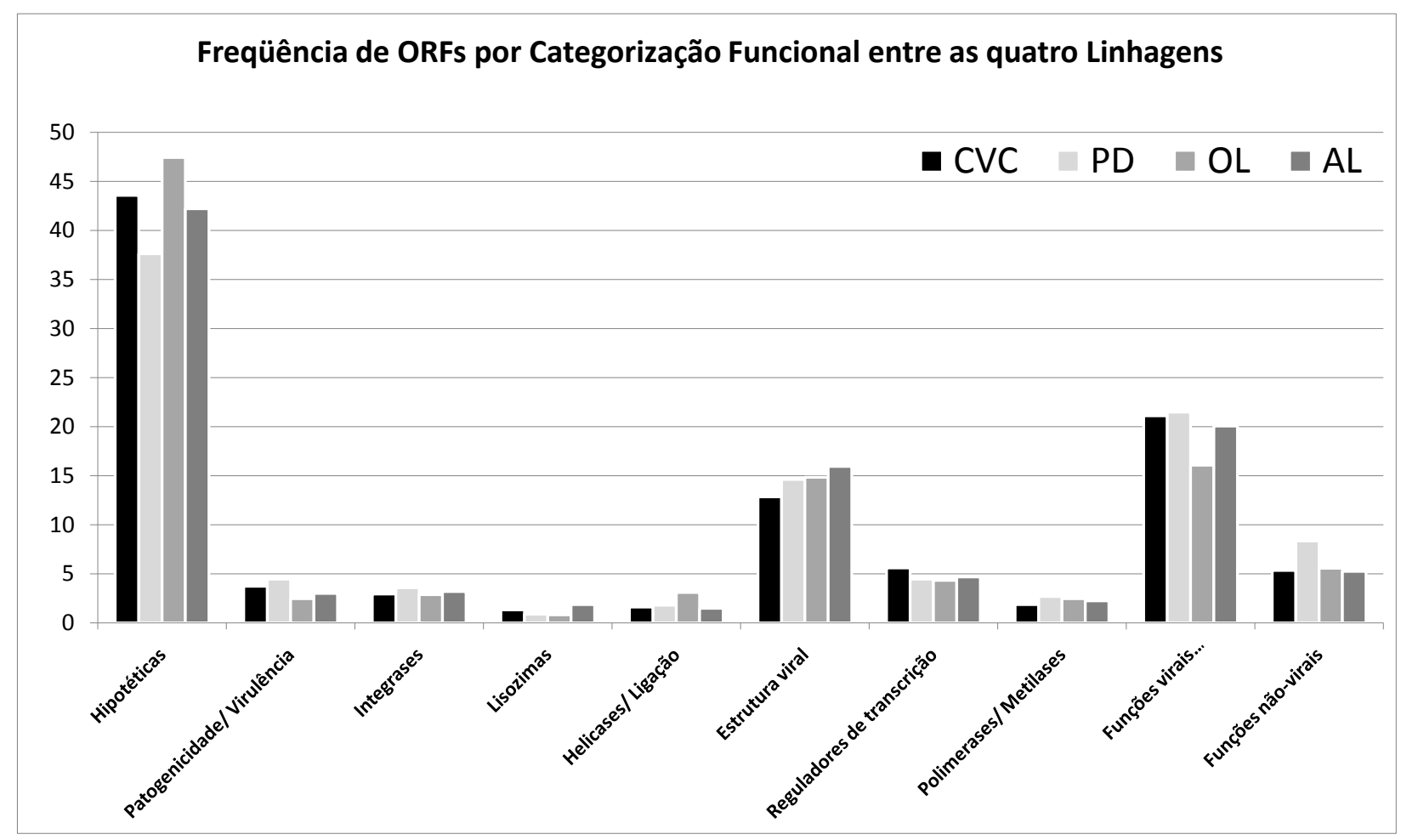

Figura 4.26. Freqüência das ORFs por categorias funcionais (materiais e métodos). Não foram contabilizadas as ORFs de IGs.

A Zonular occludens toxin (Zot), originalmente descrita em Vibrio cholerae, é uma proteína que aumenta a permeabilidade intestinal através da interação com um receptor celular, que subseqüentemente ativa uma sinalização celular com a função de desmontar as junções celulares. É encontrada no genoma do fago phiCTX (Di Pierro et al., 2001); a princípio, essa toxina não possui características que possam estar relacionada à especificidade de hospedeiro e patogenicidade de Xf, devido a ausência de citações na literatura sobre sua funcionalidade em tecido vegetal. Porém, esta toxina apresenta interesse biotecnológico, em particular na produção de vacinas, atuando como adjuvante ou sendo utilizada no tratamento de diabetes mellitus, permitindo a permeabilidade de insulina em tecido entérico (De Magistris, 2006; Fasano e Uzzau, 1997), sendo que atualmente algumas patentes em relação aos receptores de Zot já foram depositadas (por exemplo, United States Patent 5864014).

A virulence-associated protein E (vapE) também poderia estar relacionada a processos de virulência e é encontrada nas quatro linhagens; análises de BLAST indicam que apresentam ao menos 35\% de identidade com proteínas ortólogas presentes em Magnetospirillum magneticum, Oligotropha carboxidovorans, Pseudomonas mendocina, Pseudomonas syringae, Pseudomonas fluorescens, Pseudomonas putida, Burkholderia ambifaria, Burkholderia thailandensis e Burkholderia pseudomallei. 
Tabela 4.10. Conteúdo e freqüência das ORFs das regiões de profagos e IGs nas quatro linhagens de Xylella. Os números dentro dos parênteses representam o valor expresso em porcentagem.

\begin{tabular}{|c|c|c|c|c|c|}
\hline $\mathbf{X f}$ & Profago & Total & $\begin{array}{c}\text { Genes } \\
\text { essenciais }\end{array}$ & $\begin{array}{l}\text { Genes Não } \\
\text { essenciais }\end{array}$ & Hipotéticos \\
\hline \multirow{13}{*}{$\mathrm{Xf}-\mathrm{CVC}$} & xfp1 & $55(12,09)$ & $10(18,18)$ & $17(30,91)$ & $28(50,91)$ \\
\hline & $\mathrm{xfp} 2$ & $59(12,97)$ & $19(32,20)$ & $17(28,81)$ & $23(38,98)$ \\
\hline & xfp3 & $44(9,67)$ & $23(52,27)$ & $7(15,91)$ & $14(31,82)$ \\
\hline & $\mathrm{xfp} 4$ & $70(15,38)$ & $34(48,57)$ & $9(12,86)$ & $27(38,57)$ \\
\hline & xfp5 & $30(6,59)$ & $7(23,33)$ & $4(13,33)$ & $19(63,33)$ \\
\hline & xfp6 & $55(12,09)$ & $18(32,73)$ & $8(14,55)$ & $29(52,73)$ \\
\hline & giCVC & $78(17,14)$ & $5(6,41)$ & $37(47,44)$ & $36(46,15)$ \\
\hline & cve-r1 & $8(1,76)$ & $1(12,50)$ & $1(12,50)$ & $6(75,00)$ \\
\hline & cve-r2 & $1(0,22)$ & $0(0,00)$ & $1(100,00)$ & $0(0,00)$ \\
\hline & cve-r3 & $13(2,86)$ & $3(23,08)$ & $1(7,69)$ & $9(69,23)$ \\
\hline & cve-r4 & $20(4,40)$ & $14(70,00)$ & $1(5,00)$ & $5(25,00)$ \\
\hline & cve-r5 & $22(4,84)$ & $7(31,82)$ & $2(9,09)$ & $13(59,09)$ \\
\hline & Total & 455 & $173(38,02)$ & $73(16,05)$ & $209(45,93)$ \\
\hline \multirow{11}{*}{ Xf-PD } & xpd1 & $71(21,32)$ & $26(36,62)$ & $21(29,58)$ & $24(33,80)$ \\
\hline & xpd2 (giPD) & $81(24,32)$ & $41(50,62)$ & $11(13,58)$ & $29(35,80)$ \\
\hline & xpd3 & $21(6,31)$ & $7(33,33)$ & $8(38,10)$ & $6(28,57)$ \\
\hline & xpd4 & $22(6,61)$ & $13(59,09)$ & $4(18,18)$ & $5(22,73)$ \\
\hline & $\mathrm{xpd} 5$ & $41(12,31)$ & $12(29,27)$ & $4(9,76)$ & $25(60,98)$ \\
\hline & xpd6 & $40(12,01)$ & $23(57,50)$ & $2(5,00)$ & $15(37,50)$ \\
\hline & xpd7 & $27(8,11)$ & $3(11,11)$ & $3(11,11)$ & $21(77,78)$ \\
\hline & xpd8 & $21(6,31)$ & $6(28,57)$ & $3(14,29)$ & $12(57,14)$ \\
\hline & pd-r1 & $8(2,40)$ & $3(37,50)$ & $1(12,50)$ & $4(50,00)$ \\
\hline & pd-r2 & $1(0,30)$ & $0(0,00)$ & $1(100,00)$ & $0(0,00)$ \\
\hline & Total & 333 & $134(40,24)$ & $58(17,42)$ & $141(42,04)$ \\
\hline \multirow{12}{*}{$\mathbf{X f - O L}$} & xop1 & $24(4,98)$ & $7(29,17)$ & $13(54,17)$ & $4(16,67)$ \\
\hline & xop2 & $39(8,09)$ & $7(17,95)$ & $9(23,08)$ & $23(58,97)$ \\
\hline & xop3 & $53(11,00)$ & $17(32,08)$ & $14(26,42)$ & $22(41,51)$ \\
\hline & xop4 & $37(7,68)$ & $18(48,65)$ & $4(10,81)$ & $15(40,54)$ \\
\hline & xop5 & $33(6,85)$ & $5(15,15)$ & $3(9,09)$ & $25(75,76)$ \\
\hline & xop6 & $52(10,79)$ & $11(21,15)$ & $6(11,54)$ & $35(67,31)$ \\
\hline & xop7 & $64(13,28)$ & $18(28,13)$ & $9(14,06)$ & $37(57,81)$ \\
\hline & xop8 & $61(12,66)$ & $17(27,87)$ & $7(11,48)$ & $37(60,66)$ \\
\hline & xop9 & $58(12,03)$ & $25(43,10)$ & $10(17,24)$ & $23(39,66)$ \\
\hline & xop10 & $54(11,20)$ & $23(42,59)$ & $3(5,56)$ & $28(51,85)$ \\
\hline & ol-r1 & $7(1,45)$ & $3(42,86)$ & $1(14,29)$ & $3(42,86)$ \\
\hline & Total & 482 & $151(31,33)$ & $79(16,39)$ & $252(52,28)$ \\
\hline \multirow{15}{*}{ Xf-AL } & xap1 & $58(10,88)$ & $12(20,69)$ & $19(32,76)$ & $27(46,55)$ \\
\hline & xap2 & $29(5,44)$ & $9(31,03)$ & $7(24,14)$ & $13(44,83)$ \\
\hline & xap3 & $72(13,51)$ & $37(51,39)$ & $6(8,33)$ & $29(40,28)$ \\
\hline & xap4 & $30(5,63)$ & $13(43,33)$ & $4(13,33)$ & $13(43,33)$ \\
\hline & xap5 & $56(10,51)$ & $10(17,86)$ & $17(30,36)$ & $29(51,79)$ \\
\hline & xap6 & $53(9,94)$ & $19(35,85)$ & $19(35,85)$ & $15(28,30)$ \\
\hline & xap7 & $41(7,69)$ & $18(43,90)$ & $6(14,63)$ & $17(41,46)$ \\
\hline & xap8 & $52(9,76)$ & $14(26,92)$ & $6(11,54)$ & $32(61,54)$ \\
\hline & xap9 & $68(12,76)$ & $21(30,88)$ & $10(14,71)$ & $37(54,41)$ \\
\hline & xap10 & $27(5,07)$ & $10(37,04)$ & $2(7,41)$ & $15(55,56)$ \\
\hline & xap11 & $21(3,94)$ & $16(76,19)$ & $2(9,52)$ & $3(14,29)$ \\
\hline & al-r1 & $2(0,38)$ & $0(0,00)$ & $1(50,00)$ & $1(50,00)$ \\
\hline & al-r2 & $14(2,63)$ & $4(28,57)$ & $2(14,29)$ & $8(57,14)$ \\
\hline & al-r3 & $10(1,88)$ & $1(10,00)$ & $1(10,00)$ & $8(80,00)$ \\
\hline & Total & 533 & $184(34,52)$ & $102(19,14)$ & $247(46,34)$ \\
\hline \multicolumn{2}{|c|}{ Total Geral } & 1803 & $642(35,61)$ & $312(17,30)$ & $849(47,09)$ \\
\hline
\end{tabular}


Tabela 4.11. Conteúdo e freqüência das ORFs consideradas específicas/exclusivas das regiões de profagos nas quatro linhagens de Xylella. Os números dentro dos parênteses representam o valor expresso em porcentagem.

\begin{tabular}{|c|c|c|c|c|c|}
\hline $\mathbf{X f}$ & Profago & Total & $\begin{array}{c}\text { Genes } \\
\text { essenciais }\end{array}$ & $\begin{array}{c}\text { Genes Não } \\
\text { essenciais }\end{array}$ & Hipotéticos \\
\hline \multirow{13}{*}{ Xf-CVC } & xfp1 & $9(6,56)$ & $0(0,00)$ & $0(0,00)$ & $9(100,00)$ \\
\hline & $\mathrm{xfp} 2$ & $8(5,83)$ & $1(6,66)$ & $1(6,66)$ & $6(75,00)$ \\
\hline & $\mathrm{xfp} 3$ & $4(2,91)$ & $2(50,00)$ & $0(0,00)$ & $2(50,00)$ \\
\hline & xfp4 & $2(1,45)$ & $0(0,00)$ & $0(0,00)$ & $2(100,00)$ \\
\hline & $\mathrm{xfp} 5$ & $11(9,02)$ & $1(9,09)$ & $0(0,00)$ & $10(90,91)$ \\
\hline & xfp6 & $3(2,18)$ & $0(0,00)$ & $0(0,00)$ & $3(100,00)$ \\
\hline & giCVC & $75(55,97)$ & $5(6,66)$ & $37(49,33)$ & $36(48,00)$ \\
\hline & cve-r1 & $2(1,45)$ & $0(0,00)$ & $0(0,00)$ & $2(100,00)$ \\
\hline & cve-r2 & $0(0,00)$ & $0(0,00)$ & $0(0,00)$ & $0(0,00)$ \\
\hline & cve-r3 & $8(5,83)$ & $0(0,00)$ & $0(0,00)$ & $8(100,00)$ \\
\hline & cve-r4 & $3(2,18)$ & $3(100,00)$ & $0(0,00)$ & $0(0,00)$ \\
\hline & cve-r5 & $9(6,56)$ & $3(33,33)$ & $0(0,00)$ & $6(66,67)$ \\
\hline & Total & 134 & $15(11,19)$ & $38(28,35)$ & $84(62,68)$ \\
\hline \multirow{11}{*}{ Xf-PD } & xpd1 & $11(16,18)$ & $3(27,27)$ & $0(0,00)$ & $8(72,73)$ \\
\hline & xpd2 (giPD) & $17(25,00)$ & $2(11,76)$ & $5(29,41)$ & $10(58,82)$ \\
\hline & $x p d 3$ & $3(4,41)$ & $3(100,00)$ & $0(0,00)$ & $0(0,00)$ \\
\hline & xpd4 & $1(1,47)$ & $1(100,00)$ & $0(0,00)$ & $0(0,00)$ \\
\hline & xpd5 & $20(29,41)$ & $5(25,00)$ & $0(0,00)$ & $15(75,00)$ \\
\hline & xpd6 & $7(10,29)$ & $2(28,57)$ & $3(42,86)$ & $2(28,57)$ \\
\hline & xpd7 & $1(1,47)$ & $0(0,00)$ & $0(0,00)$ & $1(100,00)$ \\
\hline & xpd8 & $7(10,29)$ & $1(14,29)$ & $2(28,57)$ & $4(57,14)$ \\
\hline & pd-r1 & $1(1,47)$ & $0(0,00)$ & $0(0,00)$ & $1(100,00)$ \\
\hline & pd-r2 & $0(0,00)$ & $0(0,00)$ & $0(0,00)$ & $0(0,00)$ \\
\hline & Total & 68 & $17(25,00)$ & $10(14,71)$ & $41(60,29)$ \\
\hline \multirow{12}{*}{ Xf-OL } & xop1 & $1(0,79)$ & $1(100,00)$ & $0(0,00)$ & $0(0,00)$ \\
\hline & xop2 & $9(7,09)$ & $0(0,00)$ & $0(0,00)$ & $9(100,00)$ \\
\hline & xop3 & $8(6,30)$ & $1(12,50)$ & $1(12,50)$ & $6(75,00)$ \\
\hline & xop4 & $9(7,09)$ & $3(33,33)$ & $0(0,00)$ & $6(66,67)$ \\
\hline & xop5 & $14(11,02)$ & $1(7,14)$ & $2(14,29)$ & $11(78,57)$ \\
\hline & xop6 & $7(5,51)$ & $0(0,00)$ & $0(0,00)$ & $7(100,00)$ \\
\hline & xop7 & $26(20,47)$ & $5(19,23)$ & $0(0,00)$ & $21(80,77)$ \\
\hline & xop8 & $28(22,05)$ & $9(32,14)$ & $1(3,57)$ & $18(64,29)$ \\
\hline & xop9 & $12(9,45)$ & $2(16,67)$ & $2(16,67)$ & $8(66,67)$ \\
\hline & xop10 & $13(10,24)$ & $3(23,08)$ & $1(7,69)$ & $9(69,23)$ \\
\hline & ol-r1 & $0(0,00)$ & $0(0,00)$ & $0(0,00)$ & $0(0,00)$ \\
\hline & Total & 127 & $25(19,69)$ & $7(5,51)$ & $95(74,80)$ \\
\hline \multirow{15}{*}{ Xf-AL } & xap1 & $1(1,16)$ & $0(0,00)$ & $0(0,00)$ & $1(100,00)$ \\
\hline & xap2 & $11(12,79)$ & $4(36,36)$ & $1(9,09)$ & $6(54,55)$ \\
\hline & xap3 & $6(6,98)$ & $0(0,00)$ & $1(16,67)$ & $5(83,33)$ \\
\hline & xap4 & $5(5,81)$ & $1(20,00)$ & $2(40,00)$ & $2(40,00)$ \\
\hline & xap5 & $10(11,63)$ & $4(40,00)$ & $0(0,00)$ & $6(60,00)$ \\
\hline & xap6 & $2(2,33)$ & $0(0,00)$ & $0(0,00)$ & $2(100,00)$ \\
\hline & xap7 & $4(4,65)$ & $1(25,00)$ & $0(0,00)$ & $3(75,00)$ \\
\hline & xap8 & $9(10,47)$ & $0(0,00)$ & $1(11,11)$ & $8(88,89)$ \\
\hline & xap9 & $12(13,95)$ & $3(25,00)$ & $1(8,33)$ & $8(66,67)$ \\
\hline & xap10 & $19(22,09)$ & $1(5,26)$ & $5(26,32)$ & $13(68,42)$ \\
\hline & xap11 & $0(0,00)$ & $0(0,00)$ & $0(0,00)$ & $0(0,00)$ \\
\hline & al-r1 & $0(0,00)$ & $0(0,00)$ & $0(0,00)$ & $0(0,00)$ \\
\hline & al-r2 & $3(3,49)$ & $0(0,00)$ & $0(0,00)$ & $3(100,00)$ \\
\hline & al-r3 & $4(4,65)$ & $0(0,00)$ & $0(0,00)$ & $4(100,00)$ \\
\hline & Total & 86 & $14(16,28)$ & $11(12,79)$ & $61(70,93)$ \\
\hline \multicolumn{2}{|c|}{ Total Geral } & 415 & $66(19,41)$ & $29(8,53)$ & $245(72,06)$ \\
\hline
\end{tabular}


Também são identificadas um grupo de toxinas com suas respectivas anti-toxinas associadas, sempre organizadas lado a lado. O sistema de toxina e anti-toxina está relacionado à especificidade de infecção de determinado fago, impedindo assim que um outro fago similar invada o genoma da bactéria, implicando em efeitos na estabilidade genômica, transferência gênica lateral, crescimento e sobrevivência bacteriana (Magnuson, 2007). Ao todo, são identificados dois grupos distintos de relB/relE, que não compartilham similaridade entre si, e três grupos distintos de higA/higB, que também não compartilham similaridade (Tabela 4.12). Algumas regiões de profagos apresentam mais de uma cópia de sistema de toxina e anti-toxina: xfp4 tem uma cópia de relE/relB e duas cópias de higA/higB, enquanto xap3 e xap9 apresentam uma cópia de cada sistema. Quando comparadas com o banco de dados do GenBank, verifica-se que estas proteínas apresentam distribuição ampla de ortólogos pertencentes ao grupo das proteobactérias, sendo que também são encontradas em Cianobactérias e Actinobactérias.

Ainda dentro do grupo de ORFs não essenciais para fagos que agrupam-se em BBHs, destacam-se: (a) proteína inibidora de crescimento celular em cvc-r5 e xop7; (b) transposase similar à família IS200/IS605 em xfp6, xpd4, xop4 e xap8; (c) fimbrilina do tipo IV em xfp6, xpd1, xор5, xор6, хор7, хор8, хар2, xap4 e xap8, sendo que De La Fuente e colaboradores (2007) afirmam que esta proteína está relacionada com a mobilidade de Xf no meio, em particular com a aderência a superfícies; (d) acetiltransferase (UDP-3-O-[3-hydroxymyristoyl] glucosamine $\mathrm{N}$-acyltransferase) em xfp4, xfp6, xpd2, xap4 e xap8 (proteína não exclusiva das regiões de profagos, sendo também encontradas cópias desta ORF ao longo do genoma das quatro linhagens).

Dentro do grupo de ORFs exclusivas/específicas, a grande maioria é de ORF hipotéticas ou hipotéticas conservadas (Figura 4.25B); merecem destaque as ORFs não essenciais para fagos, que podem estar relacionadas, de alguma forma, à virulência das diferentes linhagens de Xf. Xf-CVC e Xf-AL, por exemplo, possuem virulence-associated proteins (em xfp3 e xap10). Xf-PD e Xf-AL possuem sistemas de restrição do tipo II específicos (metilase de modificação e enzima de restrição NspV em xpd8 e metilase de modificação e enzima de restrição NgoMIV em xap4). Xf-PD e Xf-OL possuem proteínas envolvidas em conjugação (conjugal transfer protein TraD em xpd2; TrbL e TrnN em xpd6; e TrbD em xop3).

Nas regiões de IGs ocorre a incidência de grande número de ORF que não se agrupam em BBHs e não apresentam conteúdo gênico predito relacionado a fagos: 75 (96\%) e 7 (87\%) ORFs para giCVC e giPD, respectivamente. Porém, algumas destas ORFs apresentam cópias em outras regiões do genoma que não estão relacionadas com elementos genéticos móveis e estão presentes em todas as linhagens, como (a) hemaglutinina com FS em giPD; (b) Flavoproteína 
repressora de triptofano em giCVC; (c) NADP Álcool desidrogenase em giCVC; (d) Zn dependente álcool desidrogenase. As demais ORFs presentes nas IGs são específicas para cada linhagem (a tabela completa com a listagem destas ORFs pode ser acessada pelo banco de dados deste projeto http://gracilaria.ib.usp.br/integraseDB).

Portanto, considerando-se que as principais diferenças genômicas entre as linhagens estão relacionadas às inserções de regiões de profagos e IGs, pode-se sugerir que todas as ORFs não essenciais para fagos (tanto as que formam clusters BBH como as exclusivas/específicas), assim como as ORF específicas identificadas nas IGs, possam apresentar papel fundamental, seja com correlação direta no mecanismo de virulência do fago, ou desempenhando papel fundamental para a patogenicidade e/ou adaptação da bactéria ao meio.

Analisando-se o conteúdo gênico predito de cada região relacionada a profago individualmente e comparando-se com o conjunto de genes essenciais do bacteriófago lambda, não é possível afirmar, com exatidão, quais profagos estão completos (ou seja, capazes de sofrer indução para o ciclo lítico), pois não apresentam todos os genes de lambda bem caracterizados. Porém, é possível listar as regiões de profagos que são candidatas a fagos completos (Tabela 4.13), sendo que para isso atribuiu-se um tamanho mínimo de $30 \mathrm{~kb}$ para a região candidata, presença de ao menos 10 ORFs essenciais de fagos, sendo do grupo de ORFs não estruturais, contabilizadas as integrases completas, polimerases, helicases, repressores, anti-repressores e lisozimas e no grupo das ORFs estruturais a placa da base, cauda, fibras da cauda e capsídeo. ORFs relacionadas a fagos, porém sem função definida, também foram contabilizadas. Em cada linhagem, ao menos duas regiões candidatas puderam ser identificadas. Xf-AL, além de apresentar maior quantidade de integrases e regiões de profagos, também apresenta pelo menos o dobro de profagos supostamente completos, em relação às outras linhagens.

Uma segunda análise do conteúdo gênico predito das ORFs essenciais de fagos foi conduzida especificamente no grupo de ORFs estruturais, ou seja, relacionadas à estrutura da partícula do fago. Essas ORFs foram analisadas através da ferramenta phage-navigatorcomparative a fim de identificar o padrão de agrupamento delas por metodologia de BBHs frente às ORFs estruturais de 402 genomas de fagos depositados no GenBank (Figura 4.27). Este resultado associa as ORF estruturais de cada região relacionada a profagos de Xf com as principais famílias de fagos conhecidas (fonte: ICTVdB - The Universal Virus Database, version $4)$. 
Tabela 4.12. Grupo de BBHs relacionados a toxinas e anti-toxinas identificadas nas regiões de profagos. Foram identificados 2 grupos de relB/relE e 3 grupos de higA/higB. Em destaque, as regiões de profagos que apresentam mais de uma cópia.

\begin{tabular}{|c|c|c|c|c|}
\hline ORF & Produto & Fago & ORF & Tamanho $(\mathbf{p b})$ \\
\hline \multirow{3}{*}{ relB_l } & \multirow{3}{*}{ Addiction module antitoxin, RelB/DinJ family protein } & xop1 & $\mathrm{XO} 23812$ & 88 \\
\hline & & xap1 & XA23064 & 88 \\
\hline & & xpd1 & XP15344 & 88 \\
\hline \multirow{3}{*}{ relE_l } & \multirow{3}{*}{ Addiction module toxin, RelE/StbE family protein } & xop1 & XO07283 & 94 \\
\hline & & xap1 & XA23063 & 94 \\
\hline & & xpd 1 & XP15356 & 94 \\
\hline \multirow{3}{*}{ relB_2 } & \multirow{3}{*}{ Addiction module antitoxin, RelB/DinJ family protein } & xfp4 (*) & XF20114 & 76 \\
\hline & & $\operatorname{xap3}(*)$ & XA21143 & 76 \\
\hline & & xpd4 (*) & XP32249 & 76 \\
\hline \multirow{3}{*}{$r e l E \_2$} & \multirow{3}{*}{ Addiction module toxin, RelE/StbE family protein } & xfp4 (*) & XF20098 & 92 \\
\hline & & $\operatorname{xap3}(*)$ & XA21144 & 89 \\
\hline & & xpd4 $(*)$ & XP16391 & 89 \\
\hline \multirow{3}{*}{ higA_l } & \multirow{3}{*}{$\begin{array}{l}\text { Addiction module antidote protein, HTH-type } \\
\text { (Plasmid maintenance system antidote protein) }\end{array}$} & $\operatorname{xap3}(*)$ & XA21124 & 383 \\
\hline & & $\operatorname{xap9}(*)$ & XA41142 & 372 \\
\hline & & xfp4 (*) & XF20207 & 372 \\
\hline \multirow{3}{*}{$h i g B \_1$} & \multirow{3}{*}{$\begin{array}{l}\text { Addiction module killer protein } \\
\text { (Plasmid maintenance system killer protein) }\end{array}$} & $\operatorname{xap3}(*)$ & XA21123 & 100 \\
\hline & & $\operatorname{xap9}(*)$ & XA19460 & 100 \\
\hline & & xfp4 (*) & XF20212 & 97 \\
\hline \multirow{5}{*}{ higA_2 } & \multirow{5}{*}{$\begin{array}{l}\text { Addiction module antidote protein, HTH-type } \\
\text { (Plasmid maintenance system antidote protein) }\end{array}$} & xap5 & XA24235 & 92 \\
\hline & & xap6 & XA21458 & 92 \\
\hline & & xfp1 & XF08455 & 92 \\
\hline & & xop3 & XO62659 & 80 \\
\hline & & xpd3 & XP05338 & 92 \\
\hline \multirow{4}{*}{$h i g B \_2$} & \multirow{4}{*}{$\begin{array}{l}\text { Addiction module killer protein } \\
\text { (Plasmid maintenance system killer protein) }\end{array}$} & xap5 & XA24236 & 95 \\
\hline & & xap6 & XA40582 & 116 \\
\hline & & xfp1 & XF34872 & 94 \\
\hline & & xpd3 & XP32268 & 94 \\
\hline \multirow{10}{*}{ higA_3 } & \multirow{10}{*}{$\begin{array}{l}\text { Addiction module antidote protein, HTH-type } \\
\text { (Plasmid maintenance system antidote protein) }\end{array}$} & cve-r3 & XF33275 & 103 \\
\hline & & xap11 & XA22500 & 103 \\
\hline & & $\operatorname{xap} 3(*)$ & XA21133 & 103 \\
\hline & & $\operatorname{xap9}(*)$ & XA41205 & 100 \\
\hline & & xfp3 & XF18923 & 100 \\
\hline & & xfp4 $(*)$ & XF20162 & 102 \\
\hline & & xор4 & XO63364 & 102 \\
\hline & & xор4 & XO53359 & 103 \\
\hline & & хор9 & XO06454 & 102 \\
\hline & & xpd6 & XP16334 & 102 \\
\hline \multirow{10}{*}{ higB_3 } & \multirow{10}{*}{$\begin{array}{l}\text { Addiction module killer protein } \\
\text { (Plasmid maintenance system killer protein) }\end{array}$} & cve-r3 & XF35120 & 100 \\
\hline & & xap11 & XA40970 & 99 \\
\hline & & $\operatorname{xap3}(*)$ & XA21132 & 100 \\
\hline & & $\operatorname{xap9}(*)$ & XA19469 & 99 \\
\hline & & xfp3 & XF18930 & 99 \\
\hline & & xfp4 (*) & XF20167 & 101 \\
\hline & & xop4 & XO64392 & 99 \\
\hline & & xop4 & XO64291 & 100 \\
\hline & & xор9 & XO23825 & 99 \\
\hline & & xpd6 & XP16330 & 99 \\
\hline
\end{tabular}


Tabela 4.13. Regiões de profagos candidatas a serem consideradas fagos completos capazes de sofrer indução ao ciclo lítico.

\begin{tabular}{cccc}
\hline Região & Tamanho & Genes Essenciais & $\begin{array}{c}\text { Genes relacionados a fagos } \\
\text { sem função definida }\end{array}$ \\
\hline xfp1 & $42 \mathrm{~kb}$ & 17 & 4 \\
xfp2 & $45 \mathrm{~kb}$ & 17 & 11 \\
\hline xpd1 & $56 \mathrm{~kb}$ & 21 & 14 \\
xpd2 & $62 \mathrm{~kb}$ & 11 & 28 \\
\hline xop3 & $41 \mathrm{~kb}$ & 14 & 9 \\
xop9 & $43 \mathrm{~kb}$ & 10 & 20 \\
\hline xap1 & $41 \mathrm{~kb}$ & 19 & 5 \\
xap5 & $39 \mathrm{~kb}$ & 17 & 3 \\
xap6 & $39 \mathrm{~kb}$ & 19 & 10 \\
xap9 & $45 \mathrm{~kb}$ & 10 & 16 \\
\hline
\end{tabular}

Os resultados sugerem que a provável origem das regiões de profagos esteja próxima à família Siphoviridae, grupo de mais de $50 \%$ dos membros dos $\mathrm{BBHs}$, e representada por fagos com longas caudas não-retráteis, como por exemplo o fago lambda. Porém, apesar da prevalência, outras famílias também estão presentes em freqüência relevante, como Myoviridae $(21,71 \%)$ e Podoviridae (12,86\%). Quando cada região relacionada a profago é examinada independentemente, estas proporções não sofrem variação considerável, sugerindo a hipótese que todas as regiões de profagos presentes nestas quatro linhagens de Xf possam ser provenientes de um mesmo fago ancestral comum.

Desta forma, com base nestes resultados, é possível apontar que as ORFs estruturais das regiões de profagos de Xf apresentam constituição híbrida e/ou mosaica, assim como também é observado de maneira similar em fagos do tipo lambda (Clark et al., 2001; Juhala et al., 2000) e nos fagos que infectam o gênero Mycobacteria e a bactéria Burkholderia cepacia (Pedulla et al., 2003; Summer et al., 2006). 


\section{Xf-CVC}

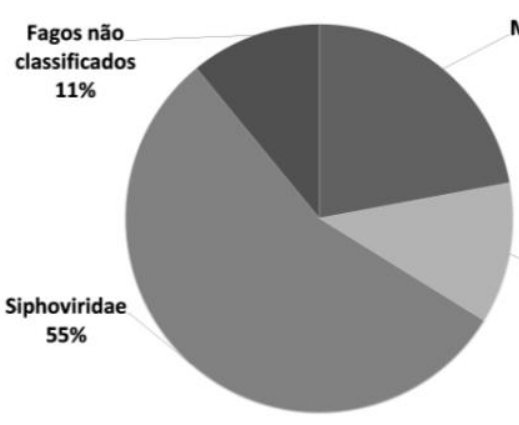

Myoviridae

$22 \%$

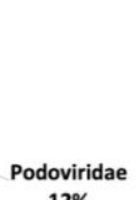

$12 \%$
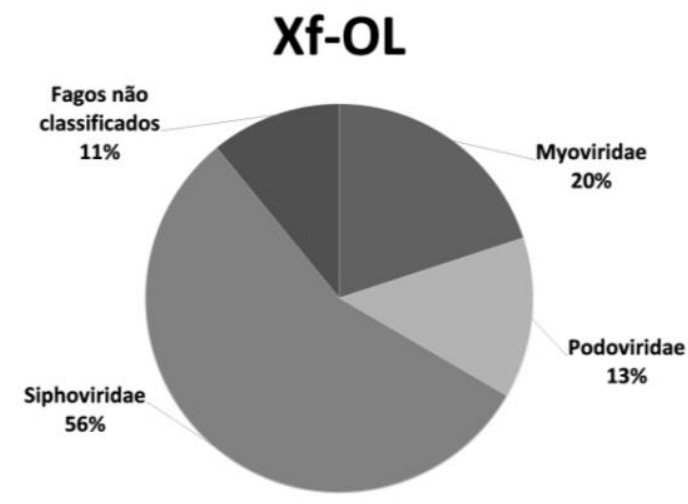

Xf-PD

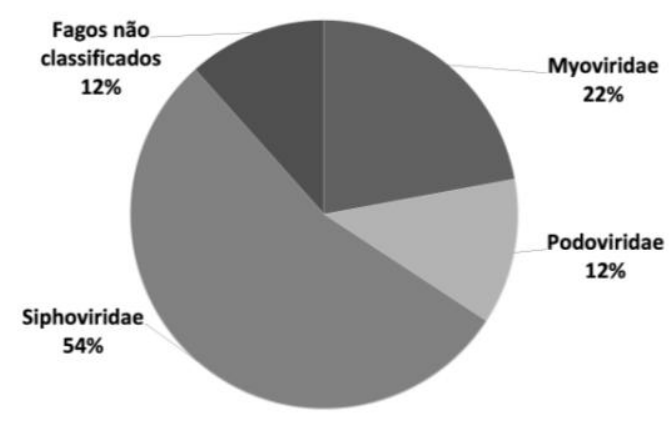

\section{Xf-AL}

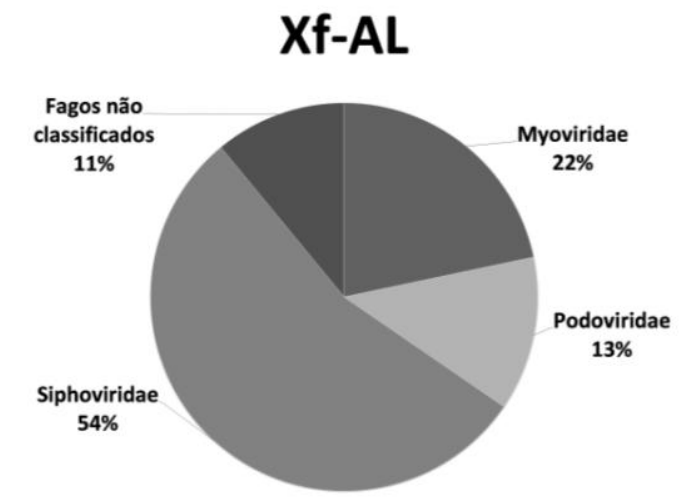

Figura 4.27. Freqüência de BBHs de ORFs estruturais associadas com famílias de fagos. ORFs estruturais das regiões de profagos nas quatro linhagens de $\mathrm{Xf}$ foram analisadas por metodologia de $\mathrm{BBH}$ frente às ORFs estruturais de 402 genomas de fagos depositados no GenBank. 


\subsection{ANÁliSE COMPARATIVA DAS REGIÕES RELACIONADAS A PROFAGOS}

Análises genômicas de fagos temperados sugerem que, após a integração no genoma hospedeiro, eles sofrem um complexo mecanismo de deteriorização, consistindo em mutações pontuais, rearranjos genômicos, mudanças modulares, invasão de outros elementos genéticos móveis e massiva deleção de seu DNA (Canchaya et al., 2003a). Para analisar se o mesmo processo ocorre nos profagos das quatro linhagens de $\mathrm{Xf}$, e tentar inferir correlações entre os profagos, análises comparativas foram realizadas entre todas as regiões de profagos. Em primeiro lugar, foram identificadas as regiões de profagos que apresentam o mesmo contexto genômico de inserção entre diferentes linhagens, apresentadas na tabela 4.14A (e ilustradas no mapa da figura 4.24). O que se constata é a freqüente ocorrência da invasão de regiões de profagos em determinados sítios, onde 26 regiões compartilham determinados sítios entre linhagens diferentes (Tabela 4.14B).

Tabela 4.14. A) Posicionamento das regiões de profagos em relação ao contexto genômico (apresentado na figura 4.25). As oito letras $\left(^{\mathbf{a} \mathbf{b} \mathbf{c} \mathbf{d} \mathbf{e} \mathbf{f} \mathbf{g} \mathbf{~} \mathbf{i} \mathbf{j}}\right.$ ) nas regiões destacadas em negrito representam regiões de profagos inseridas no mesmo contexto genômico, entre linhagens diferentes. B) Regiões relacionadas que compartilham ao menos uma borda com mesmo contexto genômico.

\begin{tabular}{|c|c|c|c|c|c|c|c|c|c|c|c|}
\hline 5 , & Xf-CVC & $3^{\prime}$ & 5 ' & Xf-PD & 3 ' & 5 , & Xf-OL & 3' & 5 , & Xf-AL & 3 ' \\
\hline $\mathrm{D}$ & xfp1 & $\mathrm{E}$ & I & xpd1 $^{g}$ & $\mathbf{H}$ & $\mathbf{F}$ & xop1 $^{\mathbf{c}}$ & $\mathbf{F}$ & A & xap1 & M \\
\hline M & xfp2 & $\mathrm{E}$ & XPD5 & xpd2 & I & $\mathrm{F}$ & xop2 & $\mathrm{F}$ & G & xap2 ${ }^{f}$ & $\mathbf{J}$ \\
\hline G & $\mathrm{xfp} 3$ & $\mathrm{H}$ & $\mathbf{F}$ & $\operatorname{xpd}^{c}$ & $\mathbf{F}$ & $\mathrm{F}$ & xор3 & K & $\mathrm{J}$ & xap3 & $\mathrm{F}$ \\
\hline H & $x^{x p 4^{g}}$ & I & H & xpd $4^{b}$ & $\mathbf{K}$ & K & xop4 & B & $\mathrm{F}$ & xap4 & $\mathrm{C}$ \\
\hline $\mathrm{J}$ & xfp5 & $\mathrm{K}$ & $\mathrm{J}$ & xpd5 & XPD2 & B & xор5 & $\mathrm{C}$ & D & xар5 & A \\
\hline C & $x f p 6^{i}$ & D & $\mathbf{K}$ & $\operatorname{xpd}^{a}$ & $\mathbf{L}$ & $\mathrm{C}$ & xop6 & I & $\mathrm{F}$ & xap6 & I \\
\hline D & cve-r1 ${ }^{\text {e }}$ & D & B & $\operatorname{xpd} 7^{h}$ & $\mathbf{E}$ & I & xop $7^{j}$ & $\mathbf{J}$ & $\mathbf{H}$ & $x a p 7^{b}$ & $\mathbf{K}$ \\
\hline $\mathrm{E}$ & cve-r2 & $\mathrm{F}$ & C & $\operatorname{xpd}^{\mathrm{i}}$ & D & B & xop8 & $\mathrm{H}$ & $\mathrm{L}$ & xap8 & B \\
\hline $\mathbf{E}$ & cvc-r3 ${ }^{d}$ & $\mathbf{E}$ & G & pd-r1 ${ }^{f}$ & $\mathbf{J}$ & $\mathrm{H}$ & xop9 & $\mathrm{E}$ & B & xap9 $9^{h}$ & $\mathbf{E}$ \\
\hline $\mathbf{K}$ & cve-r4 ${ }^{a}$ & $\mathbf{L}$ & M & pd-r2 & D & G & xop10 ${ }^{a}$ & $\mathbf{L}$ & $\mathrm{F}$ & xap10 & $\mathrm{F}$ \\
\hline I & cve-r5 ${ }^{j}$ & $\mathbf{J}$ & & & & $\mathbf{J}$ & ol-r1 ${ }^{f}$ & G & $\mathbf{E}$ & ${\operatorname{xap} 11^{d}}^{d}$ & $\mathbf{E}$ \\
\hline & & & & & & & & & I & al-r1 ${ }^{\mathrm{g}}$ & $\mathbf{H}$ \\
\hline & & & & & & & & & $\mathbf{K}$ & al-r2 $^{a}$ & $\mathbf{L}$ \\
\hline & & & & & & & & & D & al-r3 $^{\mathrm{e}}$ & D \\
\hline
\end{tabular}

B

\begin{tabular}{c|c|c|c|c|c|c|c|c|c}
\hline A & B & C & D & E & F & G & H & I & J \\
\hline cvc-r4 & xpd4 & xpd3 & cvc-r1 & pd-r1 & cvc-r3 & al-r1 & xpd7 & xfp6 & cvc-r5 \\
xpd6 & xap7 & xop1 & al-r3 & ol-r1 & xap11 & xpd1 & xap9 & xpd8 & xop7 \\
xop10 & & & & xap2 & & xfp4 & & xop6 & xpd5 \\
al-r2 & & & & & & & & & \\
\hline
\end{tabular}




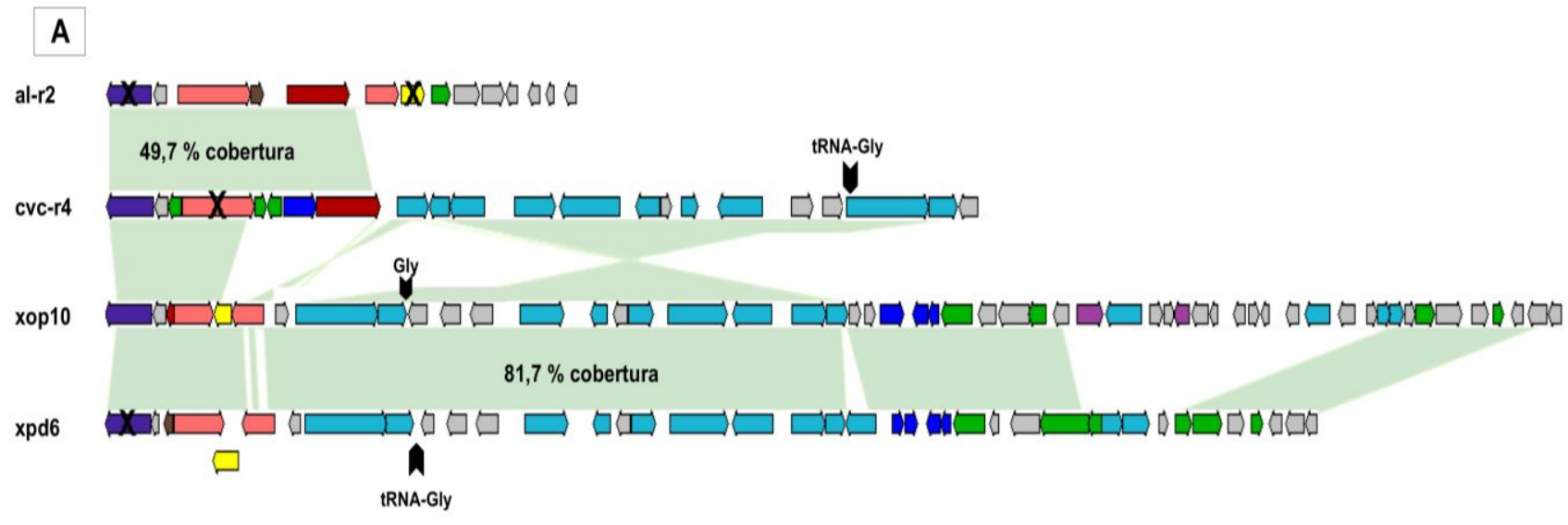

\section{B}

xpd4

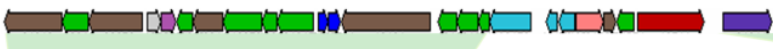

$51,6 \%$ cobertura

xap7 $\mathrm{X} \square \square \square \square \square(7)$

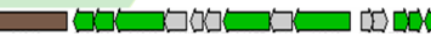

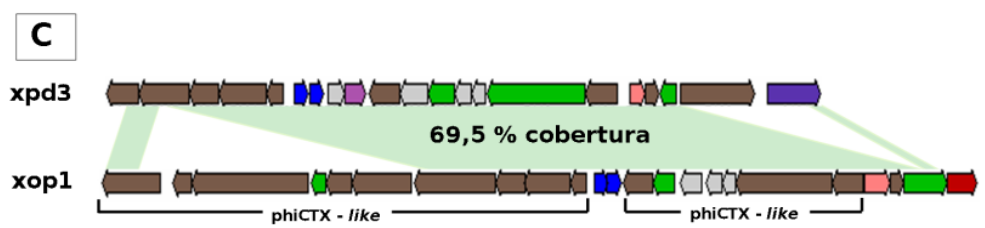

D
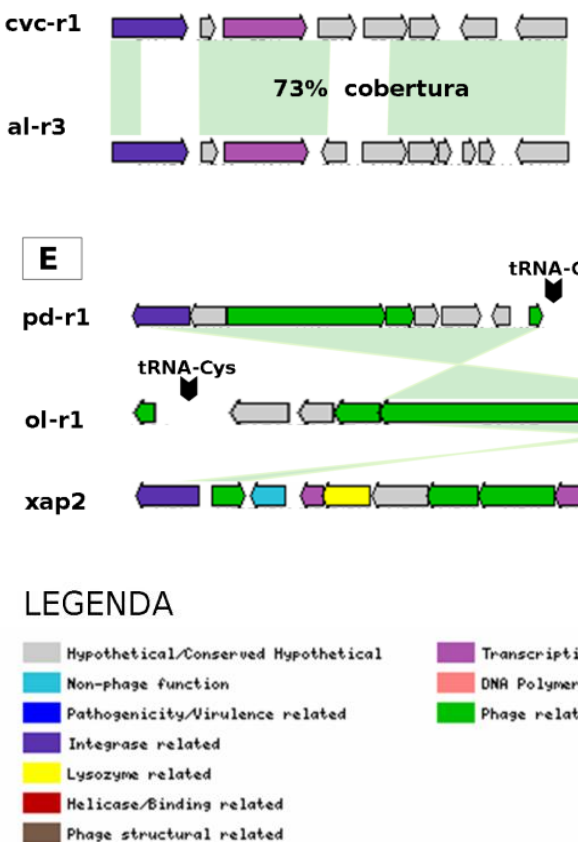

tRNA-Cys

D

प几

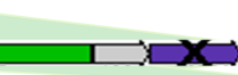

$\square$
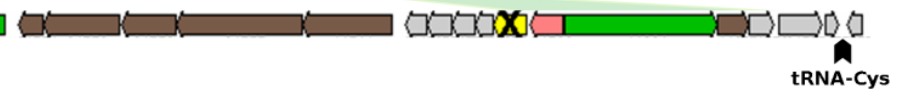

LEGENDA

Figura 4.28. Análise comparativa entre as regiões de profagos que apresentam mesmo contexto de inserção entre linhagens diferentes e com similaridade de nucleotídeos acima de 50\%. Esquema em forma de mapas genômicos; as cores de cada ORF representam categorização funcional indicada na legenda, e as barras em verde claro representam as regiões que apresentam similaridade de nucleotídeos acima de $80 \%$. 
Dentre as regiões que compartilham mesmo contexto genômico entre linhagens diferentes, apenas os casos A, B, C, D e E (Tabela 4.14 B e figura 4.28) apresentam similaridade de nucleotídeos acima de 55\% com cobertura de ao menos $50 \%$ da seqüência de cada região relacionada a profago, e não estão relacionadas a rearranjos genômicos, sugerindo tratar-se de eventos de inserção que ocorreram antes da separação destas quatro linhagens.

As regiões cvc-r4, xpd6, xop10 e al-r2 estão presentes nas quatro linhagens e contidas no mesmo contexto genômico, entre uma epsP sintase na borda 5' e um receptor TonBdependente na borda 3' (com exceção da borda 5' do xop10 que está ao lado de uma metiltransferase, indicando que neste caso houve rearranjo), sendo que a comparação entre estas regiões indica que cvc-r4 e al-r2 aparentemente são regiões que sofreram decaimento genômico a partir de um profago ancestral proveniente de xop10 ou xpd6. Os profagos xpd6 e xop10 apresentam similaridade de nucleotídeos acima de 70\%, ao longo de 97,5\% de suas seqüências (Figura 4.28A); no entanto, o proteoma apresenta 49\% de ORFs com provável função nãoessencial para fagos, $45 \%$ hipotéticas e apenas $6 \%$ de ORFs com provável função essencial para fagos, sendo que neste grupo não foram identificadas ORFs relacionadas à estrutura de partícula do fago, sugerindo tratar-se de regiões defectivas, incapazes de formar partícula de fago. A região xpd6 aparentemente sofreu deleções a partir de um ancestral similar a xop10, sendo as principais características: (a) xpd6 apresentar sua integrase com FS/SCF, sugerindo incapacidade de mobilização no genoma de Xf-PD; (b) a presença de uma cópia de uma virulence associated protein I e uma cópia do sistema de toxina e anti-toxina hicA/hicB; e (c) xpd6 sofreu a deleção de pelo menos 9 ORFs hipotéticas e de 2 ORFs relacionadas com o controle da transcrição.

Em xpd4 e xap7, a similaridade de nucleotídeos acima de 70\% abrange apenas 51,6\% de suas seqüências (Figura 4.28B) e estas regiões estão inseridas entre um cluster de ORFs com provável função relacionada a proteínas da família das ATP-binding proteins. Ambas são regiões relacionadas à profagos defectivos, sendo a principal característica relacionada à xap7 apresentar maior número de ORFs com provável função relacionada a fago em relação à xpd4, contendo inclusive uma ORF que codifica uma proteína lisozima (capaz de provocar lise celular).

Os profagos xop1 e xpd3 apresentam similaridade de seqüências de nucleotídeos acima de $70 \%$ ao longo de $96,6 \%$ de suas seqüências, estão inseridos entre uma lipídio sintase na porção 5'e uma provável proteína ParA na porção 3'. Ambos aparentam ser profagos defectivos, sendo as principais características relacionadas a: (a) ausência da integrase em xop1, (b) não apresentarem o conjunto completo de ORFs não estruturais de fagos, (c) a porção de ORFs estruturais apresentam organização semelhante à encontrada no fago phiCTX que infecta Pseudomonas aeruginosa (Nakayama et al., 1999), sugerindo um ancestral comum proveniente 
da família dos fagos do tipo P2, e (d) apresentam conjunto de toxina e anti-toxina (Figura 4.28C).

As regiões remanescentes de fagos cvc-r1 e al-r3 apresentam similaridade de $74 \%$ entre suas seqüências de nucleotídeos, estão inseridas entre uma ORF com produto hipotético na porção 5' e uma isomerase na porção 3', ambas apresentam aproximadamente 7,5 kb, e representam a "cicatriz" de um evento de inserção de profagos, pois já não apresentam nenhuma ORF essencial de fagos, exceto pela integrase, sugerindo tratar-se de uma inserção de profago que sofreu severo decaimento genômico (Figura 4.28D).

Por último, as regiões xap2, pd-r1 e ol-r1 estão inseridas entre uma fumarato hidratase na porção 5' e a uma proteína inibidora de divisão de glicose na porção 3'. As regiões pd-r1 e olr1 apresentam-se como regiões defectivas e aparentemente deterioradas a partir de xap2, sendo a principal característica a perda da ORF que codifica uma fimbrilina do tipo IV em pd-r1 e ol-r1 (porém não é uma ORF exclusiva e está presente em outras regiões de profagos nas quatro linhagens), e por ambas as regiões apresentarem associação com o único tRNA-CYS como sítio de inserção (Figura 4.28E).

As demais regiões de profagos que compartilham mesmo contexto genômico entre diferentes linhagens apresentam menos de 50\% de identidade de nucleotídeos com menos de $50 \%$ de cobertura de suas sequiências ( $\operatorname{casos} \mathbf{F}, \mathbf{G}, \mathbf{H}, \mathbf{I}$ e $\mathbf{J}$ na tabela 4.14B);elas aparentam ser originadas de eventos de inserção distintos, proveniente de fagos diferentes, sendo que sempre estão localizados ao lado de diferentes tipos de tRNAs, sugerindo tratar-se de fagos que utilizam tRNAs como sítio de inserção no cromossomo da bactéria. Esses casos estão descritos a seguir.

(F) cvc-r3 e xap11 apresentam menos de 30\% de identidade entre suas seqüências, estão localizadas entre um conjunto de tRNAs (PRO-ARG-HIS-LYS) na porção 5' ao lado do fragmento de integrase, e uma hemaglutinina na porção 3'. Ambas aparentam ser regiões deterioradas a partir de um mesmo ancestral comum, sendo que são as regiões que estão localizadas mais próximas da origem de replicação e não estão relacionadas a eventos de rearranjos genômicos.

(G) As regiões al-r1, xpd1 e xfp4 estão inseridas entre duas ORFs conservadas hipotéticas, não apresentam nenhuma identidade entre suas seqüências de nucleotídeos, indicando tratar-se de eventos distintos provenientes de fagos diferentes, sendo que essas regiões estão associadas a tRNAs (GLY, THR e ARG respectivamente) e estão localizadas próximas a região de término de replicação. 
(H) xpd7 e xap9 apresentam menos de 30\% de identidade entre suas seqüências de nucleotídeos, estão localizadas entre uma transposase na porção 5'e uma exonuclease na porção 3', sendo que também estão associados a um tRNA-VAL. A região xpd7 não apresenta ORFs relacionadas à estrutura da partícula do fago, sugerindo ser um profago defectivo.A região xap9 apresenta duas integrases, eé possível especular que esta região foi alvo de invasão para outro fago, servindo como sítio de inserção, e resultando em um profago truncado.

(I) xfp6, xpd8 e xop6 apresentam menos de 35\% de identidade entre suas seqüências, estão localizadas entre uma metionil tRNA sintetase na porção 5' e uma proteína PilE na porção 3' (exceto xop6 que está localizado ao lado de uma proteína de biossíntese de queuosine). A região xpd8 aparenta ser uma versão defectiva e deteriorada a partir de um fago ancestral, similar à região xfp6. A região xop6 aparenta ser um profago truncado. Estas regiões estão associadas aos tRNAs ASN para xfp6 e xpd8 e LYS para xop6.

(J) xop7, xpd5 e cvc-r5 apresentam menos de 35\% de identidade entre suas seqüências, estão localizadas entre uma proteína panK-III na porção 5' (exceto xpd5 que está localizado ao lado de uma proteína de biossíntese de queuosine) e uma fosfoglicerato mutase na porção 3'. A região xop7 apresenta duas integrases e, assim como a região xap9, aparenta ser uma região truncada pela inserção de um fago em um sítio que já continha um profago. As regiões cvc-r5 e xpd5 não apresentam integrase e contém pelo menos 8 ORFs com função relacionada a fago. Estão associadas ao tRNAs THR para xop7 e LYS para xpd5 e cvc-r5.

As demais semelhanças entre regiões de profagos estão relacionadas a compartilhamento de ORFs e similaridade de sequiência, porém com inserção em contexto genômico distinto e em alguns casos associados a diferentes tipos de tRNAs, sendo que sempre estão relacionadas a rearranjos genômicos. Desta forma, sugere-se que estas inserções foram originadas a partir de eventos independentes, produto de processo de infecção que ocorreu após o evento de separação das linhagens, portanto, sugerindo ser inserções mais recentes na história evolutiva destas quatro linhagens. Essas regiões estão descritas a seguir.

(1) xfp1, xfp2, xpd1, xop3, xap1 e xap5 apresentam média de 88\% de suas seqüências de nucleotídeos (média de $40 \mathrm{~kb}$ para cada região) com similaridade de sequiência de nucleotídeo acima de $70 \%$. A organização e orientação das ORFs são conservadas entre estas regiões, sendo que a ORF que codifica para a lisozima separa o grupo de ORFs não estruturais das ORFs estruturais (xop3 é exceção e não apresenta lisozima). A região xap6, quando comparada a este grupo, apresenta similaridade apenas na porção de ORFs estruturais de fagos. A porção de ORFs não estruturais é composta principalmente pela integrase, DNA helicase, DNA polimerase, 
repressor e anti-repressor e DNA primase, apresentando similaridade a região equivalente do fago APSE-1 (van der Wilk et al., 1999) que infecta um endosimbionte de Acyrthosiphon pisum $^{l}$; enquanto a porção de ORFs estruturais apresenta organização similar à encontrada em fagos do tipo lambda (considerando-se as ORFs que codificam o capsídeo e as enzimas encarregadas no empacotamento do DNA) e organização similar a fagos do tipo P2 (phiCTX) entre as ORFs que codificam a placa da base, cauda e fibras da cauda (gpV, gpW, gpJ, gpI, gpU, gpX and gpD), sugerindo tratar-se de um profago híbrido. Entre estes dois grupos de ORFs, aparecem duas ORFs que codificam sistema de toxina e anti-toxinas (na mesma posição na região xfp2 há um regulador da transcrição) (Figura 4.29). Estas regiões aparentemente apresentam o conjunto completo de genes essenciais para bacteriófagos (xop3 é exceção por não apresentar lisozima), sugerindo que esses profagos podem apresentar possibilidade de conversão para ciclo lítico, caso sejam transcritos (Tabela 4.13).

(2) xfp3, xfp4, xpd2, xop9, xap3, xap7 e xap9 apresentam similaridade de seqüências de até $70 \%$ apenas na porção de ORFs estruturais; aparentemente, essas regiões não apresentam o conjunto completo de ORFs essenciais para bacteriófagos, especificamente no conjunto de ORFs responsáveis pela replicação do DNA. A porção de ORFs estruturais apresenta organização similar à encontrada no profago 4 que infecta a bactéria Listeria innocua (derivado do fago do tipo Sfi11) e também com o fago АaФ23 que infecta Actinobacillus actinomycetemcomitans ${ }^{2}$, um patógeno relacionado com inflamação da cavidade oral de humanos (Resch et al., 2004). Na porção de ORFs estruturais, a região xpd2 carrega a ilha genômica giPD entre uma ORF com função relacionada a fago na porção 5' e uma terminase de fago na porção 3', sendo que é exclusiva para esta linhagem. Assim como nas regiões apresentadas anteriormente, uma lisozima é responsável pela divisão entre o conjunto de ORFs estruturais e não estruturais, exceto pela região xop9, que não possui lisozima (Figura 4.30).

\footnotetext{
${ }^{1}$ Previamente descrito para xfp1 e xfp2 por Canchaya e colaboradores (2003).

${ }^{2}$ Previamente descrito para xfp3 e xfp4 por Canchaya e colaboradores (2003) e Resch e colaboradores (2004).
} 


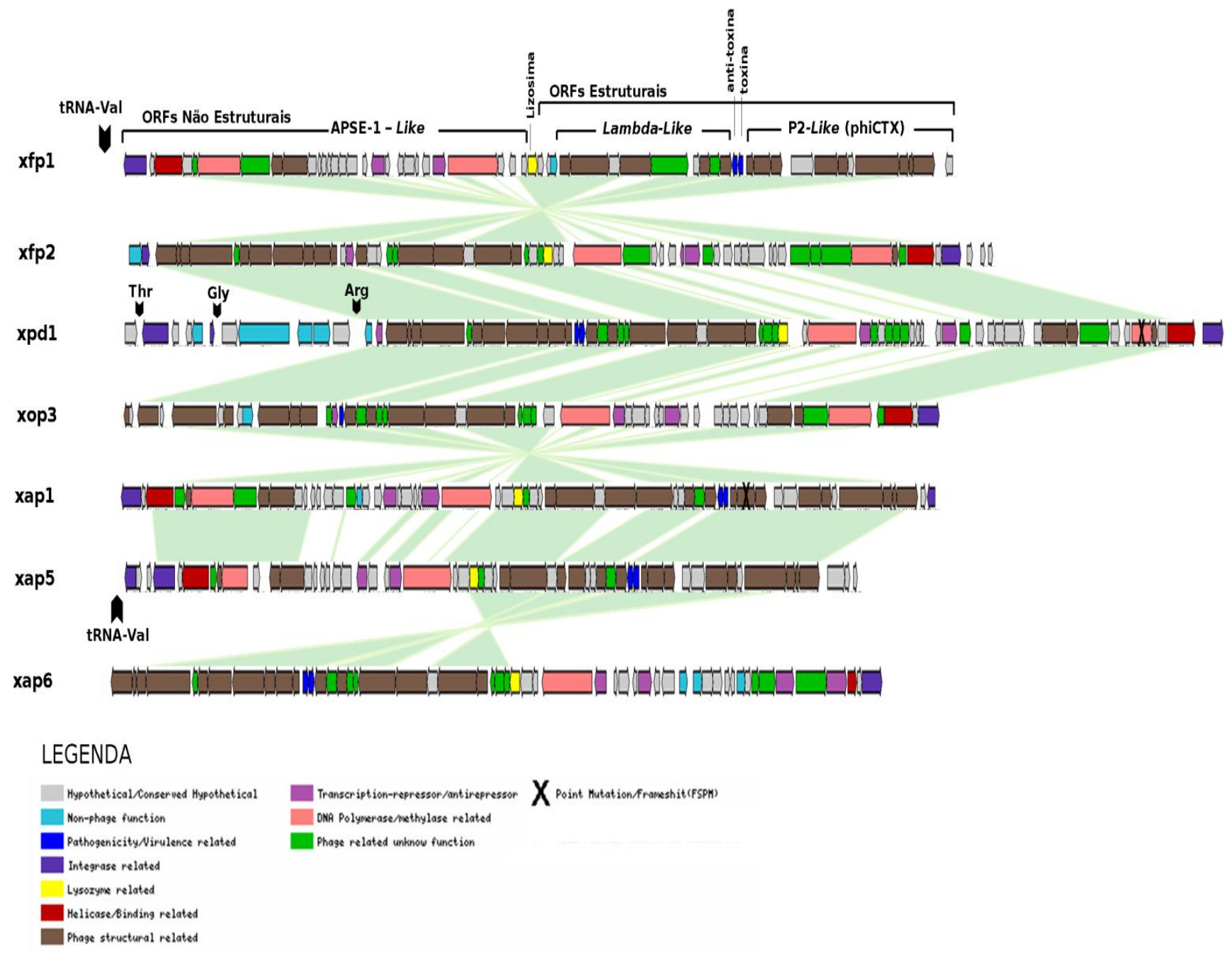

Figura 4.29. Análise comparativa entre as regiões de profagos que apresentam similaridade acima de $70 \%$ com cobertura de no mínimo $80 \%$ de sua sequiência de nucleotídeos (xfp1, xfp2, xdp1, xop3, xap1 e xap5 e região com genes estruturais de xap6). Esquema em forma de mapas genômicos; as cores de cada ORF representam categorização funcional indicada na legenda, e as barras em verde claro representam as regiões que apresentam similaridade de nucleotídeos acima de $70 \%$.

(3) xfp6, xop6 e xap8 apresentam até 64\% de suas seqüências com similaridade acima de 70\%. Uma ORF com provável produto relacionado à virulência está localizada entre a porção de ORFs estruturais e a porção de ORFs não estruturais, sendo que não foi possível estabelecer relação destas regiões frente ao genoma de fagos disponíveis nos bancos de dados (Figura 4.31). A região xop6 apresenta duas integrases, enquanto xfp6 apresenta uma e xap8 não apresenta integrase. Estas regiões também carregam ORFs com produtos não relacionados a fago, provavelmente adquiridas por transferência horizontal mediada pelo fago, tais como uma fimbrilina do tipo IV nas três regiões e transposase relacionada a elementos de inserção (família IS200/IS605) em xfp6 e xap8. 


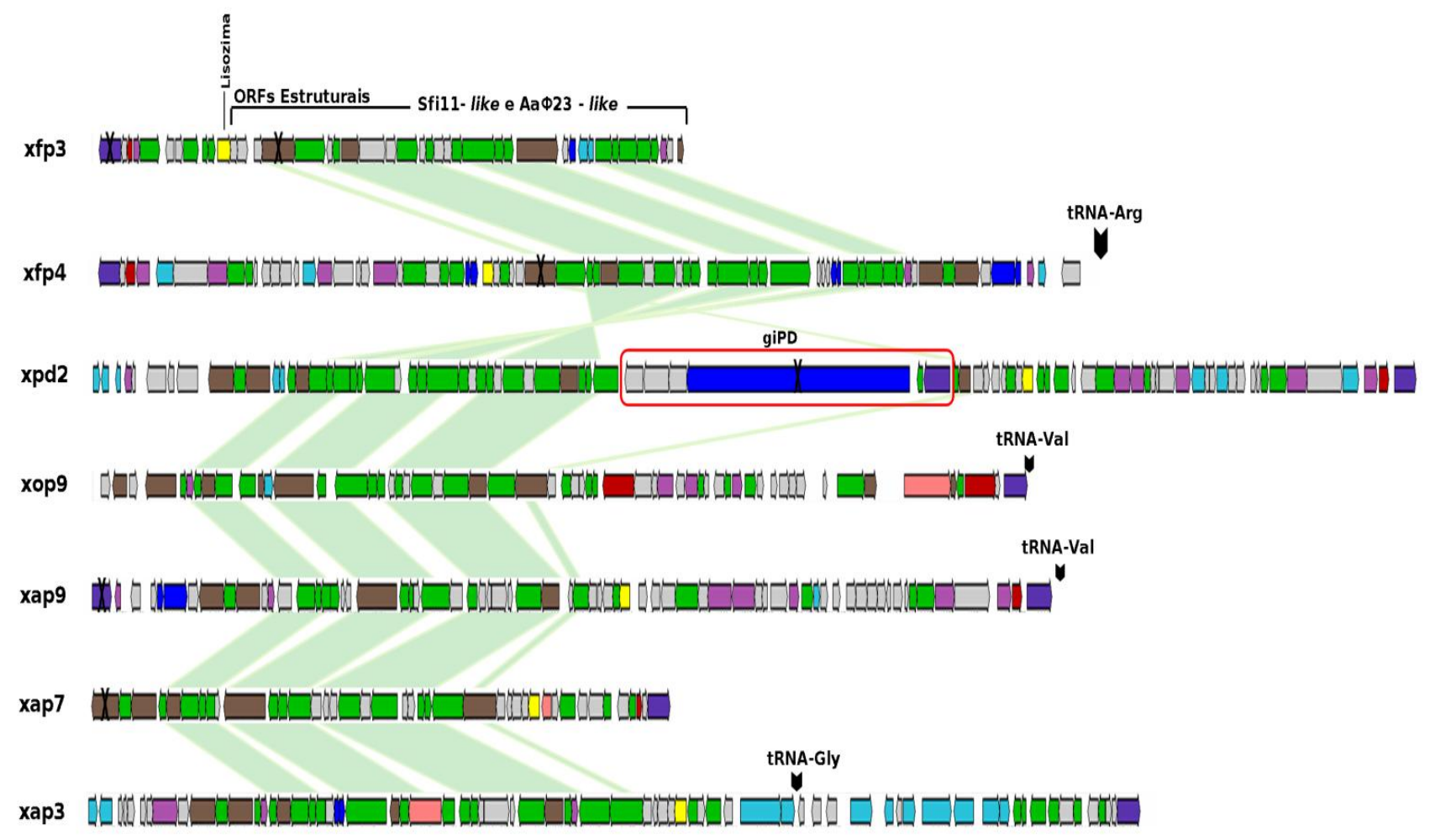

Figura 4.30. Análise comparativa entre as regiões de profagos que apresentam similaridade acima de $70 \%$ apenas na porção referente às ORFs estruturais de fagos. Esquema em forma de mapas genômicos; as cores de cada ORF representam categorização funcional indicada na legenda, e as barras em verde claro representam as regiões que apresentam similaridade de nucleotídeos acima de $70 \%$.
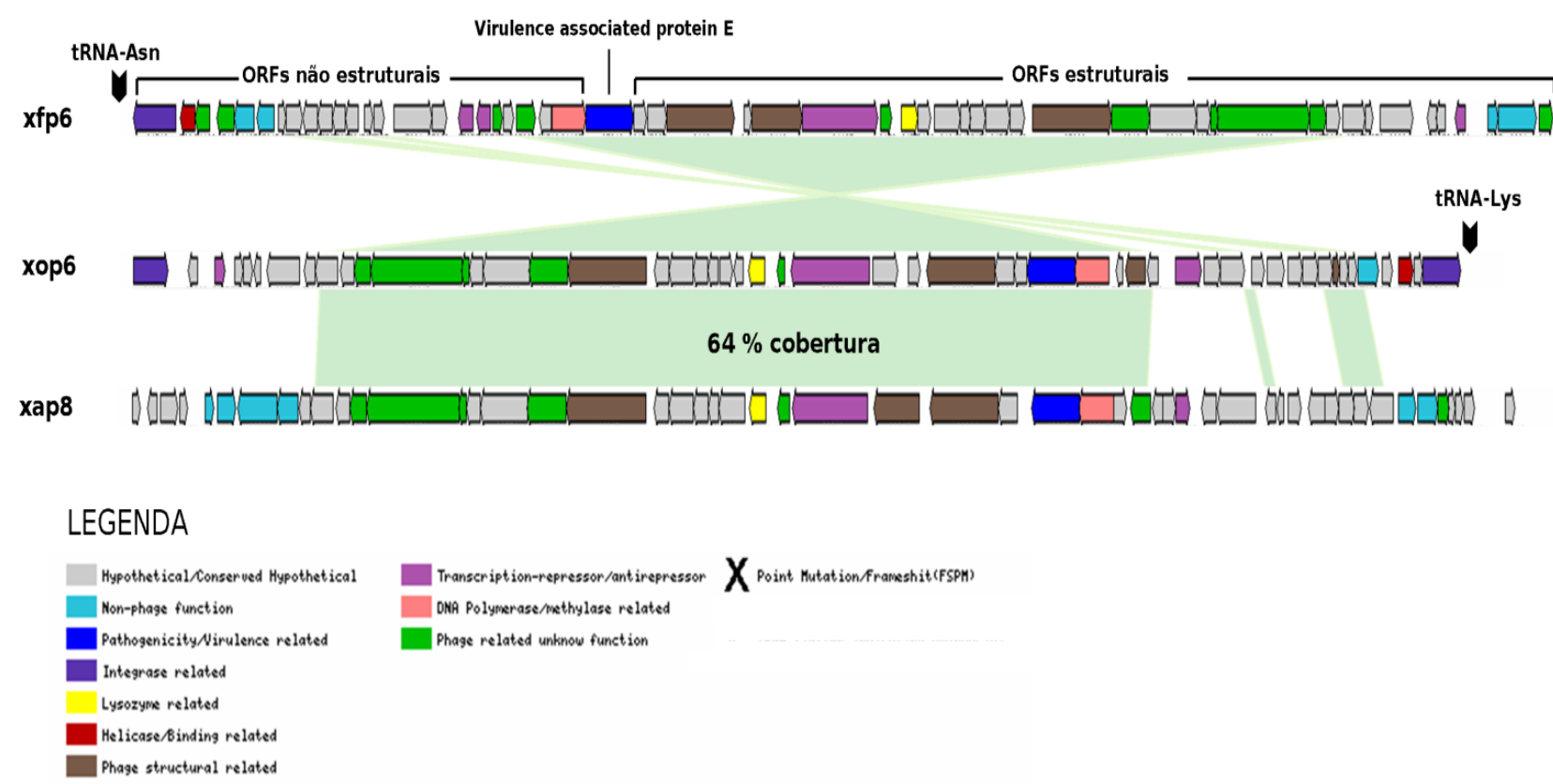

Figura 4.31. Análise comparativa entre as regiões de profagos que apresentam similaridade acima de $70 \%$ ao longo de pelo menos 64\% de sua sequiência. Esquema em forma de mapas genômicos; as cores de cada ORF representam categorização funcional indicada na legenda, e as barras em verde claro representam as regiões que apresentam similaridade de nucleotídeos acima de $70 \%$. 
(4) xfp5, xap4 apresentam pelo menos 35\% de suas seqüências com similaridade acima de $70 \%$, e sua principal característica é que ambas as regiões carregam ORFs com provável produto relacionado à virulência (virulence associated protein). Ambas são regiões degeneradas e aparentemente são profagos defectivos, onde xfp5 apresenta integrase com FS, enquanto xap4 possui duas integrases.

Finalmente, não é possível estabelecer correlação em termos de organização genômica e contexto de inserção entre as demais regiões que não foram abordadas (cvc-r2, pd-r2, xop2, xop4, xop5, xop8 e xap10). Porém, como todas também estão relacionadas a rearranjos, sugerese que estas regiões sejam provenientes de inserções posteriores ao evento de diferenciação entre as linhagens. As regiões cvc-r2 e pd-r2 são regiões pequenas que apresentam até 1.000 pb e são formadas apenas pela integrase ("cicatriz" de evento de inserção), e ambas delimitam rearranjos genômicos. Também não foi possível identificar regiões totalmente exclusivas, pois sempre há compartilhamento de ORFs por BBHs entre todas as regiões, com limitado número de ORFs específicas, conforme abordado no tópico 4.7. Ao menos $80 \%$ das ORFs de cada região relacionada a profagos apresenta pelo menos $15 \mathrm{BBHs}$ (para cada ORF da região) com ORFs presentes em genomas de fagos depositados nos bancos de dados, sugerindo mais uma vez que as regiões de profagos identificadas nas quatro linhagens de Xf estudadas apresentam constituição híbrida e/ou de mosaicos genéticos.

Longas repetições presentes em um mesmo genoma podem parear e permitir que o mecanismo de recombinação homóloga provoque rearranjos genômicos (Canchaya et al., 2003); portanto, as regiões de profagos que apresentam similaridade e identidade de seqüência e que estão contidas na mesma linhagem ([xfp1 e xfp2], [xfp3 e xfp4] em Xf-CVC, e [xap1, xap5 e xap6]; [xap3, xap7 e xap9] em Xf-AL) podem atuar como sítios de recombinação e provocar mudanças abruptas na organização genômica. É importante notar que estas duas linhagens apresentam maior número de rearranjos genômicos quando comparadas entre elas e entre as demais linhagens, e que Xf-PD e Xf-OL não apresentam regiões de profagos com grandes repetições de seqüência e também são as regiões que apresentam menor número de rearranjos quando comparadas com as demais. 


\section{DISCUSSÃO}

Estudos recentes de metagenômica nos oceanos revelam que partículas virais livres no ambiente terrestre constituem um dos maiores reservatórios gênicos passíveis de transferência horizontal entre células vivas (Angly et al., 2006). O objetivo do presente trabalho foi de estudar as integrases e suas regiões vizinhas nos genomas de quatro linhagens de Xylella fastidiosa. Pretendeu-se diferenciar as regiões similares a profagos íntegros de regiões de profagos que apresentam evidências de decaimento, e distinguir estas regiões de ilhas genômicas (IGs). A avaliação da evolução estrutural destas regiões através de estudos de genômica comparativa permitiu a identificação de eventos de inserção ancestral à divergência das linhagens, a análise da dinâmica de diferenciação destas regiões entre as linhagens e a proposição da atividade recente de invasão de bacteriófagos (Anexo V).

\subsection{ASSOCIAÇÃO DOS FAGOS E IGs NA EVOLUÇÃO ESTRUTURAL DO CROMOSSOMO DE XYLELLA FASTIDIOSA}

O processo de evolução pode ser estudado em diferentes escalas temporais, considerando-se curtos e longos prazos evolutivos. Em curto prazo, as modificações afetam apenas o organismo e a população. A longo prazo, modificações afetariam populações inteiras, levando ao desenvolvimento de novas linhagens. Apesar dos diferentes efeitos obtidos nessas duas escalas temporais, os mecanismos moleculares envolvidos são os mesmos: transferência gênica lateral, deleções genômicas, rearranjos genômicos e mutações pontuais. Estes mecanismos atuam no processo evolutivo, tanto em microorganismos patogênicos como nãopatogênicos (Hacker et al., 2004; Pallen e Wren, 2007).

Duas classes gerais de mecanismos podem explicar a diversidade genética que é vista no mundo bacteriano: (i) modificações intra-genômicas, como variações derivadas da divergência e transmissão vertical dos genes existentes, que decorrem do acúmulo de mutações, eventos de inserção/deleção, mutações pontuais e eventos de recombinação (Milkman, 1997; Whittam, 1998) e (ii) aquisição de conjuntos de genes específicos de outros organismos, através de processos de transferência gênica lateral (Lawrence e Roth, 1996; Pallen e Wren, 2007; Syvanen, 1994).

Eventos de transferência lateral podem ser mediados pela inserção de um fago ou uma IG em um genoma bacteriano, e essas regiões podem eventualmente carregar certos atributos de 
patogenicidade, como, por exemplo, determinantes de toxicidade, assim como é observado em Clostridium difficile (Pallen e Wren, 2007), E. coli 0157:H7 (Perna et al., 2001) e Yersinia pestis (Parkhill et al., 2001). Ao longo do tempo, ocorrem modificações estruturais; no caso dos profagos a perda da capacidade de mobilização, tornando-o estável no genoma. A conseqüente expressão de seus atributos de patogenicidade pela bactéria pode permitir a ocupação de um novo nicho, ou a colonização de um novo hospedeiro (Hacker et al., 2004; Pallen e Wren, 2007). Os processos de transferência gênica lateral resultam em modificações abruptas na estrutura, organização e composição dos genomas, sendo capazes de gerar novas linhagens bacterianas (Strauss e Falkow, 1997).

Processos de decaimento e deleções genômicas podem, ao longo do tempo, levar ao desenvolvimento de parasitas intracelulares ou restritos a um determinado ambiente. As deleções genômicas são uma característica comum e constante dos parasitas intracelulares obrigatórios, especialmente em conjuntos de genes potencialmente dispensáveis, durante a adaptação do organismo a diferentes nichos (Sakharkar et al., 2004). Deleções genômicas com possível efeito de desenvolvimento de patógenos intracelulares são observadas em linhagens de Rickettsia prowazekii, Chlamydia trachomatis (Zomorodipour e Andersson, 1999) e Mycobacterium leprae (Cole et al., 2001). Recentemente, observou-se que Leifsonia xyli subs. xyli, que assim como Xf é um patógeno de plantas que infecta o xilema vegetal, apresenta decaimento genômico e que este fenômeno poderia ser o agente responsável pela adaptação do estilo de vida dessa bactéria (Monteiro-Vitorello et al., 2004).

Mutações pontuais levam a mudanças contínuas, mas lentas, dos genes existentes, permitindo uma expansão gradual de nicho e, em uma escala de tempo maior, sendo responsável pela diversificação e especiação dos microorganismos (Strauss e Falkow, 1997). Ambos,

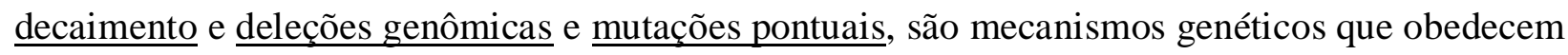
à teoria da evolução proposta por Charles Darwin, onde é assumido que a evolução das espécies é um processo lento decorrente de vários pequenos passos. Ou seja, são processos que podem desencadear mudanças genômicas no decorrer de um longo prazo de tempo, ao contrário do mecanismo de TGL, que ocasiona mudanças genômicas de forma abrupta, sendo que na literatura é citado o termo "salto quântico" para descrição dessas mudanças abruptas (Gal-Mor e Finlay, 2006; Groisman e Ochman, 1996).

Os resultados obtidos no presente trabalho refinam observações prévias de que as principais diferenças encontradas entre as linhagens de Xf estudadas estão associadas à inserção, via mecanismos de TGL, de fagos e IGs no genoma, e tal integração é mediada pelas integrases (Figuras 4.23 e 4.24). A questão que se apresenta é se esse mecanismo genético de TGL seria o possível agente responsável pela diferenciação das linhagens de Xf. 
A favor desta proposta estão os resultados desse trabalho que indicam que, em média, $320 \mathrm{~kb}$ (ou 12\%) do genoma de Xf corresponde a profagos e IGs (Tópico 4.1). Estas regiões de profagos carregam, além dos genes essenciais de bacteriófagos, um conjunto de genes nãoessenciais relacionados a funções não-virais e hipotéticas, que também englobam genes potencialmente relacionados à virulência e patogenicidade (Tópico 4.7) e um número considerável de genes de bacteriófagos, (Figura 4.26). Estas poderiam também atuar como mediadores da especificidade e diferenciação entre as linhagens estudadas. Muitas destas ORFs que apresentam funções não-virais, hipotéticas e hipotéticas conservadas são específicas para determinada linhagem, mesmo quando comparadas contra 402 genomas de fagos por metodologia de BBH (Tabela 5.1), sugerindo que poderiam ser produtos diretos de processos de transdução generalizada e/ou especializada.

O fato de haver alterações mínimas no número de ORFs específicas nas regiões de profagos de $\mathrm{Xf}$, quando se compara (por metodologia de $\mathrm{BBH}$ ) somente as quatro linhagens ou quando se compara as quatro linhagens com 402 genomas de fagos (Tabela 5.1) pode indicar que: (i) estas ORFs a princípio não estariam relacionadas a funções virais conhecidas, pois não apresentam BBHs com ORFs dos genomas de 402 fagos, e que (ii) as ORFs poderiam estar relacionadas diretamente a funções responsáveis pela virulência da bactéria, como por exemplo a especificidade a diferentes hospedeiros. Outra evidência para a questão proposta está relacionada ao próprio processo de TGL por fagos que afeta Xf, onde os mesmos poderiam desempenhar importante papel no contexto de diferenciação das linhagens através de alterações genômicas abruptas.

Brussow e colaboradores (2004) afirmam que os genomas de fagos e de bactérias evoluem em conjunto, sendo que os profagos podem contribuir para a diversificação da arquitetura genômica de bactérias. Assim, a primeira proposta levantada por esse trabalho é a de que os fagos desempenham papel importante na evolução genômica no gênero Xylella: sua atuação no mecanismo de transdução, carregando genes de virulência e promovendo grandes rearranjos genômicos (Tópicos 4.6 e 4.7), os torna possíveis agentes responsáveis pela diversificação da organização genômica. Tal diversificação pode levar à diferenciação de novas linhagens mais virulentas e/ou com habilidade de colonizar e se adaptar a novos hospedeiros e condições ambientais, de forma similar ao que é observado devido à ação de fagos e IGs presentes em diversas linhagens enteropatogênicas de E. coli, Shiguella flexneri, Salmonella enterica sv Typhi, Salmonella enterica sv Typhimurium, Yersinia pestis, Streptococcus pyogenes, Vibrio cholerae e Staphylococcus aureus (Hacker et al., 2004; Pallen e Wren, 2007). 
Tabela 5.1. Número de ORFs específicas para cada linhagem e a qual região relacionada a fago pertence.

\begin{tabular}{|c|c|c|}
\hline Região de profago & $\mathbf{A}$ & B \\
\hline xfp1 & 9 & 9 \\
\hline $\mathrm{xfp} 2$ & 8 & 8 \\
\hline xfp3 & 4 & 4 \\
\hline $\mathrm{xfp} 4$ & 2 & 2 \\
\hline xfp5 & 11 & $10(*)$ \\
\hline xfp6 & 3 & 3 \\
\hline cve-r1 & 2 & 2 \\
\hline cve-r2 & 0 & 0 \\
\hline cve-r3 & 8 & 8 \\
\hline cve-r4 & 3 & $2(*)$ \\
\hline cve-r5 & 9 & $7(*)$ \\
\hline giCVC & 75 & $68(*)$ \\
\hline xpd1 & 11 & 11 \\
\hline xdp2 (giPD) & 17 & $16(*)$ \\
\hline $\mathrm{xpd} 3$ & 3 & 3 \\
\hline xdp4 & 1 & 1 \\
\hline xpd5 & 20 & $17(*)$ \\
\hline xpd6 & 7 & 7 \\
\hline xpd7 & 1 & 1 \\
\hline xpd8 & 7 & 7 \\
\hline pd-r1 & 1 & 1 \\
\hline pd-r2 & 0 & 0 \\
\hline xop1 & 1 & 1 \\
\hline xop2 & 9 & $8(*)$ \\
\hline xop3 & 8 & 8 \\
\hline xop4 & 9 & 9 \\
\hline xop5 & 14 & $13(*)$ \\
\hline xop6 & 7 & 7 \\
\hline xop7 & 26 & $23(*)$ \\
\hline xop8 & 28 & $27(*)$ \\
\hline xop9 & 12 & $9(*)$ \\
\hline xop10 & 19 & $18(*)$ \\
\hline ol-r1 & 0 & 0 \\
\hline xap1 & 1 & 1 \\
\hline xap2 & 11 & 11 \\
\hline xap3 & 6 & 6 \\
\hline xap4 & 5 & $4(*)$ \\
\hline xap5 & 10 & 10 \\
\hline xap6 & 2 & 2 \\
\hline xap7 & 4 & 4 \\
\hline xap8 & 9 & 9 \\
\hline xap9 & 12 & $11(*)$ \\
\hline xap10 & 19 & $13(*)$ \\
\hline xap11 & 0 & 0 \\
\hline al-r1 & 0 & 0 \\
\hline al-r2 & 3 & 3 \\
\hline al-r3 & 4 & 4 \\
\hline
\end{tabular}

(A) ORFs que não agrupam em BBHs somente quando comparadas entre as quatro linhagens de Xf. (B) ORFs que não agrupam em BBHs quando comparadas com as ORFs de 402 genomas de fagos.

Fonte: http://gracilaria.ib.usp.br/integraseDB/services/comp-table.html

Nota: Asteriscos indicam existência de diferenças entre as coluns A e B. 
Proteínas com atividade integrase são essenciais para o processo de inserção de fagos e ilhas genômicas em cromossomos bacterianos. O estudo da relação filogenética entre as integrases encontradas no genoma das linhagens de Xf permitiu verificar que: (i) linhagens distintas de bacteriófagos são agentes infecciosos efetivos em Xf; (ii) que Xf é permissiva a infecção por bacteriófagos, pertencentes a clados evolutivos distintos.

\subsection{DIVERSIDADE DAS INTEGRASES: SÍTIOS DE INSERÇÃO E EGMs ASSOCIADOS}

\subsubsection{Integrases de Fagos}

Há uma variedade de integrases no genoma das quatro linhagens de Xf: integrases completas, apresentando SCF/FS e fragmentos, em associação ou não com tRNAs (como sítios preferenciais de inserção), mas sempre relacionadas a profagos ou a regiões remanescentes (Tabela 4.1), sendo o universo dessas regiões de profagos bastante distinto em termos de conteúdo de suas ORFs e de seqüências de nucleotídeos (Tópico 4.7).

Nota-se, como apresentado na tabela 5.2, que dentro do universo de genomas estudados há uma correlação entre integrases potencialmente funcionais/completas e regiões passíveis de representar um profago íntegro. As integrases que apresentam FS/SCF estão preferencialmente associadas a regiões relacionadas afagos que apresentam tamanho médio de $17 \mathrm{~kb}$. Por outro lado, as integrases completas estão majoritariamente presentes nas maiores regiões de profagos, sendo que algumas destas regiões foram classificadas como prováveis fagos completos (Tabela $5.2)$.

Tabela 5.2: Correlação entre as formas de integrases identificadas em Xf e suas respectivas regiões de profagos *.

\begin{tabular}{|c|c|c|}
\hline Integrases & Regiões de profagos & Tamanho médio \\
\hline Completas & 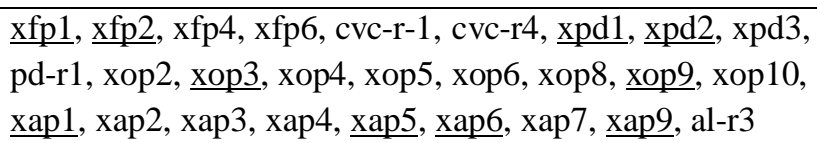 & $34 \mathrm{~kb}$ \\
\hline Com FS/SCF & xfp3, xfp5, xpd6, xpd7, xpd8, ol-r1, al-r2 & $17 \mathrm{~kb}$ \\
\hline Fragmentos & cvc-r2, cvc-r3, pd-r2, xap10, xap11, al-r1 & $7,5 \mathrm{~kb}$ \\
\hline
\end{tabular}

* Em destaque, regiões consideradas fagos completos. 
Segundo Brussow e colaboradores (2004), os profagos parecem ser os únicos passageiros transientes nos genomas bacterianos, ao menos em termos evolutivos. Argumentos teóricos sugerem que uma série de eventos, como acúmulo de mutações e perda massiva de DNA do profago, resultaria no decaimento e posterior desaparecimento dos fagos. Desta forma, os resultados obtidos por esse trabalho (e apresentados de forma resumida na tabela 5.2) sugerem que existe um decaimento das regiões de profagos, diretamente relacionado com a estrutura da integrase. Portanto, uma primeira hipótese é levantada por este trabalho: “As integrases e regiões relacionadas a profagos estariam evoluindo juntas ao longo do tempo em termos de decaimento genômico e existiria uma pressão positiva para extirpação dessas regiões no genoma”.

A favor desta hipótese estão os dados que sugerem que as integrases completas estariam associadas às maiores regiões, correspondendo provavelmente a eventos recentes de inserção; enquanto integrases que apresentam FS/SCF estariam associadas a regiões que estariam em processo de decaimento; e fragmentos de integrases associados às regiões remanescentes de fagos. Esses dados confirmariam a proposta de que regiões de fagos e suas integrases associadas estariam co-evoluindo em termos de decaimento genômico.

Porém, em contrapartida a esta proposta de decaimento e posterior desaparecimento de uma determinada região relacionada a fago, dois pontos devem ser levados em consideração: (i) determinadas regiões carregando ORFs de importância para adaptação e virulência para a bactéria (ver discussão tópico 5.3) poderiam estar sob seleção positiva (para estabilização no genoma); (ii) a indução de um profago ao ciclo lítico, onde processos de transdução generalizada ou especializada poderiam levar a uma extirpação imperfeita do genoma, deixando pedaços desse profago no genoma, que poderiam ser confundidos com as regiões remanescentes que estariam sofrendo o decaimento (Tópico 1.1.2 e figura 1.7). Portanto, apesar de haver evidências que suportam esta proposta, as alternativas acima mencionadas merecem ser consideradas.

Por outro lado, pode-se considerar que a diferenciação de Xylella seja bastante recente e decorrente de eventos recorrentes e massivos de infecção viral. A presença de profagos íntegros contrapõe-se à noção de decaimento. Talvez o decaimento fosse iniciado muito rapidamente. Infelizmente, estas hipóteses não podem ser testadas pelas estratégias aqui utilizadas.

Além de serem encontradas em formas diferentes, conforme discutido acima, as integrases também apresentam diferenças na organização de sua seqüência primária de aminoácidos. Alinhando-se a seqüência completa de aminoácidos de todas as integrases completas e com FS/SCF (exceto fragmentos) identificadas por este trabalho, foi possível verificar a formação de 5 ramos distintos (Figura 4.3), sendo que praticamente todas apresentam assinatura catalítica característica de tirosinas recombinases (Tópico 4.2 e tabela 4.1). A presença 
exclusiva de integrases pertencentes à essa família no genoma das Xylellas não é um fato totalmente inesperado, uma vez que as serinas recombinases não apresentam a mesma abundância que as tirosinas recombinases em genomas bacterianos (Groth e Calos, 2004; Smith e Thorpe, 2002). Desta forma, este resultado indica que ao menos nestas quatro linhagens a assinatura catalítica de suas integrases está de acordo com o esperado e citado pela literatura.

Porém, qual informação qualitativa poderia ser extraída a partir dos resultados sobre os domínios catalíticos das integrases, onde praticamente apenas tirosinas recombinases foram identificadas?

Um fato marcante está relacionado aos ramos $\mathbf{A}, \mathbf{B}$ e $\mathbf{D}$, onde não foi identificado o resíduo catalítico $\mathrm{H}[308]$ na posição esperada (porém com os demais resíduos presentes), sendo que nas integrases do ramo $\mathbf{C}$ todos os resíduos que configuram a assinatura catalítica da tirosina recombinase de fago estão presentes. A ausência de algum resíduo pertencente à assinatura catalítica das tirosinas recombinases não é um fato incomum: o fago HP1 também não apresenta todos os resíduos catalíticos propostos, como a ausência do resíduo K[225] (Groth e Calos, 2004). Este fato indica que há variações na assinatura catalítica das tirosinas recombinases e que talvez o modelo proposto apresente mais exceções. Portanto, este trabalho caracterizou esta variação de resíduo catalítico nas integrases de Xf.

Dentro do ramo A, aparentemente apenas xfp3_fs não apresentaria atividade catalítica, pois não apresenta a tirosina catalítica Y[342] (Figura 4.5). No ramo B e D, as integrases que apresentam FS/SCF (al_r2_FS xpd6_FS, xpd7_FS e xap9_FS) apresentam todos os resíduos responsáveis pela atividade catalítica, porém aparentemente não são integrases funcionais (Figura 4.6), indicando a possibilidade de estarem contidas em regiões de profagos em processo de decaimento. O ramo $\mathbf{E}$ aparece mais próximo às serinas recombinases modelo (phiC31), porém apresenta todas os resíduos catalíticos para ser caracterizado como tirosinas recombinases (Figuras 4.9 e 4.10). Considerando a proximidade filogenética de Xf com o gênero Xanthomonas, cabe ressaltar que apenas o ramo $\mathbf{E}$ das integrases preserva essa relação. Este resultado sugere que as integrases pertencentes a este ramo poderiam estar presentes no ancestral comum ou que estas linhagens bacterianas compartilham do nicho ocupado por este bacteriófago (Tópico 4.2).

Além da caracterização da assinatura das tirosinas recombinases, foi possível determinar os diversos sítios preferenciais de inserção das integrases associados a tRNAs (Tópico 4.5). As integrases de fagos têm sido objeto de estudo ao longo das últimas três décadas, mas a elucidação dos mecanismos pelos quais elas reconhecem o DNA está apenas no começo. Durante milhões de anos de evolução, os fagos se diversificaram muito, e atualmente é difícil 
detectar as relações evolutivas entre as diferentes integrases e suas seqüências de reconhecimento (att). DNA e proteína evoluíram em conjunto, e uma integrase é capaz de reconhecer seus próprios sítios att, mas não os sítios de outra integrase de fago similar. Isso é observado, por exemplo, entre os fagos lambda e HK022, entidades próximas filogeneticamente: suas integrases apresentam $70 \%$ de similaridade entre suas seqüências de aminoácidos, e ambas apresentam o mesmo sítio attP; no entanto, nenhuma delas pode recombinar com os sítios att $\mathrm{B}$ da outra (Groth e Calos, 2004). Este fato demonstra que a conservação da estrutura primária, e por conseqüência a conservação da estrutura terciária de uma integrase, não pode ser usada como indicativo de mesma especificidade por determinado sítio de reconhecimento no DNA entre duas integrases similares. Aparentemente, integrases semelhantes entre linhagens diferentes de Xf apresentam sítios de inserção distintos no genoma (Tópico 4.5), assim como também é observado para as integrases de lambda e HK022.

Segundo Williams (2002), as integrases utilizam tRNAs como sítios de reconhecimento para inserção de EGMs, sendo que de um grupo de 58 integrases da família das tirosinas recombinases presentes em genomas de organismos procariontes, 34 (59\%) utilizam tRNA como sítio de reconhecimento no genoma da bactéria (attB). Em outro estudo, Hacker e Kaper (2000) afirmam que integrases de ilhas genômicas utilizam tRNAs como att $\mathrm{B}$ em pelo menos $75 \%$ dos casos. Por fim, segundo a literatura, os tRNAs [GLU, GLN, HIS, MET e TRP], por algum motivo ainda não determinado, são impróprios para utilização como attB pelos EGMs (Williams et al., 2002). Em Xf não é diferente, pois foi possível identificar que $71 \%$ dos sítios de inserção de regiões de profagos e IGs, onde as integrases estão contidas, estão localizados ao lado de tRNAs, relacionados a 8 tipos [VAL, ARG, CYS, ASN, GLY, SER, LYS e THR], sendo nenhum deles considerado impróprio segundo a literatura (Tabelas 4.8 e 4.9).

Conforme abordado no tópico 4.5, alguns dos tRNAs utilizados como sítios de inserção apresentam-se na borda de uma região de fago, sendo que um pedaço deste mesmo tRNA também está presente na outra borda da mesma região de profago (Figura 4.20); em outros casos, é observado apenas um pedaço do tRNA ao lado de uma região de profago, sugerindo que a inserção também pode inviabilizar o tRNA da bactéria que foi utilizado como sítio de inserção (Figura 4.21). Porém, é possível elaborar um modelo sobre como ocorreu a inserção destes profagos, onde é possível observar a inviabilização do tRNA da bactéria ?

$\mathrm{Na}$ tentativa de responder a estas duas perguntas, foram elaboradas duas propostas, que estão apresentadas nas figuras 5.1 e 5.2, ilustrando um provável modelo de integração para estes dois casos. Os esquemas apresentados ilustram o tRNA sendo utilizado como sítio de inserção que pode ser reconstituído (Figura 5.1) ou inviabilizado (Figura 5.2), de acordo o que já foi 
citado na literatura para outros microorganismos (Williams, 2002) e evidenciado pela primeira vez em Xf por este estudo.

Há quatro cópias do tRNA-GLY para cada linhagem, e elas usam três diferentes anticódons [2x GCC, CCC e TCC]. Uma cópia do tRNA-GLY[GCC] está presente dentro da região de profago e a outra cópia dispersa no cromossomo. Em Xf-CVC, uma cópia do tRNAGLY[GCC] encontra-se dentro da região cvc-r4 e outra está ao lado da giCVC. Nas demais linhagens, a cópia do tRNA-GLY[GCC] que não se encontra na região de profago não está associada a nenhum outro EGM. Um fato importante, observado em Xf-CVC, aponta que o tRNA-GLY[GCC] que está ao lado da giCVC apresenta cove score menor, quando comparado aos respectivos tRNAs-GLY[GCC] das outras linhagens que não estão associados a EGMs (Tabela 5.3). O valor de cove score está relacionado com a probabilidade de acurácia na detecção baseado em predições de estrutura secundária de tRNA pelo programa tRNAscan-SE (Lowe e Eddy, 1997). A figura 5.3 ilustra o alinhamento e a predição da estrutura secundária deste tRNAGLY[GCC], onde é notável que a cópia de Xf-CVC (vizinha a giCVC) apresenta diferenças de seqüência e estruturais.

Conforme citado anteriormente, eventos de integração também podem danificar o tRNA utilizado como sítio de inserção, podendo tornar este tRNA não funcional e eventualmente tornar a excisão deste elemento menos favorável (Williams et al., 2002). Com base nas evidências apresentadas, sugere-se que a inserção de giCVC foi responsável pelas alterações nas estruturas primária e secundária do tRNA-GLY [GCC].

Tabela 5.3. Anti-códons do tRNA-GLY encontrado no genoma de Xf. Os números representam o cove score.

\begin{tabular}{l|c|c|c|c}
\hline Anti-códon & Xf-CVC & Xf-PD & Xf-OL & Xf-AL \\
\hline GCC (profago) & 92 & 92 & 92 & 92 \\
GCC & $\mathbf{6 3}(*)$ & 92 & 92 & 92 \\
CCC & 79 & 79 & 79 & 79 \\
TCC & 80 & 80 & 80 & 80 \\
\hline
\end{tabular}

(*) Sítio de inserção para giCVC. Esse anti-códon GCC de Xf-CVC apresenta score abaixo da média dos demais. 


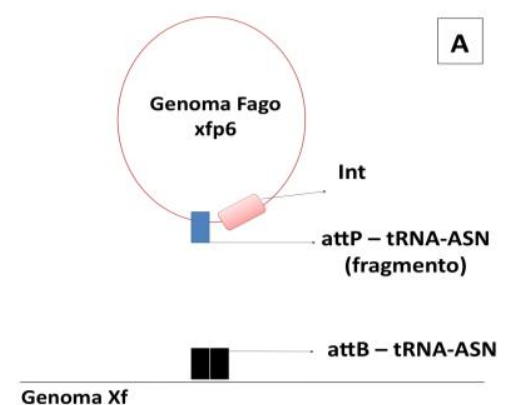

C

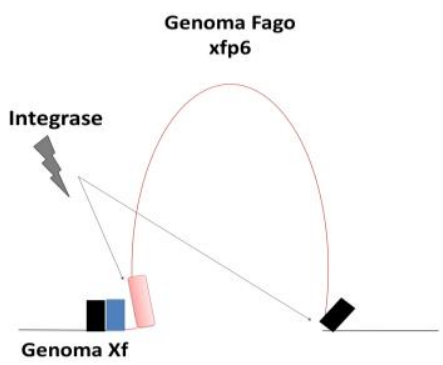

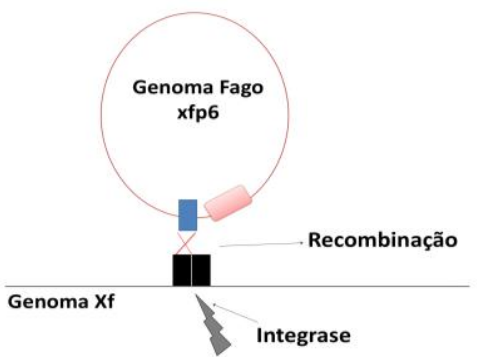

D

Genoma Fago xfp6 - Integrado

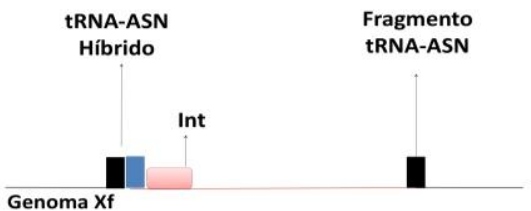

Figura 5.1. Hipótese de quebra com reconstituição do tRNA-ASN. Exemplo formulado a partir do fago xfp6; este modelo também pode ser aplicado para a região xap9 (tRNA-VAL). A, o fago xfp6 invade o genoma de Xf-CVC, B, Reconhecimento (pareamento) entre os sítios att $\mathrm{B}$ e $\operatorname{att} \mathrm{P}$, seguindo pela ação enzimática da integrase. C, A integrase realiza a quebra da molécula de DNA do fago e da bactéria e realiza a re-ligação, provocando a quebra do tRNA da bactéria em duas porções, sendo que a primeira porção é reconstituída pela fração do attP que estava presente no genoma do fago e a segunda porção do tRNA da bactéria permanece no outro lado do ponto de inserção de fago. D, Genoma do profago inserido no genoma de Xf-CVC.
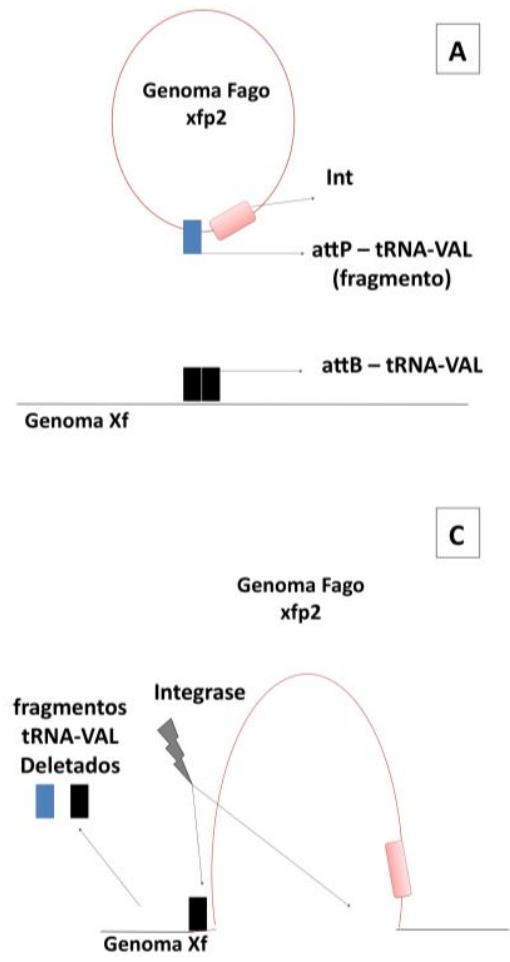

C

A

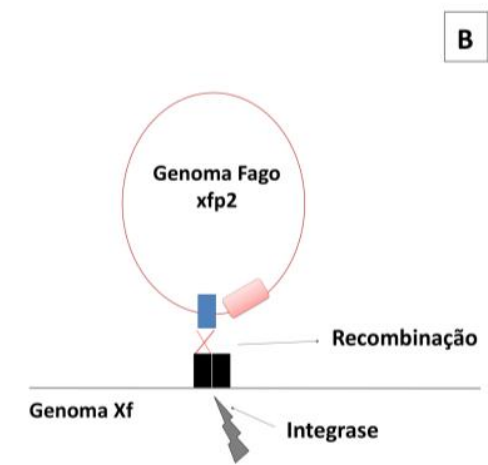

D

Genoma Fago xfp2 - Integrado

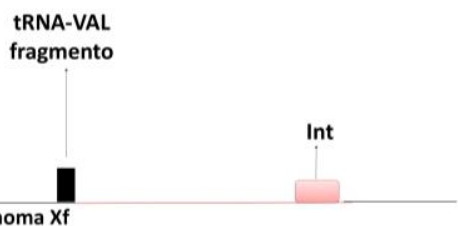

Figura 5.2. Hipótese da quebra com inviabilização do tRNA-VAL. Exemplo formulado a partir do fago xfp2; este modelo também pode ser aplicado para as regiões xap1 (tRNA-VAL), xap4 (tRNA-ASN) e xap10 (tRNA-LYS). A, o fago xfp2 invade o genoma de Xf-CVC; B, Reconhecimento (pareamento) entre os sítios attB e attP, seguindo pela ação enzimática da integrase; $\mathbf{C}$, A integrase realiza a quebra da molécula de DNA do fago e da bactéria e realiza a re-ligação, provocando a quebra do tRNA da bactéria, sendo que no momento da inserção do genoma do fago não ocorre reconstituição do tRNA; D, Genoma do profago inserido no genoma de Xf-CVC. 


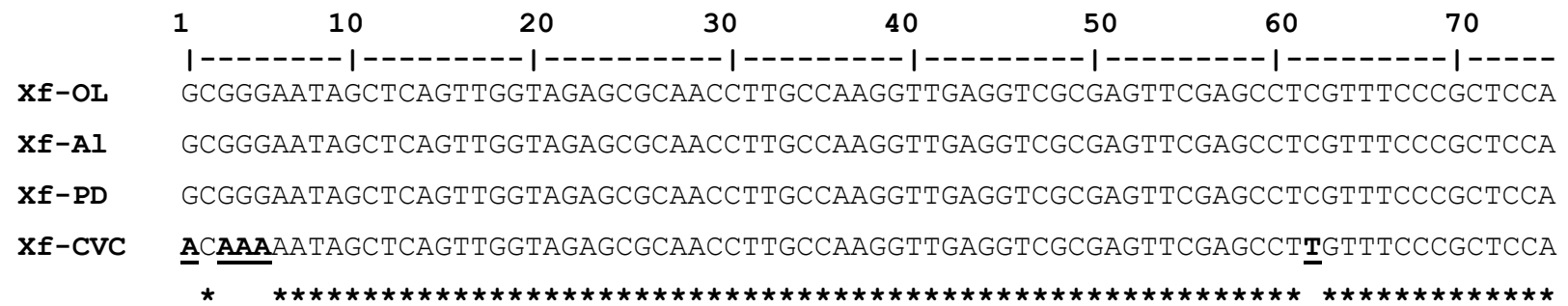

U

B

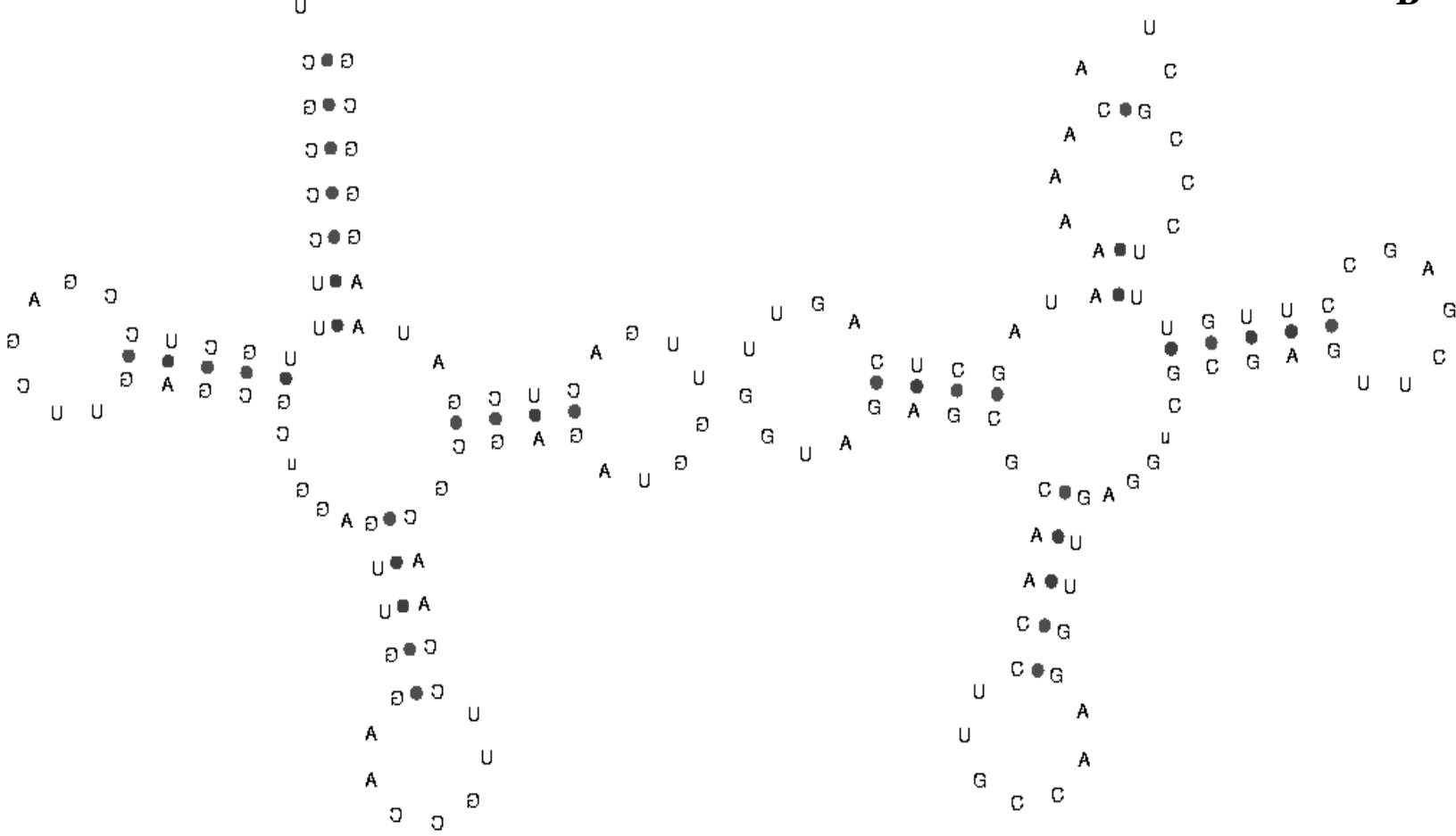

Xf-PD / Xf-OL / Xf-AL

Xf-CVC

Figura 5.3. Estrutura primária (A) e secundária (B) do tRNA-GLY [GCC] não relacionado a EGMs (exceto em XfCVC, relacionado com giCVC).

Por outro lado, os resultados também sugerem que o tRNA-GLY[GCC] que está contido dentro das regiões de profagos cvc-r4, xpd6, xop10 e xap3 possa ter sido adquirido pelo próprio evento de transdução ocasionado pela invasão do fago (Tópico 4.5 e Figura 4.22). Quais evidências dão suporte a esta hipótese? Uma evidência está relacionada à própria informação presente nos genomas dos fagos depositados no NCBI, onde ao menos 81 (19\%) de um total de 430 fagos carregam tRNAs completos em seu genoma (391 tRNAs), incluindo um grupo de fagos que também carrega tRNA-GLY (a figura 5.4 apresenta uma análise do tRNA-Scan em 430 genomas de fagos). No total, 21 cópias de tRNA-GLY estão presentes ao longo do genoma de 18 fagos, sendo que quatro destes fagos apresentam BBHs com as integrases de Xf (regiões cvc-r4, xpd6, xop10 e xap3, as mesmas que contém um tRNA-GLY interno) (Tabela 5.4), e todos são da família Siphoviridae, que aparentemente é a família mais prevalente em Xf (Tópico 4.7). 


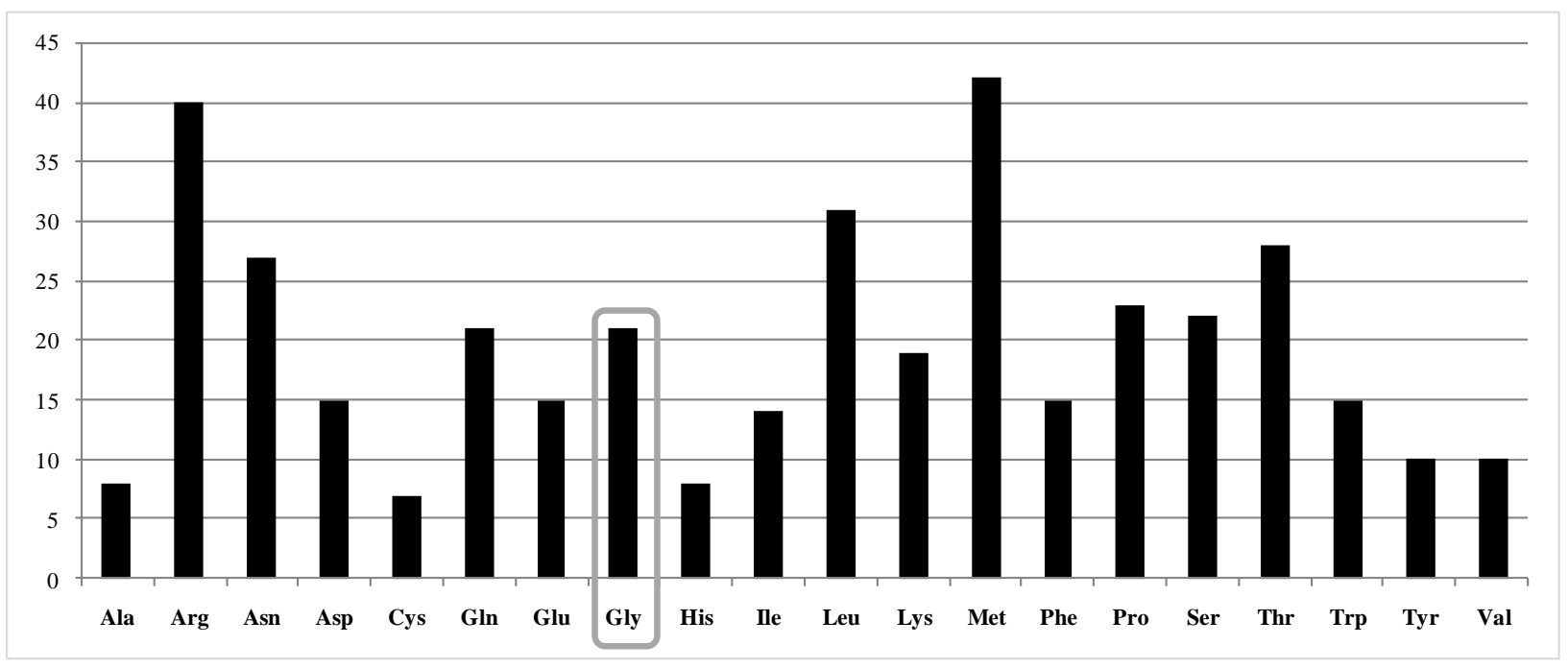

Figura 5.4. Distribuição dos tRNAs identificados em 81 dos 430 genomas de fagos depositados no NCBI. Destaque para a ocorrência do tRNA-GLY.

Tabela 5.4. Lista dos fagos que apresentam tRNA-Gly no genoma.

\begin{tabular}{l|c|l}
\hline \multicolumn{1}{c|}{ Fago } & Número de tRNAs & \multicolumn{1}{c}{ Família } \\
\hline Aeromonas phage 25 & 1 & Myoviridae; T4-like \\
Aeromonas phage Aeh1 & 2 & Myoviridae; T4-like \\
Cyanophage phage S-PM2 & 1 & Myoviridae \\
Enterobacteria phage Felix 01 & 1 & Myoviridae \\
Enterobacteria phage RB32 & 1 & Myoviridae; T4-like \\
Enterobacteria phage T4 & 1 & Myoviridae; T4-like \\
Enterobacteria phage T5 & 1 & Siphoviridae; T5-like \\
Lactobacillus phage LP65 & 1 & Myoviridae; SPO1-like \\
Lactobacillus phage phig1e & 1 & Siphoviridae \\
Listeria phage P100 & 1 & Myoviridae \\
Mycobacterium phage 244 (*) & 1 & Siphoviridae \\
Mycobacterium phage Bxz1 & 2 & Myoviridae \\
Mycobacterium phage Catera & 2 & Myoviridae \\
Mycobacterium phage Cjw1 $(*)$ & 1 & Siphoviridae \\
Mycobacterium phage Omega (*) & 1 & Siphoviridae \\
Mycobacterium phage Wildcat & 1 & Siphoviridae \\
Pseudomonas phage D3 $(*)$ & 1 & Siphoviridae \\
Vibrio phage KVP40 & 1 & Myoviridae; T4-like \\
\hline As & &
\end{tabular}

Nota: As integrases dos fagos marcados com (*) estão no mesmo grupo de BBHs das integrases de cvc-r4, xpd6, xop10 e xap3, regiões em Xf contendo tRNA-GLY interno.

Os dados apresentados no tópico 4.5 e figura 4.22 são um forte indicativo de que os fagos podem carregar tRNAs completos em seu genoma e, sendo esses fagos entidades ativas, capazes de infectar bactérias, os mesmos poderiam disponibilizar tRNAs para as bactérias susceptíveis, quando inseridos no genoma na forma de profago. Com base nestas evidências, 
sugere-se que aparentemente os elementos cvc-r4, xpd6, xop10 e xap3 foram responsáveis pela aquisição de um tRNA-GLY variante no genoma de Xf, por mecanismos de transferência lateral.

\subsubsection{Integrases de Ilhas Genômicas}

Foram identificadas apenas duas integrases associadas às IGs nas quatro linhagens de Xf estudadas, sendo que estas integrases já foram previamente descritas, inclusive com seus respectivos sítios de inserção (Van Sluys et al., 2003). O fato de não terem sido identificadas integrases de IGs homólogas a giCVC e giPD nas linhagens Xf-AL e Xf-OL também já era um fato devidamente esperado, visto que estudos anteriores não apontaram evidências da presença de ilhas genômicas similares às encontradas em Xf-CVC e Xf-PD (Van Sluys et al., 2003).

Estas integrases pertencem à família das tirosinas recombinases, mas não possuem a mesma assinatura catalítica presente nas integrases de fagos. Além disso, apresentam o domínio CP4-like (Figura 4.11), estando próximas a integrases pertencentes às três famílias de fagos (Siphoviridae, Myoviridae e Podoviridae) (Figura 4.14).

\subsection{REgiões RELACIONAdAS A PROFAgos E IGs: PROVÁVEL RELAÇÃO COM A VIRULÊNCIA BACTERIANA}

A invasão de bacteriófagos ou ilhas genômicas em um genoma bacteriano pode promover, a longo-prazo, o aparecimento de ilhas de patogenicidade, como sub-produtos da degeneração e decaimento desses profagos e ilhas (Hacker et al., 2004). No entanto, para se configurar como tal, os EGMs introduzidos necessariamente deveriam carregar atributos de patogenicidade e/ou virulência, que seriam mantidos na bactéria por pressão positiva. A pergunta aqui é se os profagos e IGs presentes nas linhagens de Xf podem apresentar papel na virulência e patogenicidade desses fitopatógenos.

Os resultados apresentados nesse trabalho sugerem que os elementos genéticos móveis nas Xf podem apresentar papel importante sim. Um primeiro levantamento nas regiões de profagos mostrou que essas regiões carregam sistemas de toxinas e anti-toxinas. Sistemas toxinaantitoxina são comumente encontrados em plasmídeos, ou em cromossomos bacterianos, onde 
sua função ainda não é completamente elucidada. Um sistema protéico toxina-antitoxina pode ser definido como um elemento genético "aditivo", que codifica duas proteínas intracelulares: uma toxina estável e uma antitoxina instável. A transcrição dos dois genes é tipicamente autoregulada e mantém níveis estáveis de toxinas e antitoxina. Algumas hipóteses sobre sua provável função no genoma dos fagos em que estão presentes são: (i) estabilização do genoma do profago no genoma da bactéria, (ii) regulação da expressão gênica do fago, (iii) controle do crescimento bacteriano em condições de estresse, (iv) ação anti-fago, reprimindo a expressão de genes de fagos (Magnuson, 2007).

Além de toxinas e anti-toxinas, também foram identificadas ORFs que codificam produtos relacionados a processos de virulência (como hemaglutininas, toxinas e virulence proteins) (Tópico 4.7, Tabela 4.12 e Figura 4.26). Desta forma, regiões que apresentam estes genes em sua constituição devem ser consideradas (Tabela 5.5).

Análises de ilhas de patogenicidade (IP) em diversos organismos apontam para similaridade com seqüências de genes de plasmídeos e fagos; portanto, especula-se que as IPs sejam originadas a partir de plasmídeos integrativos ou fagos que perderam genes necessários para sua replicação e mobilização em favor de uma associação mais estável com o genoma hospedeiro (Hacker et al., 2004). Porém, apesar dos mecanismos relacionados à aquisição de plasmídeos e fagos serem muito bem compreendidos e documentados pela literatura, pouco se sabe sobre os mecanismos pelos quais as ilhas de patogenicidade são transferidas (Hacker et al., 2004). O parentesco entre IPs, fagos e plasmídeos sugere que genes com propriedade de virulência ou patogenicidade que caracterizam uma IP sejam justamente carregados pelos EGMs, ou seja, esses elementos podem conter a ilha de patogenicidade (Dobrindt et al., 2000). Apesar de não possuírem IPs segundo a definição clássica, as regiões de profagos de Xf, listadas na tabela 5.5, apresentam fatores tipicamente presentes em ilhas de patogenicidade (toxinas e antitoxinas, fatores de virulência), considerados como principais determinantes da virulência em muitas bactérias patogênicas, como por exemplo Vibrio cholerae, Shigella flexernii, Helicobacter pylori e linhagens entero-patogênicas de Escherichia coli (EPEC) (Bjorkholm et al., 2001; Dobrindt et al., 2002; Dziejman et al., 2002; Tauschek et al., 2002).

Este trabalho mostra que foram identificados genes relacionados à virulência, contidos em regiões de profagos, que poderiam atuar como agentes responsáveis pela especificidade de hospedeiro ou até mesmo pela virulência (Tópico 4.7). Uma vez que esses genes não são necessários para sobrevivência ou manutenção de uma espécie, eles podem ser deletados do genoma sem nenhum grande prejuízo ao organismo; no entanto, essa deleção é sempre acompanhada por uma redução na virulência em paralelo (Medini et al., 2005). 
Tabela 5.5. Regiões de profagos com presença de ORFs relacionadas à virulência e/ou patogenicidade.

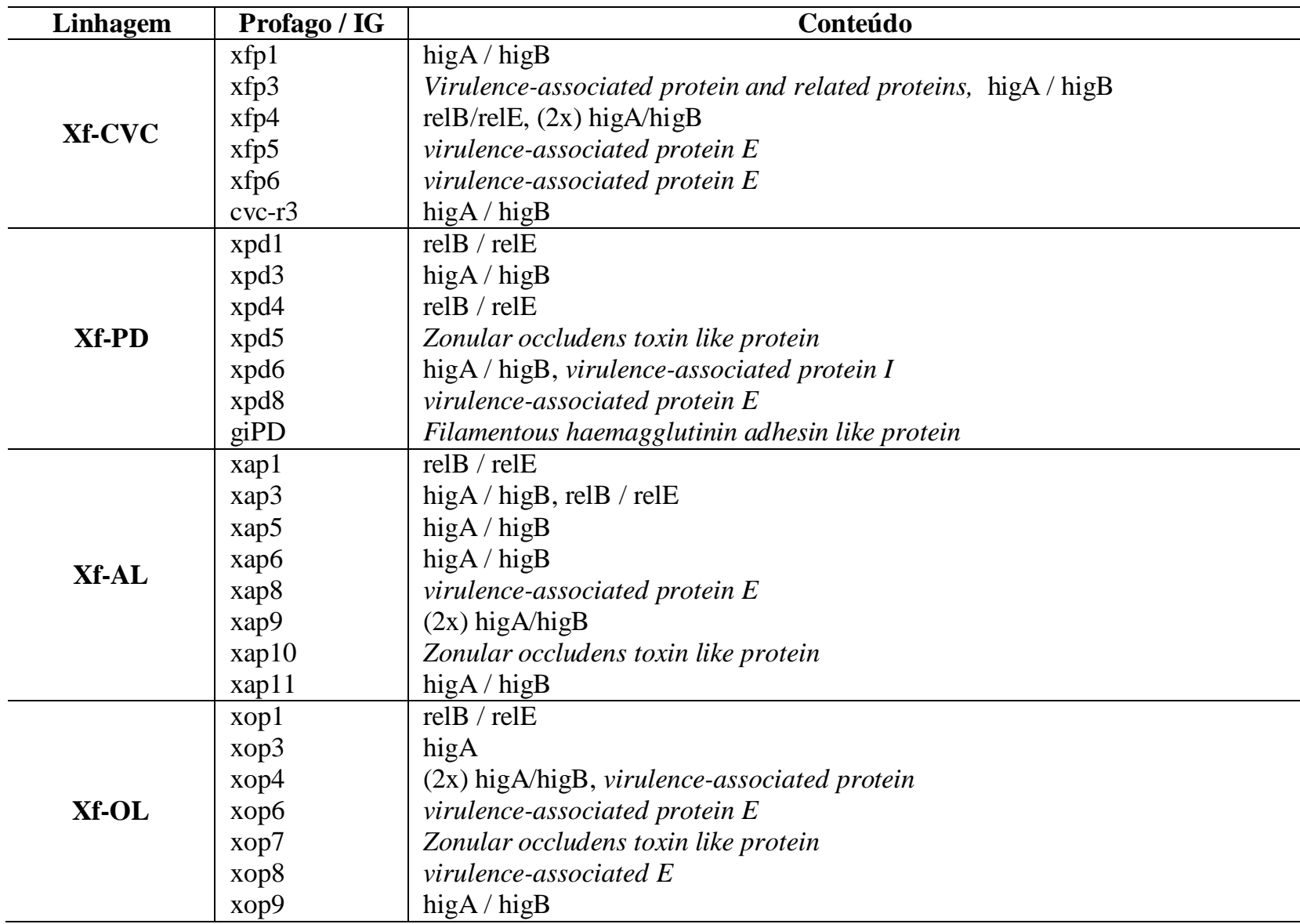

\subsection{DIVERSIDADE DAS REGIÕES RELACIONADAS A PROFAGOS: ORIGEM E EVOLUÇÃO}

Devido às regiões de profagos formarem uma proporção considerável do genoma de Xf e serem responsáveis pelas principais diferenças genômicas entre as linhagens, torna-se essencial a discussão a respeito da origem e evolução dessas regiões. Perguntas como: (i) Considerando as regiões de profagos identificadas, é possível inferir uma provável origem das mesmas? e (ii) Quais são os mecanismos genéticos que atuam na evolução genômica destas regiões?, tornam-se importantes e são discutidas a seguir.

A análise das ORFs estruturais de fagos por metodologia de BBH (Figura 4.27) indica que as regiões de profagos de Xf contêm ORFs estruturais predominantemente relacionadas às família Siphoviridae, e em menor grau também às famílias Myoviridae e Podoviridae (Tópico 4.7). Por outro lado, as integrases das regiões de profagos de Xf estão sempre associadas a integrases de fagos que apresentam invariavelmente mosaicismo genético (Tópico 4.3); análises 
comparativas sugerem que essas regiões em Xf também apresentem constituição de mosaicos genéticos, onde diversas regiões de profagos apresentam organização genômica híbrida proveniente de fagos de diferentes famílias, em particular na porção de ORFs estruturais (Tópi co $4.8)$.

Segundo Pedulla e colaboradores (2003), há pelo menos dois modelos que podem explicar o mecanismo relacionado com a geração de características estruturais de mosaicos nos genomas de fagos (em particular nos fagos que infectam o gênero Mycobacterium): (i) porções do genoma do fago seriam reorganizadas por recombinação homóloga a partir de pequenas sequiências de DNA conservadas e repetidas ao longo do genoma do fago, assim como é observado nos fagos HK620 e P27 (Clark et al., 2001); e (ii) intercâmbio de porções do genoma do profago e da bactéria por recombinação ilegítima e também pelo mecanismo de transdução generalizada.

Com base nos resultados apresentados pelas análises comparativas (Tópicos 4.7 e 4.8), sugere-se que ambos os modelos possam ter originado as regiões de profagos identificadas nas linhagens de Xf estudadas; apesar de ser impossível determinar com exatidão quando estes eventos ocorreram na história evolutiva, é possível criar uma hipótese sobre como estes eventos de recombinação e diversificação possam ter ocorrido. Ohnishi e colaboradores (2001) apresentam um modelo onde diferentes fagos que infectam a bactéria E. coli podem sofrer um intensivo mecanismo de recombinação e diversificação de seqüências durante e/ou depois do processo de infecção em um ambiente confinado (Figura 5.5).

Baseado no modelo de Ohnishi, este trabalho propõe uma hipótese que tenta explicar como os eventos de recombinação diversificaram os fagos que infectaram Xf. Esta hipótese sugere um modelo de múltiplas re-infecções, sendo baseada em cinco premissas: (i) Recombinação freqüente entre fagos similares dentro da própria célula de Xf, durante o processo de infecção; (ii) Incremento do repertório de fagos através da re-infecção em Xf com posterior repetição de (i); (iii) Em um ambiente confinado, como por exemplo, o xilema vegetal ou o sistema digestório do inseto vetor, estes fagos recombinantes podem infectar outras linhagens ou espécies, gerando novos fagos recombinantes, que eventualmente podem re-infectar Xf; (iv) Um fago de família diferente e distante, também susceptível a infectar Xf, pode recombinar com outros fagos ou profagos residentes no genoma, gerando outros tipos de fagos recombinantes (esta premissa já foi observada no fago P2 por Haggard-Ljungquist et al.,1992); e (v) Recombinação entre fagos e ilhas genômicas. Sendo importante destacar que em decorrência de (iii), (iv) e (v), novas ORFs não relacionadas a função de fagos podem ser introduzidas neste novo fago recombinante. 


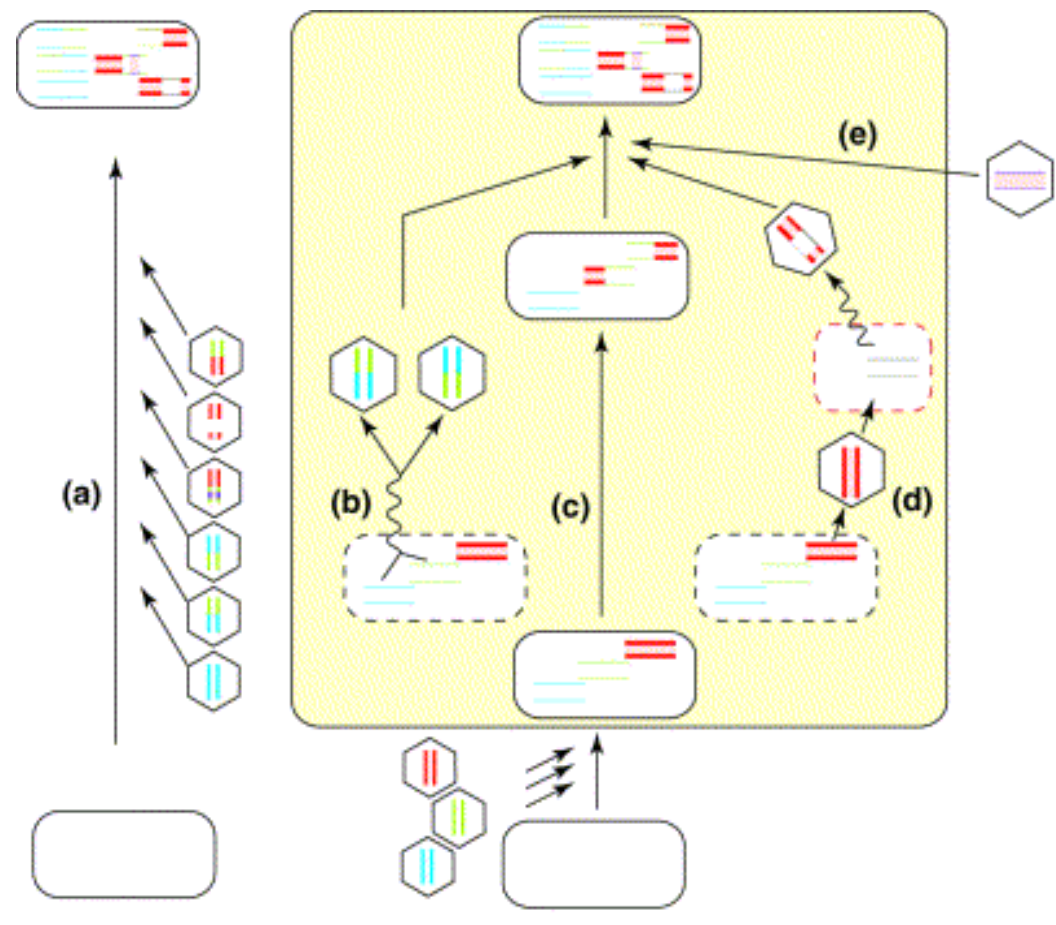

Figura 5.5. Mecanismo de recombinação e diversificação de fagos durante e/ou depois o processo de infecção em um ambiente confinado (modelo proposto por Ohnishi et al., 2001, para E. coli no intestino). (a) Independentes infecções seqüenciais; (b) Re-infecção de fagos recombinantes; (c) Geração de fagos mosaicos por recombinação; (d) Infecção de fagos recombinantes originados de outras espécies ou linhagens e (e) Recombinação entre um fago diferente proveniente de outro meio. Não estão ilustradas os eventos de transdução generalizada e especializada.Retângulos representam a célula bacteriana. .

A favor desta hipótese de múltiplas re-infecções em Xf há pelo menos duas evidências. As ORFs que codificam as fibras da cauda presentes nas regiões de profagos de Xf apresentam conservação de seqüência (estão no mesmo grupo de BBHs), sendo que estas estruturas da partícula do fago são essenciais para o processo de infecção e re-infecção de determinado fago para uma mesma bactéria. A segunda evidência está relacionada à presença de ORFs que aparentemente não apresentam função relacionada a fagos, no interior das regiões de profagos de Xf, indicando que novas ORFs foram e podem ser introduzidas através deste processo caracterizando eventos de transdução.

Seguindo esta linha de raciocínio, através destes eventos de recombinação, o repertório de fagos é diversificado, tornando a bactéria uma verdadeira "fábrica de fagos" capaz de liberar uma enorme variedade de fagos recombinantes no meio ambiente. 


\subsection{CONSIDERAÇÕES FINAIS}

Considerando-se os dados apresentados e discutidos até o momento, as tabelas 5.6 e 5.7 apresentam uma compilação sobre a diversidade das integrases de fagos e de seus profagos associados e das integrases de IGs.

Tabela 5.6. Compilação dos resultados referente às integrases de fagos.

\begin{tabular}{|c|c|c|c|c|c|c|c|}
\hline & $\begin{array}{c}\text { Tamanho } \\
\text { médio dos } \\
\text { EGMs } \\
\text { associados }\end{array}$ & $\begin{array}{c}\text { Proporção de } \\
\text { integrases } \\
\text { Completas e } \\
\text { FS/SCF }\end{array}$ & $\begin{array}{c}\text { Integrases em } \\
\text { genoma de } \\
\text { Fagos próximos }\end{array}$ & $\begin{array}{c}\text { Integrases em } \\
\text { genomas de } \\
\text { bactérias } \\
\text { próximas }\end{array}$ & $\begin{array}{c}\text { tRNAs como sítios } \\
\text { de inserção } 1 / \text { tRNA } \\
\text { Prevalente }\end{array}$ & $\begin{array}{c}\text { Apresenta ORFs } \\
\text { virulência / } \\
\text { patogenicidade ? }{ }^{2}\end{array}$ & $\begin{array}{l}\text { Provável } \\
\text { fago } \\
\text { completo? }\end{array}$ \\
\hline Ramo A & $31 \mathrm{~kb}$ & $16: 1$ & $\begin{array}{l}\text { psiM2/100, } \\
\text { phiE125 e } \\
\text { phi } 1025 \mathrm{~b}\end{array}$ & Pseudomonas sp & $\begin{array}{l}\operatorname{Sim}(41 \%) / \\
\text { tRNA-CYS }\end{array}$ & $\operatorname{Sim}(68 \%)$ & $\operatorname{Sim}(4)$ \\
\hline Ramo B & $26 \mathrm{~kb}$ & $4: 2$ & psiM2 /100 & Pseudomonas sp & $\begin{array}{l}\operatorname{Sim}(14 \%) / \\
\text { tRNA-GLY }\end{array}$ & $\operatorname{Sim}(50 \%)$ & $\operatorname{Sim}(1)$ \\
\hline Ramo C & $19 \mathrm{~kb}$ & 5 & (A) & (B) & $\begin{array}{l}\operatorname{Sim}(60 \%) / \\
\text { tRNA-SER }\end{array}$ & $\operatorname{Sim}(60 \%)$ & Não \\
\hline Ramo D & $42 \mathrm{~kb}$ & $5: 2$ & $\begin{array}{c}\text { Mycobacterium } \\
\text { phages }\end{array}$ & (C) & $\begin{array}{l}\text { Sim }(100 \%) / \\
\text { tRNA-VAL * }\end{array}$ & $\operatorname{Sim}(71 \%)$ & $\operatorname{Sim}(4)$ \\
\hline Ramo E & $36 \mathrm{~kb}$ & $4: 3$ & $\begin{array}{l}\text { hk022, hk97 e } \\
\text { lambda }\end{array}$ & $\begin{array}{c}\text { Xanthomonas sp } \\
/ \\
\text { Pseudomonas sp }\end{array}$ & $\begin{array}{l}\operatorname{Sim}(71 \%) / \\
\text { tRNA-ASN }\end{array}$ & $\operatorname{Sim}(100 \%)$ & Não \\
\hline
\end{tabular}

( ${ }^{1}$ Porcentagem referente ao número de integrases que são flanqueadas por tRNAs.

$\left(^{2}\right)$ Porcentagem referente ao número de regiões de profagos que contém ORFs relacionadas a virulência e/ou patogenicidade.

(A) Burkholderia phi52237, phiE202 e Bcepc6b; Mycobacterium omega

(B) Dechloromonas aromática; Myxococcus xanthus; Hahella chejuensis; Azoarcus sp

(C) Chlamydia trachomatis; Mycobacterium leprae; Pyrococcus abyssi; Pseudomonas mendocina

* Todas as integrases do ramo D estão flanqueadas por tRNA-VAL (exceto integrase giCVC).

Tabela 5.7. Compilação dos resultados referente às integrases de IGs.

\begin{tabular}{c|c|c|c|c|c}
\hline & $\begin{array}{c}\text { Tamanho dos EGMs } \\
\text { associados }\end{array}$ & $\begin{array}{c}\text { Integrases em genoma de } \\
\text { Fagos próximos }\end{array}$ & $\begin{array}{c}\text { Integrases em genomas de bactérias } \\
\text { próximas }\end{array}$ & $\begin{array}{c}\text { tRNAs como sítios } \\
\text { de inserção }\end{array}$ & $\begin{array}{c}\text { Provável } \\
\text { IP? }\end{array}$ \\
\hline giCVC & $67 \mathrm{~kb}$ & Pseudomonas F116 & $\begin{array}{c}\text { Xanthomonas vesicatoria / P. putida / } \\
\text { Burkholderia xenovorans }\end{array}$ & tRNA-GLY & Sim \\
\hline giPD & $16 \mathrm{~kb}$ & $\begin{array}{c}\text { Enterobacteria epsilon15 / } \\
\text { phiV10 }\end{array}$ & $\begin{array}{c}\text { Methylibium petroleiphilum / } \\
\text { Azotobacter vinelandii }\end{array}$ & - & Sim \\
\hline
\end{tabular}

Dentre as correlações que podem ser levantados a partir dessas tabelas, algumas merecem ser citadas:

(i) O Ramo A é o que apresenta maior número de integrases, composto praticamente por integrases completas, sendo que também apresentam as regiões de profagos candidatas a serem profagos completos em ao menos quatro casos; 
(ii) $\mathrm{O}$ Ramo $\mathbf{C}$ apresenta integrases com assinatura catalítica para tirosinas recombinases diferente das demais integrases. Também estão relacionadas com EGMs que estão em processo de inativação e/ou decaimento, pois estão contidas dentro das menores regiões de profagos, $50 \%$ são integrases que possuem FS/SCF e apenas uma integrase está em região de profago candidata a fago completo;

(iii) As integrases do ramo $\mathbf{E}$ estão contidas em regiões de profagos que contém ORFs relacionadas a atributos de virulência. Não apresentam nenhum indício de serem regiões capazes de sofrer indução e se tornarem ativas, ou seja, são regiões que podem apresentam estabilidade no genoma, podendo ser responsáveis por codificar fatores responsáveis pela especificidade a determinados hospedeiros;

(iv) As integrases estão associadas filogeneticamente com integrases de proteobactérias;

(v) As integrases contidas no ramo D utilizam unicamente o tRNA-VAL como sítio preferencial de inserção.

Este trabalho pretendeu abordar de forma quantitativa e qualitativa os eventos de TGL que ocorrem em Xf, mediados por integrases associadas a elementos genéticos móveis (como profagos e ilhas genômicas), enfocando na diversidade das integrases e na constituição gênica das regiões de profagos e IGs. Desta forma, contribuiu para o progresso do entendimento do modo de como os genomas das linhagens de Xf evoluem e diferenciam, sendo que os resultados deste estudo sugerem que atividade de fagos e IGs é de extrema importância para os processos evolutivos na espécie Xylella fastidiosa. 


\section{PERSPECTIVAS}

No decorrer desse estudo, ferramentas computacionais foram implementadas (phagenavigator e phage-navigator-comparative). Os protocolos desenvolvidos e utilizados neste trabalho para montagem das regiões de profagos (phage-navigator) abrem uma perspectiva para futuros projetos de seqüenciamento, pois se apresentam como uma alternativa eficaz para montagem de regiões desta natureza. Assim como a ferramenta de comparação por BBHs de proteomas de fagos (phage-navigator-comparative) apresenta perspectiva científica, enfocando a anotação de proteínas de fagos ou na definição de clusters de BBHs, resultando em abundante material para estudo acerca da biologia de fagos.

A despeito das regiões candidatas a prováveis ilhas de patogenicidade, futuros estudos direcionados para análise funcional das ORFs que codificam produtos relacionados à virulência apresentariam valiosa informação qualitativa acerca de quanto estas ORFs influenciam na relação patógeno-hospedeiro vegetal e o quanto elas estão relacionadas com a virulência bacteriana.

Em relação às integrases, os resultados obtidos nesse trabalho representam progressos no entendimento da atividade potencial destes elementos e seu impacto na organização dos genomas bacterianos. Recentemente, através da técnica de DNA shuffling, tentou-se gerar uma integrase que reconhecesse e se integrasse com mais facilidade a determinados sítios pré estipulados (Groth e Calos, 2004). A integração eficiente em uma seqüência nativa específica seria um avanço grande nas técnicas de engenharia genética. Assim, do ponto de vista biotecnológico, a criação de integrases customizadas por esta técnica teria amplas aplicações, incluindo desde estudos de genômica funcional até uso em terapia gênica, ou de uma forma muito interessante, como foi recentemente proposto por Jones e colaboradores (2007), na utilização de bacteriófagos como ferramentas moleculares para o controle de doenças em plantas. 


\section{CONCLUSÃO}

A elucidação dos fatores e mecanismos envolvidos na instabilidade dos genomas bacterianos e conseqüentemente na geração de novas variantes e linhagens é um dos objetivos científicos ainda longe de ser completamente entendido (Hochhut et al., 2006). A compreensão dos mecanismos de trocas horizontais de ilhas genômicas e fagos é essencial para um panorama mais claro de como a plasticidade genômica é mantida e como isso contribui para a evolução dos genomas, e em especial em Xf, tema deste trabalho.

Um primeiro passo para entender estes mecanismos está relacionado ao entendimento das integrases. Este trabalho identificou 56 integrases, sempre associadas com EGMs (profagos ou IGs), apresentando variação de formas (completas, FS/SCF e fragmentos) e assinatura catalítica pertencente à família das tirosinas recombinases. Sítios de integração relacionados a tRNAs foram determinados para $71 \%$ das regiões relacionadas a profagos, sendo o alvo oito tipos de tRNAs (VAL, GLY, LYS, CYS, ASN, SER, THR e ARG) . Verificou-se que os bacteriófagos integrados carregam genes não essenciais contendo potenciais atributos de virulência e/ou patogenicidade, que podem ser mantidos e transcritos em Xylella.

Este trabalho contribuiu para a compreensão de como fagos e ilhas genômicas desempenham um papel fundamental na evolução do genoma de Xf, tanto a curto prazo, provocando alterações abruptas associadas a rearranjos no genoma, ou por deleções internas dentro das regiões de profagos sugerindo decaimento genômico; como a longo prazo, podendo ser responsáveis pela diferenciação entre linhagens, tornando uma linhagem em particular mais adaptada a determinado hospedeiro ou mais virulenta e/ou patogênica, em relação a outras linhagens, pela aquisição de conjuntos de genes responsáveis por atributos de virulência. E, por fim, sendo estes eventos intrinsecamente dependentes da atividade das integrases, conclui-se que, apesar do mecanismo de diferenciação entre linhagens ainda ser pouco compreendido, as evidências apresentadas confirmam que, em Xf, as integrases associadas com seus elementos genéticos desempenham papel fundamental na evolução e diferenciação de linhagens. 


\section{REFERÊNCIAS BIBLIOGRÁFICAS ${ }^{3}$}

Ackermann HW, DuBow MS. Viruses of Prokaryotes, General Properties of Bacteriophages. Boca Raton; CRC Press; v. $1,1987$.

Alberts B, Johnson A, Lewis J. Molecular Biology of the Cell. 4. ed. New York: Garland Publishing; 2002.

Allison GE, Angeles D, Tran-Dinh N, Verma NK. Complete genomic sequence of SfV, a serotype-converting temperate bacteriophage of Shigella flexneri. J Bacteriol. 2002; 184(7):1974-87.

Almeida LG, Paixao R, Souza RC, Costa GC, Almeida DF, Vasconcelos AT. A new set of bioinformatics tools for genome projects. Genet Mol Res. 2004b; 3(1):26-52.

Almeida LG, Paixao R, Souza RC, Costa GC, Barrientos FJ, Santos MT, Almeida DF, Vasconcelos AT. A System for Automated Bacterial (genome) Integrated Annotation--SABIA. Bioinformatics. 2004a; 20(16):2832-3.

Altschul SF, Madden TL, Schaffer AA, Zhang J, Zhang Z, Miller W, Lipman DJ. Gapped BLAST and PSI-BLAST: a new generation of protein database search programs. Nucleic Acids Res. 1997; 25:3389-3402.

Angly FE, Felts B, Breitbart M, Salamon P, Edwards RA, Carlson C, Chan AM, Haynes M, Kelley S, Liu H, Mahaffy JM, Mueller JE, Nulton J, Olson R, Parsons R, Rayhawk S, Suttle CA, Rohwer F. The marine viromes of four oceanic regions. PLoS Biol. 2006; 4:e368.

Avery OT, MacLeod CM, McCarty M. Studies on the chemical nature of the substance inducing transformation of pneumococcal types. Induction of transformation by a desoxyribonucleic acid fraction isolated from Pneumococcus type III. 1944. Mol Med. 1995;1:344-65.

Bairoch A, Boeckmann B. The SWISS-PROT protein sequence data bank: current status. Nucleic Acids Res. 1994; 22(17):3578-80.

Beres SB, Sylva GL, Barbian KD, Lei B, Hoff JS, Mammarella ND, Liu MY, Smoot JC, Porcella SF, Parkins LD, Campbell DS, Smith TM, McCormick JK, Leung DY, Schlievert PM, Musser JM. Genome sequence of a serotype M3 strain of group A Streptococcus: phage-encoded toxins, the high-virulence phenotype, and clone emergence. Proc Natl Acad Sci U S A. 2002; 99(15):10078-83.

Berisha B, Chen YD, Zhang GY, Xu BY, Chen TA. Isolation of Peirce's disease bacteria from grapevines in Europe. Eur. J. Plant Pathol. 1998; 104(5): 427-433.

Bhattacharyya A, Stilwagen S, Ivanova N, D'Souza M, Bernal A, Lykidis A, Kapatral V, Anderson I, Larsen N, Los T, Reznik G, Selkov E Jr, Walunas TL, Feil H, Feil WS, Purcell A, Lassez JL, Hawkins TL, Haselkorn R, Overbeek R, Predki PF, Kyrpides NC. Whole-genome comparative analysis of three phytopathogenic Xylella fastidiosa strains. Proc Natl Acad Sci USA. 2002; 99(19):12403-8.

Binnewies TT, Motro Y, Hallin PF, Lund O, Dunn D, La T, Hampson DJ, Bellgard M, Wassenaar TM, Ussery DW. Ten years of bacterial genome sequencing: comparative-genomics-based discoveries. Funct Integr Genomics. 2006; 3:165-85.

Björkholm B, Sjölund M, Falk PG, Berg OG, Engstrand L, Andersson DI. Mutation frequency and biological cost of antibiotic resistance in Helicobacter pylori. Proc Natl Acad Sci U S A. 2001; 98(25):14607-12.

Bose M, Barber R. Prophage Finder: a prophage loci prediction tool for prokaryotic genome sequences. In Silico Biol. 2006; 6(3):223-7.

Brent MR. Genome annotation past, present, and future: How to define an ORF at each locus. Genome Res. 2005; 15:1777-1786.

Brussow H, Canchaya C, Hardt WD. Phages and the evolution of bacterial pathogens: from genomic rearrangements to lysogenic conversion. Microbiol Mol Biol Rev. 2004; 68(3):560-602.

${ }^{3}$ De acordo com: International Committee of Medical Journal Editors. Uniform requirement for manuscripts submitted to Biomedical Journal: sample references. Avaliable from: http://www.icmje.org [2004 May 06]. 
Buell CR, Joardar V, Lindeberg M, Selengut J, Paulsen IT, Gwinn ML, Dodson RJ, Deboy RT, Durkin AS, Kolonay JF, Madupu R, Daugherty S, Brinkac L, Beanan MJ, Haft DH, Nelson WC, Davidsen T, Zafar N, Zhou L, Liu J, Yuan Q, Khouri H, Fedorova N, Tran B, Russell D, Berry K, Utterback T, Van Aken SE, Feldblyum TV, D'Ascenzo M, Deng WL, Ramos AR, Alfano JR, Cartinhour S, Chatterjee AK, Delaney TP, Lazarowitz SG, Martin GB, Schneider DJ, Tang X, Bender CL, White O, Fraser CM, Collmer A. The complete genome sequence of the Arabidopsis and tomato pathogen Pseudomonas syringae pv. tomato DC3000. Proc Natl Acad Sci U S A. 2003 Sep 2;100(18):10181-6.

Byrne M, Kropinski AM. The genome of the Pseudomonas aeruginosa generalized transducing bacteriophage F116. Gene. $2005 ; 346: 187-94$

Campbell AM. Chromosomal insertion sites for phages and plasmids. J Bacteriol. 1992; 174(23):7495-9.

Campbell AM. Lateral gene transfer in prokaryotes. Theor Popul Biol. 2000; 57(2):71-7.

Campoy S, Aranda J, Alvarez G, Barbé J, Llagostera M. Isolation and sequencing of a temperate transducing phage for Pasteurella multocida. Appl Environ Microbiol. 2006; 72(5):3154-60.

Canchaya C, Fournous G, Chibani-Chennoufi S, Dillmann ML, Brussow H. Phage as agents of lateral gene transfer. Curr Opin Microbiol. 2003b; 6(4):417-24.

Canchaya C, Proux C, Fournous G, Bruttin A, Brussow H. Prophage genomics. Microbiol Mol Bio Rev. 2003a; 67:238276.

Casjens S, Winn-Stapley DA, Gilcrease EB, Morona R, Kühlewein C, Chua JE, Manning PA, Inwood W, Clark AJ. The chromosome of Shigella flexneri bacteriophage Sf6: complete nucleotide sequence, genetic mosaicism, and DNA packaging. J Mol Biol. 2004; 339(2):379-94.

Casjens S. Prophages and bacterial genomics: what have we learn so far? Mol Microbiol. 2003; 49:277-300.

Casjens SR, Gilcrease EB, Winn-Stapley DA, Schicklmaier P, Schmieger H, Pedulla ML, Ford ME, Houtz JM, Hatfull GF, Hendrix RW. The generalized transducing Salmonella bacteriophage ES18: complete genome sequence and DNA packaging strategy. J Bacteriol. 2005; 187(3):1091-104.

Clark AJ, Inwood W, Cloutier T, Dhillon TS. Nucleotide sequence of coliphage HK620 and the evolution of lambdoid phages. J Mol Biol. 2001; 24;311(4):657-79.

Cole JR, Chai B, Marsh TL, Farris RJ, Wang Q, Kulam SA, Chandra S, McGarrell DM, Schmidt TM, Garrity GM, Tiedje JM; Ribosomal Database Project. The Ribosomal Database Project (RDP-II): previewing a new autoaligner that allows regular updates and the new prokaryotic taxonomy. Nucleic Acids Res. 2003; 31(1):442-3.

Cole ST, Eiglmeier K, Parkhill J, James KD, Thomson NR, Wheeler PR, Honoré N, Garnier T, Churcher C, Harris D, Mungall K, Basham D, Brown D, Chillingworth T, Connor R, Davies RM, Devlin K, Duthoy S, Feltwell T, Fraser A, Hamlin N, Holroyd S, Hornsby T, Jagels K, Lacroix C, Maclean J, Moule S, Murphy L, Oliver K, Quail MA, Rajandream MA, Rutherford KM, Rutter S, Seeger K, Simon S, Simmonds M, Skelton J, Squares R, Squares S, Stevens K, Taylor K, Whitehead S, Woodward JR, Barrell BG. Massive gene decay in the leprosy bacillus. Nature. 2001; 409(6823):1007-11.

Davies MR, McMillan DJ, Van Domselaar GH, Jones MK, Sriprakash KS. Phage 3396 from a Streptococcus dysgalactiae subsp. equisimilis pathovar may have its origins in streptococcus pyogenes. J Bacteriol. 2007; 189(7):2646-52.

Davis MJ, Gillaspie AG, Vidaver AK, Harris RW. Clavibacter, a new genus containing some phytopathogenic coryneform bacteria Clavibacter xyli subsp. xyli sp.nov., subsp. nov. and Clavibacter xyli subsp. cynodontis subsp. nov., pathogens that cause ratoon stunting disease of sugarcane and Bermudagrass stunting disease. Int J Syst Bacteriol. 1984; 34:107-117.

Davis MJ, Purcell AH, Thomson SV. Pierce's disease of grapevines: isolation of the causal bacterium. Science. 1978; 199: 75-77.

De La Fuente L, Burr TJ, Hoch HC. Mutations in type I and type IV pilus biosynthetic genes affect twitching motility rates in Xylella fastidiosa. J Bacteriol. 2007; 189:7507-10.

De Magistris MT. Zonula occludens toxin as a new promising adjuvant for mucosal vaccines. Vaccine. 2006; 24:S2-60-1.

Delcher AL, Phillippy A, Carlton J, Salzberg, SL. Fast algorithms for large-scale genome alignment and comparison. Nucleic Acids Res. 2002; 30:2478-2483.

Dhillon TS, Poon AP, Chan D, Clark AJ. General transducing phages like Salmonella phage P22 isolated using a smooth strain of Escherichia coli as host. FEMS Microbiol Lett. 1998; 1;161(1):129-33. 
Di Pierro M, Lu R, Uzzau S, Wang W, Margaretten K, Pazzani C, Maimone F, Fasano A. Zonula occludens toxin structure-function analysis. Identification of the fragment biologically active on tight junctions and of the zonulin receptor binding domain. J Biol Chem. 2001; 276(22):19160-5.

Dobrindt U, Hentschel U, Kaper JB, Hacker J. Genome plasticity in pathogenic and nonpathogenic enterobacteria. Curr Top Microbiol Immunol. 2002; 264(1):157-75.

Dobrindt U, Hochhut B, Hentschel U, Hacker J. Genomic islands in pathogenic and environmental microorganisms. Nat Rev Microbiol. 2004; 2(5):414-24.

Dobrindt U, Janke B, Piechaczek K, Nagy G, Ziebuhr W, Fischer G, Schierhorn A, Hecker M, Blum-Oehler G, Hacker J. Toxin genes on pathogenicity islands: impact for microbial evolution. Int J Med Microbiol. 2000; 290(4-5):307-11.

Droge M, Puhler A, Selbitschka W. Horizontal gene transfer as a biosafety issue: a natural phenomenon of public concern. J Biotechnol. 1998; 64(1):75-90.

Dziejman M, Balon E, Boyd D, Fraser CM, Heidelberg JF, Mekalanos JJ. Comparative genomic analysis of Vibrio cholerae: genes that correlate with cholera endemic and pandemic disease. Proc Natl Acad Sci U S A. 2002; 99(3):155661.

Edgar RC. MUSCLE: multiple sequence alignment with high accuracy and high throughput. Nucleic Acids Res. 2004; 32(5):1792-97.

Eisen JA. Horizontal gene transfer among microbial genomes: new insights from complete genome analysis. Curr Opin Genet Dev. 2000; 10(6):606-11.

Ewing B, Green P. Base-calling of automated sequencer traces using phred. II. Error probabilities. Genome Res. 1998; $8(3): 186-94$.

Falkow S. Infectious Multiple Drug Resistance. Londres: Pion, 1975. Fasano A, Uzzau S. Modulation of intestinal tight junctions by Zonula occludens toxin permits enteral administration of insulin and other macromolecules in an animal model. J Clin Invest. 1997; 99(6):1158-64.

Fasano A, Uzzau S. Modulation of intestinal tight junctions by Zonula occludens toxin permits enteral administration of insulin and other macromolecules in an animal model. J Clin Invest. 1997; 99:1158-64.

Feil H, Feil WS, Chain P, Larimer F, DiBartolo G, Copeland A, Lykidis A, Trong S, Nolan M, Goltsman E, Thiel J, Malfatti S, Loper JE, Lapidus A, Detter JC, Land M, Richardson PM, Kyrpides NC, Ivanova N, Lindow SE. Comparison of the complete genome sequences of Pseudomonas syringae pv. syringae B728a and pv. tomato DC3000. Proc Natl Acad Sci U S A. 2005 102(31):11064-9

Felsenstein J. PHYLIP (Phylogeny Inference Package) version 3.6. Distributed by the author. Department of Genome Sciences, University of Washington, Seattle; 2005.

Fiers W, Contreras R, Duerinck F, Haegeman G, Iserentant D, Merregaert J, Min Jou W, Molemans F, Raeymaekers A, Van den Berghe A, Volckaert G, Ysebaert M. Complete nucleotide sequence of bacteriophage MS2 RNA: primary and secondary structure of the replicase gene. Nature. 1976; 260(5551):500-7.

Ford ME, Sarkis GJ, Belanger AE, Hendrix RW, Hatfull GF. Genome structure of mycobacteriophage D29: implications for phage evolution. J Mol Biol. 1998; 279(1):143-64.

Fouts DE. Phage_Finder: automated identification and classification of prophage regions in complete bacterial genome sequences. Nucleic Acids Res. 2006; 34(20):5839-51.

Frost LS, Leplae R, Summers AO, Toussaint A. Mobile genetic elements: the agents of open source evolution. Nat Rev Microbiol. 2005 Sep;3(9):722-32.

Fry SM, Milholland RD. Multiplication and translocation of Xylella fastidiosa in petioles and stems of grapevine resistant, tolerant, and susceptible to Pierce's disease. Phytopathology. 1990; 80(1):61-65.

Furuya EY, Lowy FD. Antimicrobial-resistant bacteria in the community setting. Nat Rev Microbiol. 2006; 4(1):36-45.

Gal-Mor O, Finlay BB. Pathogenicity islands: a molecular toolbox for bacterial virulence. Cell Microbiol. 2006; 8(11):1707-19. 
George RA, Spriggs RV, Thornton JM, Al-Lazikani B, Swindells MB. SCOPEC: a database of protein catalytic domains. Bioinformatics. 2004; 20 Suppl 1:i130-6.

Gogarten JP, Doolittle WF, Lawrence JG. Prokaryotic evolution in light of gene transfer. Mol Biol Evol. 2002; $19(12): 2226-38$.

Gordon D, Abajian C, Green P. Consed: a graphical tool for sequence finishing. Genome Res. 1998; 8(3):195-202.

Griffith F. The significance of pneumococcal types. J Hyg. 1928; 64(2):129-175.

Grigoriev A. Analyzing genomes with cumulative skew diagrams. Nucleic Acids Res. 1998 May 15;26(10):2286-90.

Grindley ND, Whiteson KL, Rice PA. Mechanisms of site-specific recombination. Annu Rev Biochem. 2006; 75:567-605.

Groisman EA, Ochman H. Pathogenicity islands: bacterial evolution in quantum leaps. Cell. 1996; 87(5):791-4.

Groth AC, Calos MP. Phage integrases: biology and applications. J Mol Biol. 2004; 335(3):667-78.

Hacker J, Carniel E. Ecological fitness, genomic islands and bacterial pathogenicity: a Darwinian view of the evolution of microbes. EMBO Rep. 2001; 2(5):376-81.

Hacker J, Hochhut B, Middendorf B, Schneider G, Buchrieser C, Gottschalk G, Dobrindt U. Pathogenomics of mobile genetic elements of toxigenic bacteria. Int J Med Microbiol. 2004; 293(7-8):453-61.

Hacker J, Kaper JB. Pathogenicity islands and the evolution of microbes. Annu Rev Microbiol. 2000; 54:641-79.

Haggard-Ljungquist E, Halling C, Calendar R. DNA sequences of the tail fiber genes of bacteriophage P2: evidence for horizontal transfer of tail fiber genes among unrelated bacteriophages. J Bacteriol. 1992; 174(5):1462-77.

Hall TA. BioEdit: a user-friendly biological sequence alignment editor and analysis program for Windows 95/98/NT. Nucl Acids Symp Ser. 1999; 41:95-98.

Hartung JS, Beretta J, Brlansky RH, Spisso S, Lee RF. Citrus variegated chlorosis bacterium: axenic culture, pathogenicity, and serological relationships with other strains of Xylella fastidiosa. Phytopathology. 1994; 84(6):591-597.

Hentschel U, Steinert M, Hacker J. Common molecular mechanisms of symbiosis and pathogenesis. Trends Microbiol. 2000; 8(5):226-31.

Highlander SK, Weissenberger S, Alvarez LE, Weinstock GM, Berget PB. Complete nucleotide sequence of a P2 family lysogenic bacteriophage, varphiMhaA1-PHL101, from Mannheimia haemolytica serotype A1. Virology. 2006; 350(1):7989.

Hochhut B, Wilde C, Balling G, Middendorf B, Dobrindt U, Brzuszkiewicz E, Gottschalk G, Carniel E, Hacker J. Role of pathogenicity island-associated integrases in the genome plasticity of uropathogenic Escherichia coli strain 536. Mol Microbiol. 2006; 61(3):584-95.

Holden BJ, Pinney JW, Lovell SC, Amoutzias GD, Robertson DL. An exploration of alternative visualisations of the basic helix-loop-helix protein interaction network. BMC Bioinformatics. 2007; 8:289.

Hopkins DL, Thompson CM, Wichman RL, Bistline FW, Russo LW. Effect of inoculation of mature citrus trees in the grove with Xylella fastidiosa on citrus blight incidence. Proc Fla State Hort Soc. 1995; 108:103-106.

Hopkins DL. Xylella fastidiosa: xylem-limited bacterial pathogen of plants. Annu Rev Phytopathol. 1989; 27:271-290.

Hsiao W, Wan I, Jones SJ, Brinkman FS. IslandPath: aiding detection of genomic islands in prokaryotes. Bioinformatics. 2003; 19(3):418-20.

Huang X, Madan A. CAP3: A DNA sequence assembly program. Genome Res. 1999; 9(9):868-77

Jiang W, Chang J, Jakana J, Weigele P, King J, Chiu W. Structure of epsilon15 bacteriophage reveals genome organization and DNA packaging/injection apparatus. Nature. 2006; 439(7076):612-6.

Jones JB, Jackson LE, Balogh B, Obradovic A, Iriarte FB, Momol MT. Bacteriophages for plant disease control. Annu Rev Phytopathol. 2007; 45:245-62.

Juhala RJ, Ford ME, Duda RL, Youlton A, Hatfull GF, Hendrix RW. Genomic sequences of bacteriophages HK97 and HK022: pervasive genetic mosaicism in the lambdoid bacteriophages. J Mol Biol. 2000; 299(1):27-51. 
Koonin EV, Makarova KS, Aravind L. Horizontal gene transfer in prokaryotes: quantification and classification. Annu Rev Microbiol. 2001; 55:709-42.

Kouranov A, Xie L, de la Cruz J, Chen L, Westbrook J, Bourne PE, Berman HM. The RCSB PDB information portal for structural genomics. Nucleic Acids Res. 2006; 34:D302-5.

Kropinski AM. Sequence of the genome of the temperate, serotype-converting, Pseudomonas aeruginosa bacteriophage D3. J Bacteriol. 2000; 182(21):6066-74.

Kumar S, Tamura K, Nei M. MEGA3: integrated software for molecular evolutionary genetics analysis and sequence alignment. Brief Bioinform. 2004; 5:150-163.

Kwon HJ, Tirumalai R, Landy A, Ellenberger T. Flexibility in DNA recombination: structure of the lambda integrase catalytic core. Science. 1997; 276 126-131.

Lammers WT. Stimulation of bacterial cytokinesis by bacteriophage predation. Hydrobiologia. 1992; 235/236:261-265.

Lawrence JG, Roth JR. Selfish operons: horizontal transfer may drive the evolution of gene clusters. Genetics. 1996; 143(4):1843-60.

Lee MH, Hatfull GF. Mycobacteriophage L5 integrase-mediated site-specific integration in vitro. J Bacteriol. 1993; 175(21):6836-41.

Leite B, Andersen PC, Ishida ML. Colony aggregation and biofilm formation in xylem chemistry-based media for Xylella fastidiosa. FEMS Microbiol Lett. 2004; 230(2):283-90.

Leu LS, Su CC. Isolation, cultivation, and pathogenicity of Xylella fastidiosa, the causal bacterium of pear leaf scorch disease in Taiwan. Plant Disease. 1993; 77(6): 642-646.

Lima WC, Van Sluys MA, Menck CF. Non-gamma-proteobacteria gene islands contribute to the Xanthomonas genome. OMICS. 2005; 9(2):160-72.

Liu M, Gingery M, Doulatov SR, Liu Y, Hodes A, Baker S, Davis P, Simmonds M, Churcher C, Mungall K, Quail MA, Preston A, Harvill ET, Maskell DJ, Eiserling FA, Parkhill J, Miller JF. Genomic and genetic analysis of Bordetella bacteriophages encoding reverse transcriptase-mediated tropism-switching cassettes. J Bacteriol. 2004; 186(5):1503-17.

Liu T, Haggard-Ljungquist E. The transcriptional switch of bacteriophage WPhi, a P2-related but heteroimmune coliphage. J Virol. 1999; 73(12):9816-26.

Lowe TM, Eddy SR. tRNAscan-SE: a program for improved detection of transfer RNA genes in genomic sequence. Nucleic Acids Res. 1997; 25:955-964.

Luo Y, Pfister P, Leisinger T, Wasserfallen A. The genome of archaeal prophage PsiM100 encodes the lytic enzyme responsible for autolysis of Methanothermobacter wolfeii. Bacteriology. 2001; 183:5788-92.

Lwoff A. Lysogeny. Bacteriol Rev. 1953; 17(4):269-337.

Magnuson RD. Hypothetical functions of toxin-antitoxin systems. J Bacteriol. 2007;1 89(17):6089-92.

Maniloff J, Kampo GJ, Dascher CC. Sequence analysis of a unique temperature phage: mycoplasma virus L2. Gene. 1994; 141(1):1-8.

Marchler-Bauer A, Anderson JB, Cherukuri PF, DeWeese-Scott C, Geer LY, Gwadz M, He S, Hurwitz DI, Jackson JD, Ke Z, Lanczycki CJ, Liebert CA, Liu C, Lu F, Marchler GH, Mullokandov M, Shoemaker BA, Simonyan V, Song JS, Thiessen PA, Yamashita RA, Yin JJ, Zhang D, Bryant SH. CDD: a Conserved Domain Database for protein classification. Nucleic Acids Res. 2005; 33:D192-6.

McClintock B. The origin and behavior of mutable loci in maize. Proc Natl Acad Sci U S A. 1950; 36(6):344-55.

Medini D, Donati C, Tettelin H, Masignani V, Rappuoli R. The microbial pan-genome. Curr Opin Genet Dev. 2005; 15(6):589-94.

Meidanis J, Braga MD, Verjovski-Almeida S. Whole-genome analysis of transporters in the plant pathogen Xylella fastidiosa. Microbiol Mol Biol Rev. 2002; 66(2):272-99.

Merril CR, Scholl D, Adhya SL. The prospect for bacteriophage therapy in Western medicine. Nat Rev Drug Discov. 2003; 2(6):489-97. 
Milkman R. Recombination and population structure in Escherichia coli. Genetics. 1997; 146(3):745-50.

Miller RV, Pemberton JM, Clark AJ. Prophage F116: evidence for extrachromosomal location in Pseudomonas aeruginosa strain PAO. J Virol. 1977; 22:844-847.

Miyamoto H, Nakai W, Yajima N, Fujibayashi A, Higuchi T, Sato K, Matsushiro A. Sequence analysis of Stx2-converting phage VT2-Sa shows a great divergence in early regulation and replication regions. DNA Res. 1999; 6:235-40.

Mmolawa PT, Schmieger H, Heuzenroeder MW. Bacteriophage ST64B, a genetic mosaic of genes from diverse sources isolated from Salmonella enterica serovar typhimurium DT 64. J Bacteriol. 2003; 185:6481-5.

Moebus K, Nattkemper H. Bacteriophage sensitivity patterns among bacteria isolated from marine waters. Helgoländer Meeresunters. 1981; 34:375-385.

Moebus K. Lytic and inhibition responses to bacteriophages among marine bacteria, with special reference to the origin of phage-host systems. Helgoländer Meeresunters. 1983; 36:375-391.

Mollenhauer HH, Hopkins DL. Xylem morphology of Pierce's disease infected grapevines with different levels of tolerance. Physiol Plant Pathol. 1976; 9: 95-100.

Monteiro-Vitorello CB, Camargo LE, Van Sluys MA, Kitajima JP, Truffi D, do Amaral AM, Harakava R, de Oliveira JC, Wood D, de Oliveira MC, Miyaki C, Takita MA, da Silva AC, Furlan LR, Carraro DM, Camarotte G, Almeida NF Jr, Carrer H, Coutinho LL, El-Dorry HA, Ferro MI, Gagliardi PR, Giglioti E, Goldman MH, Goldman GH, Kimura ET, Ferro ES, Kuramae EE, Lemos EG, Lemos MV, Mauro SM, Machado MA, Marino CL, Menck CF, Nunes LR, Oliveira RC, Pereira GG, Siqueira W, de Souza AA, Tsai SM, Zanca AS, Simpson AJ, Brumbley SM, Setúbal JC. The genome sequence of the gram-positive sugarcane pathogen Leifsonia xyli subsp. xyli. Mol Plant Microbe Interact. 2004; 17(8):827-36.

Monteiro-Vitorello CB, Oliveira MC, Zerillo MM, Varani AM, Civerolo E, Van Sluys MA. Xylella and Xanthomonas mobil'omics. OMICS 2005; 9(2):146-59.

Mulder NJ, Apweiler R, Attwood TK, Bairoch A, Bateman A, Binns D, Bork P, Buillard V, Cerutti L, Copley R, Courcelle E, Das U, Daugherty L, Dibley M, Finn R, Fleischmann W, Gough J, Haft D, Hulo N, Hunter S, Kahn D, Kanapin A, Kejariwal A, Labarga A, Langendijk-Genevaux PS, Lonsdale D, Lopez R, Letunic I, Madera M, Maslen J, McAnulla C, McDowall J, Mistry J, Mitchell A, Nikolskaya AN, Orchard S, Orengo C, Petryszak R, Selengut JD, Sigrist CJ, Thomas PD, Valentin F, Wilson D, Wu CH, Yeats C. New developments in the InterPro database. Nucleic Acids Res. 2007; 35:D224-8.

Nakayama K, Kanaya S, Ohnishi M, Terawaki Y, Hayashi T. The complete nucleotide sequence of phi CTX, a cytotoxinconverting phage of Pseudomonas aeruginosa: implications for phage evolution and horizontal gene transfer via bacteriophages. Mol Microbiol. 1999; 31(2):399-419.

Nelson KE, Weinel C, Paulsen IT, Dodson RJ, Hilbert H, Martins dos Santos VA, Fouts DE, Gill SR, Pop M, Holmes M, Brinkac L, Beanan M, DeBoy RT, Daugherty S, Kolonay J, Madupu R, Nelson W, White O, Peterson J, Khouri H, Hance I, Chris Lee P, Holtzapple E, Scanlan D, Tran K, Moazzez A, Utterback T, Rizzo M, Lee K, Kosack D, Moestl D, Wedler H, Lauber J, Stjepandic D, Hoheisel J, Straetz M, Heim S, Kiewitz C, Eisen JA, Timmis KN, Düsterhöft A, Tümmler B, Fraser CM. Complete genome sequence and comparative analysis of the metabolically versatile Pseudomonas putida KT2440.Environ Microbiol. 2002 Dec;4(12):799-808.

Nicholas KB, Nicholas Jr HB., Deerfield DW. GeneDoc: analysis and visualization of genetic variation. EMBNEW NEWS. 1997; 4:14.

Ochman H, Lawrence JG, Groisman EA. Lateral gene transfer and the nature of bacterial innovation. Nature. 2000; 405(6784):299-304.

Ochman H, Lerat E, Daubin V. Examining bacterial species under the specter of gene transfer and exchange. Proc Natl Acad Sci USA. 2005; 102 Suppl 1:6595-9.

Ohnishi M, Kurokawa K, Hayashi T. Diversification of Escherichia coli genomes: are bacteriophages the major contributors? Trends Microbiol. 2001 Oct;9(10):481-5.

Olson SA. EMBOSS opens up sequence analysis. European Molecular Biology Open Software Suite. Brief Bioinform. 2002; 3(1):87-91. 
Ottolenghi E, Macleod CM. Genetic transformation among living pneumococci in the mouse. Proc Natl Acad Sci U S A. $1963 ; 50: 417-9$.

Overbeek R, Fonstein M, D'Souza M, Pusch GD, Maltsev N. The use of gene clusters to infer functional coupling. Proc Natl Acad Sci USA. 1999; 96(6):2896-901.

Pallen MJ, Wren BW. Bacterial pathogenomics. Nature. 2007; 449(7164):835-42.

Parkhill J, Wren BW, Thomson NR, Titball RW, Holden MT, Prentice MB, Sebaihia M, James KD, Churcher C, Mungall KL, Baker S, Basham D, Bentley SD, Brooks K, Cerdeño-Tárraga AM, Chillingworth T, Cronin A, Davies RM, Davis P, Dougan G, Feltwell T, Hamlin N, Holroyd S, Jagels K, Karlyshev AV, Leather S, Moule S, Oyston PC, Quail M, Rutherford K, Simmonds M, Skelton J, Stevens K, Whitehead S, Barrell BG. Genome sequence of Yersinia pestis, the causative agent of plague. Nature. 2001 Oct 4;413(6855):523-7.

Paulsen IT, Press CM, Ravel J, Kobayashi DY, Myers GS, Mavrodi DV, DeBoy RT, Seshadri R, Ren Q, Madupu R, Dodson RJ, Durkin AS, Brinkac LM, Daugherty SC, Sullivan SA, Rosovitz MJ, Gwinn ML, Zhou L, Schneider DJ, Cartinhour SW, Nelson WC, Weidman J, Watkins K, Tran K, Khouri H, Pierson EA, Pierson LS 3rd, Thomashow LS, Loper JE. Complete genome sequence of the plant commensal Pseudomonas fluorescens Pf-5. Nat Biotechnol. 2005 Jul;23(7):873-8.

Pedulla ML, Ford ME, Houtz JM, Karthikeyan T, Wadsworth C, Lewis JA, Jacobs-Sera D, Falbo J, Gross J, Pannunzio NR, Brucker W, Kumar V, Kandasamy J, Keenan L, Bardarov S, Kriakov J, Lawrence JG, Jacobs WR Jr, Hendrix RW, Hatfull GF. Origins of highly mosaic mycobacteriophage genomes. Cell. 2003; 113(2):171-82.

Pena CE, Kahlenberg JM, Hatfull GF. Protein-DNA complexes in mycobacteriophage L5 integrative recombination. J Bacteriol. 1999; 181(2):454-61.

Perna NT, Plunkett G 3rd, Burland V, Mau B, Glasner JD, Rose DJ, Mayhew GF, Evans PS, Gregor J, Kirkpatrick HA, Pósfai G, Hackett J, Klink S, Boutin A, Shao Y, Miller L, Grotbeck EJ, Davis NW, Lim A, Dimalanta ET, Potamousis KD, Apodaca J, Anantharaman TS, Lin J, Yen G, Schwartz DC, Welch RA, Blattner FR. Genome sequence of enterohaemorrhagic Escherichia coli O157:H7. Nature. 2001 Jan 25;409(6819):529-33.

Plunkett G 3rd, Rose DJ, Durfee TJ, Blattner FR. Sequence of Shiga toxin 2 phage 933W from Escherichia coli O157:H7: Shiga toxin as a phage late-gene product. J Bacteriol. 1999; 181:1767-78.

Pope WH, Weigele PR, Chang J, Pedulla ML, Ford ME, Houtz JM, Jiang W, Chiu W, Hatfull GF, Hendrix RW, King J. Genome sequence, structural proteins, and capsid organization of the cyanophage Syn5: a "horned" bacteriophage of marine synechococcus. J Mol Biol. 2007; 368(4):966-81.

Purcell AH, Hopkins DL. Fastidious xylem-limited bacterial plant pathogens. Annu Rev Phytopathol. 1996; 34:131-51.

Recktenwald J, Schmidt H. The nucleotide sequence of Shiga toxin (Stx) 2e-encoding phage phiP27 is not related to other Stx phage genomes, but the modular genetic structure is conserved. Infect Immun. 2002; 70:1896-908.

Resch G, Kulik EM, Dietrich FS, Meyer J. Complete genomic nucleotide sequence of the temperate bacteriophage Aa Phi 23 of Actinobacillus actinomycetemcomitans. J Bacteriol. 2004; 186(16):5523-8.

Roberts SJ, Eden-Green SJ, Jones P, Ambler DJ. Pseudomonas syzygii, sp.nov., the cause of Sumatra disease of cloves. Syst Appl Microbiol. 1990; 13:34-43.

Rohwer F, Edwards R. The Phage Proteomic Tree: a genome-based taxonomy for phage. J Bacteriol. 2002; 184(16):452935.

Röske K, Calcutt MJ, Wise KS. The Mycoplasma fermentans prophage phiMFV1: genome organization, mobility and variable expression of an encoded surface protein. Mol Microbiol. 2004; 52(6):1703-20.

Rossetti V, Garnier M, Beretti MJ, Teixeira ARR, Quaggio JA, Battaglia OC, Gomes MP, De Negri JD. Resultados preliminares de estudos sobre uma nova anormalidade dos citros observada nos Estados de São Paulo e Minas Gerais. Summa Phytopathol. 1990; 16:13.

Saitou N, Nei M. The neighbor-joining method: a new method for reconstructing phylogenetic trees. Mol Biol Evol. 1987; 4(4):406-25. 
Sakaguchi Y, Hayashi T, Kurokawa K, Nakayama K, Oshima K, Fujinaga Y, Ohnishi M, Ohtsubo E, Hattori M, Oguma $\mathrm{K}$. The genome sequence of Clostridium botulinum type $\mathrm{C}$ neurotoxin-converting phage and the molecular mechanisms of unstable lysogeny. Proc Natl Acad Sci U S A. 2005; 102(48):17472-7.

Sakharkar KR, Dhar PK, Chow VT. Genome reduction in prokaryotic obligatory intracellular parasites of humans: a comparative analysis. Int J Syst Evol Microbiol. 2004; 54(Pt 6):1937-41.

Sanger F, Coulson AR, Hong GF, Hill DF, Petersen GB. Nucleotide sequence of bacteriophage lambda DNA. J Mol Biol. 1982; 162(4):729-73.

Sato T, Shimizu T, Watarai M, Kobayashi M, Kano S, Hamabata T, Takeda Y, Yamasaki S. Genome analysis of a novel Shiga toxin 1 (Stx1)-converting phage which is closely related to Stx2-converting phages but not to other Stx1-converting phages. J Bacteriol. 2003; 185:3966-71.

Schultz HR, Matthews M. Resistance to water transport in shoots of Vitis vinifera L. Plant Physiol. 1988; 88:718-724.

Setubal JC, Werneck R. A program for building contig scaffolds in double-barrelled shotgun genome sequencing. Institute of Computing Technical report IC-01-05, Unicamp, 2001.

Simpson AJ, Reinach FC, Arruda P, Abreu FA, Acencio M, Alvarenga R, Alves LM, Araya JE, Baia GS, Baptista CS, Barros MH, Bonaccorsi ED, Bordin S, Bové JM, et al., The genome sequence of the plant pathogen Xylella fastidiosa. Nature. 2000; 406(6792):151-7.

Smith MC, Thorpe HM. Diversity in the serine recombinases. Mol Microbiol. 2002; 44: 299-307.

Sonnhammer EL, Eddy SR, Durbin R. Pfam: a comprehensive database of protein domain families based on seed alignments. Proteins. 1997; 28(3):405-20.

Stein LY, Arp DJ, Berube PM, Chain PS, Hauser L, Jetten MS, Klotz MG, Larimer FW, Norton JM, Op den Camp HJ, Shin M, Wei X. Whole-genome analysis of the ammonia-oxidizing bacterium, Nitrosomonas eutropha C91: implications for niche adaptation. Environ Microbiol. 2007 Dec;9(12):2993-3007.

Strauss EJ, Falkow S. Microbial pathogenesis: genomics and beyond. Science. 1997; 276(5313):707-12.

Sullivan JT, Ronson CW. Evolution of rhizobia by acquistion of a $500 \mathrm{~kb}$ symbiosis island that integrates into a phe-tRNA gene. Proc Natl Acad Sci USA. 1998; 95:5145-5149.

Sullivan MB, Coleman ML, Weigele P, Rohwer F, Chisholm SW. Three Prochlorococcus cyanophage genomes: signature features and ecological interpretations. PLoS Biol. 2005; 3(5):e144.

Summer EJ, Gonzalez CF, Bomer M, Carlile T, Embry A, Kucherka AM, Lee J, Mebane L, Morrison WC, Mark L, King MD, LiPuma JJ, Vidaver AK, Young R. Divergence and mosaicism among virulent soil phages of the Burkholderia cepacia complex. J Bacteriol. 2006 Jan;188(1):255-68.

Syvanen M. Horizontal gene transfer: evidence and possible consequences. Annu Rev Genet. 1994; 28:237-61.

Tanaka K, Nishimori K, Makino S, Nishimori T, Kanno T, Ishihara R, Sameshima T, Akiba M, Nakazawa M, Yokomizo Y, Uchida I. Molecular characterization of a prophage of Salmonella enterica serotype Typhimurium DT104. J Clin Microbiol. 2004; 42(4):1807-12.

Tauschek M, Strugnell RA, Robins-Browne RM. Characterization and evidence of mobilization of the LEE pathogenicity island of rabbit-specific strains of enteropathogenic Escherichia coli. Mol Microbiol. 2002; 44(6):1533-50.

Thompson JD, Higgins DG, Gibson TJ. CLUSTAL W: improving the sensitivity of progressive multiple sequence alignment through sequence weighting, position-specific gap penalties and weight matrix choice. Nucleic Acids Res. 1994; 22(22):4673-80.

Treangen T, Messeguer X. M-GCAT: interactively and efficiently constructing large-scale multiple genome comparison frameworks in closely related species. BMC Bioinformatics. 2006; 7:433.

Tremblay DM, Moineau S. Complete genomic sequence of the lytic bacteriophage DT1 of Streptococcus thermophilus. Virology. 1999; 255(1):63-76.

Tyson GE, Stojanovic BJ, Kuklinski RF, Divittorio TJ, Sullivan ML. Scanning electron microscopy of Pierce's disease bacterium in petiolar xylem of grape leaves. Phytopathology. 1985; 75:264-269. 
van der Wilk F, Dullemans AM, Verbeek M, van den Heuvel JF. Isolation and characterization of APSE-1, a bacteriophage infecting the secondary endosymbiont of Acyrthosiphon pisum. Virology. 1999; 262(1):104-13.

Van Sluys MA, de Oliveira MC, Monteiro-Vitorello CB, Miyaki CY, Furlan LR, Camargo LE, da Silva AC, Moon DH, Takita MA, Lemos EG, Machado MA, Ferro MI, et al., Comparative analyses of the complete genome sequences of Pierce's disease and citrus variegated chlorosis strains of Xylella fastidiosa. J Bacteriol. 2003; 185(3):1018-26.

Van Sluys MA, Monteiro-Vitorello CB, Camargo LE, Menck CF, Da Silva AC, Ferro JA, Oliveira MC, Setubal JC, Kitajima JP, Simpson AJ. Comparative genomic analysis of plant-associated bacteria. Annu Rev Phytopathol. 2002; 40:169-89.

Vodovar N, Vallenet D, Cruveiller S, Rouy Z, Barbe V, Acosta C, Cattolico L, Jubin C, Lajus A, Segurens B, Vacherie B, Wincker P, Weissenbach J, Lemaitre B, Médigue C, Boccard F. Complete genome sequence of the entomopathogenic and metabolically versatile soil bacterium Pseudomonas entomophila. Nat Biotechnol. 2006 Jun;24(6):673-9.

Voelker LL, Dybvig K. Sequence analysis of the Mycoplasma arthritidis bacteriophage MAV1 genome identifies the putative virulence factor. Gene. 1999; 233(1-2):101-7.

Waddell TE, Poppe C. Construction of mini-Tn10luxABcam/Ptac-ATS and its use for developing a bacteriophage that transduces bioluminescence to Escherichia coli O157:H7. FEMS Microbiol Lett. 2000; 182(2):285-9.

Weinbauer MG. Ecology of prokaryotic viruses. FEMS Microbiol Rev. 2004; 28:127-81.

Wells JM, Raju BC, Jung HY, Weisburg WG, Mandelco-Paul L, Brenner DJ. Xylella fastidiosa, new-genus, new-species gram negative xylem-limited fastidious plant bacteria related to Xanthomonas spp. Int J Syst Bacteriol. 1987; 37(2): 136143.

Wheeler DL, Barrett T, Benson DA, Bryant SH, Canese K, Chetvernin V, Church DM, DiCuccio M, Edgar R, Federhen S, Geer LY, Kapustin Y, Khovayko O, Landsman D, Lipman DJ, Madden TL, Maglott DR, Ostell J, Miller V, Pruitt KD, Schuler GD, Sequeira E, Sherry ST, Sirotkin K, Souvorov A, Starchenko G, Tatusov RL, Tatusova TA, Wagner L, Yaschenko E. Database resources of the National Center for Biotechnology Information. Nucleic Acids Res. 2007; 35 :D512.

Whittam TS, Reid SD, Selander RK. Mutators and long-term molecular evolution of pathogenic Escherichia coli O157:H7. Emerg Infect Dis. 1998; 4(4):615-7.

Williams BJ, Golomb M, Phillips T, Brownlee J, Olson MV, Smith AL. Bacteriophage HP2 of Haemophilus influenzae. J Bacteriol. 2002; 184(24):6893-905.

Williams KP. Integration sites for genetic elements in prokaryotic tRNA and tmRNA genes: sublocation preference of integrase subfamilies. Nucleic Acids Res. 2002; 30(4):866-75.

Wong K, Golding GB. A phylogenetic analysis of the pSymB replicon from the Sinorhizobium meliloti genome reveals a complex evolutionary history. Can J Microbiol. 2003; 49(4):269-80.

Woods DE, Jeddeloh JA, Fritz DL, DeShazer D. Burkholderia thailandensis E125 harbors a temperate bacteriophage specific for Burkholderia mallei. J Bacteriol. 2002; 184(14):4003-17.

Xu Z, Zhou Y, Li L, Zhou R, Xiao S, Wan Y, Zhang S, Wang K, Li W, Li L, Jin H, Kang M, Dalai B, Li T, Liu L, Cheng Y, Zhang L, Xu T, Zheng H, Pu S, Wang B, Gu W, Zhang XL, Zhu GF, Wang S, Zhao GP, Chen H. Genome biology of Actinobacillus pleuropneumoniae JL03, an isolate of serotype 3 prevalent in China. PLoS ONE. 2008 Jan 16;3(1):e1450.

Zhang XX, Deng Q, Zhang SY, Liu J, Cai Q, Lu ZM, Wang Y. Broadly cross-reactive mimotope of hypervariable region 1 of hepatitis C virus derived from DNA shuffling and screened by phage display library. J Med Virol. 2003; 71(4):511-7.

Zomorodipour A, Andersson SG. Obligate intracellular parasites: Rickettsia prowazekii and Chlamydia trachomatis. FEBS Lett. 1999; 452(1-2):11-5. 
ANEXOS 


\section{ANEXO I - ANÁLISE DA MONTAGEM DE Xf-AL E Xf-OL}

Xf-AL e Xf-OL apresentam seu genoma montado em um único contig, sendo que não foi realizado o procedimento de finalização de montagem; portanto, regiões que apresentavam GAPs foram fechadas com a inclusão de "NNs" e regiões que apresentavam baixa cobertura de reads não foram inspecionadas a fim de melhorar a qualidade. O resultado final é a apresentação de dois rascunhos do genoma, denominados de moléculas candidatas para cada genoma. Os principais resultados das montagens estão na tabela 9.1 .

Tabela 9.1. Dados da montagem das moléculas candidatas de Xf-OL e Xf-AL

\begin{tabular}{l|l|l}
\hline & Xf-OL $(*)$ & Xf-AL \\
\hline Tamanho (pb) & 2.617 .604 & 2.629 .797 \\
Índice de erro (a cada 10 kb) & 18.90 & 21.75 \\
\% do genoma Seqüenciado & $\sim 99,77 \%$ & $\sim 99,62 \%$ \\
Quantidade e \% de NNs incluídos & $\sim 6.000 \mathrm{pb} / 0,23 \%$ & $\sim 10.000 \mathrm{pb} / 0,38 \%$ \\
Regiões relacionadas a profagos & 10 & 11 \\
Regiões remanescentes de profagos & 01 & 03 \\
tRNAs & 49 & 49 \\
Total de ORFs $(*)$ & 2.576 & 2.546 \\
\hline
\end{tabular}

(*) Procedimentos realizados em colaboração com equipe de bioinformática do LNCC (materiais e métodos)

A fim de dar suporte à montagem das moléculas candidatas, duas análises computacionais foram realizadas: (a) Estudo de posicionamento das pontas de BACs seqüenciadas (vide Materiais e Métodos), e (b) análise GC-Skew. A análise de pontas de BACs está implementada na interface phage-navigator, onde através de mapas genômicos a cobertura das pontas de BACs pode ser visualizada frente à molécula candidata (http://gracilaria.ib.usp.br/integraseDB). A figura 9.1 ilustra de forma compacta a cobertura de pontas de BACs nas duas moléculas candidatas.

A molécula candidata de Xf-AL apresenta 763.498 pb cobertos por pontas de BACs, o que representa $30 \%$ de sua molécula; apresenta 157 GAPs, sendo que 52 (31\%) estão cobertos por pontas de BACs. A montagem de Xf-OL apresenta 1.550 .543 pb cobertos por pontas de BACs, ou 57\% de sua molécula; apresenta 82 GAPs, sendo que 29 (35\%) estão cobertos por pontas de BACs. Os resultados desta análise apenas servem como suporte para a montagem das moléculas candidatas de Xf-AL e Xf-OL 
A)

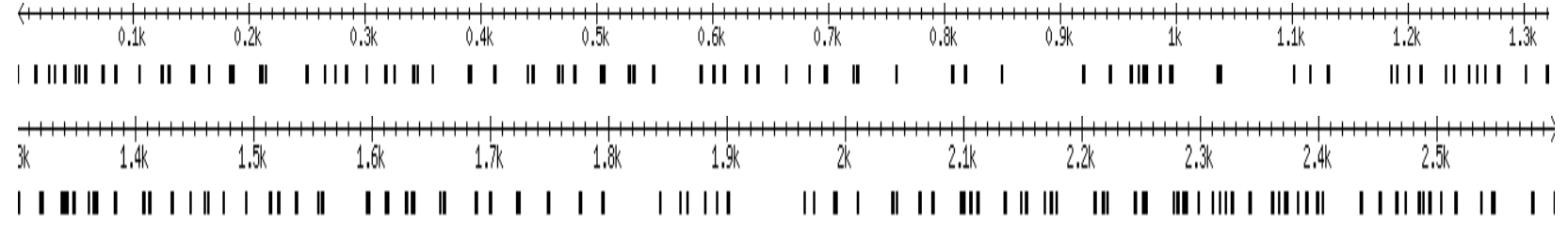

B)

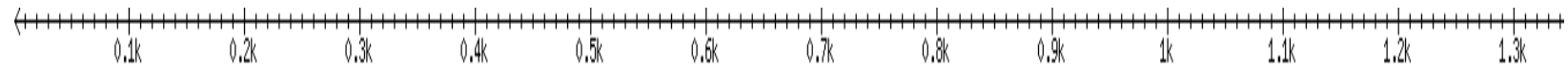

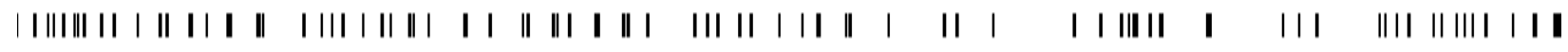

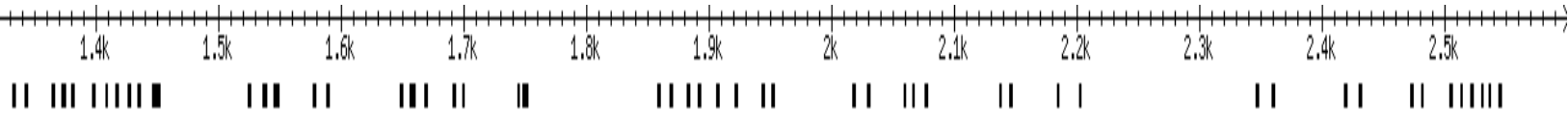

Figura 9.1 Distribuição das pontas de BACs nas moléculas candidatas de Xf-AL (A) e Xf-OL (B). A linha superior com escala de tamanho (em $\mathrm{kb}$ ) representa a molécula candidata, enquanto que os retângulos pretos localizados abaixo das linhas representam as pontas de BACs.

Um segundo método de análise da montagem foi empregado. A metodologia de GCSkew é empregada para estudos de identificação de origem e término de replicação em genomas procariontes. Porém, com base no seqüenciamento completo de Xf-CVC e Xf-PD, esta metodologia pode ser utilizada para identificar não só origem e término de replicação em Xf-OL e Xf-AL, como também para análise comparativa do padrão de seu gráfico. O gráfico de GCSkew representa uma informação valiosa no estudo da consistência da montagem de genomas, particularmente quando comparados a gráficos de genomas já publicados (Arakawa et al., 2007). A figura 9.2 ilustra os gráficos de GC-Skew de Xf-OL e Xf-AL comparados aos gráficos de XfCVC e Xf-PD.

Pela figura, nota-se similaridade entre os gráficos de Xf-PD com Xf-OL e Xf-CVC com $\mathrm{Xf}-\mathrm{AL}$ respectivamente, indicando que as moléculas candidatas apresentam padrão de GC-Skew compatível com as outras linhagens de Xf. É possível identificar a região de término de replicação aproximadamente nas posições $1.1 \mathrm{Mb}(\mathrm{A}), 1.05$ (B), 1.7 Mb (C) e 1.7 Mb (D). Os resultados do GC-Skew, associados ao estudo de posicionamento das pontas de BAC, refletem a coerência das montagens das moléculas candidatas de Xf-OL e Xf-AL. Porém, estes resultados não excluem as metodologias de biologia molecular, como, por exemplo, o seqüenciamento completo de BACs, como método confirmatório para a montagem de genoma (Fleischmann et al., 1995). 

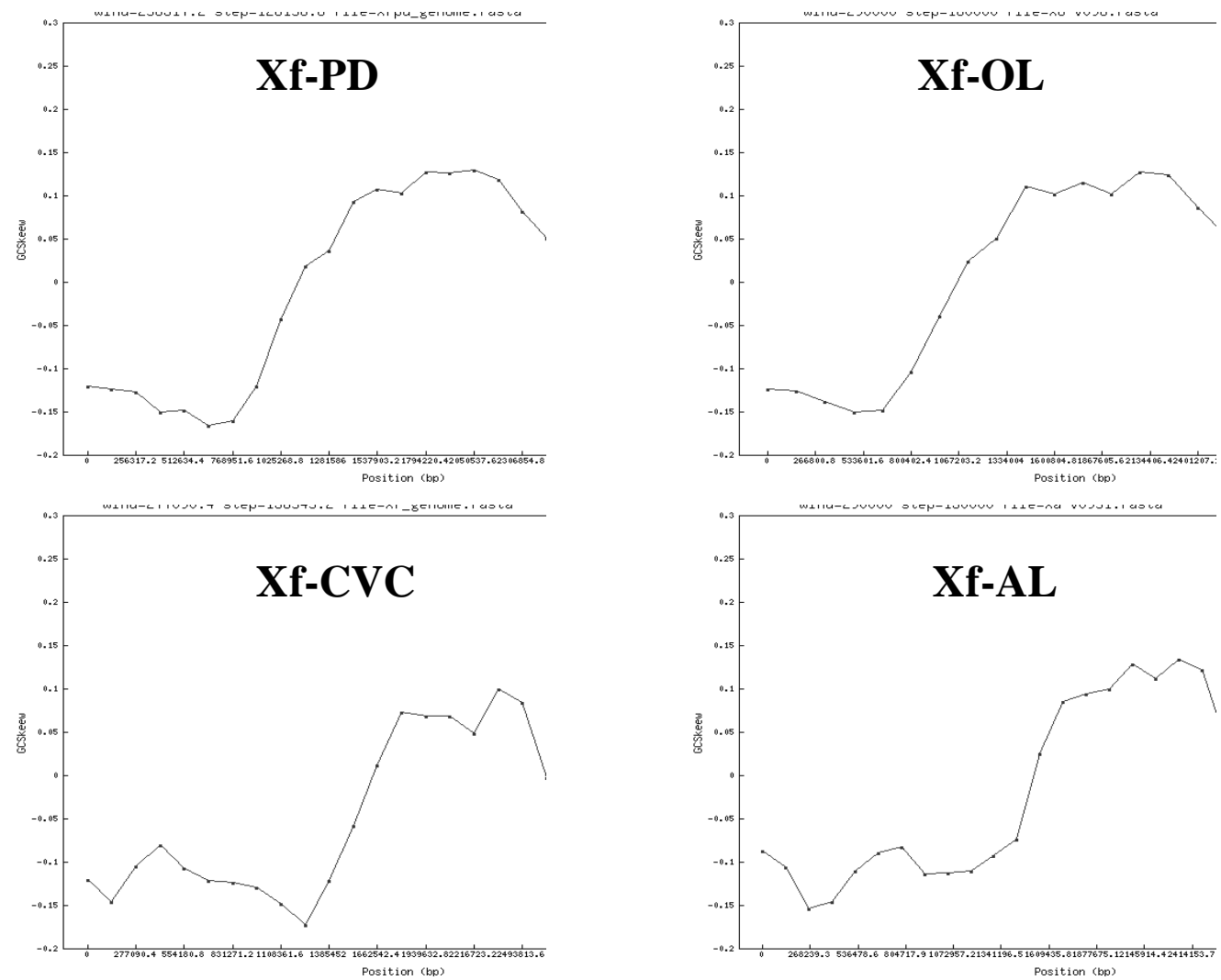

Figura 9.2 Estudo comparativo de GC-Skew entre as quatro linhagens de Xf. Os parâmetros para o cálculo foram: Delta $5 \%$ e Janela $10 \%$ em relação ao comprimento da seqüência. O ponto de início do gráfico equivale à região de origem de replicação (dnaA). Eixo "X", tamanho do genoma; eixo "Y", polaridade GC.

\section{REFERÊNCIAS BIBLIOGRÁFICAS}

Arakawa K, Saito R, Tomita M. Noise-reduction filtering for accurate detection of replication termini in bacterial genomes. FEBS Lett. 2007; 581(2):253-8.

Fleischmann RD, Adams MD, White O, Clayton RA, Kirkness EF, Kerlavage AR, Bult CJ, Tomb JF, Dougherty BA, Merrick JM, et al. Whole-genome random sequencing and assembly of Haemophilus influenzae Rd. Science. 1995; 269(5223):496-512. 
Figura II.A: Integrases identificadas nas quatro linhagens de Xf (CLUSTALX 2.0). As caixas de texto indicam a posição do ramos no alinhamento. $\begin{array}{llllllllll}10 & 20 & 30 & 40 & 50 & 60 & 70 & 80 & 90 & 100\end{array}$ $\mathrm{CVC}_{-1} \mathrm{r} 1$

xop 7 frag

xap10 frag

xop 6

xap4

xpd3

xop8

xpd1
xap2

xap7

xap3
xfp4
xpd4

$\mathrm{xpd} 4$
ol $\mathrm{r} 1$

ol_r

xap6

xpd2

$x f p 5$

pd_r1

$x f \mathrm{p} 2$

xop4
$x f p 3$ FS

xop3

xop10

al_r2_FS

CVC_r ${ }^{4}$

xpd $\overline{6}$ FS

xop2

xpd1_2

xap4-2

$x f p 6$

xop8_FS

xop7 7 - FS

xpd8

xop6 2

xpd7

xop 9

xfe1 2 f frag

xap $\overline{5}$

xap9_FS

xap5_frag

xap9

xop5

giCVC

giPD

giCVC_frag

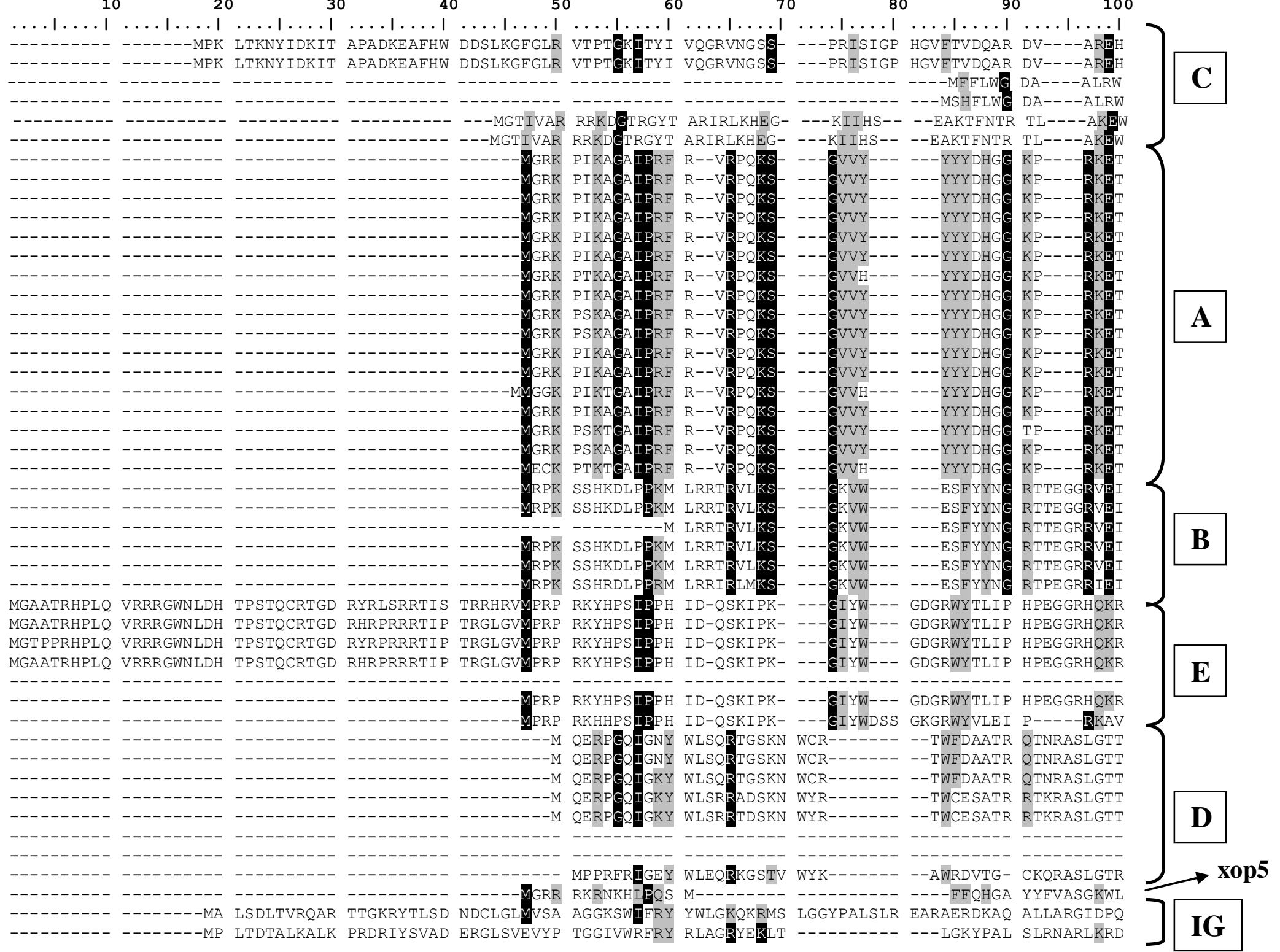


Cvc_r1

al-ro

xop7 frag

xap10 frag

xop 6 - 1

xpd3

xop8

xpd1

xap2

xap7

xap3
$x f p 4$

xpd4

$x p d 4$
ol 11

xap6

xap6

xap1

xpd2

$x$ f5

pd_r1

$x$ fp2

$x \circ p 4$
$x f p 3$ FS

xop3

xop 10
al 22 FS

CVC $r \overline{4}$

xpd $\overline{6}$ FS

xop2

xpd1_2

xap4_2

xfp 6

xop8_FS

xop 8 FS
xop7 FS

xop7 7 FS
xpd8 FS

xop $6^{-} 2$

xop6 2

xpd7_ES

xopg

xfp1 2 frag

xap $\overline{5}$

xap9_FS

xap5-frag

xap9

xop5

giCVC

giPD

giCVC_frag

110

120

130

140

150

160

170

180

190

200

LRSMRMGIDP RAVAKKEAAQ RVTLRDVADG YKRDRPLKDS SKAEIERHVT TTFEAWLKKP LRDITREMVT KRFNEIKNHG LRGNGLRSMRMGIDL RAVAKKEAAQ RVTLRDVADG YKRDRPLKDS SKAEIERHVT TTFEAWLKKP LKDINREAVT KRFNEIKTKG TTGNG---- --------LSEKSRKTTA HEDVAK---- -- LRWLASH FD----GKK- - - - - - - - LAAIDS-- - - - - - - - DLILRVAT LKAAE-LSEKSRKATA HEDAAK---- ---LRWLASY FA--- GKK- - -

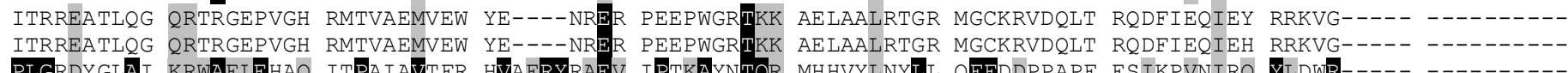

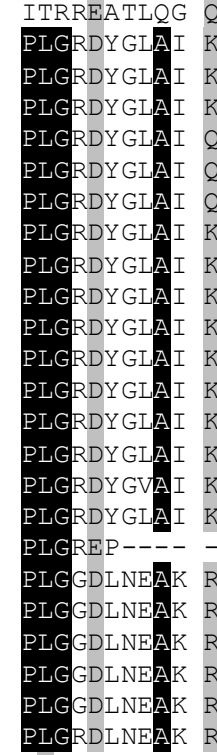

TIAGRAARLS DLH

TIAGRGARLS DLHA

-MAGRAARLS DLHA

AVAGPSALLS DLHSIMEARS GTHERGTIGH VITHYLRSTD FQRLAP

DIQEAKVRLW F

DIQEAKVRLW E

DIQEAKVRLW EWY

DIQEAKIRLC LWYAKHGDVS KQTPQDILLD

-MQEAKVRT

NOPPTNVLLS TVITRYMTOH

$\begin{array}{llll}\text { PLGKEYGAAL GKYAVFVGKK } & ---P T V D S V K & \text { DMVWGYIEAK RPKLSAKTIE GYERNAANLC AVEGHLRP-- DEIETSDIFR YLTTKG } \\ \text { IERDQRRHAA KLAGEYTFKN VFDAWVEHRR KELKEGRQST LSQILRIFNK DVLPTLGKMS IYDIRRPQLV GVVAAIEKRK AFTTAEKVRT WFNQMFRYAL }\end{array}$ IERDQRRH

$$
\text { HAA KLAGEYTFKN VFDAWVEHRR KELKEGR }
$$

- - - - M PTAIEFIADR LPRVTVEDVR RFARFFREI

APAFAAEI M PRRYLDKDIL

YDIRRPQLV GVVAAIEKRK AFTTAEKVRT WFNQMFRYA
FVGDKPMRE VTAEEIRSLI WRKKEQ--$\begin{array}{lll}\text { MHHVYLNYLL QFEDDPPAPF } & \text { ESIKPVNIRQ } \\ \text { MHHVYLNYLL OFFDDPPAPF } & \text { ESIKPVNIRQ }\end{array}$ MHHVYLNY $\begin{array}{ll}\text { DDPPAPF } & \text { ESIKPVNIRQ } \\ \text { DDPPAPF } & \text { ESIKPVNIRQ }\end{array}$ DDPPAPF ESIKPVNIRQ DDPPAPF ESIKPVNIRQ DDPPAPF EAIKPVNIRQ DDPPAPF EAIKPVNIRQ DDPPAPF EAIKPVNIRQ DDPPAPF EAIKPVNIRO DPPAPF EATPVNVR DDPPAPF ESIKPVNIRO $\begin{array}{lll} & \\ \text { GDVN--I } & \text { HTVTPQQLAO }\end{array}$ GDVN--I HTVTPQQLA \begin{tabular}{ll} 
FGDVN--I & HTVTPQQLA \\
FGDVN--I & HTVTPQQLA \\
\hline
\end{tabular} VFDVVN--I DNVTPQHIA

LLKDNTTL GSKAVNRLNV PTWQRLVEVI AQGRPAQGDS LLKDNTTL GSKAVNRLNV PTWQRLVEVI AQGRPAQGDS LLKDNTTL GSKAVNRLNV PTWQ LLKDNTTL GSKAVNRLNV P-DYOWCAQAIO DYQWCAQAIQ

LKDNTTL GSKAVNRLNV PTWORLVEVI AOGRPAQGDS DYHHOVEIVR SYKTTMGMTL DRLYIARMSP AIIORIVEKI AVG-----N KYHALVYIV

-AGATVSEI TPSRQREFVR WLQTGSD--- -----Q
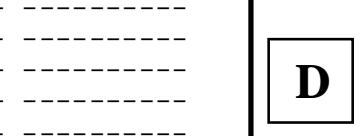
$\underset{x}{\longrightarrow x 55}$ IG 
CVC_r1
al-r3

al-ro 7

xap7 1 frag

xop6 6

xap4-

xpd3

xop8

xpd1

xap2
xap7
xap3

xfp4

xpd4

ol_r 1

xap6
xap1

xap1

xpd2

$x \in \mathrm{p} 5$

pd_r1

$x+\mathrm{p} 2$

xop4 3 Ff 3 FS

xop3

xop 10
al 2 FS

Cve_r 4

xpd $\overline{6}_{-}$FS

xop2

xpd1_2

xap4-2

$x$ fp $6^{-}$

xop8_FS

xop8 8 FS
xop 7 FS

xpd8 FS

xop6_2

xpd7_ES

xops

$\mathrm{xfp} 1$

cvc_r2_frag

xap $\overline{5}$

xap9_FS

xap5 fra

xap9

xop5

giCVC

giCVC_frag

230

240

250

260

270

280

290

300

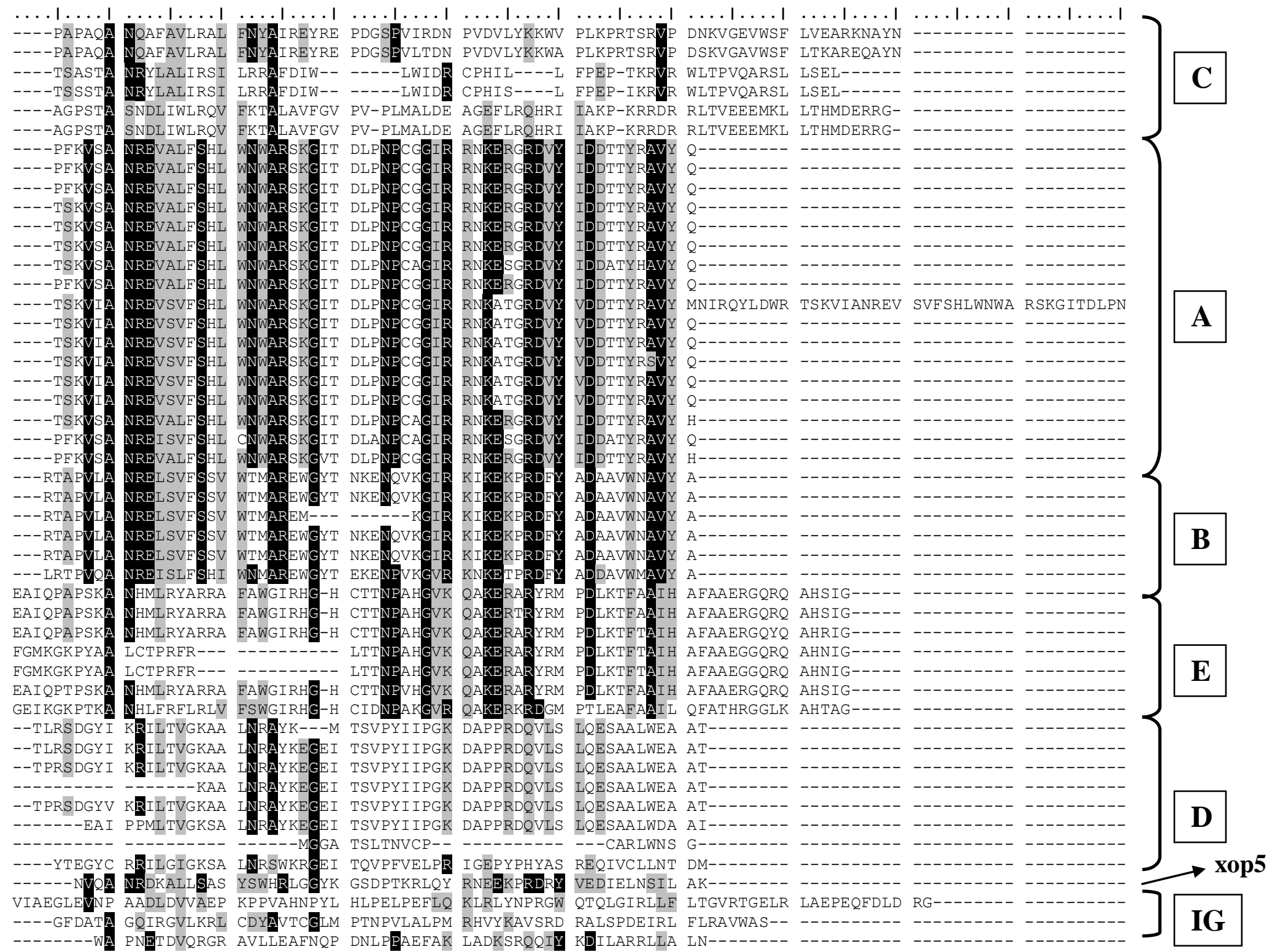




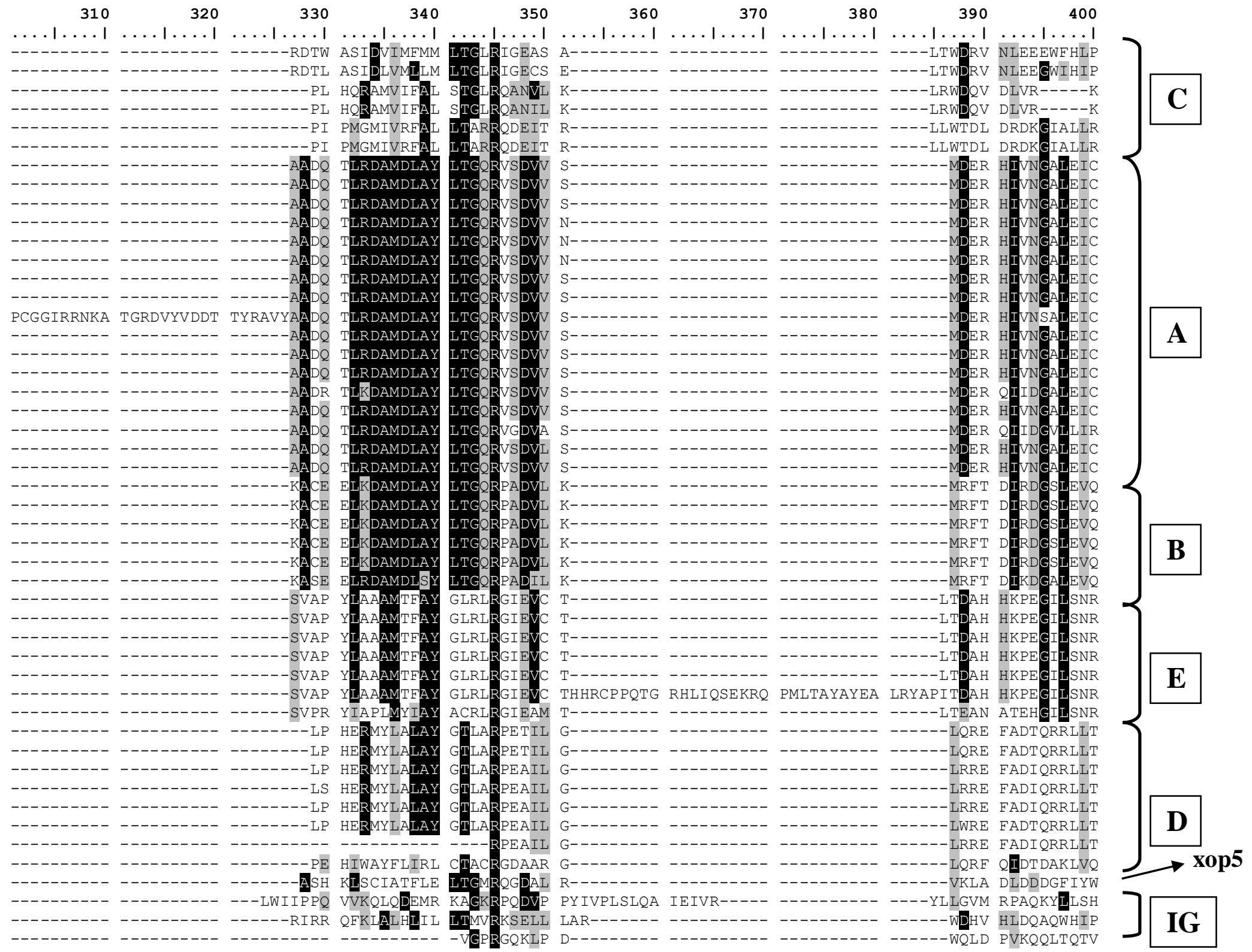


DPKNSNPVWI PLSSQALE-- ----LLKTRP RVKGNPHVFP SWGKSGHIKD PRDFWKKVSE IA---GVHLS NHAMRRTFTQ
DPKNSNPVWL PLSTQAVQ-- ----LLTTRQ RVKGSPFVES SWGKAGHIKD PRDTMKKVSE VA---GTKIT PHDLRRTYTT VLRIP----- - -ADQAKG-- ----RQAIRI PLSLHALQVL QAQRGQHHEW VFTYCGRSIR WV---NTR-- --AWHRALQR
VIRIP---- - - ADQAKG-- ----RQAIRI PLSLPALQVL QAORGQHHEW VFTYCGRSIR WV---NTR-- --AWHQALQR

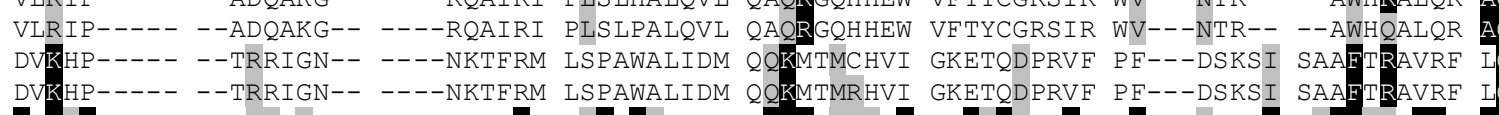

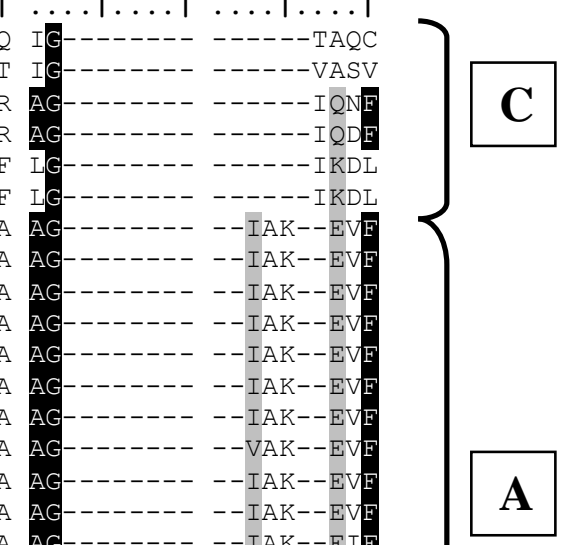

- - -AKLAIT-- ----VTGEI

--VKLAIA-- ----ITGEIA VLIKRIFD-- - RR

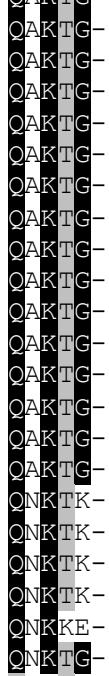

-- VKLAIA-- ---ITGELA VLIKRIFD--
-

-- VKLAIA-- ---ITGELA VLIKRILA--
- VLILA--

- -VKLAIA-

--AKLAIT--

- -AKLAIT-- ---VTGEI

- -AKLAIT-

- -VKLAIA-- ----ITGEI

- -VKLAIA-

- - -AKLAIA-- ----ITGE

- - VKLAIA-- ----ITGEI

- KKLRIL-L EGDGTRTELG

--KKLRIL-L EGDGIRTEL

--KKLRIL-L ESEGIRTE

--KKLRIL-L ERSGIRTE

RKGSR---- --DNITRWND ELRSAWDW

RKGSR---- --DNITRWND ELRSAWD

RKGSR----- --DNITRWND ELRSAWDWL
RKGSR---- - - DNITRWND ELRSAWDW

RKGSR----- --DNITRWND ELRSAWDWL

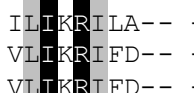

VLIKRIFD-- -

VLIKRIFD--
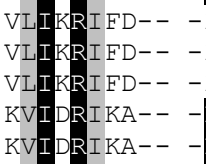

KVT

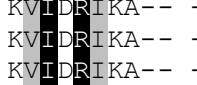

QYRAARWASH

QYRAARWASH K

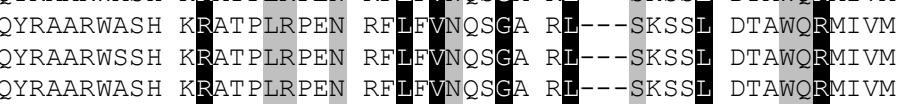

QYRAARWASH KK KI
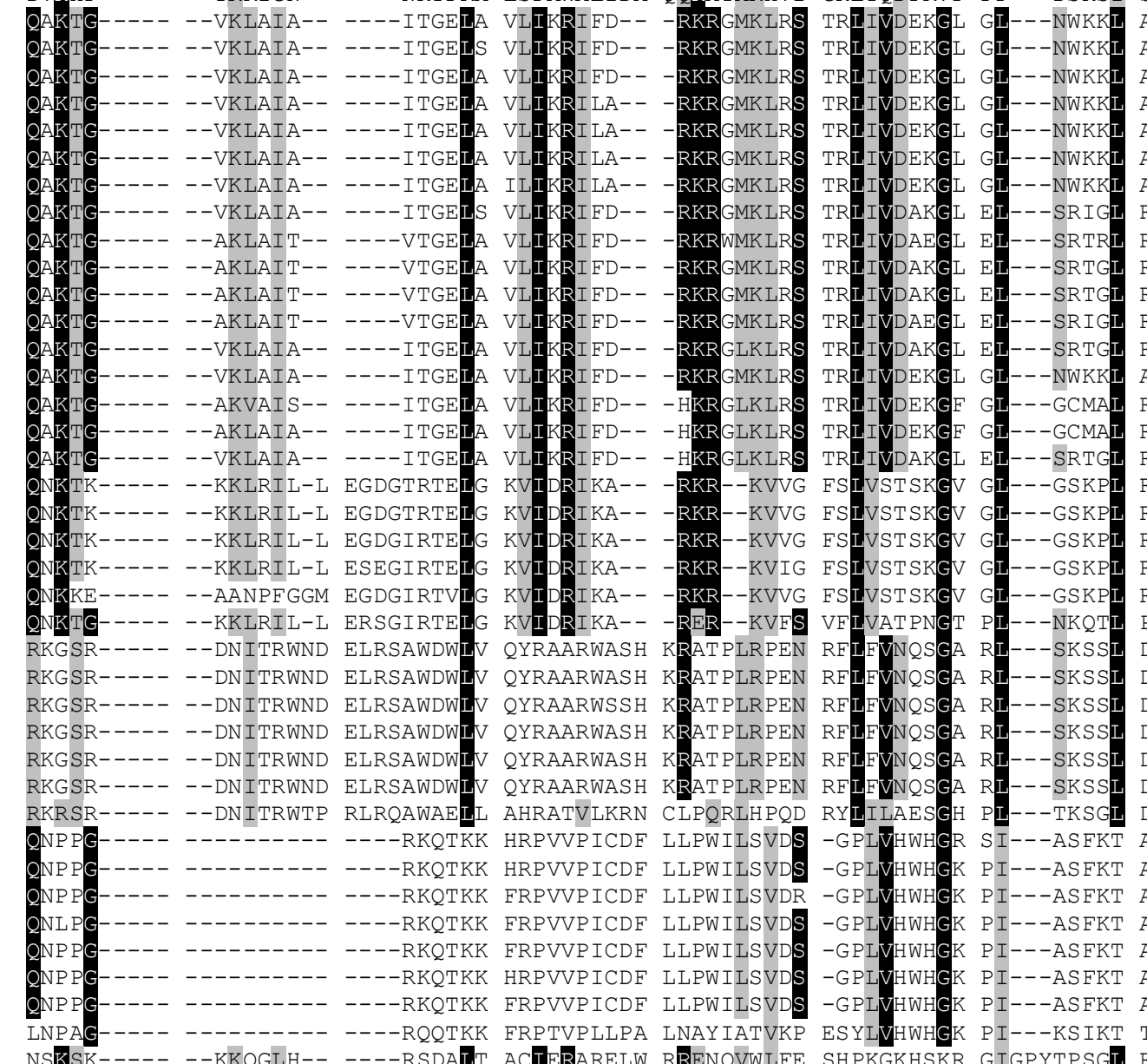

AHRATVLKRN CLPQRLHPQD

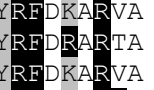

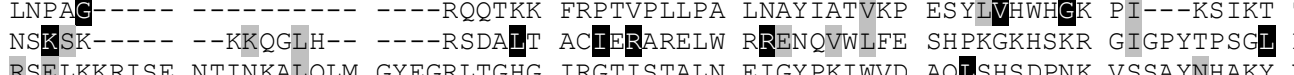
RSELKKRISE NTINKALQLM GYEGRLTGHG IRGTISTALN EIGYPKIWVD AQLSHSDPNK VSSAYNHAKY
AEHSK---LQEVEG-RKQTKK HRPVVPICDF LLPWILSVDS
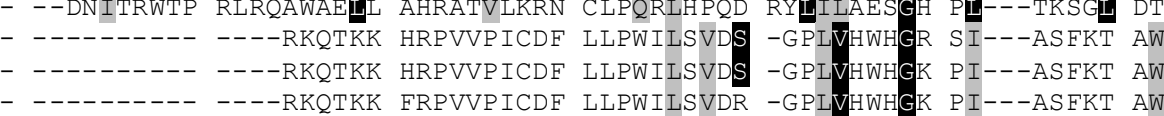

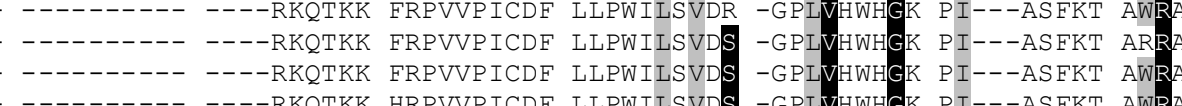
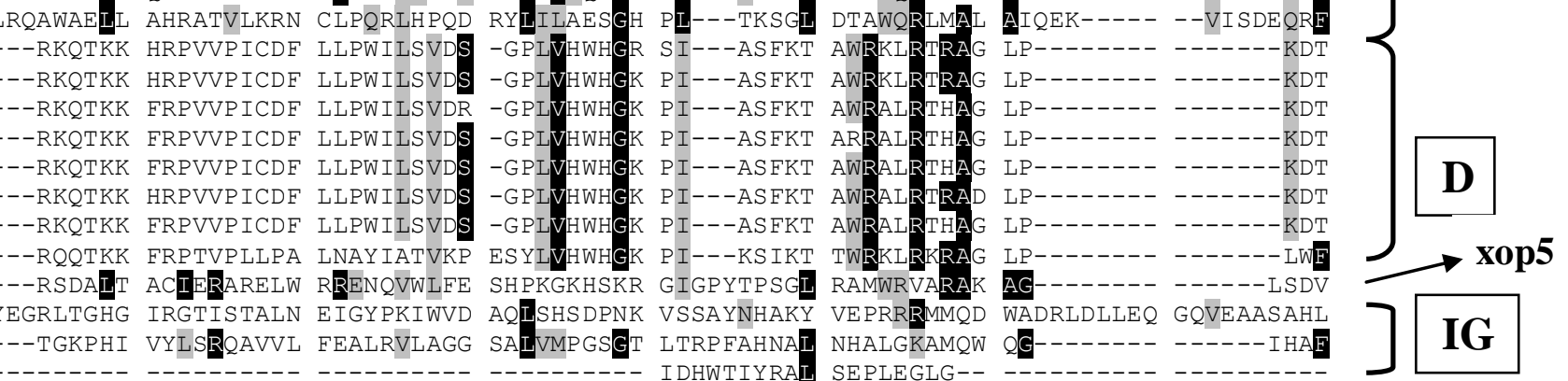


$\begin{array}{rrrrrrrrr}510 & 520 & 530 & 540 & 550 & 560 & 570 & 580 & 590\end{array}$

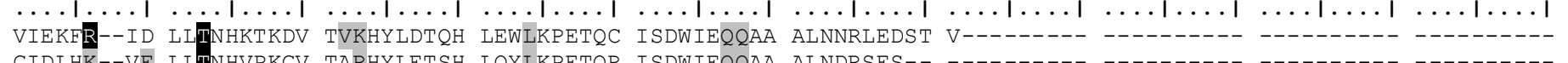
GIDLHK--VE LITNHVPKGV TARHYLETSH LQYLKPETQR ISDWIEQQAA ALNDRSES--

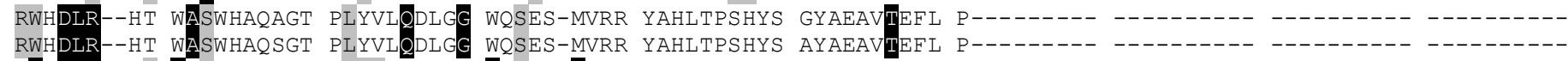
HEHDLR--HE ATSRLFEKGY SIOEVAQFTL HESWT-TLRR YTHLKPEDVP ER-ATIEFL

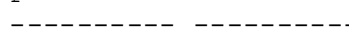

TDKADLAG DMRQAQAQLG HASVTMTEH-

TDKADLAG DMRQAQAQLG HASVTMTEH-

DKADLAG DMRQAQAQLG HASVTMTEH- ---YVRKRK GAKVTPT

DKADLAG DMRQAQAQLG HASVVMTEH- - --YVRKRK GAKVTP

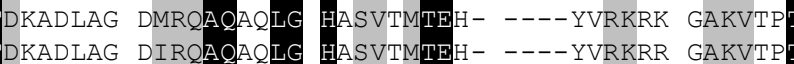

DKADLAG DIRQAQAQLG HASVTMTEH- ----YVRKRR GAKVTPTR-

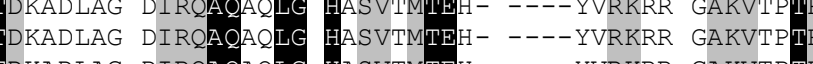

DKADLAG DIRQAQAQLG HASVTMTEH- - --YVRKRR GAKVTPTR

DKADLAG DIRO

TDKADLAG DIRQAQAQLG HTSVVMTEH-

GEGHPSPS AIRACVGDDD GALCTQAQRG EGHAYAVNCG ALPILRSG
ASELP--- -LEHASKLLG HTQQQITQR- ----VYRRV GEIVKPTK--

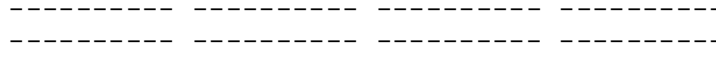

-

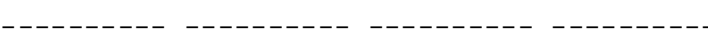

-
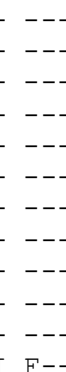

-
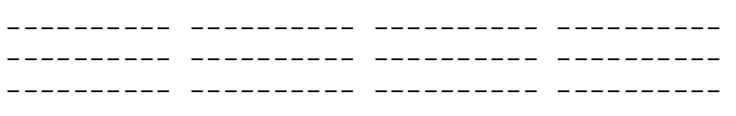
AVRR GAKVTP

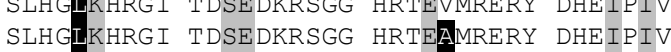

SLHGLKHRGI TDSEDKRSGG HRTEAMRERY NHEVPIV

SLHGLKHRGI TDSEDKRSGG HRTEAMRERY DHEIPIVE

SLHGLKHRGI TDSEDKRSGG HRTEAMRERY DHEIPIVEP
TLHGIKHRGI TDSTDKSSGG HRSESMRORY DHALPIVEP
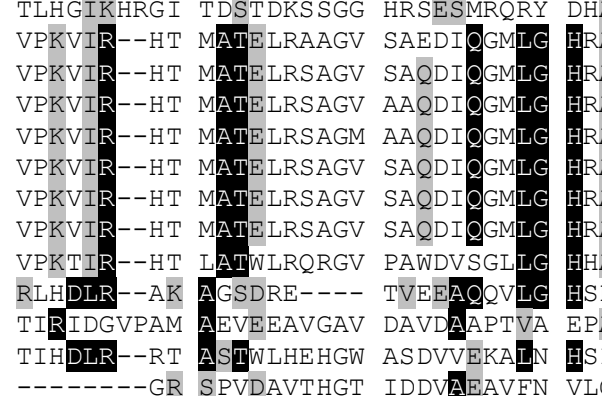

YGGITDV YAKYRPDYMA DAVRAIDAYM GRLRVSCVLA

PKKPG FSRSLHRRY
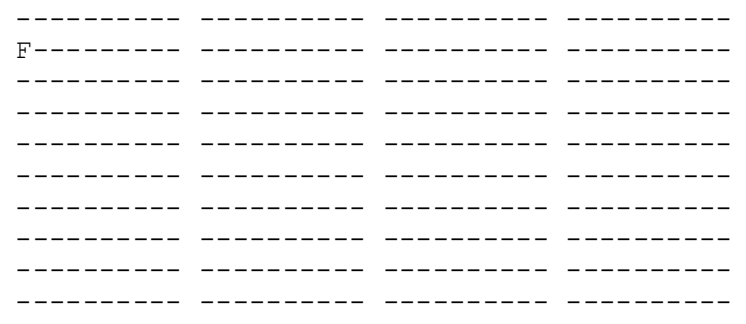

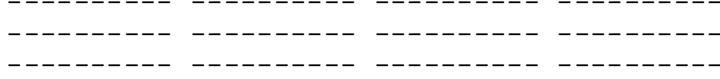
PKKPE FSR -PKKPE F FSR -PKKPE FSRSLHRRYK

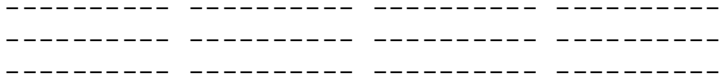

-

-

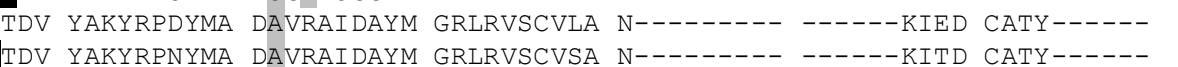
RAYSGITDI YAK--1 AHGGTTDV YTKYRPDYMA DAVRGIDAYM AQLRASO-- AYGGTTDV YAKYRPDYMA DAVRAIDAYM AQLRASCAPV NKPQIMQPID FIGGRCRVRT CDPCR----TDA YAKFDPSYMG AARTALTAIV EELASDVPKL RALLGVNLGS VISFSSASET KKTYNNQYVK DAKVTQR- ----HYRRR MTRVNPTR -

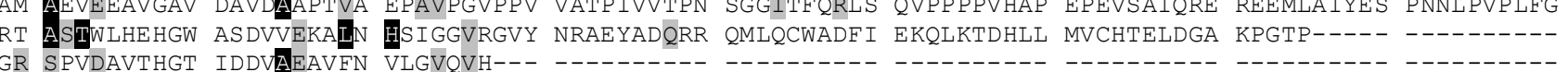

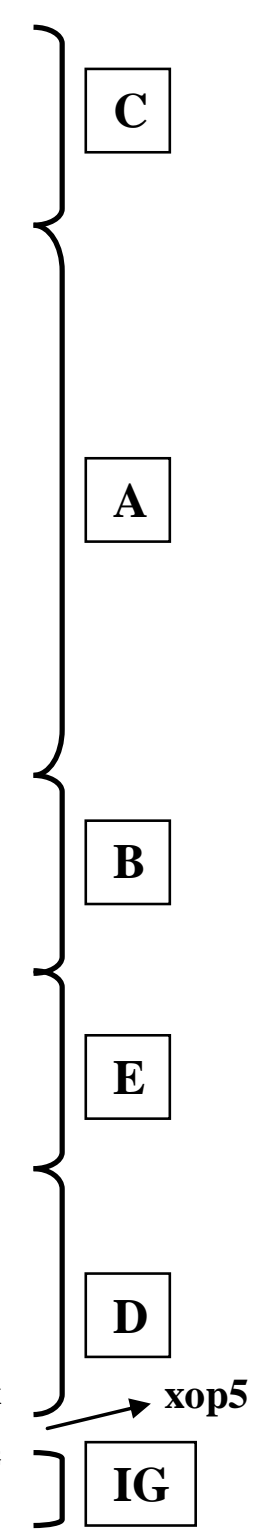


Figura II.B. Alinhamento das integrases classificadas como ramo A. Os aminoácidos preditos como pertencentes aos sítios catalíticos conservados com as demais proteínas da família das tirosinas recombinases são destacados pelas caixas vermelhas. Os sítios catalíticos estão de acordo com a classificação do banco CDD.

ol_r1
xap6
xap1
xpd2
xfp5
pd_r1
xfp2
xop4
xop8_xo087
xpd3
xpd1
xap2
xap7
xap3
xfp4
xpd4
xfp3_Fs
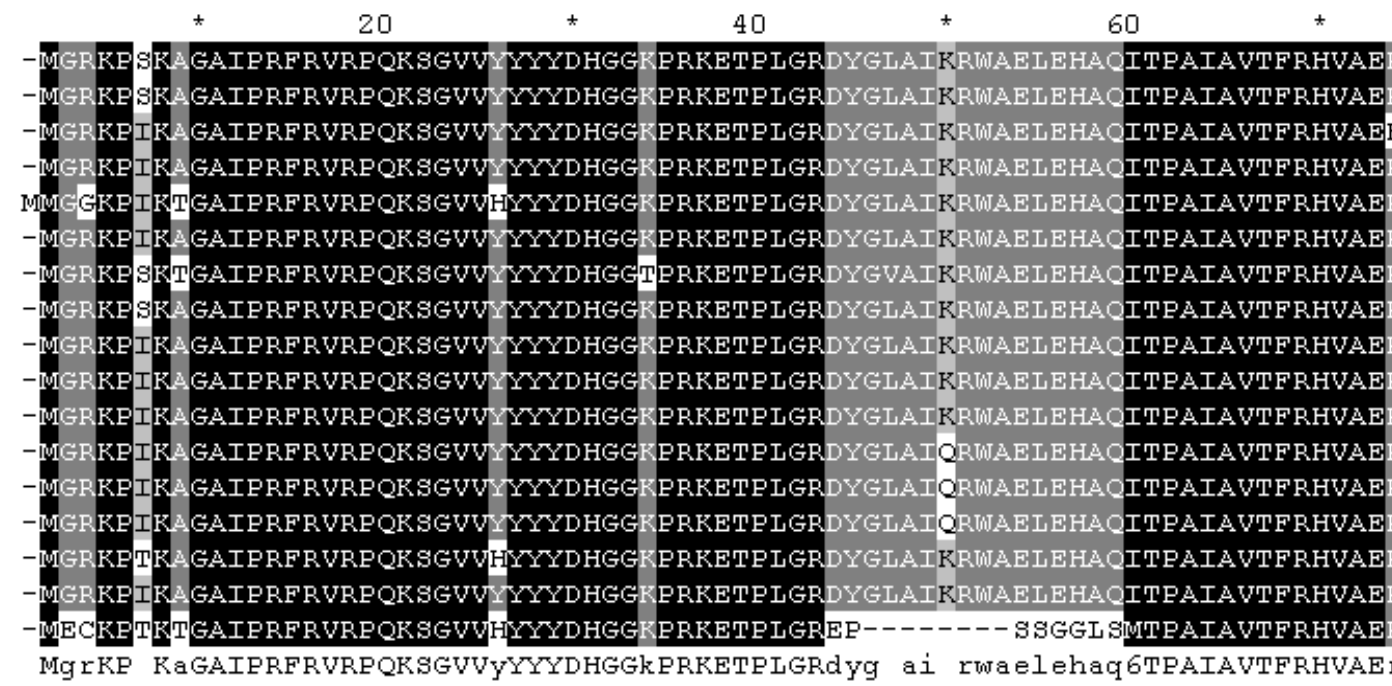

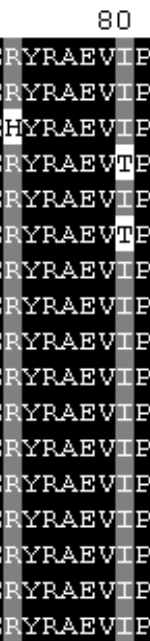
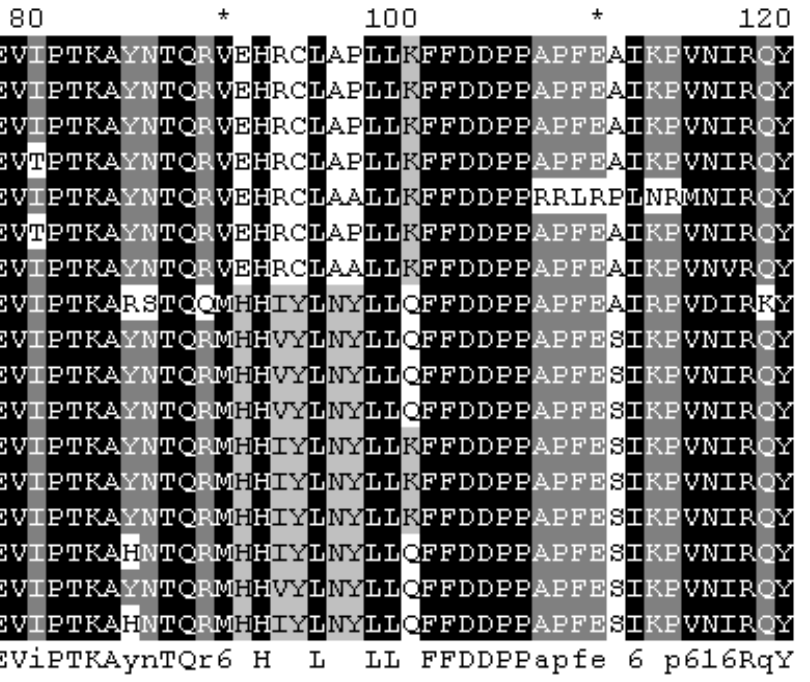

ol_r1
xap6
xap1
xpd2
xfp5
pd_r1
xfp2
xop4
xop8_xo087
xpd3
xpd1
xap2
xap7
xap3
xfp4
xpd4
xfp3_FS

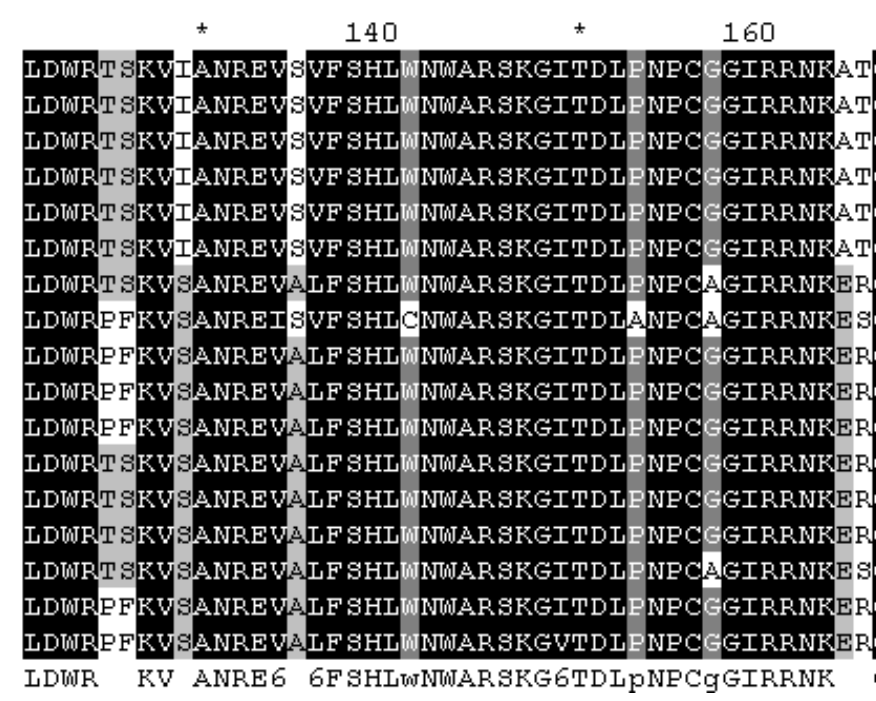

* $180-20$

200

220

240

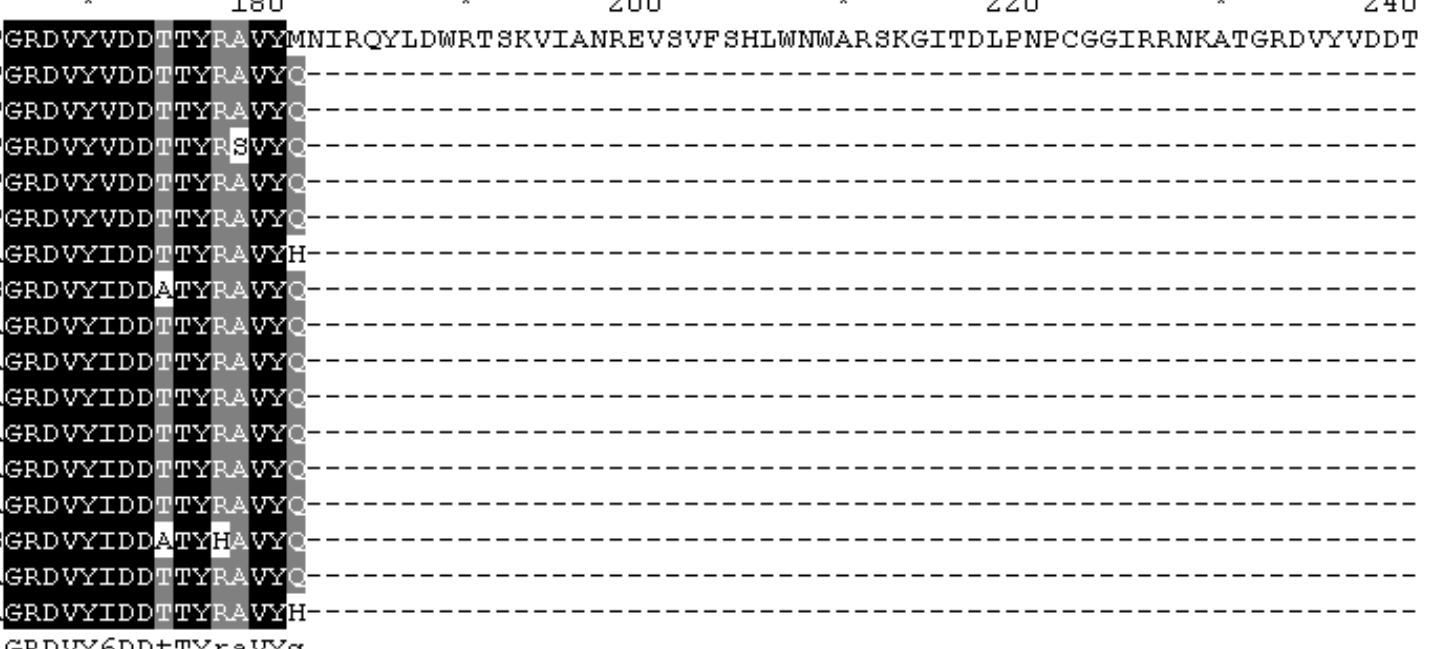

GRDVY6DDtTYraVYq

Continua 
Figura II.B. (continuação)

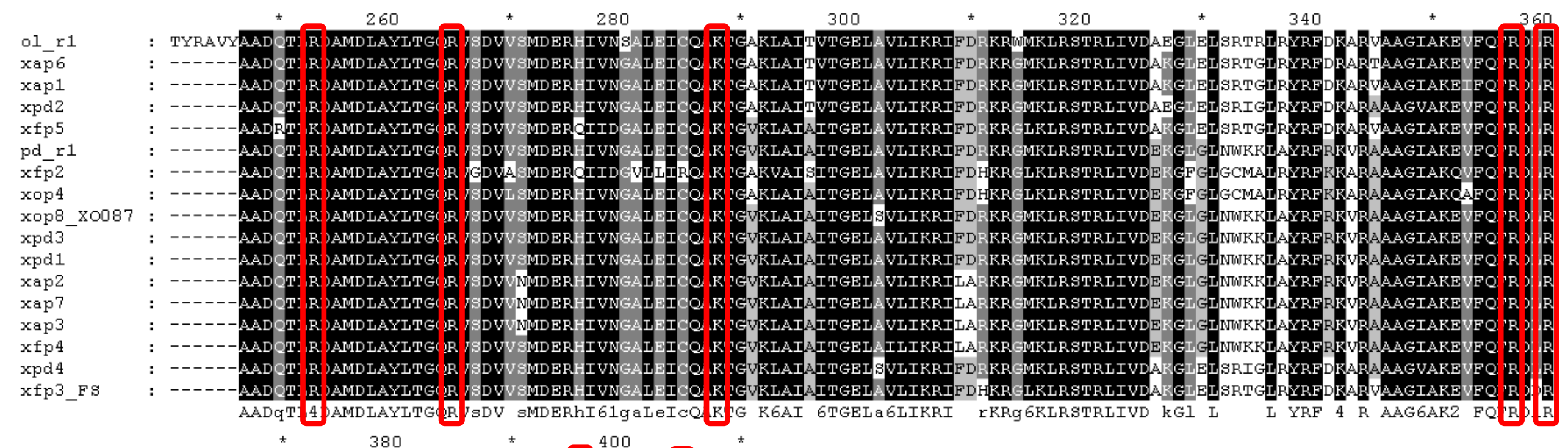

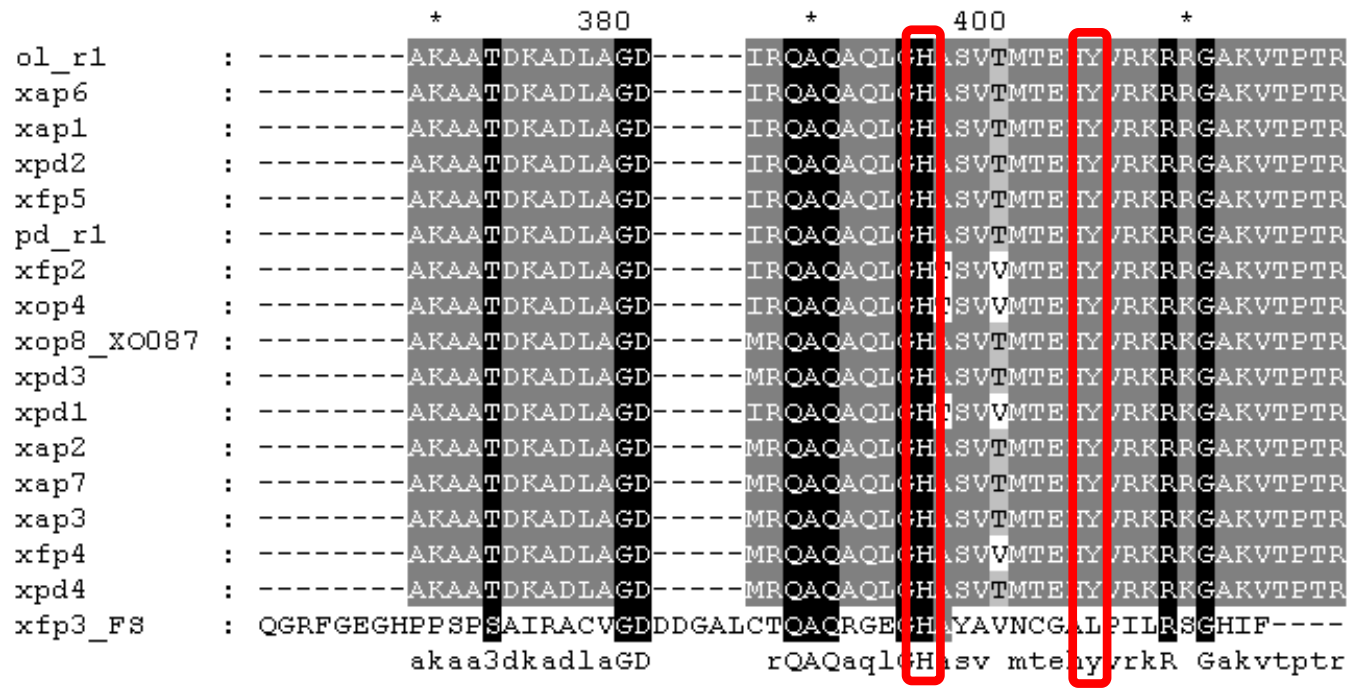


Figura II.C. Alinhamento das integrases classificadas como ramo B. Os aminoácidos preditos como pertencentes aos sítios catalíticos conservados com as demais proteínas da família das tirosinas recombinases são destacados pelas caixas vermelhas. Os sítios catalíticos estão de acordo com a classificação do banco CDD.
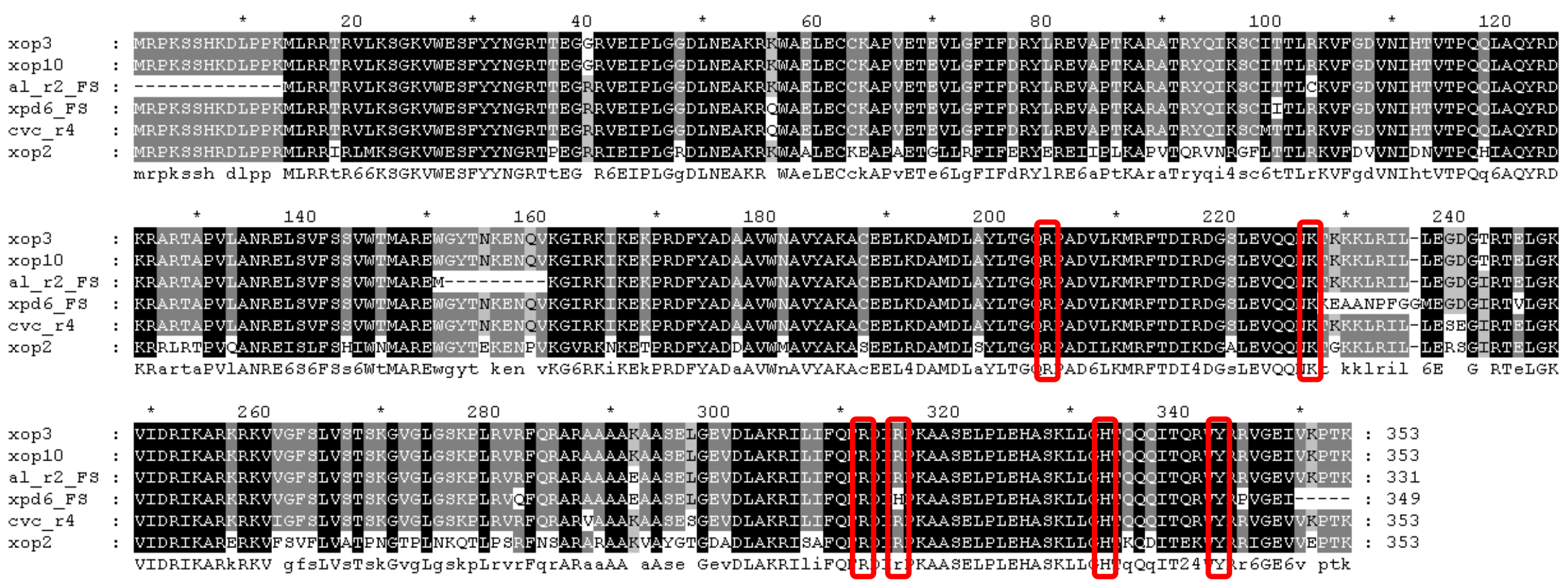
Figura II.D. Alinhamento das integrases classificadas como ramo C. Os aminoácidos preditos como pertencentes aos sítios catalíticos conservados com as demais proteínas da família das tirosinas recombinases são destacados pelas caixas vermelhas. Os sítios catalíticos estão de acordo com a classificação do banco CDD.

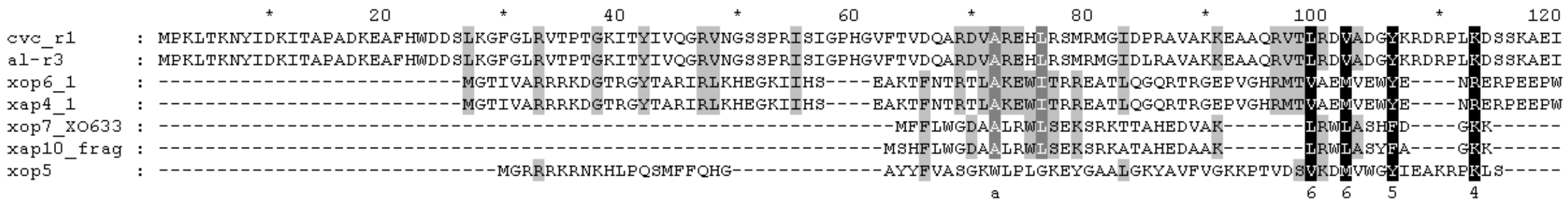

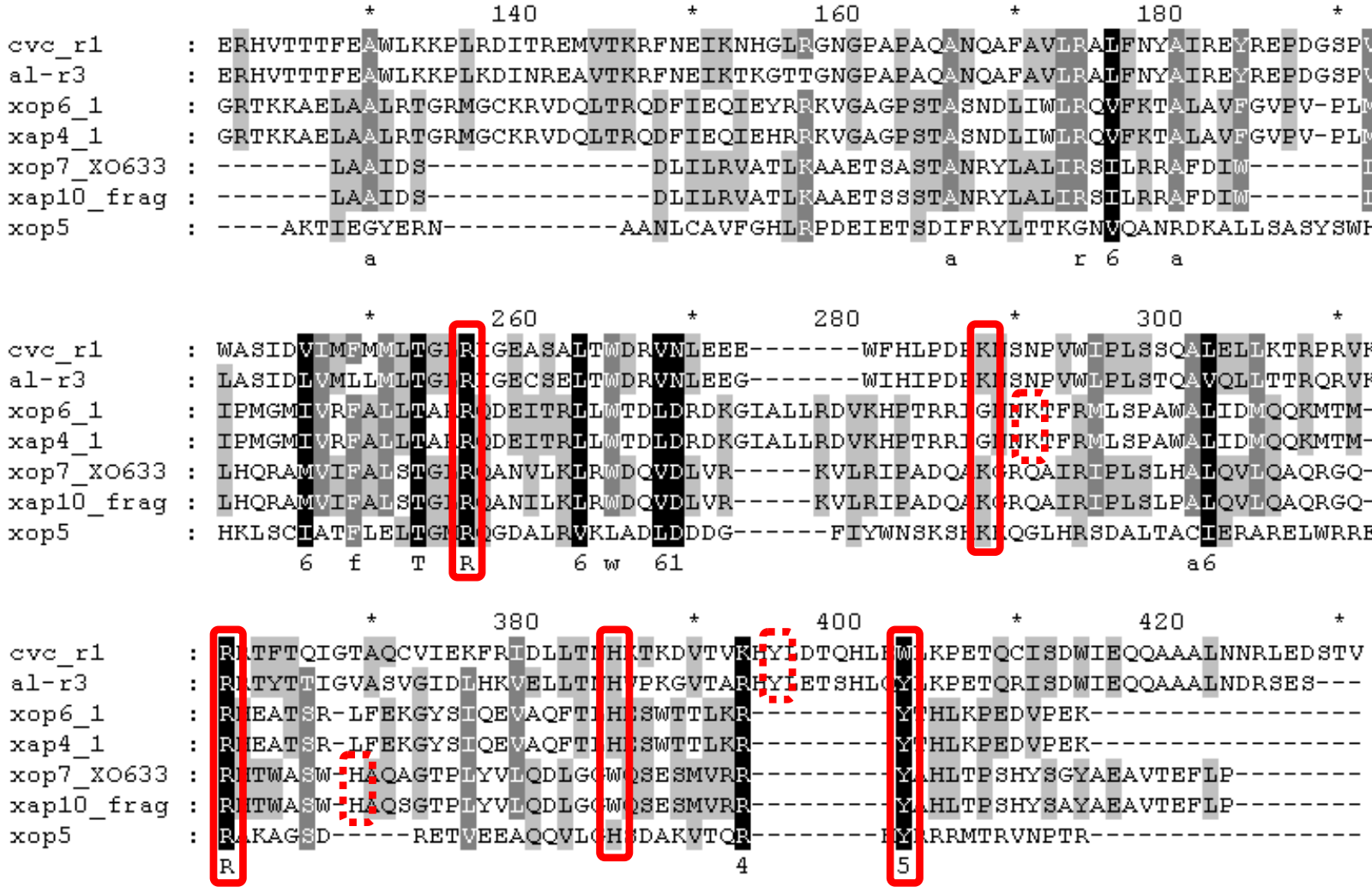


Figura II.E. Alinhamento das integrases classificadas como ramo D. Os aminoácidos preditos como pertencentes aos sítios catalíticos conservados com as demais proteínas da família das tirosinas recombinases são destacados pelas caixas vermelhas. Os sítios catalíticos estão de acordo com a classificação do banco CDD.

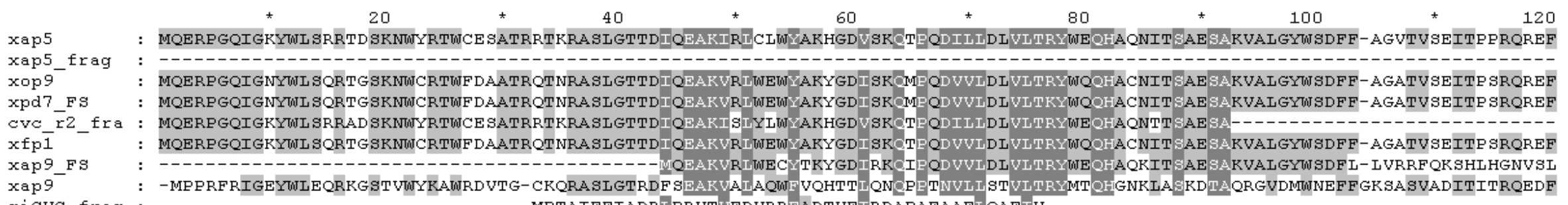

xap 9

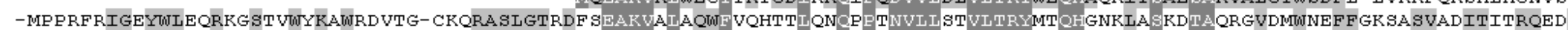
giCvC_frag : eak 1

q p l v t y qh $\mathrm{s}$ a

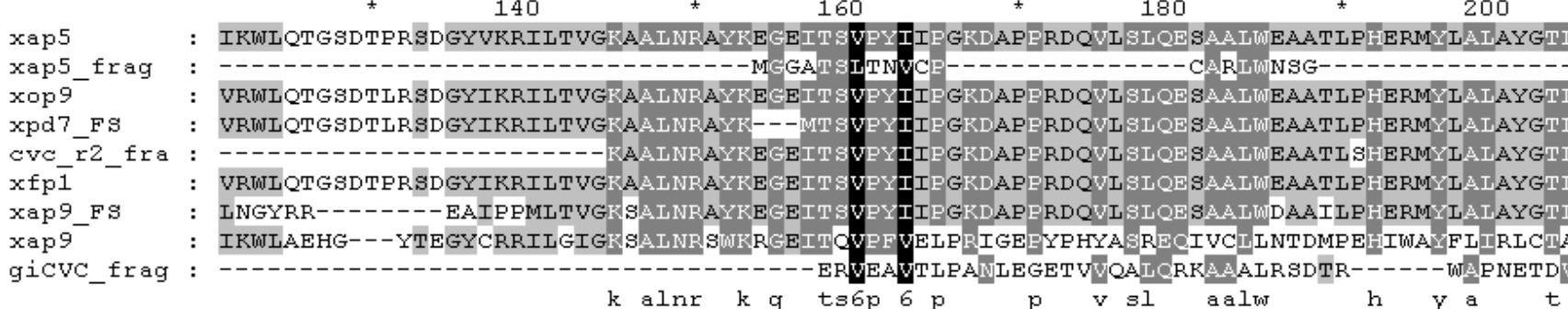

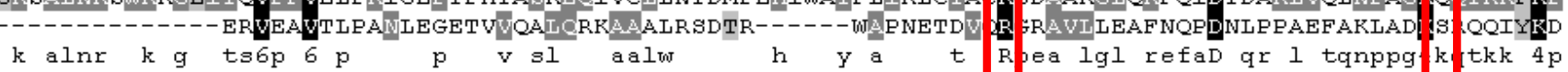

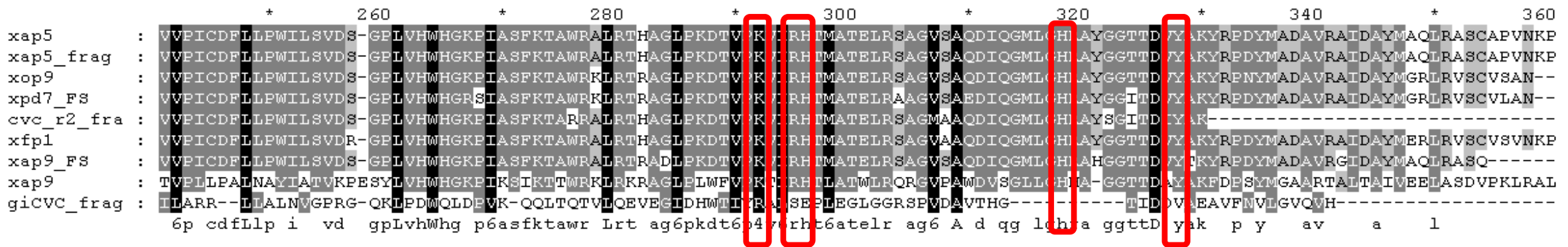

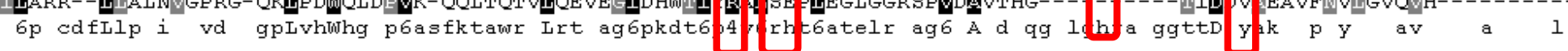

$$
\text { * } 380
$$

400

xap5 : QIMQPIDFIGGRCRVRTCDPCRVRVDEN------------

xap5_frag : QIMQPIDFIGGRCRVRTCDPCRVKAMLYR-----------

$\mathrm{xop} 9$

xpd7_Fs

cve $\overline{\mathrm{r}} 2$

xap9 $F$

xap9 ${ }^{-}$

----------KIEDCATY

gicve_frag : --.-----

QIAQPIDFIGGRCRVRTCDFCRVKAMLYR-----------

LGVNLGSVISFSSASETKKTYNNOYVKLVGGTGFEPVAPTMSR 
Figura II.F. Alinhamento das integrases classificadas como ramo E. Os aminoácidos preditos como pertencentes aos sítios catalíticos conservados com as demais proteínas da família das tirosinas- recombinases são destacados pelas caixas vermelhas. Os sítios catalíticos estão de acordo com a classificação do banco CDD.
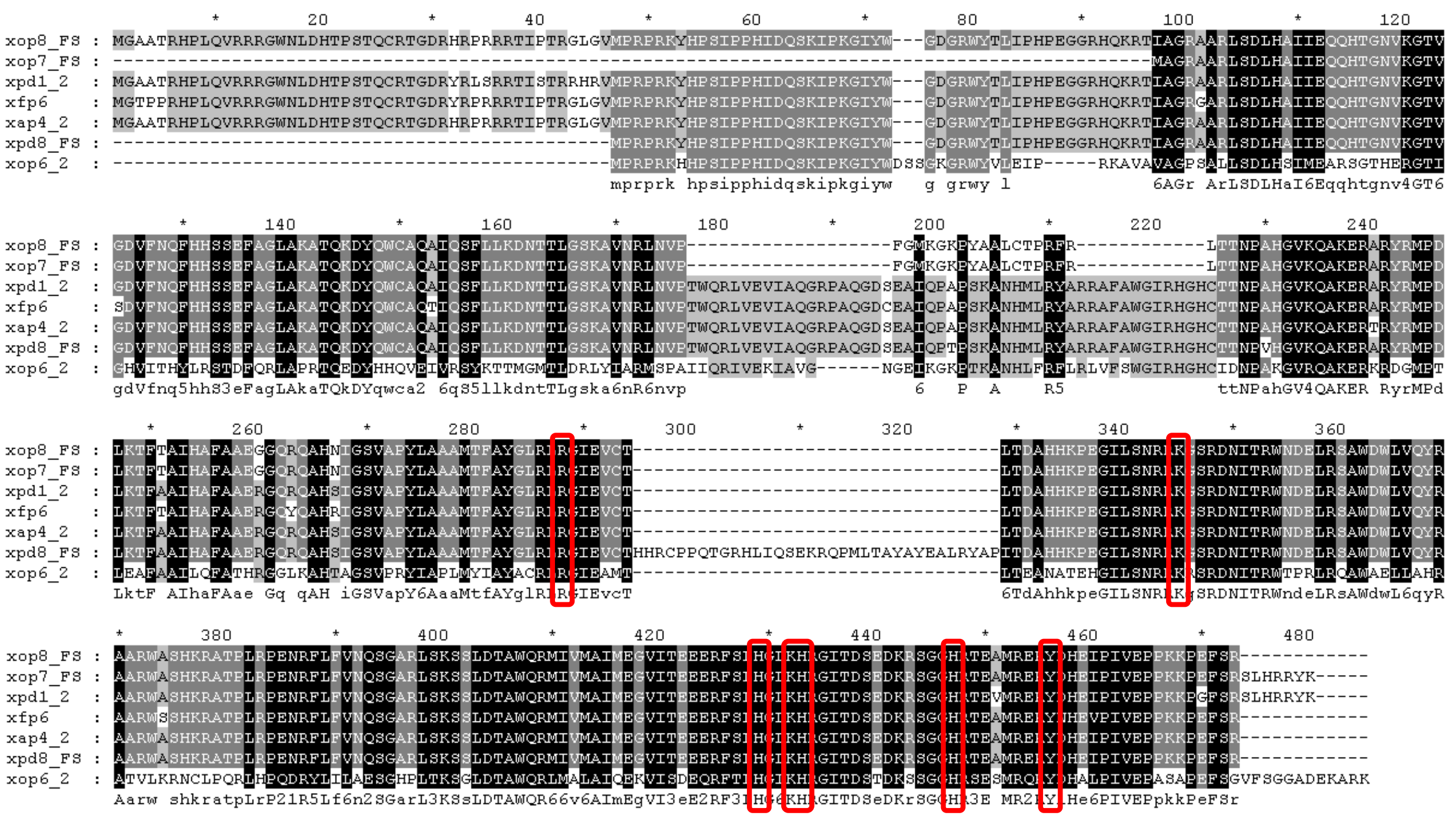


\section{ANEXO III - DOMÍNIOS DAS INTEGRASES}

Tabela III.A: Domínios presentes nas integrases de $\underline{\mathbf{X f}-\mathbf{A l}}$, identificados no InterPro e CDD. A representação esquemática foi feita com base no tamanho da proteína e posição dos domínios (100 aa $=2 \mathrm{~cm}$ ). A lista e descrição de cada domínio estão apresentados no item Materiais e Métodos. Para efeito de simplificação o domínio IPR011010 não encontra-se representado nas figuras, uma vez que ele aparece sempre associado aos outros dois domínios InterPro, IPR002104 e IPR13762.

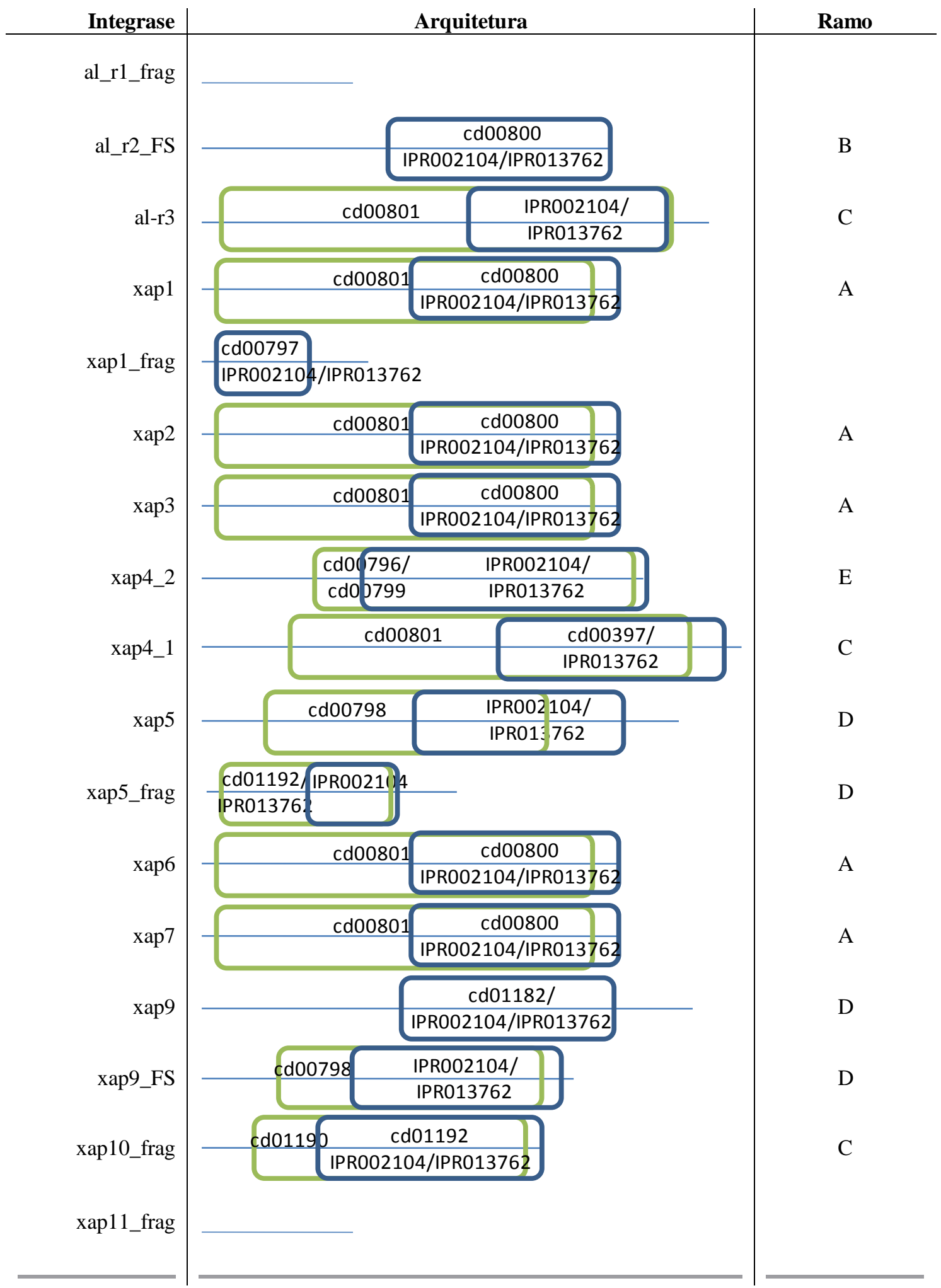




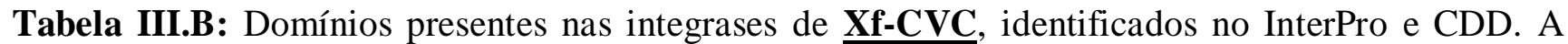
representação esquemática foi feita com base no tamanho da proteína e posição dos domínios (100 aa $=2 \mathrm{~cm}$ ). A lista e descrição de cada domínio estão apresentados no item Materiais e Métodos. Para efeito de simplificação o domínio IPR011010 não encontra-se representado nas figuras, uma vez que ele aparece sempre associado aos outros dois domínios InterPro, IPR002104 e IPR13762.

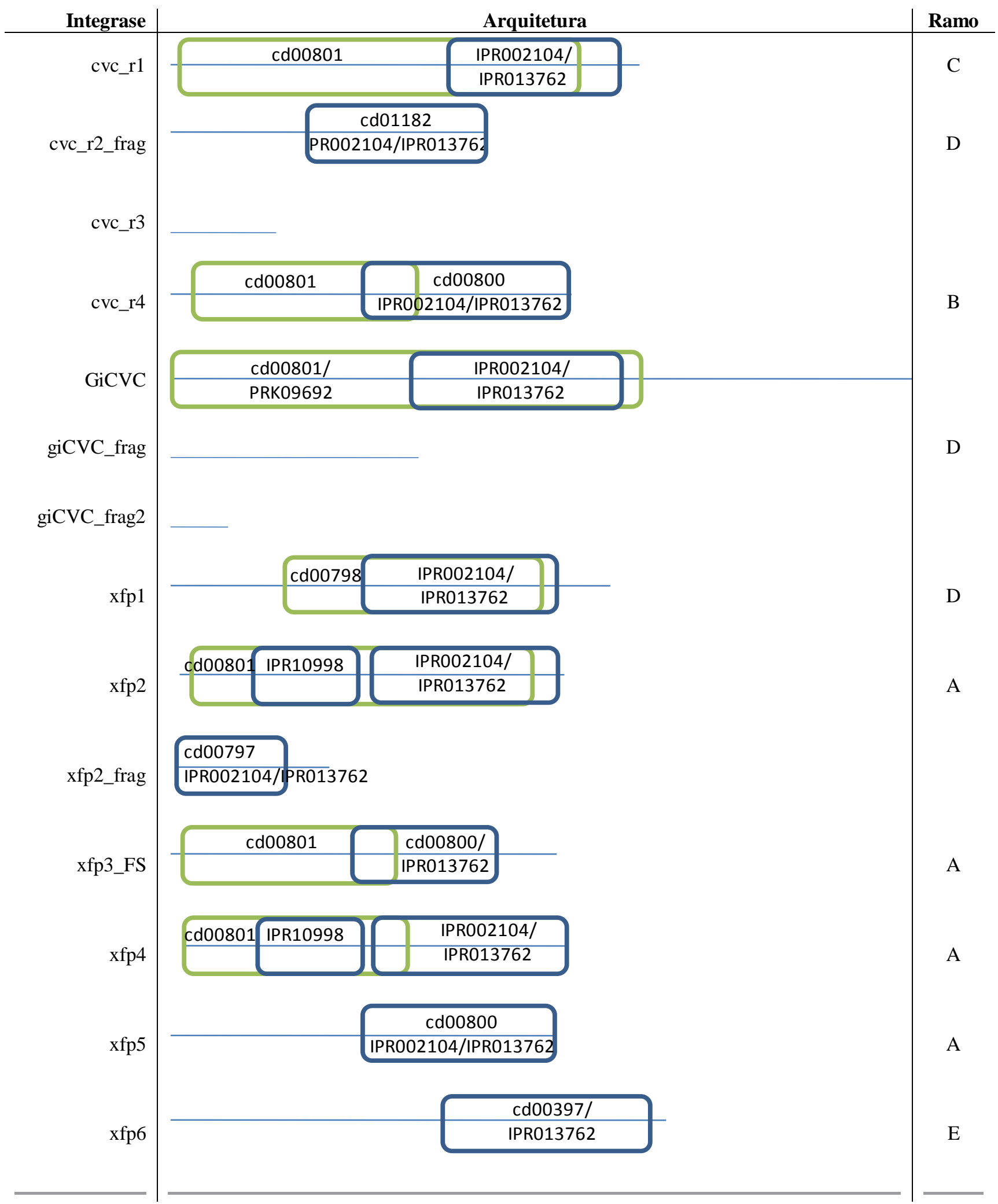




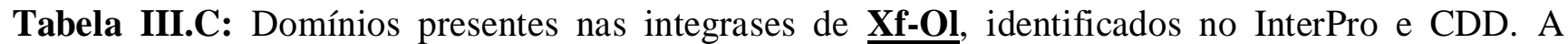
representação esquemática foi feita com base no tamanho da proteína e posição dos domínios (100 aa $=2 \mathrm{~cm}$ ). A lista e descrição de cada domínio estão apresentados no item Materiais e Métodos. Para efeito de simplificação o domínio IPR011010 não encontra-se representado nas figuras, uma vez que ele aparece sempre associado aos outros dois domínios InterPro, IPR002104 e IPR 13762.

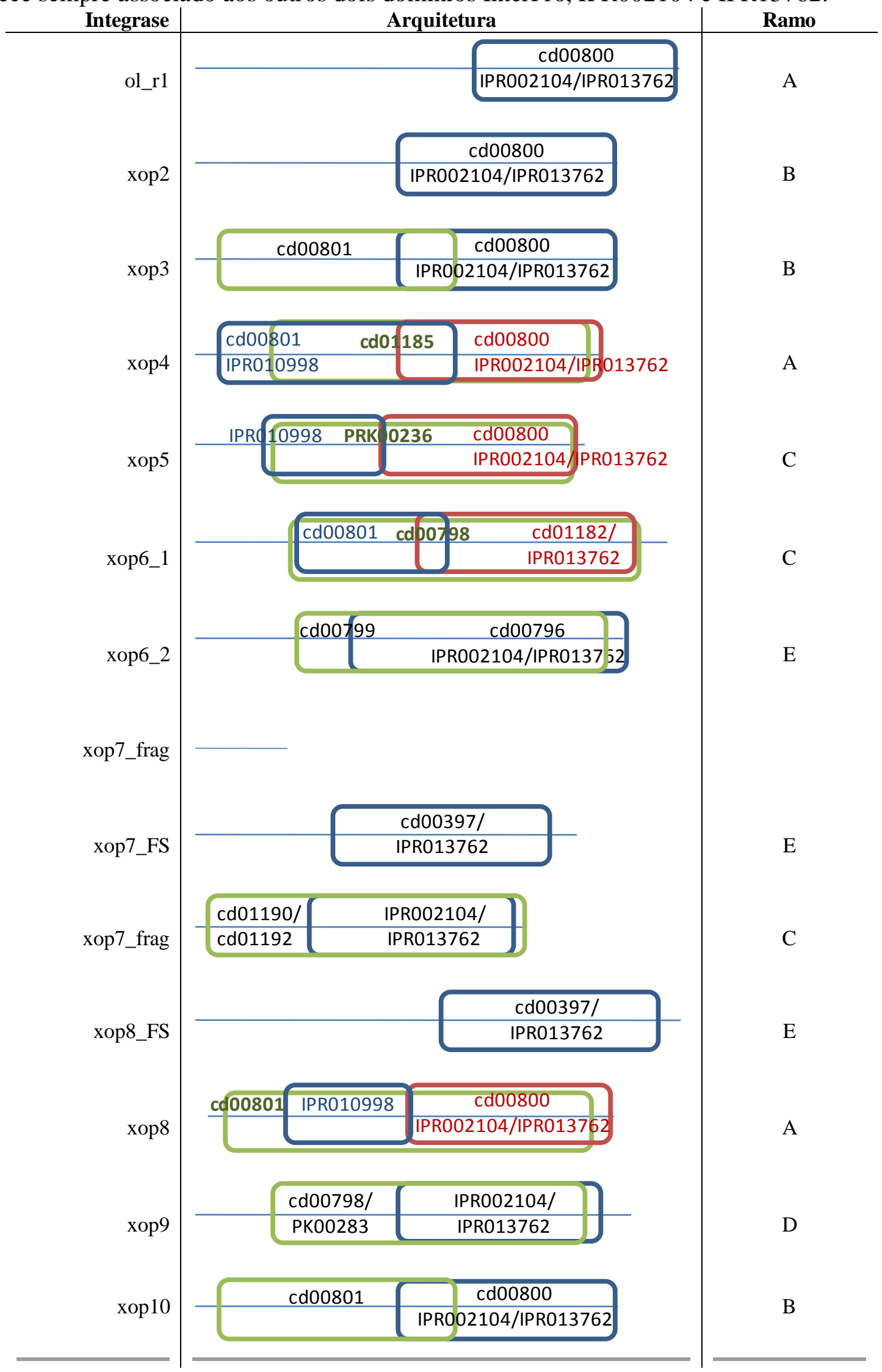

Tabela III.D: Domínios presentes nas integrases de $\underline{\mathbf{X f}-P D}$, identificados no InterPro e CDD. A representação esquemática foi feita com base no tamanho da proteína e posição dos domínios (100 aa 
$=2 \mathrm{~cm}$ ). A lista e descrição de cada domínio estão apresentados no item Materiais e Métodos. Para efeito de simplificação o domínio IPR011010 não encontra-se representado nas figuras, uma vez que ele aparece sempre associado aos outros dois domínios InterPro, IPR002104 e IPR13762.

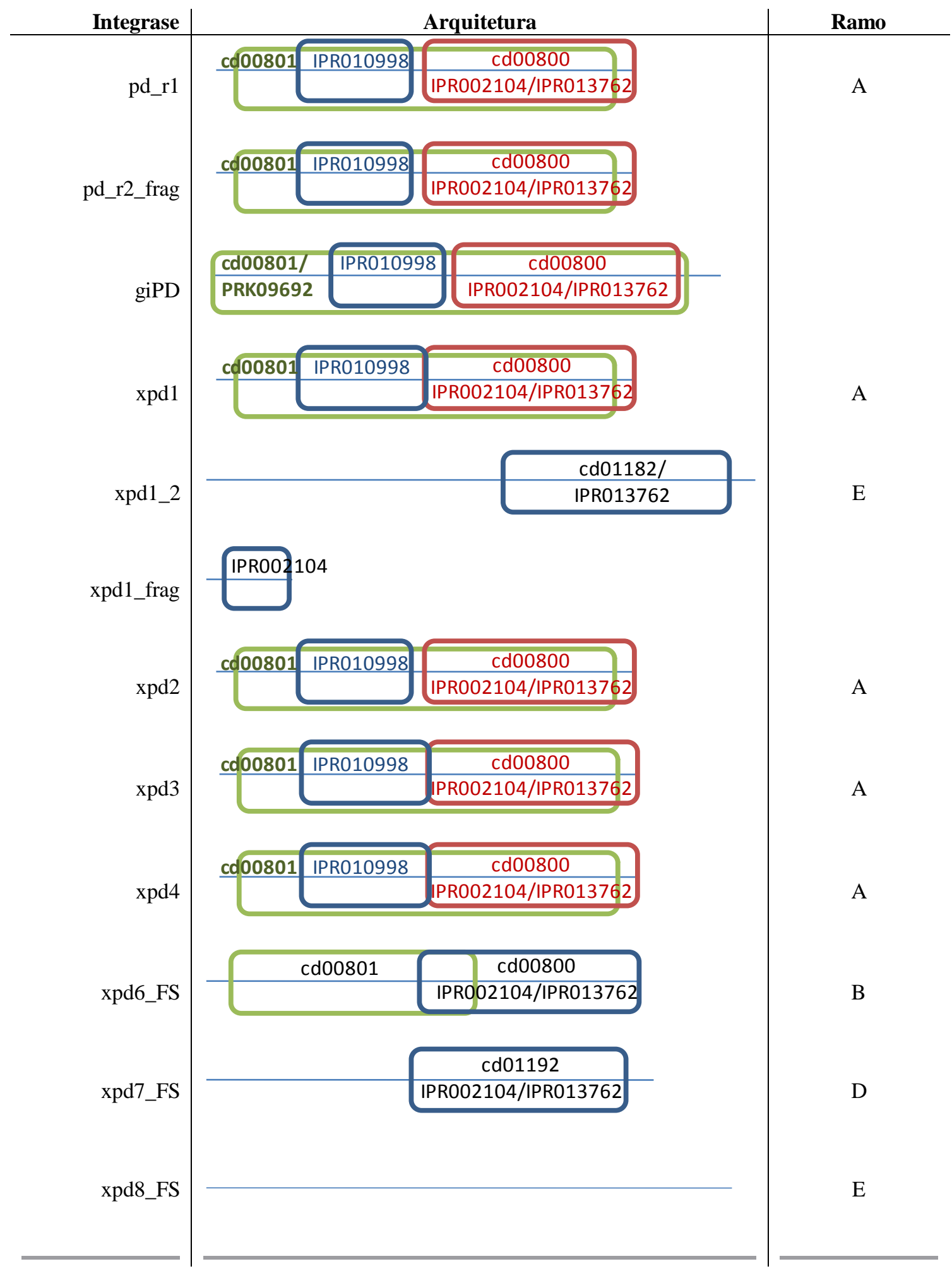


ANEXO IV - MAPAS GENÔMICOS (http://gracilaria.ib.usp.br/integraseDB)

Legenda. Mapa genômico das quatro linhagens, informando posição das regiões de profagos, tRNAs e integrases. As regiões de profagos que apresentam similaridade de sequência e compartilham mesmo contexo genômico em linhagens diferentes estão representadas nas cores: azul (cvc-r4, xpd6, xop10 e AL-r2), verde (xpd5 e xap7), amarelo (xpd3 e xop1), vermelho (cvc-r1 e al-r3) e azul claro (xap2, ol-r1 e pd-r1); e para as regiões de profagos que compartilham similaridade de sequências, representadas nas cores: marrom (xfp1, xfp2, xpd1, xop3, xap1 e xap5), laranja (xfp3, xfp4, xpd2, xop9, xap3, xap7 e xap9) e rosa (xfp6, xop6 e xap8). As demais regiões relacionadas a profagos estão representadas em cinza. As integrases estão indicadas por caixas de texto contendo a letra referente ao ramo de classificação para cada integrase (Tópico 4.2, figura 4.3). 


\title{
ANEXO V - MANUSCRITO: Xylella fastidiosa prophage-like regions study reveals their origin, dynamics and their association to genome differentiation
}

\author{
Alessandro de Mello Varani ${ }^{1}$, , Rangel Celso Souza ${ }^{2}$, Helder I Nakaya ${ }^{3}$ Wanessa Cristina de Lima ${ }^{1}$, Luiz Gonzaga Paula de Almeida ${ }^{2}$, Elliot Watanabe Kitajima ${ }^{4}$, Jianchi \\ Chen ${ }^{5}$, Edwin Civerolo ${ }^{5}$, Ana Tereza Ribeiro Vasconcelos ${ }^{2}$, and Marie-Anne Van Sluys ${ }^{1 *}$
}

\begin{abstract}
${ }^{1}$ Genome and Transposable Elements Laboratory (GaTE Lab), Departamento de Botânica, Instituto de Biociências, Universidade de São Paulo; 05508-090 - São Paulo/SP, BRAZIL ${ }^{3}$ Departamento de Bioquímica, Instituto de Química, Universidade de São Paulo, 05508-900 São Paulo, SP, BRAZIL ${ }^{2}$ Laboratório de Bioinformática (LABINFO), Laboratório Nacional de Computação Científica, Petrópolis/ RJ, BRAZIL ${ }^{4}$ Escola Superior de Agricultura Luiz de Queiroz. (ESALQ), Universidade de São Paulo, São Paulo/SP, BRAZIL ${ }^{5}$ United States Department of Agriculture, Agricultural Research Service, San Joaquin Valley Agricultural Sciences Center, 9611 South Riverbend Avenue, Parlier, CA 93648, USA
\end{abstract}

Keywords: Xylella fastidiosa, Comparative Genomics, Prophage, evolutionary lineages, Integrases, , microarray analys is.

\section{ABSTRACT}

Prophage-like elements and possibly phage remnants constitute major drivers of the Xylella fastidiosa genome differentiation, accounting for nine to $15 \%$ of the genome composition. To better evaluate the recent evolution of the $X$. fastidios $a$ chromosome backbone among distinct pathovars, the number and location of prophage-like regions were assessed on two finished genomes (9a5c and Temecula1), and in two candidate molecules (Ann1 and Dixon). Based on comparative $\mathrm{BBH}$ analyses, the majority $(51 \%)$ of the predicted genes in the $X$. fastidiosa prophage-like regions are related to structural phage genes belonging to the Siphoviridae family. Electron micrograph reveals the existence of putative viral particles in the bacterium cell in planta with similar morphology to lambda phages. Moreover, analysis of microarray data deposited in GEO database indicates that $9 \mathrm{a} 5 \mathrm{c}$ strain cultivated under stress conditions presents enhanced expression of phage anti-repressor genes, suggesting switches from lysogenic to lytic cycle of phages under stress-induced situations. Finally, clustering analyses of phage integrase genes based on multiple alignment patterns reveal they group in five lineages, all possessing a tyrosine recombinase catalytic domain. Integration sites and tRNA association is also evidenced. In summary, we present comparative and experimental evidences suggesting the influence and contribution of phage activity on the differentiation of Xylella genomes.

\section{INTRODUCTION}

$X$. fastidiosa is a gram-negative gamma-proteobacterium known to cause several economically important diseases in cultivated crops and many other plant species. The strain 9a5c (Xf-CVC) was the first plant pathogen whose genome was completely sequenced (42). This was followed by the publication of draft sequences from the gappedgenomes of strains Dixon (Xf-ALS) and Ann1 (Xf-OLS) (9) and the complete genome of the PD-associated Temecula-1 strain (48). Genomic analysis in different Xylella strains reveal interesting biological and evolutionary aspects regarding genome structure and gene content. Previous studies demonstrated that $98 \%$ of the Xf-PD genes are shared with $\mathrm{Xf}-\mathrm{CVC}$, with an average amino acid identity (considering only the coding regions) of $95.7 \%$, and the main differences are from bacteriophage-derived regions. These bacteriophage-derived regions are responsible for chromosomal rearrangements and deletions in $X$. fastidiosa strains, thus playing a decisive role on the genome evolution of this plant pathogen $(42,48)$.

Recently published work demonstrate that virus particles, including bacteriophages, appear to be strikingly abundant, with a typical estimated concentration of $10^{7}$ particles $/ \mathrm{ml}$ in coastal sea water and even higher in some other habitats, such as freshwater ponds (50). Based on these data, it is proposed that these particles represent the most abundant biological form on Earth (27) and potentially an efficient vehicle for lateral gene transfer. A large body of sequence data is generated by projects of bacteriophage genome sequencing, and almost 500 phage genomes have been determined and deposited in Genbank, and together with metagenomics studies (mainly from environmental samples), indicate a broad genetic diversity, representing the largest reservoir of sequence information in the biosphere $(13,39)$. Moreover completely sequenced phage genomes have a high degree of mosaicism probably derived from extensive horizontal genetic exchange occurring over perhaps as many as 3 billion years $(7,25,26)$. Furthermore, the bacteriophages have a central role in the evolution of their bacterial hosts and the emergence of new pathogens, by moving genes from host to host in a mechanism that generate gene and genome diversity, thus constituting, in many bacterial species, a substantial part of acquired DNA $(27,38)$. In some instances, lysogenic conversion of phages are of selective advantage to the bacterial host, as they can dramatically change the host phenotype (17).

To accomplish integration, temperate bacteriophages encode a phage integrase enzyme that mediates recombination between short sequences of phage DNA, the phage attachment site attP, and a short sequence of bacterial DNA, the bacterial attachment site attB. Phage integrases all fall into a category of enzymes known as site-specific recombinases (21). Each phage integrase recognizes distinct attB sequences and are grouped into two major families, based on their mode of catalysis: the tyrosine and the serine recombinases (22). At least $75 \%$ of the phage tyrosine recombinases use tRNA sequences as attachment sites in bacteria, indicating that tRNAs are directly involved in the phage acquisition process (49).

In this work, the genomes of four $X$. fastidiosa strains of, Xf-CVC, Xf-PD, Xf-OLS, and Xf-ALS, were compared with regard to their prophage content and respective predicted integrase genes. A total of 56 predicted integrases were identified, and network analysis and phylogenetic reconstructions support the existence of five major lineages related to known bacteriophages that infect gamma and betaproteobacteria. By Bidirectional Best Hit $(\mathrm{BBH})$ analysis (against 402 bacteriophage genomes), the integrases were all found to be associated mainly to phages containing structural genes of Caudovirales viruses. In silico gene expression analysis of $\mathrm{Xf}$-CVC prophage-like regions reveals these prophages are probably actively transcribed, and this finding is supported by the presence of putative phage-like particles in Xylella cells both in planta (almond petiole and hibiscus leaves) and in vitro (Chen et al., ref). Comparative studies conducted on the structure of the prophage regions and their relative genomic positions strengthen their impact in the genome organization and differentiation of these closely related $X$. fastidiosa strains.

\section{MATERIALS AND METHODS}

\subsection{Identification of Phage-related Integrases}

Potential ORFs with gene products assigned as integrases were identified by keyword and protein domain searches with BLAST program (3), against the CDD database, and aligned with CLUSTALX 2.0 (32) to further assign the positions of catalytic residues. Phylogenetic trees were constructed using Neighbor Joining (NJ) algorithm (41) and bootstrap assessment (500 replicates) as implemented in PHYLIP package (19). Trees were edited with MEGA4 program (Molecular Evolutionary Genetics Analysis) (43). 
Two-dimensional distance-constrained, spring-embedded and cluster-based phage-integrase network layouts were constructed with InterView program (28), with the phage integrases interactions determined by an all-against-all BLASTP program with an e-value of $10^{-5}$

\subsection{Identification of Prophage-like Regions}

All previously described prophages in the $\mathrm{Xf}-\mathrm{CVC}$ and $\mathrm{Xf}-\mathrm{PD}$ genomes $(42,48)$ were used as a reference to the identification of potential prophage regions in ALS and OLS by similarity search. The ALS and OLS candidate prophage-like regions were computed and automatically annotated with BlastX searches (3). The resultant annotation was searched by using specific keywords (e.g. phage, integrase, tail, capside, terminase, portal, head, neck, fiber), and for the positive matches a neighbor analysis was performed in order to fin more phage-like genes. A minimum size of $10,000 \mathrm{bp}$ was required to elect any potential prophage region. Smaller regions were individually analyzed and compared to the other genomes' relative positions to define them as prophage remnant regions $(\mathrm{rm})$. The same procedure was used to identify new potential prophage-like regions as well as remnant regions in the Xf-CVC and Xf-PD genomes.

\subsection{Functional Annotation of Prophage-like Regions}

Functional annotation of ORFs within potential phage regions was carried out by using the SABIA package (2) with identification of phage landmarks such a tRNA vicinity insertion. For putative functional attribution, BLAST searches (3) and COG (44), INTERPRO (4), PRINTS (6), PSORT (35) and SWISSPROT (10) databases were used.

\subsection{Clustering of prophage-like ORFs ( $X$. fastidiosa Phage Navigator Comparative Database)}

SABIA Comparative software (1) was employed to identify the common clusters of ORFs of prophage regions. This tool was adapted to perform comparative analysis amongst all $X$. fastidiosa prophage-like elements and 402 phage genomes deposited in GenBank (http://www.ncbi.nlm.nih.gov/genomes/static/phg.html) (by august 2007). All the comparative analyses were based on the Bidirectional Best Hit (BBH) methodology (37) with the following parameters: $60 \%$ of query coverage and e-value of $10^{-5}$. Comparisons between the prophage-like full-length elements were carried out with the M-GCAT program (46) and the EMBOSS package (40) both with default values. Comparisons between upstream and downstream regions of each ORF were performed with CLUSTALW 2.0 and custom PERL-scripts (http://www.perl.com), by the methodology proposed by Souza R.C (unpublished data).

Scripts in PERL and PHP (http://www.php.net) were written in order to generate the prophage gene maps (originally provided by LBI Laboratory of Bioinformatics of University of Campinas, the web-based navigator to the prophage genes and the database with integrases information). Further information and all supplementary material are available on the website project: http://gracilaria.ib.usp.br/integraseDB.

\subsection{Microarray data acquisition and analysis.}

Meta-analyses of independent microarray datasets were performed in order to study the gene expression pattern of prophage-like elements in CVC strain 9a5c in different heat shock conditions. Microarray data were extracted from series GSE3044, GSE4161, GSE4960, GSE6619 and GSE8493 $(15,16,30,31)$ on NCBI's Gene Expression Omnibus (GEO) database (http://www.ncbi.nlm.nih.gov/geo) site (18). All data processing information is available in the supplementary materials. Briefly, we established the detection limit for each slide and each dye as the mean plus 3-5 times the standard deviations of negative control spots. Cy5- and Cy3-derived intensity data from the direct comparisons between the test sample and reference sample were corrected for intensity-dependent dye biases using a Lowess function implemented in the R package (The R Project for Statistical Computing [http://www.rproject.org]). Differentially expressed transcripts or differentially gene contents were identified by using the Significance Analysis of Microarray (SAM) method (47) with a false discovery rate (FDR) $<2$ $5 \%$. The data from GSE4161 was obtained direct from the original paper (31) supplementary materials (http://blasto.iq.usp.br/ tkoide/ Xylella/Heat_shock).

\section{RESULTS AND DISCUSSION}

3.1 Prophage-like elements: organization, diversity and comparative analysis

\section{Identification of prophage-like regions}

Identification and definition of prophage-like elements is not trivial task, but an empirical approach that needs a lot of insight (12), and the knowledge of the constitution of the host core genome. In the previously reported ALS and OLS assemblies (9), prophage-like elements were not identified, and the candidate molecules were not determined for each strain. Using a new assembly methodology, specific for phage-related regions, a candidate molecule was determined for each strain, thus making possible the identification of prophage-like elements and phage remnants (data not shown or data available at lncc xylella?). In the same way, identification of all predicted integrase genes and prophage-like regions were carried in Xf-CVC 9a5c strain and Xf-PD Temecula strain genomes.

All four X.fastidiosa genomes were scanned searching for the presence of predicted integrases associated to cluster of genes related to phages. Regions encompassing more than 10,000 bases were defined as prohage-like regions and smaller as prophage remnants. This strategy enabled the identification of 47 chromosome fragments in X.fastidiosa genomes predicted to descent from ancestral invading bacteriophages (Table 01). The sum of all elected regions represents $1300341 \mathrm{bp}$ of the $X$. fastidiosa chromosomal backbone irrespective of the strain is of bacteriophage origin. The CVC strain contains six prophage-like regions and five phage remnant regions. In the previously published work a conservative approach was utilized and defined four prophage-like regions named xfp1-xfp4 (42). The PD strain contains eight prophagelike regions and two small phage remnant regions already reported by (48). The OLS strain candidate molecule contains ten prophage-like regions and only one phage remnant region. Finally, the ALS strain candidate molecule contains eleven prophage-like regions and three phage remnants. Almost all of these regions carry integrases with a plethora of options, and by comparative analyses of the composition of the ORFs, it is possible to infer the candidates to be a probable complete or a defective prophage, for each strain (table 01). The prophage-like and phage remnant regions span $342,510 \mathrm{pb}(12.53 \%), 239,751 \mathrm{pb}(9.50$ $\%), 339,583 \mathrm{pb}(12.97 \%)$ and $378,497 \mathrm{pb}(14.39 \%)$ of CVC, PD, OLS and ALS strains, respectively. The average length is $32 \mathrm{~kb}$ for prophagelike and $7.5 \mathrm{~kb}$ for phage remnants.

Most of the prophage-like regions (60\%) are localized between the positions $900 \mathrm{~kb}$ to $1,800 \mathrm{~kb}$ of the chromosome (position 1 being the putative origin of replication, in clockwise orientation positioned at dnaA gene), some of them positioned near the putative terminus of the replication (terminus determined by GC skew analysis). This particular distribution is suggestive that these prophage elements may represent recent acquisition in the $X$. fastidios $a$ genome probably relating to the moment in the cell cycle that insertion occurs as previously demonstrated for other prokaryotic genomes (20)

In addition, the majority of the rearrangements observed among the four genomes are concentrated in this terminal region. Alignment of the two chromosomes (Xf-CVC and Xf-PD) and the two candidate molecules (Xf-ALS and Xf-OLS), starting from the putative origin of replication, reveals at least 16 chromosomal regions in the four genomes that are translocated and/or inverted. The Xf-ALS strain presents 16 disruptions in its candidate molecule compared to the other three strains, followed by Xf-CVC strain with 14, and 13 chromosomal breaks in XfOLS and Xf-PD strains, suggesting that ALS strain is the most divergent in terms of genome structure and this divergence is directly associated to the phage related insertions. The association of phage related regions with breaks in chromosomal colinearity has been previously described when comparing Xf-CVC and Xf-PD genomes (48) and is now expanded to the other X.fastidiosa sequenced strains. Xf-PD and XfOLS strains display only 7 chromosomal breaks supporting these strains as the more recently diverged strains. In all cases, rearrangements were caused by phage insertion, as each break is bordered by a prophage-like or a phage remnant region, suggesting an important role of the phages in the genome organization of X.fastidiosa genomes (Figure 1). Taken together, these results helped to strengthen the association of the prophage-like regions with the differentiation of X.fastidiosa strains chromosomes. 
Comparisons among prophage-like regions

Analysis of prophage genes sharing similarity at the nucleotide level reveals striking features, and allows us to trace a possible evolutionary history for each group of prophages-like elements. This suggests a probable timescale of the events and the possibility to hypothesize the most ancient insertions relative to the most recent ones. Firstly we report the elements inserted in the same genome context in different strains, indicating preferred sites of insertion; thus, the ones related to common events inter strains.

There is only one site of prophage insertion shared by the four strains with almost the same gene content and genome borders: xpd6, xop10, cvc-r4 and al-r2. These regions possess the same upstream genome border located near an epsP synthase, and the downstream border near a tonB-dependent receptor, except for the xop10 element, where the downstream gene is located close to a methyltransferase. The cvc-r4 and al-r2 remnant regions appear to be degenerate regions originated from a xop10-like ancestor. Region xpd6 appears to be a degenerate form of xop10, mainly by the presence of a frameshift in the xpd6 integrase, suggesting that xop10 might be the closest from the common ancestor of this group. The xpd6 and xop 10 regions share 76.1 $\%$ nucleotide identity and carry $49 \%$ of non-essential phage cargo ORFs, $45 \%$ of hypothetical ORFs and only $6 \%$ of essential phage ORFs. The gene content of these regions includes a copy of virulence-associated protein I and a hicA/hicB toxin-anti-toxin system. Neither of these regions contains structural phage genes or is a potentially defective prophage, and xpd6 and xap10 elements have a tRNA-GLY in their constitution, suggesting a mechanism of acquisition of this tRNA by transduction. Another site of insertion is shared by three different strains, and it involves the remnants pd-r1, ol-r1, and the xap2 element They are inserted between a fumarate hydratase and glucose inhibited division protein, associated with tRNA-CYS. The three regions appear to be defective prophages in process of genome decay, and pd-r1 and olr1 appear to be a degenerated version of xap2

In these two cases, the comparative analysis strongly suggests an evolutionary mechanism of negative pressure in order to delete or fully inactivate these regions of the chromosome, in accordance to previous studies in others prophage regions (Canchaya et al., 2003). There are evidences of genome decay exclusively in prophage-like and remnants regions, deletions and mutations occur in these regions especially in the remnants regions, independent of the boundaries of the genome core.

The remaining prophage regions are inserted in regions shared by only two strains, or are in unique positions in a given strain. There are seven sites of insertion shared by prophage elements from two different strains: the first is related to elements xdp3 and xop1 $(49.2 \%$ of nucleotide identity). This pair shares the same genome borders between a lipid kinase and ParA protein and appears to consist of defective prophages, with the main difference being the absence of the integrase in xop1. They do not have the complete set of non-structural genes, and the structural gene order and content resemble a phiCTX phage, that infects Pseudomonas aeruginosa (Nakayama et al., 1999), suggesting a common ancestor from the family of P2-like phages. The second site of insertion comprises elements cvc-r3 and xap11 (less than $30 \%$ of nucleotide identity), located between a cluster of tRNAs (PRO-ARGHIS-LYS) and hemagglutinin protein. Both appear to be very degenerate regions, very close to the putative origin of replication. These two cases, where the phages appear as defective or are remnants and located near to the putative origin of replication, strongly suggest that these elements may be the most ancient insertions.

The third region is related to elements xpd4 and xap7 $(49.2 \%$ of nucleotide identity), sharing the same genome borders between a cluster of ATP-binding proteins; the main difference is related to the higher number of ORFs related to the structure of the phages particle in xap7; despite this, both appear to be defective prophages. The fourth site is associated with the remnants cvc-r1 and al-r3 (73\% of nucleotide identity) and inserted between a hypothetical and an isomerase protein, both regions are related to genomic rearrangements and have only their integrases.

The fifth site is associated with elements xpd7 and xap9 (less than $30 \%$ of nucleotide identity), inserted between a transposase and an excinuclease protein. Element xpd7 appears to be a defective prophage, as it does not have structural genes, while element xap9 possesses two integrases, suggesting a truncated element.

The sixth site is associated with elements xfp6, xop6 and xpd8 (less than $35 \%$ of nucleotide identity among the three elements), inserted between a methionyl-tRNA synthetase and a PilE protein. Elements xfp6 and xop6 share at least $68 \%$ of identity, and both have similarity of $70 \%$ with xap8 element, located in different genome context, supporting the evidence of different events of insertion. Only xfp6 appears to be an active prophage with all nonstructural and structural genes. The xpd8 seems a degenerate version and xop6 appears to be a truncated element. Finally the seventh site is associated to xop7 and the remnant cvc-r5 (less than $35 \%$ of nucleotide identity), and they are inserted between the panK-III and phosphoglycerate mutase proteins. As with the xap9 region, element xop7 has two integrases and appears to be truncated, while cvc-r5 does not have integrase.

If we do not consider the genome context (i.e. the elements neighbored by the same genes), several of the prophage elements in the four strains share high level of sequence similarity. As an example, seven prophage-like elements, xfp1, xfp2, xpd1, xop3, xap1, xap5 and xap6 are involved in large genome rearrangements and share at least $80 \%$ of nucleotide identity, and appear to be complete phages. The gene order and orientation is highly conserved among all the seven elements, the integrases being followed by non-structural (DNA helicase, DNA polymerase, phage repressor and anti-repressor, phage primase) and structural genes with both classes separated by an endolysin gene. It is interesting to note that the DNA-packaging and head genes resemble in organization and sequence the lambda-like phages, and the baseplate, tail, and tail fibers genes (gpV, gpW, gpJ, gpI, gpU, gpX and gpD) resemble the $\mathrm{P} 2$-like phages, suggesting a hybrid phage (as previously observed for xfp1 and $\mathrm{xfp} 2$ by (12)), split in two by the presence of a system of toxin and anti-toxin genes in xfp1, xpd1, xop3, xap1, xap5, and xap6 (in the same position, the xfp2 element has a transcriptional regulator). The non-structural genes are composed by the integrase followed by polymerase, repressor, anti-repressor and the primase, that resemble in organization and sequence the APSE-1 phage that infects Acyrthosiphon pisum.

In other case of similarity by global alignment, the elements xfp3, xfp4, xpd2, xop9, xap3, xap7 and xap9 share at least $80 \%$ of nucleotide identity, but only in the region of structural genes. Again, the endolysin gene splits the non-structural genes from the structural ones, resembling in organization and sequence the prophage 4 that infect Listeria innocua (derivated from the phage Sfi11), and the phage АаФ23 from Actinobacillus actinomycetemcomitans, generally associated to human oral infections (Resch et al., 2004). Differently from the prophage group discussed above, these elements are apparently under negative selection in a process of genome decay, as they do not possess all the nonstructural genes related to the DNA replication. It is important to note that $\mathrm{xpd} 2$ carries the exclusive genomic island giPD between a phagerelated protein and a phage-related terminase large subunit, causing the disruption between the non-structural and structural set genes of this element.

The fact that these elements are inserted at different positions over the four strains, and share sequence similarity in a large extension, points to recent and independent acquisitions, carried out by similar phages; however, a more parsimonious scenario, given the high levels of similarity, suggests a common acquisition of such elements by the Xylella genome, followed by duplications (when present in multiple copies in the same genome).

Is possible that massive intra-phage-genomic rearrangements, occasioned by the interaction of different phages, where one phage provides helper function for another unrelated phage in the host cell, can mobilize the DNA of another phage, given the possibility that occur illegitimate recombination in the process of the horizontal genetic exchange, originating the hybrid constitution in these regions, as well observed in Mycobacteriaphages by Pedulla et al (2003) and in Escherichia coli, Vibrio cholerae and Staphylococcus aureus by Boyd et al (2001). In another hand, long repeats in the same chromosome can act as site of rearrangement by homologous recombination, suggesting that the duplicated prophage elements, [xfp1 e xfp2], [xfp3 e xfp4] in XfCVC, and [xap1, xap5 e xap6]; [xap3, xap7 e xap9] in Xf-ALS, are responsible by the higher number of rearrangements in these strains, when compared to Xf-PD and Xf-OLS.

Comparative Analysis of the Genome Content of the Prophage-like Regions

From a total of 1,728 prophage-like genes in the four strains, 1,388 $(80.5 \%)$ belong to 290 different BBH clusters, while $339(19.5 \%)$ are not present in any $\mathrm{BBH}$ cluster. The latter group represents strain- 
specific prophage-like genes. In this specific group, $66(19.5 \%)$ are ORFs with putative functions related to essential phage genes, and 28 $(8.25 \%)$ to non-essential phages genes (with potential to carry nonessential "cargo" genes), while the remaining 245 ORFs (72.25\%) are hypothetical or conserved hypothetical genes, representing an abundant number of ORFs that can be related to genomic differentiation.

The most interesting cases of prophage-like ORFs in BBH clusters, and potentially related to bacterial pathogenicity, are the putative phagerelated PI protein (Zonular occludens toxin- like protein) present in xop7, xap10 and xpd5 (and also occur in the unpublished genomes of X strains M12 and M13); and the virulence-associated protein E, present in xfp5, xfp6, xpd8, xop6, xap8 (present only in M23 strain). The product of these ORFs may be related to interactions between the plant and the bacteria. The phage PI protein (zot) is required for phage assembly (14) and the copies found in X. fastidiosa share 55\% identity with orthologues found in the filamentous phage phiLf of Xanthomonas campestris pv. vesicatoria and phage phiSMA9 of Stenotrophomonas maltophilia, and with less than $30 \%$ identity to the orthologues of $X$. campestris pv. campestris and RSM1 phage of Ralstonia solanacearum and $R$. pickettii genome. These organisms are necrogenic plant pathogens, except Stenotrophomonas, a human pathogen also able to colonize diverse plants, especially those from Brassicaceae group (8). The hypothesis is that zot protein was acquired by the few clinical Stenotrophomonas strains only recently after infection by a filamentous phage, which probably came after certain changes in its adsorption protein from plant-pathogens (24).

A group of toxin and anti-toxin proteins in prophage-like regions (higA/higB and relE/relB) was also found. These proteins are very common in plasmids, where they increase effective stability (29), and in bacterial chromosomes (probably by phage acquisition), where they are related to stabilization of phage genomes in the host chromosome by reduction of the effective deletion rate or, contrarily, to anti-phage functions. In this case, the phage can interfere with host transcription and translation, activating addictive systems, which would then limit phage production (33).

Furthermore, the group of specific ORFs (belonging to no BBH cluster) related to non-essential phage functions have some interesting components: (a) virulence-associated protein in xfp3 (VapB-like), exclusive for the Xf-CVC strain; (b) modification methylase $\mathrm{NspV}$ and restriction NspV enzymes in xpd8 (also found in Xf strain M23) ; (c) the restriction enzyme NgoMIV and modification methylase NgoMIV in xap4; and (d) virulence-associated protein I in xop10, (and a truncated copy in xpd6, with only $53 \%$ of the length of the original). All these ORFs may be involved in interactions between plant and bacteria (a and d), or between bacterial and phage genomes (b and c). On another hand, these ORFs do not have BBH pairs against the 402 phage genomes, suggesting they are "cargo" that not necessary for phage biology, but with exclusive roles in each Xylella strain

\section{Enrichment of Xf-CVC prophage-like ORFs in different Xylella} strains

A previous study with different Xf-CVC strains isolated from symptomatic and asymptomatic plants was carried out to verify the enrichment of strain 9a5c strain ORFs in these other strains (for further information, refers to (16) and GEO database, entry GSE8493). Briefly, four of the strains $(56 \mathrm{a}, 9.12 \mathrm{c}, 187 \mathrm{~b}$, and 36f) were obtained from CVCaffected trees, while strain CV21 was obtained from a non-symptomatic tree from the same region. Strain $\mathrm{Fb} 7$ was obtained from a plant with symptoms of a CVC-similar disease (pecosita). In this work, we reanalyzed these microarray series focusing on the prophage-like regions in order to check the diversity of the pattern of hybridization of prophage-like elements of Xf-CVC strain 9a5c in other X. fastidiosa strains. The results demonstrate an enrichment of prophage-like ORFs of $22 \%$ against $7.6 \%$ of the remaining ORFs (those outside prophage regions) (Table 2), suggesting a preferred transcriptional activity in the prophage elements. Almost all the symptomatic and non-symptomatic strains have some prophage-like regions with a high number of copies in strain 9a5c ORFs, except the pecosita strain Fb7 that shows the same patterns found in strain $9 \mathrm{a} 5 \mathrm{c}$.

High numbers of copies of the xfp5 and xfp6 elements are present in all strains, and these regions possess one copy of the virulenceassociated protein E. Although element xfp5 appears to be a defective prophage in Xf-CVC strain, the transcriptional activity observed in the other strains may suggest that this region has important roles in other strains. The xfp1 and xfp2 elements are probable complete prophages with ORF compositions resembling a hybrid lambda and T4 phage, and are present high copy numbers in strain 56a strain. This suggests that they are actively transcribed and may represent the real-time action of phages in these strains.

Low numbers of copies of the xfp4 region are present in both symptomatic and non-symptomatic strains (56a, 9.12c and CV21) and in equal copy numbers in the other strains. The principal feature of this region is the presence of three systems of toxin and anti-toxin genes. Despite the xfp4 appearing to be a defective prophage, this element apparently is not fully transcribed at least in strains 56a, 9.12c and CV21. This supports the idea that this element is under genome decay or stable in the host by a selective negative pressure. These findings indicate that: (1) enrichment in the number of copies of ORFs in prophage-like regions compared to the core genome ORFs in different strains, and (2) the prophage-like regions have diverse transcriptional profiles. Thus, element xfp4 may play an important, but different, role in different Xylella strains.

\section{Prophage-like regions: patterns of expression in stress conditions}

Previous microarray analyses of Xf-CVC strain 9a5c described the expression profile under stress conditions, particularly under heat shock conditions (for further details, refer to $(15,30,31)$ and GEO database entries GSE6619, GSE4161, GSE3044 and GSE4960). These microarray series were re-analyzed with the focus on the prophage-like regions, and the main results are shown in Table 3 .

Interestingly, all Xf-CVC prophage-like regions have genes differentially expressed when the bacteria are under stress conditions, and even on the phage remnants some genes are differentially regulated. Notably, among differentially expressed phage genes tend to be upregulated genes $(66 \%)$ more frequently than those that are downregulated $(34 \%)$. Anti-repressor genes are over-expressed (5 of 6 genes), followed by genes involved in phage replication and structural genes, as well some integrases (xfp1, xfp6 and cvc-r3), while repressor genes are under-expressed. This suggests that under stress conditions the prophage-like regions are activated and may trigger induction of the lytic cycle.

It is also worth noting that genes not directly related to the phage structure, as anti-toxin and virulence-associated genes, are also induced in these situations. For example, over-expression of the virulence protein present inside the $\mathrm{xfp} 3$ element, a protein that occurs exclusively in this element and strain, indicates a role in heat-shock conditions. Accordingly, the high number of hypothetical phage-related genes that are also differentially expressed suggests some important, yet unknown, roles for this class of genes.

An extensive analyses of the $250 \mathrm{pb}$ located in the upstream and downstream regions in each prophage ORF revels that the prophage and remnant regions have an increment in the number of SNPs and INDELs, and a decrease of the identity when compared to the core genome, suggesting again that these regions have a different transcriptional profile, and have diverse type of promoters, than the core genome (figure 2).

\section{Probable origin of the prophage-like regions}

All prophage-like ORFs with putative functions related to structural phage genes (i.e., capsid, fiber, tail, scaffold, and baseplate) are grouped in BBH clusters. The phage family represented the most in these BBH pair groups of BBH is the Siphoviridae family (51\%), followed for Myoviridae (32\%) and the Podoviridae (10\%) families (7\% of the BBH pairs are from unclassified Caudoviridae phages). The most important and studied phage within the Siphoviridae family is phage lambda, widely found in the chromosome of enterobacteria, where it plays diverse biological roles, most of them related to acquisition of virulence genes by the bacteria through LGT (5). In a extensive review of morphology of phage particles carried out by Ackermann (2007) the closest-related Xanthomonas genus have at least 35 types of tailed phages, where $25(72 \%), 9(25 \%)$ and $1(3 \%)$ and are from Siphoviridae, Myoviridae and Podoviridae families respectively.

Moreover, there is also electron micrograph evidence for the existence of viral particles with lambda phage-like morphology within bacterial cells in planta (Figure 3). This suggests the possibility of a common Xf phage ancestor from the lambda phage family. The data suggests that the prophage-like elements present in Xylella genomes 
represent not only an ancient and stalled event that occurred in the genome before the differentiation of the strains, but a dynamic and realtime event by temperate phages dramatically shapes the genome. Putative Xf phages could carry specialized components that may confer a level of specialization or advantage to their host, in a similar manner as in E. coli, Streptococcus pyogenes and Staphylococcus aureus $(11,36$, 45).

\subsection{Integrases: diversity, domains and site of integration associated with tRNAs.}

\section{Identification, clusterization and domains of prophage-related integrases}

Integrases are useful markers for identifying prophages and potential points of LGT events in bacterial genomes (12). These are also required to either establish or exit from the lysogenic state. All the integrases identified in the Xylella genomes are from the family of tyrosine recombinases, with the potential catalytic signature identified (proposed by (22)), and possess protein domains related to the breaking and rejoining of single strands in pairs to form a Holliday junction intermediate. Almost all prophage-like regions in the four Xf strains bear one or two putative integrase genes. It was not possible to identify an integrase-like gene in only 4 of 46 regions (Table 1). The integrases in X. fastidiosa occur in three distinct forms: (1) full-length gene; (2) ORF with a frameshift (FS) or a stop codon in the frame (SCF); or (3) small fragments (less than 150 residues). There are 33 full-length integrases with 10 in the Xf-ALS, 9 in the Xf-OLS, and 7 each in the Xf-CVC and Xf-PD strains. Most of these are associated with the largest prophage-like regions and the genomic islands (giCVC and giPD). There are 10 integrases with FS/SCF 3 each in the Xf- PD and Xf-OLS, and 2 each in the Xf-CVC and Xf-ALS strains, all associated to prophage-like regions with length less than $20 \mathrm{~kb}$. There are 13 integrase fragments, with 5 each in the Xf-CVC and Xf-ALS, 2 in the Xf-PD, and 1 in the $\mathrm{Xf}$-OLS strains. Most of these are associated with phage remnants.

There are three main relationships between the integrases and these prophage elements: (1) all the (potentially) complete and the larges prophage elements carry full-length integrases, (2) truncated integrases (with SCF/FS) are present in probable defective and smaller prophages; (3) fragments of integrases are found mainly in phage-remnants, while non-remnant regions always bear another full-length integrase when a fragment is present. These results suggest the existence of a selective negative pressure associated with the integrase inactivation with further genome decay of the most ancient prophage elements.

From the alignment with model tyrosine-recombinases, the conserved active residues $\mathrm{R}$ [212], K [225], H [308], R [311], H [333] and $\mathrm{Y}$ [342] (numbers within brackets refer to the model integrase from the lambda-phage integrase; see (22)), responsible for the catalytic activity, were identified at the C-terminal end of all full-length phage integrases. The exception is residue $\mathrm{H}$ [308], not found in the majority of the integrases. However, this residue is also absent from several other tyrosine-integrases (according to the model deposited on the CDD database). Variation in spacing and amino acid sequence was observed from class to class. Nevertheless this motif is remarkably conserved (see Supplementary Material for the alignments). Moreover, all full-length integrases possess the CDD domains related to lambda and P4 integrases.

The only exception is related to the integrases identified within the genomic islands giCVC and giPD that are present in the genomes of the Xf-CVC and Xf-PD strains, respectively (48). These integrases do not possess the same catalytic signature and similarity of amino acid residues as with the other $\mathrm{Xf}$ integrases associated with prophage-like regions. However, they have a characteristic CDD domain from phage $\mathrm{CP} 4$ integrase.

\section{Evolutionary Relationships of the Integrases}

In order to determine the evolutionary relationships among the integrases, the protein sequences were organized into clusters (except fragments with less than 100 residues) by pairwise sequence diversity, and are presented in a spring-embedded layout (Figure 4). This network analysis revealed the presence of five clusters of integrases, with one larger cluster consisting of 25 integrases, and four smaller groups with up to eight integrases for each group. This reflects the diversity of the integrases inside each genome and among the four strains analyzed, and reveals distinct evolutionary histories for each group.

To further evaluate such diversity, the integrase sequences were aligned against 132 homologues from prophage-like regions of other bacterial species (Figure 6); and against 186 integrases present inside phage particles (Figure 5). Interestingly, the two different approaches, phylogenetic analysis and network clustering, reveal the same groups of integrases, denoted in Figures 2, 3 and 4 as groups A, B, C, D and GI (discussed further below) as the atypical position of xop5 in all analyses. The xop5 integrase is different from the others as it shares only $35 \%$ and $31 \%$ protein identity with the closer related organisms, Shewanella loihica and Pseudomonas syringae pv. tomato, respectively. The main feature of xop5 prophage is the presence of a Tfp pilus assembly protein in the region related to putative structural phages genes. However, this element does not have any well-characterized structural phage gene. This suggests an ancient and defective prophage element, but exclusively in the Ann1 strain genome.

Integrase group A includes the highest number of integrases with all of them related to probable complete prophages. This integrase group is related to prophages from few beta- and gamma-proteobacteria species, such as Pseudomonas, Actinobacillus and Nitrosomonas (Figure 4), revealing a restrict phyletic pattern. The same restricted neighborhood is noted in a phylogenetic analysis with integrases from viral particles (Figure 3). That is, they are related to Siphoviridae viruses of Burkholderia (a beta-proteobacteria) and two Archaea species (Methanobacterium and Methanothermobacter).

Group B is includes eight integrases, and is related only to prophages from gamma-proteobacteria species (Escherichia, Yersinia, Marinomonas and several Xanthomonas species) This is probably a restricted group of integrases, emerging late in the evolutionary scale (Figure 4). Xanthomonas is the closest phylogenetically related group to Xylella with a reduced number of prophages. The close relationship of the integrases in both groups points to an early origin for this specific class of phage-related elements, probably dating from before the speciation of the Xanthomonadales. This group is related to three viruses infecting enterobacteria, all belonging to the lambda-like group of Siphoviridae (figure 05)

Group D comprises eight integrases (including one from a remnant phage region), and it is related phylogenetically to a broader class of prophages infecting Gram-positive and Proteobacteria species (Figure 6). Interestingly, these integrases are related only to viruses infecting Gram-positive Actinobacteria species (Mycobacterium and Streptomyces), all from Siphoviridae viruses (figure 05).

Group $\mathrm{C}$ is a heterogeneous group, and it is related to the integrases from genomic islands by network clustering (Figure 4). This heterogeneity is also revealed by the phylogenetic analysis, placing the Xylella integrases over a broad range of tree branches. Four integrases (xop7, xap10, xop6-1 and xap4-1) branched together, along with integrases of prophages infecting several species of beta- and gammaproteobacteria (Figure 6). The other two integrases, belonging to remnant regions (al-r3 and cvc-r1) branch with a wider group that includes the integrases from genomic islands (discussed below). Integrases xop7 and xap10 branch with viruses belonging to Myoviridae (mainly from P2-like group) and Podoviridae (mainly from P22-like group) viruses, while xop6-1 and xap4-1 branch elsewhere, along with GI integrases and al-r3/cvc-r1 (figure 05).

The integrases within the genomic islands of CVC and PD strains (giCVC and giPD) are related to a large group of integrases from prophages of several beta- and gamma-proteobacteria, including several Burkholderia and two Xanthomonas species (Figure 6). Moreover, they branch with other integrases from group $\mathrm{C}$ along with several Podoviridae P22-like viruses (Figure 5). It was recently reported that the integrases with the $\mathrm{CP} 4$ domain (in the related enterobacterial phage $\mathrm{P} 4$ ) potentially has cross-talk activity. It was suggested these might be used as molecular tools to modulate virulence in bacteria (34). However, there is no evidence to support the cross-talk activity of $X$. fastidiosa GI integrases.

Collectively, these results suggest a broad evolutionary history for each group of integrases identified in the Xylella genomes. They are related to several groups of prophages, infecting different groups of bacteria, including the closely related groups of beta- and gammaproteobacteria, as well distantly related groups, such as Firmicutes and Actinobacteria. There is a large diversity of putative $\mathrm{Xf}$ prophages related to Siphoviridae, Podoviridae or Myoviridae viruses. 
Integrases and the role of $t R N A$ s in integration

We also assessed the association between phage-integrases and presence of tRNAs in the vicinity of prophage regions. All phage integrases share at least 60\% identity (except xop5 integrase). Moreover, despite the high level of similarity, most of the integrases cannot share the att sites of other. These integrases may have diverse and unknown possibilities for insertion sites, but $72 \%$ of these sites are associated with tRNAs (Table 1). This agrees with previous reports wherein $75 \%$ of recombinases are thought to use tRNAs as attachment sites (23). There are eight types of tRNAs associated with integrases and prophage-like regions: Arg, Asp, Cis, Gly, Lys, Ser, Thr, Val. Insertion of t-RNA-Asn from xfp6 and t-RNA-Val from xap9 may be followed by disruption and reconstitution of the bacterial tRNA (as also reported in other genomes by (49)) (supplementary materials)

There are three types of tRNA fragments (Val, Asn, Lys) associated with prophage-elements. These fragments are probably relicts of an insertion with disruption of the ancestral tRNA without the reconstitution. With respect to tRNA-Gly, present inside prophage elements cvc-r4, xpd6, xop10 and xap3 and not directly involved as site of insertion, may be a product of phage-mediated LGT to bacteria. This is supported by comparative analysis showing that at least $81(19 \%)$ of a total of 430 phage genomes analyzed bear a tRNA in their genomes and have no direct viral function (supplementary materials). They are, in this way, possibly acquired during transduction events, and brought in to the host genome by LGT processes.

It is interesting to note that the largest (bp) prophage-like regions, and probable complete and active prophages, are associated with tRNAs with higher numbers of copies in the chromosome (Arg, Ala, Gly and Ser). This indicates that they are preferred sites of insertion and markers for genome rearrangement of recent phage acquisitions. On another hand, neither of the inherently unsuitable tRNAs described previously (Glu, Gln, His, Met, Trp) (49) were used as sites of prophage integration in Xylella

\section{CONCLUSION}

This is the first extensive study showing that the prophage-like elements have a role or function in the process of $X$. fastidiosa genome organization and differentiation. The data presented in this work clearly demonstrate the role of the phages in the diversification and speciation of $X$. fastidiosa genomes, both in a short time-scale promoting local and global rearrangements and activation/inactivation of host genes, and in a large evolutionary time-scale promoting speciation within the group by the acquisition of novel "cargo" components. This is highlighted by the diverse and common insertions for the diverse prophages elements, indicating a differential impact of common and diverse prophages in the Xylella genomes. But there is no study on the literature far now indicating that complete prophages are successfully induced and propagated in Xylella; so it is still unknown if they are functional or if they represent ancient insertions and are stalled in the bacterial chromosomes. Moreover, there is also evidence supporting that the phage activity perhaps is still in process: (1) higher levels of expression of phage-related genes, including the those related to induction of the lytic cycle under stress conditions; and (2) direct observation of putative phage-like particles associated with $\mathrm{Xf}$ cells in vitro (Chen et al., unpublished data) and in planta (Kitajima, and Chen et al., unpublished data) by transmission electron microscopy.

Besides being responsible for abrupt large-scale alterations in the structure and organization of $\mathrm{Xf}$ genomes, the prophages are also capable of carrying some "cargo" genes with function not directly related to the phage function. As most of these genes are strains specific, they may be related to specialization of the bacteria to the host, suggesting an important role in the generation of new variants of bacterial strains.

On the other hand, Xylella integrases are mostly related to lambdalike phage integrases. These phages are widely known as genetic mosaics, and some are able to perform generalized transduction that may confer drastic changes in their hosts. These findings suggest a combined model of evolution to Xylella integrases and their elements, in which site specific and illegitimate recombination take place, and the mosaic architecture of the prophage elements represent a creative process in order to generate genetic variation, driving forces to the evolution of this genera.
Taken together, these results helped to determine the role and diversity of each prophage-like region, disclosing the mechanism and integration sites of the integrases associated to these regions and their influence in the differentiation of Xylella strains genomes.

Finally the results presented here clearly indicate that the evolutionary divergence of different $\mathrm{Xf}$ strains is mediated primarily by phages, and that Xylella phages can act in a similarly as do lambda phages of E. coli. This work sheds light on the biology of Xylella prophages and proposes new avenues to evaluate their potential role in the pathosystem

\section{REFERENCES}

1. Almeida, L. G., R. Paixao, R. C. Souza, G. C. Costa, D. F. Almeida, and A. T. Vasconcelos. 2004. A new set of bioinformatics tools for genome projects. Genet Mol Res 3:26-52.

2. Almeida, L. G., R. Paixao, R. C. Souza, G. C. Costa, F. J. Barrientos, M. T. Santos, D. F. Almeida, and A. T. Vasconcelos. 2004. A System for Automated Bacterial (genome) Integrated Annotation--SABIA. Bioinformatics 20:2832-3.

3. Altschul, S. F., T. L. Madden, A. A. Schaffer, J. Zhang, Z. Zhang, W. Miller, and D. J. Lipman. 1997. Gapped BLAST and PSI-BLAST: a new generation of protein database search programs. Nucleic Acids Res 25:3389402 .

4. Apweiler, R., T. K. Attwood, A. Bairoch, A. Bateman, E. Birney, M. Biswas, P. Bucher, L. Cerutti, F. Corpet, M. D. Croning, R. Durbin, L. Falquet, W. Fleischmann, J. Gouzy, H. Hermjakob, N. Hulo, I. Jonassen, D. Kahn, A. Kanapin, Y. Kara vidopoulou, R. Lopez, B. Marx, N. J. Mulder, T. M. Oinn, M. Pagni, F. Servant, C. J. Sigrist, and E. M. Zdobnov. 2001. The InterPro database, an integrated documentation resource for protein families, domains and functional sites. Nucleic Acids Res 29:3740.

5. Asakura, M., A. Hinenoya, M. S. Alam, K. Shima, S. H. Zahid, L. Shi, N. Sugimoto, A. N. Ghosh, T. Ramamurthy, S. M. Faruque, G. B. Nair, and S. Yamasaki. 2007. An inducible lambdoid prophage encoding cytolethal distending toxin (Cdt-I) and a type III effector protein in enteropathogenic Escherichia coli. Proc Natl Acad Sci U S A 104:14483-8.

6. Attwood, T. K. 2002. The PRINTS database: a resource for identification of protein families. Brief Bioinform 3:252-63.

7. Bamford, D. H., R. M. Burnett, and D. I. Stuart. 2002. Evolution of viral structure. Theor Popul Biol 61:461-70.

8. Berg, G., P. Marten, and G. Ballin. 1996. Stenotrophomonas maltophilia in the rhizosphere of oilseed rape: occurrence, characterization and interaction with phytopathogenic fungi. Microbiol Res 151:19-27.

9. Bhattacharyya, A., S. Stilwagen, N. Ivanova, M. D'Souza, A. Bernal, A. Lykidis, V. Kapatral, I. Anderson, N. Larsen, T. Los, G. Reznik, E. Selkov, Jr., T. L. Walunas, H. Feil, W. S. Feil, A. Purcell, J. L. Lassez, T. L. Hawkins, R. Haselkorn, R. Overbeek, P. F. Predki, and N. C. Kyrpides. 2002. Whole-genome comparative analys is of three phytopathogenic Xylella fastidiosa strains. Proc Natl Acad Sci U S A 99:12403-8.

10. Boeckmann, B., A. Bairoch, R. Apweiler, M. C. Blatter, A. Estreicher, E. Gasteiger, M. J. Martin, K. Michoud, C. O'Donovan, I. Phan, S. Pilbout, and M. Schneider. 2003. The SWISS-PROT protein knowledgebase and its supplement TrEMBL in 2003. Nucleic Acids Res 31:365-70.

11. Brussow, H., C. Canchaya, and W. D. Hardt. 2004. Phages and the evolution of bacterial pathogens: from genomic rearrangements to lysogenic conversion. Microbiol Mol Biol Rev 68:560-602.

12. Canchaya, C., C. Proux, G. Fournous, A. Bruttin, and H. Brussow. 2003. Prophage genomics. Microbiol Mol Biol Rev 67:238-76, table of contents.

13. Casas, V., and F. Rohwer. 2007. Phage metagenomics. Methods Enzymol 421:259-68.

14. Chang, K. H., F. S. Wen, T. T. Tseng, N. T. Lin, M. T. Yang, and Y. H. Tseng. 1998. Sequence analys is and expression of the filamentous phage phi Lf gene I encoding a $48-\mathrm{kDa}$ protein associated with host cell membrane. Biochem Biophys Res Commun 245:313-8.

15. da Silva Neto, J. F., T. Koide, S. L. Gomes, and M. V. Marques. 2007. The single extracytoplas mic-function sigma factor of Xylella fastidiosa is involved in the heat shock response and presents an unusual regulatory mechanism. J Bacteriol 189:551-60.

16. da Silva, V. S., C. S. Shida, F. B. Rodrigues, D. C. Ribeiro, A. A. de Souza, H. D. Coletta-Filho, M. A. Machado, L. R. Nunes, and R. C. de Oliveira. 2007. Comparative genomic characterization of citrus-associated Xylella fastidiosa strains. BMC Genomics 8:474

17. Davis, B. M., and M. K. Waldor. 2003. Filamentous phages linked to virulence of Vibrio cholerae. Curr Opin Microbiol 6:35-42.

18. Edgar, R., M. Domrachev, and A. E. Lash. 2002. Gene Expression Omnibus: NCBI gene expression and hybridization array data repository. Nucleic Acids Res 30:207-10.

19. Felsenstein, J. 2005. PHYLIP (Phylogeny Inference Package) version 3.6 . Distributed by the author, Department of Genome Sciences, University of Washington, Seattle. 
20. Grigoriev, A. 1998. Analyzing genomes with cumulative skew diagrams. Nucleic Acids Res 26:2286-90.

21. Grindley, N. D., K. L. Whiteson, and P. A. Rice. 2006. Mechanisms of sitespecific recombination. Annu Rev Biochem 75:567-605.

22. Groth, A. C., and M. P. Calos. 2004. Phage integrases: biology and applications. J Mol Biol 335:667-78.

23. Hacker, J., and J. B. Kaper. 2000. Pathogenicity is lands and the evolution of mic robes. Annu Rev Microbiol 54:641-79.

24. Hagemann, M., D. Hasse, and G. Berg. 2006. Detection of a phage genome carrying a zonula occludens like toxin gene (zot) in clinical isolates of Stenotrophomonas maltophilia. Arch Microbiol 185:449-58.

25. Hatfull, G. F., M. L. Pedulla, D. Jacobs-Sera, P. M. Cichon, A. Foley, M. E. Ford, R. M. Gonda, J. M. Houtz, A. J. Hryckowian, V. A. Kelchner, S. Namburi, K. V. Pajcini, M. G. Popovich, D. T. Schleicher, B. Z. Simanek, A. L. Smith, G. M. Zdanowicz, V. Kumar, C. L. Peebles, W. R. Jacobs, Jr., J. G. Lawrence, and R. W. Hendrix. 2006. Exploring the mycobacteriophage metaproteome: phage genomics as an educational platform. PLoS Genet 2:e92.

26. Hendrix, R. W. 2003. Bacteriophage genomics. Curr Opin Microbiol 6:50611.

27. Hendrix, R. W. 2002. Bacteriophages: evolution of the majority. Theor Popul Biol 61:471-80.

28. Holden, B. J., J. W. Pinney, S. C. Lovell, G. D. Amoutzias, and D. L. Robertson. 2007. An exploration of alternative visualisations of the basic helix-loop-helix protein interaction network. BMC Bioinformatics 8:289.

29. Jensen, R. B., and K. Gerdes. 1995. Programmed cell death in bacteria proteic plasmid stabilization systems. Mol Microbiol 17:205-10.

30. Koide, T., S. M. Salem-Izacc, S. L. Gomes, and R. Z. Vencio. 2006. SpotWhatR: a user-friendly microarray data analys is system. Genet Mol Res 5:93-107.

31. Koide, T., R. Z. Vencio, and S. L. Gomes. 2006. Global gene expression analys is of the heat shock response in the phytopathogen Xylella fastidiosa. J Bacteriol 188:5821-30.

32. Larkin, M. A., G. Blackshields, N. P. Brown, R. Chenna, P. A McGettigan, H. McWilliam, F. Valentin, I. M. Wallace, A. Wilm, R. Lopez, J. D. Thompson, T. J. Gibson, and D. G. Higgins. 2007. Clustal W and Clustal X version 2.0. Bioinformatics 23:2947-8.

33. Magnuson, R. D. 2007. Hypothetical functions of toxin-antitoxin systems. J Bacteriol 189:6089-92.

34. Manson, J. M., and M. S. Gilmore. 2006. Pathogenicity is land integrase cross-talk: a potential new tool for virulence modulation. Mol Microbiol 61:555-9.

35. Nakai, K., and P. Horton. 1999. PSORT: a program for detecting sorting signals in proteins and predicting their subcellular localization. Trends Biochem Sci 24:34-6.

36. Ohnishi, M., K. Kurokawa, and T. Hayashi. 2001. Diversification of Escherichia coli genomes: are bacteriophages the major contributors? Trends Mic robiol 9:481-5.

37. Overbeek, R., M. Fonstein, M. D'Souza, G. D. Pusch, and N. Maltsev. 1999. The use of gene clusters to infer functional coupling. Proc Natl Acad Sci U S A 96:2896-901.

38. Pallen, M. J., and B. W. Wren. 2007. Bacterial pathogenomics. Nature 449:835-42.

39. Pedulla, M. L., M. E. Ford, J. M. Houtz, T. Karthikeyan, C. Wadsworth J. A. Lewis, D. Jacobs-Sera, J. Falbo, J. Gross, N. R. Pannunzio, W. Brucker, V. Kumar, J. Kandasamy, L. Keenan, S. Bardarov, J. Kriakov, J. G. Lawrence, W. R. Jacobs, Jr., R. W. Hendrix, and G. F. Hatfull. 2003. Origins of highly mosaic mycobacteriophage genomes. Cell 113:17182.

40. Rice, P., I. Longden, and A. Bleasby. 2000. EMBOSS: the European Molecular Biology Open Software Suite. Trends Genet 16:276-7.

41. Saitou, N., and M. Nei. 1987 . The neighbor-joining method: a new method for reconstructing phylogenetic trees. Mol Biol Evol 4:406-25.

42. Simpson, A. J., F. C. Reinach, P. Arruda, F. A. Abreu, M. Acencio, R. Alvarenga, L. M. Alves, J. E. Araya, G. S. Baia, C. S. Baptista, M. H. Barros, E. D. Bonaccorsi, S. Bordin, J. M. Bove, M. R. Briones, M. R. Bueno, A. A. Camargo, L. E. Camargo, D. M. Carraro, H. Carrer, N. B. Colauto, C. Colombo, F. F. Costa, M. C. Costa, C. M. Costa-Neto, L. L. Coutinho, M. Cristofani, E. Dias-Neto, C. Docena, H. El-Dorry, A. P. Facincani, A. J. Ferreira, V. C. Ferreira, J. A. Ferro, J. S. Fraga, S. C. Franca, M. C. Franco, M. Frohme, L. R. Furlan, M. Garnier, G. H. Goldman, M. H. Goldman, S. L. Gomes, A. Gruber, P. L. Ho, J. D. Hoheisel, M. L. Junqueira, E. L. Kemper, J. P. Kitajima, J. E. Krieger, E. E. Kuramae, F. Laigret, M. R. Lambais, L. C. Leite, E. G. Lemos, M. V. Lemos, S. A. Lopes, C. R. Lopes, J. A. Machado, M. A. Machado, A. M. Madeira, H. M. Madeira, C. L. Marino, M. V. Marques, E. A. Martins, E. M. Martins, A. Y. Matsukuma, C. F. Menck, E. C. Miracca, C. Y. Miyaki, C. B. Monteriro-Vitorello, D. H. Moon, M. A. Nagai, A. L Nascimento, L. E. Netto, A. Nhani, Jr., F. G. Nobrega, L. R. Nunes, M. A. Oliveira, M. C. de Oliveira, R. C. de Oliveira, D. A. Palmieri, A. Paris, B. R. Peixoto, G. A. Pereira, H. A. Pereira, Jr., J. B. Pesquero, R. B. Quaggio, P. G. Roberto, V. Rodrigues, M. R. A. J. de, V. E. de Rosa, Jr.,
R. G. de Sa, R. V. Santelli, H. E. Sawasaki, A. C. da Silva, A. M. da Silva, F. R. da Silva, W. A. da Silva, Jr., J. F. da Silveira, et al. 2000. The genome sequence of the plant pathogen Xylella fastidiosa. The Xylella fastidiosa Consortium of the Organization for Nucleotide Sequencing and Analysis. Nature 406:151-9.

43. Tamura, K., J. Dudley, M. Nei, and S. Kumar. 2007. MEGA4: Molecular Evolutionary Genetics Analysis (MEGA) software version 4.0. Mol Biol Evol 24:1596-9.

44. Tatusov, R. L., M. Y. Galperin, D. A. Natale, and E. V. Koonin. 2000. The COG database: a tool for genome-scale analys is of protein functions and evolution. Nucleic Acids Res 28:33-6.

45. Tobe, T., S. A. Beatson, H. Taniguchi, H. Abe, C. M. Bailey, A. Fivian, R. Younis, S. Matthews, O. Marches, G. Frankel, T. Hayashi, and M. J. Pallen. 2006. An extensive repertoire of type III secretion effectors in Escherichia coli $\mathrm{O} 157$ and the role of lambdoid phages in their dissemination. Proc Natl Acad Sci U S A 103:14941-6.

46. Treangen, T. J., and X. Messeguer. 2006. M-GCAT: interactively and efficiently constructing large-scale multiple genome comparison frameworks in closely related species. BMC Bioinformatics 7:433.

47. Tusher, V. G., R. Tibshirani, and G. Chu. 2001. Signific ance analys is of microarrays applied to the ionizing radiation response. Proc Natl Acad Sci U S A 98:5116-21.

48. Van Sluys, M. A., M. C. de Oliveira, C. B. Monteiro-Vitorello, C. Y Miyaki, L. R. Furlan, L. E. Camargo, A. C. da Silva, D. H. Moon, M. A. Takita, E. G. Lemos, M. A. Machado, M. I. Ferro, F. R. da Silva, M. H. Goldman, G. H. Goldman, M. V. Lemos, H. El-Dorry, S. M. Tsai, H. Carrer, D. M. Carraro, R. C. de Oliveira, L. R. Nunes, W. J. Siqueira, L. L. Coutinho, E. T. Kimura, E. S. Ferro, R. Harakava, E. E. Kuramae, C. L. Marino, E. Giglioti, I. L. Abreu, L. M. Alves, A. M. do Amaral, G. S. Baia, S. R. Blanco, M. S. Brito, F. S. Cannavan, A. V. Celestino, A. F. da Cunha, R. C. Fenille, J. A. Ferro, E. F. Formighieri, L. T. Kishi, S. G. Leoni, A. R. Oliveira, V. E. Rosa, Jr., F. T. Sassaki, J. A. Sena, A. A. de Souza, D. Truffi, F. Tsukumo, G. M. Yanai, L. G. Zaros, E. L. Civerolo, A. J. Simpson, N. F. Almeida, Jr., J. C. Setubal, and J. P. Kitajima. 2003. Comparative analyses of the complete genome sequences of Pierce's disease and citrus variegated chlorosis strains of Xylella fastidiosa. J Bacteriol 185:1018-26

49. Williams, K. P. 2002. Integration sites for genetic elements in prokaryotic tRNA and tmRNA genes: sublocation preference of integrase subfamilies. Nucleic Acids Res 30:866-75.

50. Wommack, K. E., and R. R. Colwell. 2000. Virioplankton: viruses in aquatic ecosystems. Microbiol Mol Biol Rev 64:69-114.

\section{FIGURE LEGENDS}

Figure 1. Schematic chromosome alignment of the genomes of four Xylella fastidiosa strains, starting from their predicted origin of replication. The letters (A$\mathrm{M})$ depict the chromosome backbone, showing the relative position and size of collinear chromosome regions. Black triangles illus trate the position of prophagelike and GI regions; and white triangles illustrate the prophage remnants.

Figure 2. Analysis of up- and downstream regions of each phage predicted ORF among the four strains. Comparison of SNPs, INDELs and Identity between the prophage-like and phage remnants against the core genome.

Figure 3. Transmission - electron micrographs of Xylella fastidiosa in planta with phage-like particles inside and outside the cell.

Figure 4. Spring-embedded layout incorporating evolutionary distance and BLAST relationships informations. Nodes are automatically arranged so that the distance between proteins reflects their sequence divergence and placed into discrete clusters or "containers" corresponding to sub-families.

Figure 5. Phylogenetic reconstruction of phage and GI integrases against 132 homologues from bacterial phage elements. Xylella phage integrases and GI integrases are represented by black diamond-shaped symbols. Distance tree computed by the neighbor-joining method, using the JTT matrix-based method. Positions containing gaps and missing data were eliminated from the dataset.

Figure 6. Phylogenetic reconstruction of phage and GI integrases against 186 homologues from viruses. Xylella phage integrases and GI integrases are represented by black diamond-shaped symbols. Distance tree computed by the neighbor-joining method, using the JTT matrix-based method. Positions containing gaps and missing data were eliminated from the dataset. 
Table 01. General genomic features of each phage-related and island elements identified in the four strains of Xylella

\begin{tabular}{cccccc}
\hline \multicolumn{2}{c}{ Length (bp) } & \# ORFs & Integrase $^{\text {a }}$ & Associated tRNA & Status \\
\hline XF-CVC & & & & VAL & Probable complete \\
\hline xfp1 & 42,178 & 54 & (1) Full-length & PAL (frag) & Probable complete \\
xfp2 & 43,708 & 58 & (1) Full-length / (1) Fragment & V & Defective \\
xfp3 & 26,940 & 44 & (1) FS / SCF & ARG & Probable defective \\
xfp4 & 45,930 & 69 & (1) Full-length & CYS & Defective \\
\hline xfp5 & 18,184 & 31 & (1) FS / SCF & ASN & Probable complete \\
xfp6 & 43,585 & 57 & (1) Full-length & GLY & Genomic Island \\
giCVC & 67,058 & 78 & (1) Full-length / (2) Fragments & SER & Phage remnant \\
\hline cvc-r -1 & 14,946 & 8 & (1) Full-length & VAL & Phage remnant \\
\hline cvc-r -2 & 1,682 & 1 & (1) Fragment & LYS & Phage remnant \\
\hline cvc-r -3 & 6,919 & 13 & (1) Fragment & GLY & Phage remnant \\
\hline cvc-r -4 & 14,561 & 20 & (1) Full-length & LYS & Phage remnant \\
\hline cvc-r -5 & 16,819 & 22 & - &
\end{tabular}

\begin{tabular}{cccccc}
\hline XF-PD & & & & \\
\hline xpd1 & 55,498 & 76 & (2) Full-length / (1) Fragment & - & Probable complete \\
\hline xdp2 $*$ & 62,087 & 85 & (2) Full-length & - & Probable complete \\
\hline xpd3 & 13,911 & 22 & (1) Full-length & Probable defective \\
\hline xpd4 & 16,295 & 24 & (1) Full-length & LYS & Probable defective \\
\hline xpd5 & 24,192 & 41 & - & GLY & Defective \\
\hline xpd6 & 27,651 & 45 & (1) FS / SCF & VAL & Defective \\
\hline xpd7 & 17,795 & 29 & (1) FS / SCF & ASN & Defective \\
\hline xpd8 & 15,302 & 21 & (1) FS / SCF & CYS & Phage remnant \\
\hline pd-r-1 & 6,613 & 8 & (1) Full-length & VAL & Phage remnant \\
\hline pd-r-2 & 407 & 1 & (1) Fragment & &
\end{tabular}

\begin{tabular}{cccccc}
\hline XF-OLS & & & & & \\
\hline xop1 & 17,201 & 24 & - & - & Defective \\
\hline xop2 & 32,742 & 39 & (1) Full-length & Probable complete \\
\hline xop3 & 41,771 & 60 & (1) Full-length & Probable complete \\
\hline xop4 & 22,988 & 40 & (1) Full-length & Probable defective \\
\hline xop5 & 17,738 & 36 & (1) Full-length & Defective \\
\hline xop6 & 41,004 & 59 & (2) Full-length & THS & Probable complete \\
\hline xop7 & 38,303 & 63 & (1) FS / SCF / (1) Fragment & D & Defective \\
xop8 & 40,886 & 72 & (1) Full-length / (1) FS / SCF & VAL & Probable defective \\
\hline xop9 & 43,551 & 66 & (1) Full-length & GLY & Probable defective \\
xop10 & 32,915 & 65 & (1) Full-length & CYS & Phage remnant \\
\hline ol-r-1 & 10,484 & 7 & (1) FS / SCF & &
\end{tabular}

\begin{tabular}{cccccc}
\hline XF-ALS & & & & & \\
\hline xap1 & 41,622 & 62 & (1) Full-length / (1) Fragment & VAL (frag) & Probable complete \\
\hline xap2 & 22,978 & 29 & (1) Full-length & CYS & Probable defective \\
\hline xap3 & 48,027 & 76 & (1) Full-length & GLY & Probable complete \\
\hline xap4 & 20,150 & 32 & (2) Full-length & ASN (frag) & Probable defective \\
\hline xap5 & 37,661 & 59 & (1) Full-length / (1) Fragment & VAL & Probable complete \\
\hline xap6 & 39,002 & 54 & (1) Full-length & - & Probable complete \\
\hline xap7 & 26,309 & 42 & (1) Full-length & - & Probable complete \\
xap8 & 42,407 & 63 & - & VAL & Probable complete \\
xap9 & 45,251 & 73 & (1) Full-length / (1) FS /SCF & LYS (frag) & Defective \\
\hline xap10 & 18,200 & 27 & (1) Fragment & LYS & Defective \\
\hline xap11 & 14,923 & 21 & (1) Fragment & GLY & Phage remnant \\
\hline al-r-1 & 2,740 & 2 & (1) Fragment & SER & Phage remnant \\
\hline al-r-2 & 10,691 & 14 & (1) FS /SCF & Phage remnant \\
\hline al-r-3 & 8,536 & 10 & (1) Full-length &
\end{tabular}

${ }^{\mathrm{a}} \mathrm{FS} / \mathrm{SCF}=$ frameshift or stop codon in frame; ${ }^{\mathrm{b}}$ frag= fragment of tRNA

* XF-PD genomic island present inside xpd2

Table 02. Diversity of the Xf-CVC phages in six different strains of X. fastidiosa by hybridization study: four strains from CVC-affected plants (56a, $9.12 \mathrm{c}, 187 \mathrm{~b}$, and 36f), one from asymptomatic plant (CV21), and one from Pecosita-affected plant (Fb7), a CVC-similar disease. Presence is given in terms of number of copies of each ORF within the phages (data extracted from GEO database, accession number GSE8493).

\begin{tabular}{|c|c|c|c|c|c|c|}
\hline XF-CVC Element & $187 b$ & $36 f$ & $56 a$ & $9.12 \mathrm{c}$ & Cv21 & Fb7 \\
\hline xfp1 & Equal & Equal & Higher $(>50 \%)$ & Equal & Equal & Equal \\
\hline xfp2 & Equal & Equal & Higher $(>40 \%)$ & Higher $(>40 \%)$ & Equal & Equal \\
\hline xfp3 & Equal & Equal & Equal & Equal & Equal & Equal \\
\hline xfp5 & Higher $(>50 \%)$ & Higher $(>40 \%)$ & Higher $(>40 \%)$ & Higher $(>40 \%)$ & Higher $(>40 \%)$ & Equal \\
\hline xfp6 & Higher $(>50 \%)$ & Higher $(>40 \%)$ & Higher $(>50 \%)$ & Higher $(>50 \%)$ & Higher $(>50 \%)$ & Equal \\
\hline cve-r1 & Higher $(>50 \%)$ & Equal & Equal & Equal & Equal & Equal \\
\hline cve-r2 & Equal & Equal & Equal & Equal & Equal & Equal \\
\hline cve-r3 & Equal & Equal & Equal & Equal & Equal & Equal \\
\hline cve-r4 & Equal & Equal & Equal & Equal & Equal & Equal \\
\hline cve-r5 & Equal & Equal & Equal (50\% absents) & Equal (50\% absents) & Equal (30\% absents) & Equal \\
\hline
\end{tabular}


Table 03. List of phage-related genes with putative function assigned and differentially expressed under different heat shock conditions (at $40{ }^{\circ} \mathrm{C}$ ).

\begin{tabular}{|c|c|c|c|c|c|c|}
\hline $\begin{array}{c}\text { Prophage-like } \\
\text { Element }\end{array}$ & ORF ID & Product & $\begin{array}{l}\text { Expression } \\
\text { in 3G10R }{ }^{\text {a }}\end{array}$ & $\begin{array}{c}\text { Expression } \\
\text { at } 40^{\circ} \mathrm{C}^{\mathrm{b}}\end{array}$ & $\begin{array}{c}\text { Expression } \\
\text { at } 40^{\circ} \mathrm{C}^{\mathrm{c}}\end{array}$ & $\begin{array}{c}\text { Expression } \\
\text { at } 40^{\circ} \mathrm{C}^{\mathrm{d}}\end{array}$ \\
\hline xfp1 & $\begin{array}{l}\text { XF0678 } \\
\text { XF0684 } \\
\text { XF0685 } \\
\text { XF0686 } \\
\text { XF0704 } \\
\text { XF0717 } \\
\text { XF0718 } \\
\text { XF0719 }\end{array}$ & $\begin{array}{l}\text { phage-related integrase } \\
\text { phage-related antirepressor } \\
\text { phage-related protein P50 } \\
\text { phage-related protein P51 } \\
\text { phage-related antirepressor } \\
\text { phage-related minor tail protein } \\
\text { phage-related protein } \\
\text { phage-related baseplate assembly protein V }\end{array}$ & $\begin{array}{l}\uparrow \\
\uparrow \\
\uparrow\end{array}$ & $\begin{array}{l}\uparrow \\
\uparrow \\
\uparrow \\
\uparrow \\
\uparrow \\
\uparrow \\
\uparrow \\
\uparrow\end{array}$ & $\begin{array}{l}\uparrow \\
\uparrow \\
\uparrow \\
\uparrow\end{array}$ & $\uparrow$ \\
\hline xfp2 & $\begin{array}{l}\text { XF2488 } \\
\text { XF2491 } \\
\text { XF2492 } \\
\text { XF2494 } \\
\text { XF2495 } \\
\text { XF2496 } \\
\text { XF2511 } \\
\text { XF2522 } \\
\text { XF2523 } \\
\text { XF2525 } \\
\text { XF2526 }\end{array}$ & $\begin{array}{l}\text { phage-related baseplate assembly protein } \mathrm{J} \\
\text { HTH-type transcriptional regulator } \\
\text { phage-realted baseplate assembly protein V } \\
\text { phage-related minor tail protein } \\
\text { phage-related protein } \\
\text { phage-related protein } \\
\text { phage-related repressor protein CI } \\
\text { phage-related putative protein P51 } \\
\text { phage-related putative protein P50 } \\
\text { phage-related DNA polymerase (P45) } \\
\text { phage-related putative protein P44 }\end{array}$ & $\uparrow$ & $\begin{array}{l}\uparrow \\
\uparrow \\
\downarrow \\
\uparrow \\
\uparrow \\
\uparrow \\
\downarrow\end{array}$ & $\begin{array}{l}\uparrow \\
\uparrow \\
\uparrow \\
\uparrow \\
\uparrow \\
\downarrow \\
\uparrow \\
\uparrow\end{array}$ & $\downarrow$ \\
\hline xfp3 & $\begin{array}{l}\text { XF1559 } \\
\text { XF1588 } \\
\text { XF1590 } \\
\text { XF1598 } \\
\text { XF1599 }\end{array}$ & $\begin{array}{l}\text { phage-related regulatory protein (antirepressor) } \\
\text { Virulence-associated protein } \\
\text { plasmid stabilization protein } \\
\text { phage-related protein } \\
\text { phage-related tail fiber protein }\end{array}$ & $\uparrow$ & $\begin{array}{l}\uparrow \\
\downarrow \\
\uparrow\end{array}$ & $\downarrow$ & \\
\hline xfp4 & $\begin{array}{l}\text { XF1644 } \\
\text { XF1645 } \\
\text { XF1647 } \\
\text { XF1663 } \\
\text { XF1668 } \\
\text { XF1686 } \\
\text { XF1687 } \\
\text { XF1696 } \\
\text { XF1703 } \\
\text { XF1706 } \\
\text { XF1710 }\end{array}$ & $\begin{array}{l}\text { Single-stranded DNA-binding protein } \\
\text { phage-related antirepressor } \\
\text { phage-related protein } \\
\text { phage-related antirepressor } \\
\text { HicB-related protein } \\
\text { phage-related protein } \\
\text { phage-related protein } \\
\text { Anti-toxin RelB protein } \\
\text { phage-related addiction module killer protein } \\
\text { phage-related long tail fiber protein } \\
\text { transcriptional regulator }\end{array}$ & $\begin{array}{l}\uparrow \\
\uparrow \\
\uparrow\end{array}$ & $\begin{array}{l}\uparrow \\
\uparrow \\
\uparrow \\
\uparrow \\
\uparrow \\
\uparrow\end{array}$ & $\begin{array}{l}\uparrow \\
\uparrow \\
\uparrow \\
\uparrow\end{array}$ & \\
\hline xfp5 & $\begin{array}{l}\text { XF2110 } \\
\text { XF2115 } \\
\text { XF2120 } \\
\text { XF2121 } \\
\text { XF2122 } \\
\text { XF2129 }\end{array}$ & $\begin{array}{l}\text { DNA binding transcriptional regulator } \\
\text { phage-related protein } \\
\text { phage-related terminase protein } \\
\text { virulence-associated protein E } \\
\text { DNA primase } \\
\text { phage-related protein }\end{array}$ & $\begin{array}{l}\downarrow \\
\uparrow \\
\uparrow \\
\uparrow\end{array}$ & $\uparrow$ & & $\downarrow$ \\
\hline xfp6 & $\begin{array}{l}\text { XF0480 } \\
\text { XF0483 } \\
\text { XF0487 } \\
\text { XF0512 } \\
\text { XF0535 }\end{array}$ & $\begin{array}{l}\text { phage-related integrase } \\
\text { phage-related protein } \\
\text { Tfp pilus assembly protein, major pilin } \\
\text { FimA/PilA } \\
\text { phage-related protein } \\
\text { Transposase, IS200/IS605 family }\end{array}$ & $\begin{array}{l}\uparrow \\
\uparrow \\
\downarrow \\
\downarrow\end{array}$ & $\uparrow$ & & \\
\hline cve-r3 & XF2761 & phage-related integrase (fragment) & & $\uparrow$ & & \\
\hline cvc-r4 & $\begin{array}{l}\text { XF2298 } \\
\text { XF2302 } \\
\text { XF2305 }\end{array}$ & $\begin{array}{l}\text { Phosphotyrosine protein phosphatase } \\
\text { Glutamate-1-semialdehyde 2,1-aminomutase } \\
\text { Glyoxalase-like protein }\end{array}$ & $\downarrow$ & & $\begin{array}{l}\downarrow \\
\downarrow\end{array}$ & \\
\hline cve-r5 & $\begin{array}{l}\text { XF1859 } \\
\text { XF1864 } \\
\text { XF1869 }\end{array}$ & $\begin{array}{l}\text { Phage-related replication protein rstA } \\
\text { phage-related protein } \\
\text { phage-related protein }\end{array}$ & $\begin{array}{l}\uparrow \\
\uparrow\end{array}$ & $\uparrow$ & $\begin{array}{l}\uparrow \\
\uparrow\end{array}$ & \\
\hline
\end{tabular}

${ }^{\text {a }}$ Expression under different medium growth conditions (3G10R against PW) (data extracted from GEO database, accession number GSE6619).

${ }^{\mathbf{b}}$ Expression under heat shock response, at $40^{\circ} \mathrm{C}$, when compared against normal conditions of temperature $\left(25^{\circ} \mathrm{C}\right)($ data extracted from $\mathrm{Koide}$ et al, 2006a, from GEO database, accession number GSE4161).

${ }^{\mathbf{c}}$ Expression under heat shock response, at $40^{\circ} \mathrm{C}$, when compared against normal conditions of temperature $\left(29^{\circ} \mathrm{C}\right)(\mathrm{data}$ extracted from $\mathrm{Koide}$ et al, 2006b, from GEO database, accession number GSE3044).

${ }^{\text {d }}$ Expression under heat shock response of mutant strain (rpoE) of the strain $\mathrm{J} 1 \mathrm{a} 12$ (against $9 \mathrm{a} 5 \mathrm{c}$ array), under heat shock response, a $40{ }^{\circ} \mathrm{C}$, when compared against normal conditions of temperature $\left(25^{\circ} \mathrm{C}\right)$ (data extracted from da Silva Neto et al, 2007, from GEO database, accession number, GSE4960). 
Figure 1

Strain 9a5c (CVC)

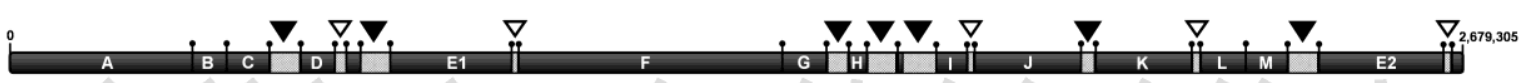

Strain Temecula1 (PD)

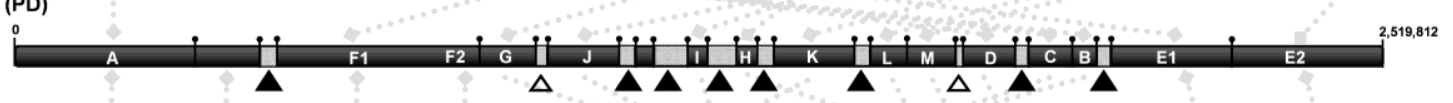

Strain Ann1 (OLS) Candidate Molecule

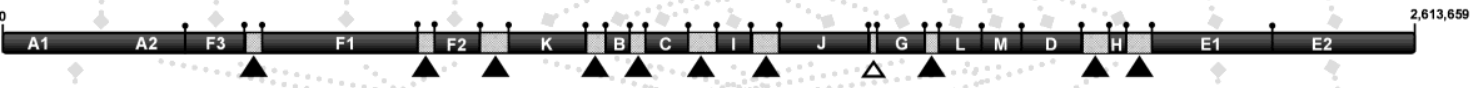

Strain Dixon (ALS)

Candidate Molecule

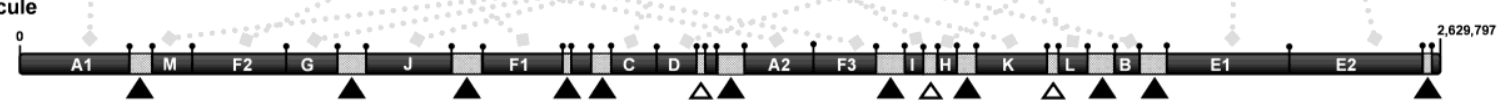

Figure 2

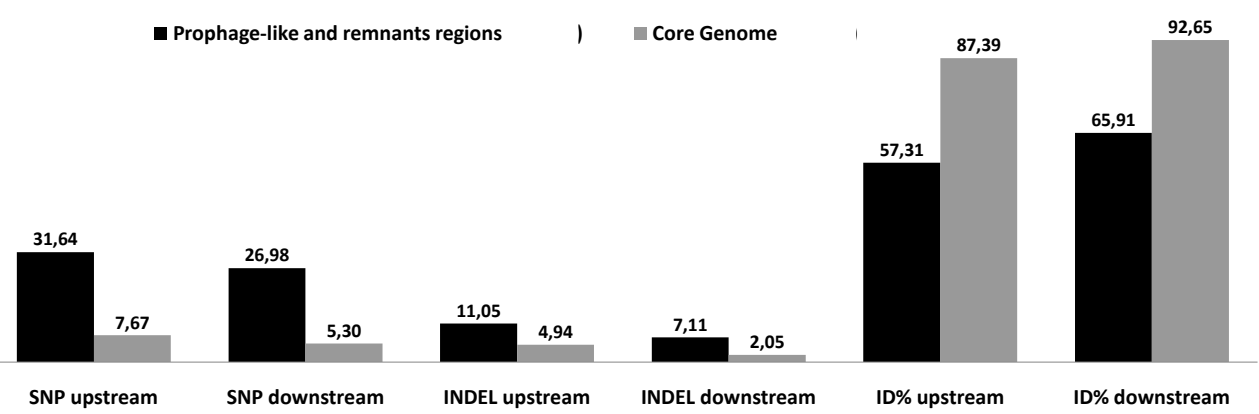

Figure 3

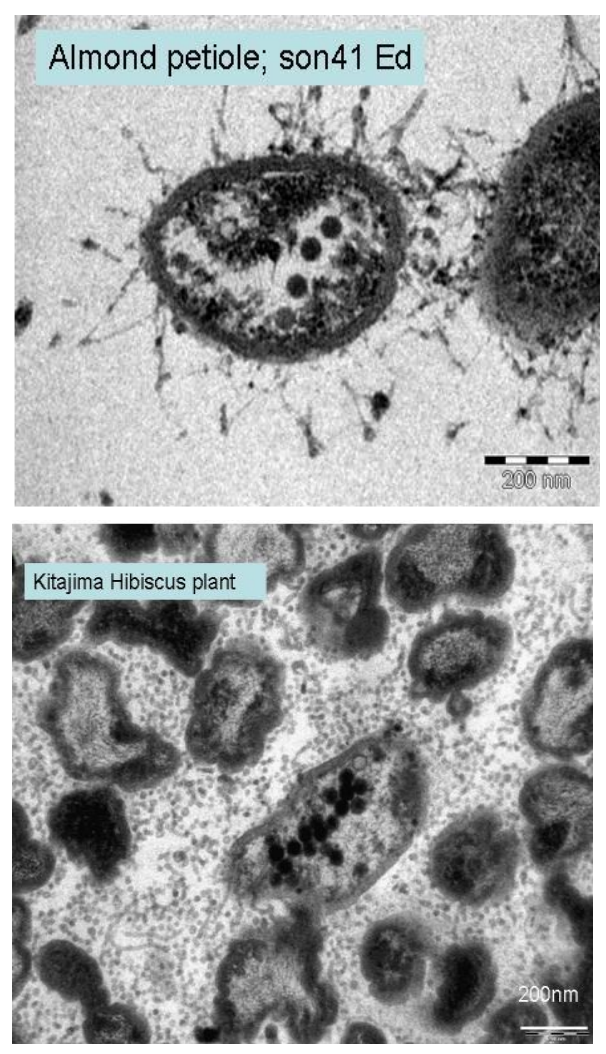


Figure 4

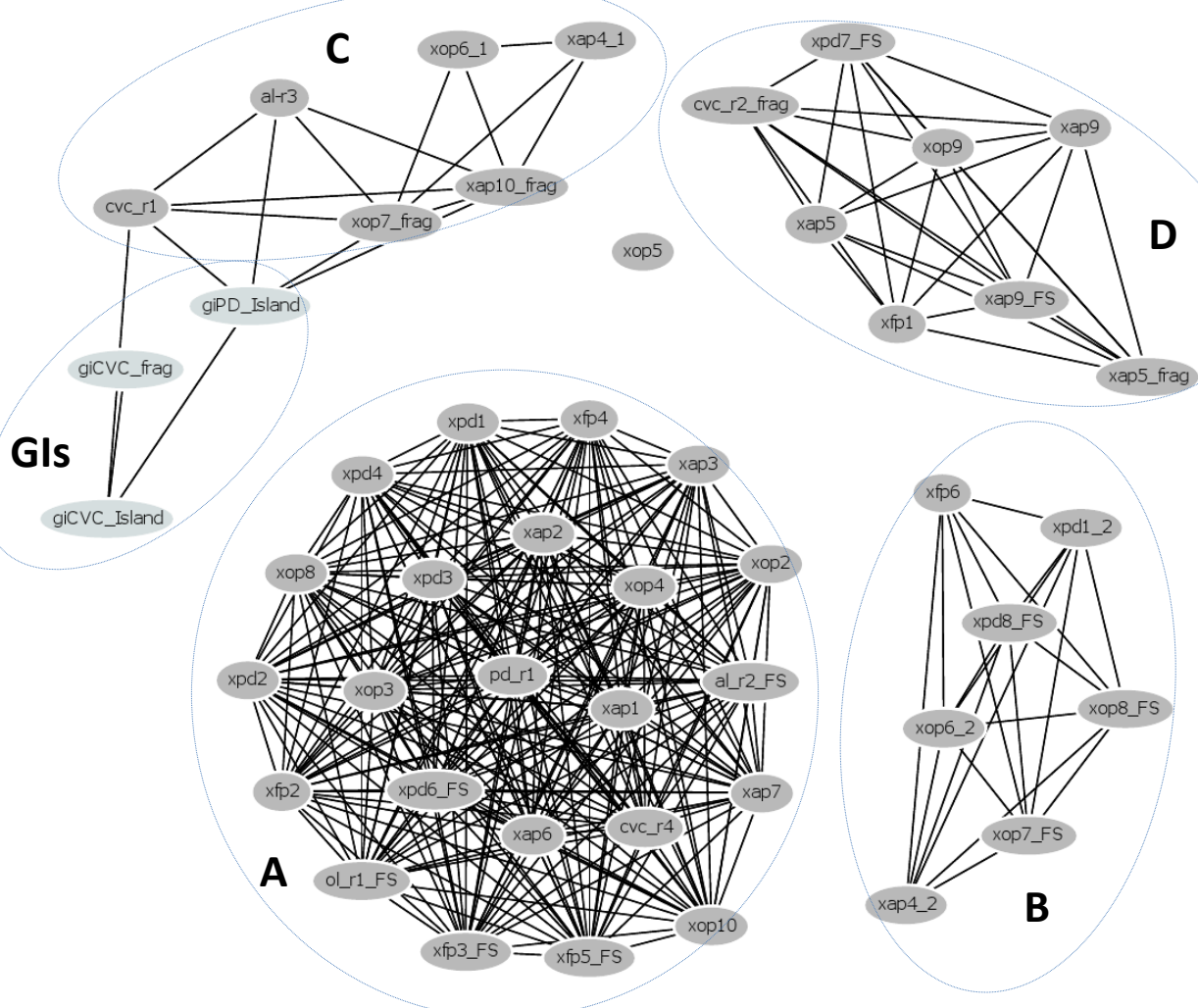

Figure 5

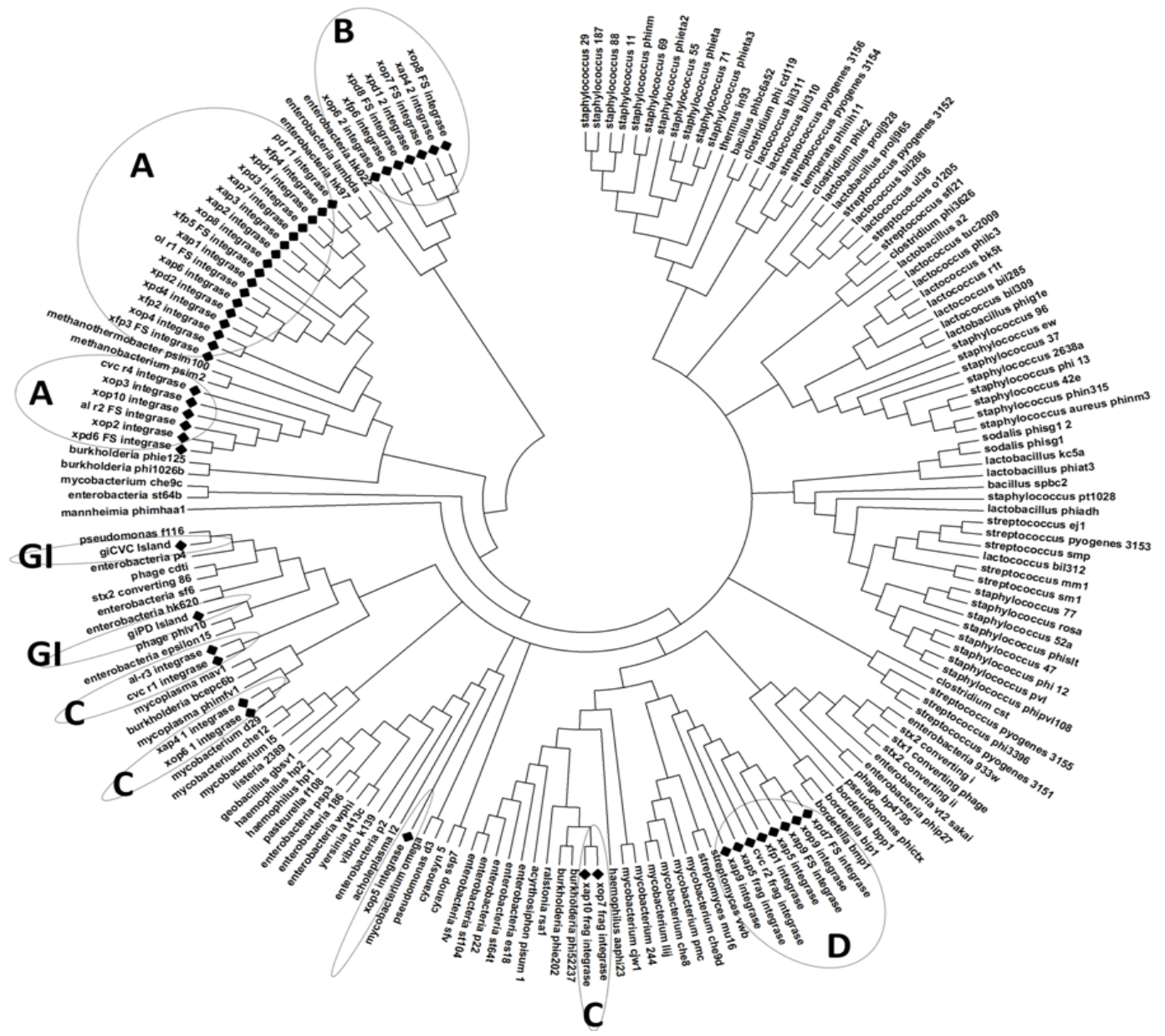


Figure 6

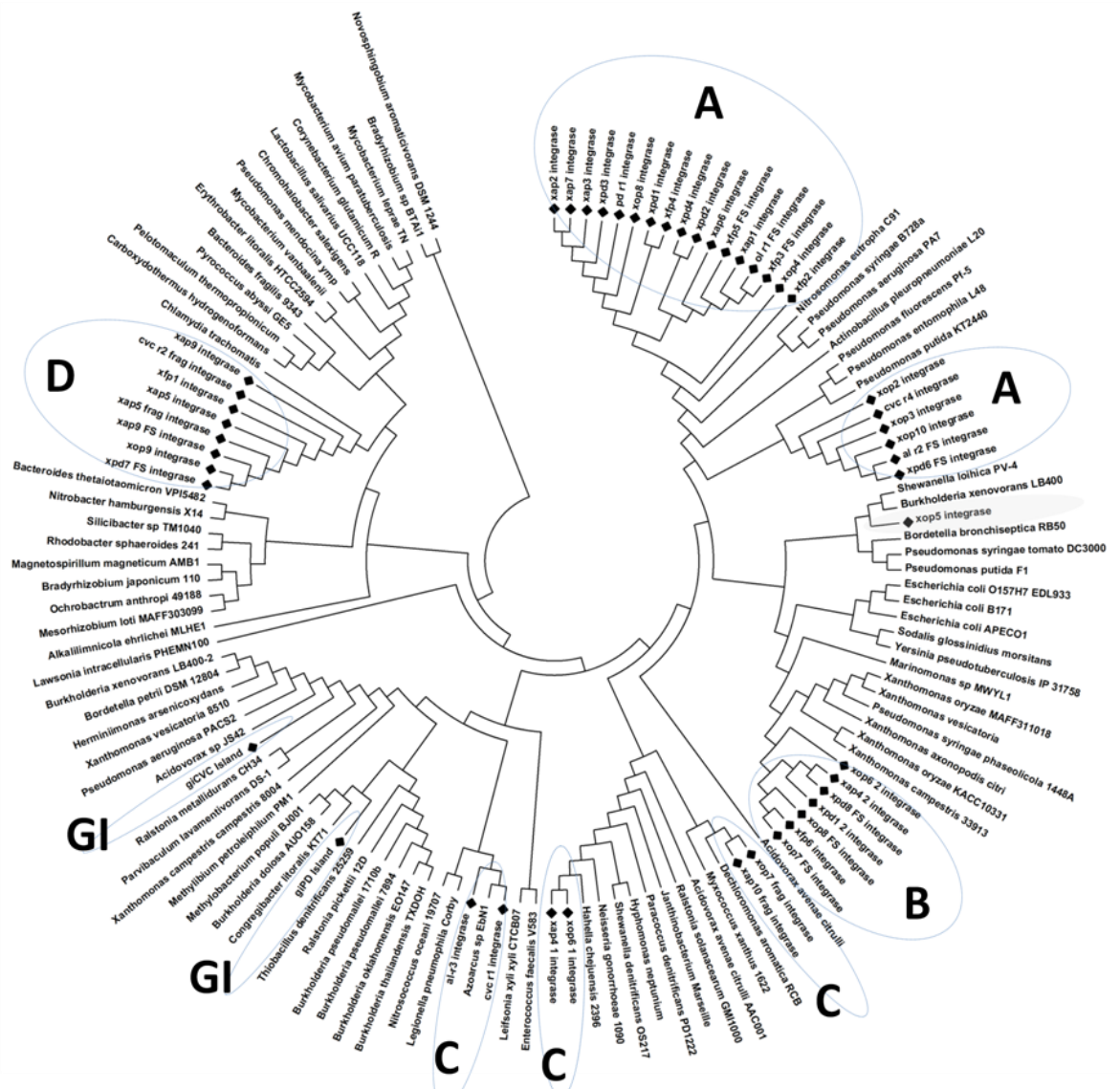

